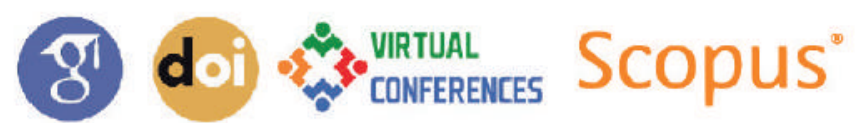
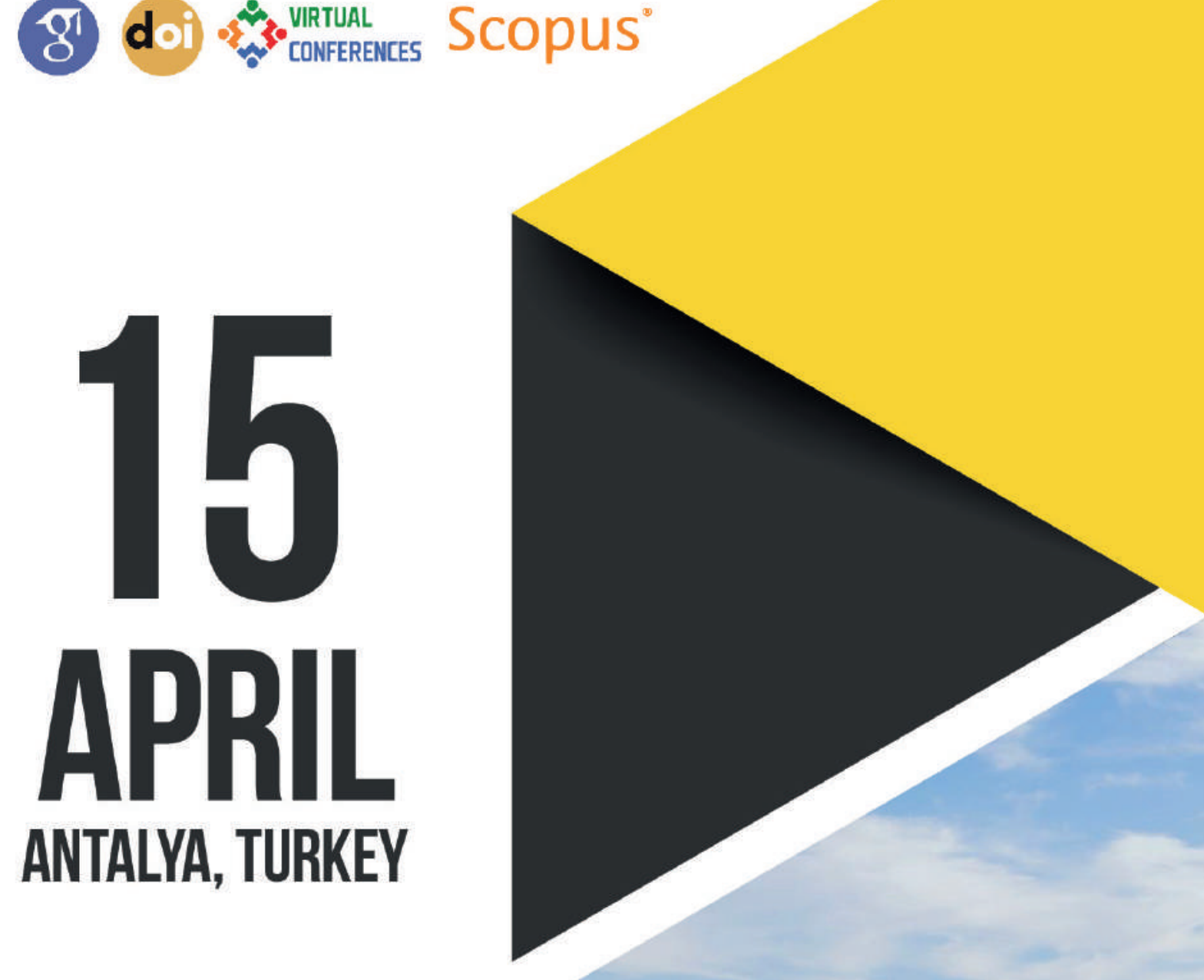

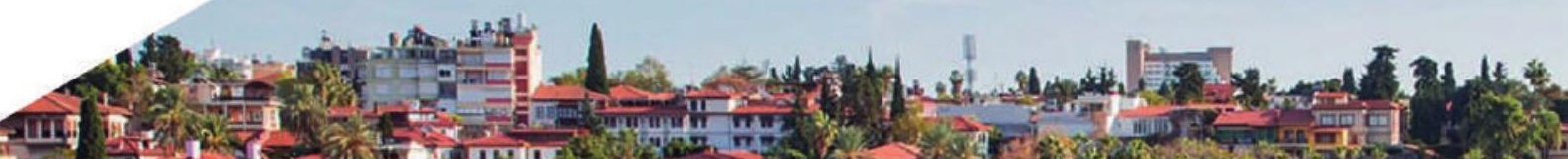

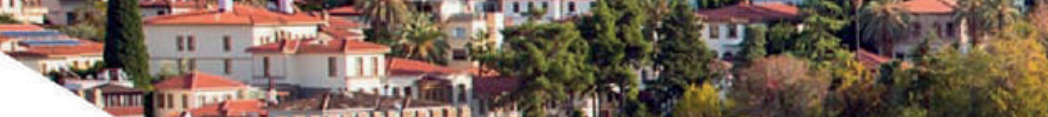




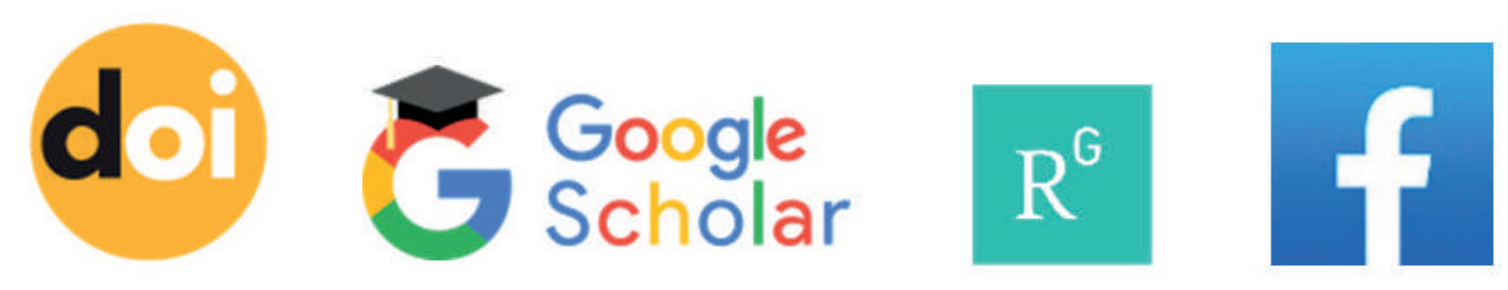

SCIENTIFIC PUBLISHING CENTER VIRTUALCONFERENCES.PRESS

INTERNATIONAL CONFERENCE SCIENCE AND EDUCATION/ULUSLARARASI KONFERANS BILIM VE EĞITIM

APRIL 2021

ANTALYA, TURKEY 


\title{
INTERNATIONAL CONFERENCE SCIENCE AND EDUCATION/ ULUSLARARASI KONFERANS BILIM VE EĞITIM
}

\begin{abstract}
APRIL 2021
ANTALYA, TURKEY

Editorial board/ Yayın Kurulu

Prof. Hakan Mete Dogan. Tokat Gaziosmanpasha University, Turkey

Prof. Afsun Sujayev, Institute of Additive Chemistry of the ANAS, Azerbaijan

Prof. Nadir Mammadli, Azerbaijan Architecture and Construction University, Azerbaijan

Prof. Munevver Sokmen, Konya Food and Agriculture University, Turkey

Assos. Prof. Ali Alkan, Karadeniz Technical University, Turkey

Assos.Prof. Ahmet Demirak, Mugla Sitki Kocman University, Turkey

The publisher is not responsible for the materials published in the collection. All materials are submitted in the author's edition and reflect the personal position of the conference participant.

Contact information of the organizing committee of the conference:

Email: info@virtualconferences.press

Official site: www.virtualconferences.press

DOI http://doi.org/10.37057/T_1

Available at virtualconferences.press
\end{abstract}




\section{BIOLOGY}

Iskandarova Dilfuza, Shodmonova Aziza 9

SCUTELLARIAL GROUP USED IN MEDICINE MEDICINAL PROPERTIES AND

DISTRIBUTION OF TYPES.

Muminova Guyoxon Alijanovna

TO STUDY THE NEUROPROTECTIVE EFFECT IN THE CORRECTION OF

CHANGES IN THE BRAIN IN EXPERIMENTAL HYPOTHYROIDISM

\section{CULTURLOGY}

Джабборов Мухаммаджон, Рахматов М.Г.

ПЕРИОД РЕКОНСТРУКЦИИ И ВОССТАНОВЛЕНИЯ ИСТОРИИ НАШЕГО НАРОДА В

ГОДЫ НЕЗАВИСИМОСТИ.

Нусратова Шоира Иватовна

БАДИИЙ АСАР ТАЪЛИМДА - ЖАМИЯТНИ МАЪНАВИЙ РИВОЖЛАНИШИНИНГ

МУХИМ ОМИЛИ СИФАТИДА

Хўжаев Дониёр

ЎСМИР БОКСЧИЛАРНИНГ ПСИХОЛОГИК ТАЙЁРГАРЛИГИ ҒАЛАБА ГАРОВИ

\section{ECONOMY}

Yuldosheva Inoyat Zikriyayevna., Toxirov Shohrux Janobil o'g'li

O'ZBEKISTON ERKIN IQTISODIY ZONALARIGA XITOY INVESTITSIYALARINI JALB

ETISHNING ASOSIY YO'NALISHLARI (“JIZZAX” EIZ MISOLIDA) ................................ 20

Yuldosheva Inoyat Zikriyayevna., Toshboltayeva Yulduz Abduqodir qizi

IQTISODIYOTDA INNOVATSIYANING TUTGAN O`RNI......

Yuldosheva Inoyat Zikriyayevna., Xaytqulova Zulayxo Mirzaboy qizi.

MILLIY IQTISODIYOTINING RAQOBATBARDOSHLIGINI OSHIRISHDA XORIJIY

INVESTITSIYALARNING O`RNI

\section{HISTORY}

Ахмедов Сайқал Абдурохмонович

АБУ БАРАКОТ НАСАФИЙ БУЮК ХАНАФИЙ ФАҚИХИ

Дилмурод Холлиев, Рахматова Дилбар

ТУРКИСТОНДА КЎРБОШИЛАРИ ФАОЛИЯТИ ВА УЛАРНИНГ КЕЙИНГИ ТАКДИРИ. 29

Тоштемиров Достон Дилшод ўғли

ЎЗБЕКИСТОН РЕСПУБЛИКАСИ ОЛИЙ ТАЬЛИМ ТИЗИМИНИ ИСЛОХ ҚИЛИШДА

ТЕМПУС ДАСТУРИНИНГ ИШТИРОКИ. 31

\section{LITERATURE}

Axmedova Mashhuraxon Ulug'bek qizi

MUQIMIY “SAYOHATNOMA”SIDA KELTIRILGAN QISHLOQLAR BILAN QISQACHA

TANISHUV

Доронина Ирина Николаевна, Акбарова Феруза Набиевна

ВЫРАЗИТЕЛЬНОЕ ЧТЕНИЕ КАК ОСОБАЯ ФОРМА ФОРМИРОВАНИЯ КОММУНИКА-

ТИВНОЙ КУЛЬТУРЫ. 


\section{MEDICINE}

Iriskulova EImira Uraimkulovna

DIAGNOSTIC EFFICIENCY OF ELASTOGRAPHY IN PATIENTS WITH PAROTID

GLAND TUMORS

Muhsimova N.R.

PSORIATIK ARTRITDA ALKOGOLSIZ YOGLI JIGAR KASALLIGINING ROLI VA

DAVOLASHNI TAKOMILLASHTIRISH USULLARI.

А.С. Алимов, Р.Х. Рахимов, У.С. Алимов

ПРОФИЛАКТИКА И ЛЕЧЕНИЕ КОРОНОВИРУСНОЙ ИНФЕКЦИИ COVID-19 В

АМБУЛАТОРНЫХ УСЛОВИЯХ С ИСПОЛЬЗОВАНИЕМ ИНФРАКРАСНОЙ

РЕЗОНАНСНОЙ ТЕРАПИИ

Касимова М.Б.

ЧАСТОТА ВСТРЕЧАЕМОСТИ ПАРАЗИТОЗОВ СРЕДИ ДЕТЕЙ С БРОНХИАЛЬНОЙ

АСТМОЙ

М.У. Турсунова, К.Т. Бобоев, Д.С. Маткаримова

ВЫЯВЛЕНИЕ ПОЛИМОРФИЗМА ГЕНА IL10 G-1082A (RS3024491) У БОЛЬНЫХ С

ЯЗВЕННОЙ БОЛЕЗНЬЮ В УЗБЕКСКОЙ ПОПУЛЯЦИИ.

Мамадалиева Яшнар Салиевна, Хушназаров Хасан Холикович,

Абдукодирова Махфуза Ботировна

РОЛЬ И ЗНАЧЕНИЕ ДИАГНОСТИКА ЛОКАЛЬНЫХ ФОРМ РАКА ПРЕДСТАТЕЛЬНОЙ

ЖЕЛЕЗЫ С ИСПОЛЬЗОВАНИЕМ СОВРЕМЕННЫХ ТЕХНОЛОГИЙ

ТРАНСРЕКТАЛЬНОГО УЛЬТРАЗВУКОВОГО ИССЛЕДОВАНИЯ

Муродова М.К., Сафаров М.Т., Нарзиев И.К.

ОПТИМИЗАЦИЯ ЛЕЧЕНИЯ КЛИНОВИДНЫХ ДЕФЕКТОВ ТВЁРДЫХ ТКАНЕЙ

ЗУБОВ У БЕРЕМЕННЫХ ЖЕНЩИН.

Ризамухамедова М.3., Ширанова Ш.Ш.

ЮРАКНИНГ РЕВМАТИК КАСАЛЛИГИДА ТЕРАПЕВТИК ТАКТИКА ВА

ПРОФИЛАКТИК ЁНДОШУВЛАР САМАРАДОРЛИГИНИ ОШИРИШ ЙЎЛЛАРИ.

Ташматова Гулноза Аълоевна

ОСОБЕННОСТИ КЛИНИЧЕСКИХ И ЛАБОРАТОРНЫХ ИССЛЕДОВАНИЙ ПРИ

БРОНХИАЛЬНОЙ АСТМЕ У ДЕТЕЙ ПЕРЕНЕСШИХ COVID - 19 54

\section{PEDAGOGY}

Azizov Solijon Uchmas o'g'li

BASIC STRATEGIES OF BLENDED LEARNING IN THE MODERNIZATION OF THE

SYSTEM OF PHILOLOGICAL HIGHER EDUCATION IN UZBEKISTAN .55

D.B. Mamadjanova

EDUCATIONAL VALUE OF "SORROWS OF TURKESTAN" BY ALIKHANTORA

SOGUNI

Gulchehra Rahmanova, Mavluda Uliqova

DIFFICULTIES OF TRANSLATING IDIOMS AND PHRASEOLOGICAL UNITS

Hayitova Iroda Ilhomovna

DIDACTIC OPPORTUNITIES OF DISTANCE LEARNING TECHNOLOGIES IN THE

ORGANIZATION OF INDEPENDENT EDUCATIONAL ACTIVITIES OF STUDENTS

Karimova Gavkhar Qudratilla qizi, Urakboyeva Ganjina Khairulla qizi

CHARACTERISTICS OF PATRIOTIC EDUCATION OF YOUNG PEOPLE

Khasanov Abdushokhid Abdurashidovich, Urokova Sharofat Bakhodir qizi

USE OF ELECTRONIC EDUCATION RESOURCES IN THE LEARNING PROCESS.

Rasulova Nasibakhon Yusufjonovna

ADAPTIVE LEARNING SYSTEM USING FUZZY LOGIC

Rasulova Zilola Durdimurotovna

TECHNOLOGIES FOR THE DEVELOPMENT OF STUDENTS CREATIVE COMPETENCE

IN PROFESSIONAL ACTIVITY 
Байбаева Мухайё Худайбергеновна

РАХБАР ХОДИМЛАРНИ КОММУНИКАТИВ КОМПЕТЕНТЛИГИНИ

РИВОЖЛАНТИРИШ ОМИЛИ ...

Г.В.Елдашева

МАСОФАВИЙ МАЛАКА ОШИРИШ ТИЗИМИ ВА УНИНГ ТАРКИБИЙ ҚИСМЛАРИ.. 73

Дилмурадова Нилуфар Асатуллаевна

РОЛЬ ИНФОРМАЦИОНОННЫХ ТЕХНОЛОГИЙ КАК СРЕДСТВА ИНОСТРАННЫМ

ЯЗЫКАМ

Мирзаева Фарохат Одилжоновна

БЎЛАЖАК ЎКИТУВЧИЛАР ЖАМОАСИДАГИ ЎЗАРО МУНОСАБАТЛАРНИ

РИВОЖЛАНТИРИШГА ТАЪСИР ЭТУВЧИ ОМИЛЛАР

Муминова Дилнавоз Комиловна

ПУТИ ПОВЫШЕНИЯ ЭФФЕКТИВНОСТИ ПРЕПОДАВАНИЯ СПЕЦИАЛЬНЫХ

ДИСЦИПЛИН

Муратов Эльвин Ильич

РАЗВИТИЕ ИНФОРМАЦИОННЫХ КОМПЕТЕНЦИЙ У БУДУЩИХ УЧИТЕЛЕЙ.

Нодира Мелибоевна Эгамбердиева, Хуршида Ходжиакбаровна Сайдивалиева

ЎЗБЕКИСТОНДА ОИЛАЛАРНИНГ БАХТЛИЛИК ИНДЕКСИНИ БЕЛГИЛАШ:

ХОРИЖИЙ ТАЖРИБА

Умрихина В.И.

ДУХОВНЫЕ И НАЦИОНАЛЬНЫЕ ОСОБЕННОСТИ ПОДГОТОВКИ МОЛОДЕЖИ К

САМОСТОЯТЕЛЬНОЙ ЖИЗНИ В СЕМЬЕ.

Урумбаева Айгуль Нагметовна

НРАВСТВЕННОЕ ВОСПИТАНИЕ КАК ОСНОВА РАЗВИТИЯ ГАРМОНИЧНОЙ

ЛИЧНОСТИ.

Хайдаров Усмон Амиркулович

МАКТАБ ЎҚУВЧИЛАРИДА ТАРИХИЙ ТАФАККУРНИ РИВОЖЛАНТИРИШ

Шаумарова Зилола Абдушукуровна

СОЦИАЛЬНО-ПЕДАГОГИЧЕСКИЕ ОСОБЕННОСТИ ФОРМИРОВАНИЯ ЛИЧНОСТИ

РЕБЕНКА В НЕПОЛНОЙ СЕМЬЕ

\section{PHILOLOGY}

Bozorova Muborak Sharapovna

THE EFFECTIVE USE OF INNOVATIVE TECHNOLOGIES IN TEACHING FOREIGN LANGUAGES

Dildorakhon Nasirdinova

TEACHING TEXT TYPES:"THE LAST LEAF” BY HENRY (BLOOM'S CUBE AND

PRESS FORMULA)

Ivliyeva Galina Gafurovna

THE MOST EFFECTIVE WAYS OF IMPROVING FOREIGN VOCABULARY

Jumaniyozova N.A

APPROACHES TO THE STUDY OF LEGAL DISCOURSE IN LINGUISTICS

Khalilova Himoyat Khatamovna

INNOVATIVE TECHNIQUES OF TEACHING ENGLISH TO NON-LINGUISTIC

UNIVERSITY STUDENTS.

Mukhabbat Mamadjanovna Kurbanova, Toshmurotov Umidjon Baydulla o' $\mathbf{g}^{\mathbf{6}} \mathrm{li}$

THE USE OF INTERACTIVE TECHNOLOGIES IN TEACHING ENGLISH TO PART-TIME

STUDENTS

Nigmatova Dilsoz Yadgarovna

SOME FEATURES OF TEACHING SPECIAL VOCABULARY FOR NON-LINGUISTIC

STUDENTS

Nurboboeva Asila Kenjayor qizi, Holiqova Husnora

PARENTAL RESPONSIBILITY OF A CHILD. 
Nuritdinova Rayhona Numonovna

LECTURER AT THE DEPARTMENT OF UZBEK LANGUAGE AND LITERATURE

Rajapova Malika Ahmadali qizi, Hamdamova Mohidil To'xtasinovna

PRINCIPLES OF COGNITIVE METAPHOR AND ALLEGORY IN DISCOURSE.

Sattorova M

CHET TILLARINI O`QITISHDA ZAMONAVIY TEXNOLOGIYALAR.

Shodmonbekova K

CHET TILLARNI O`QITISHDA INNOVATSION TEXNOLOGIYALARDAN

FOYDALANISH

Sobirova Dilnoza Rasulovna

TIBBIY REKLAMA MATNLARIDA MOTIVLAR

Абдурахимова Шахноза Абдурашитовна, Рахимкулиева Гуласал Матчановна

ТАЪЛИМДА “CASE-STUDY” ТЕХНОЛОГИЯСИДАН ФОЙДАЛАНИШ ВА УНИНГ

АХАМИЯТИ

Бурнашев Ринат Фаритович, Нематуллаева Нилуфар Баходировна,

Худоярова Парвина Нодиржоновна

РОЛЬ ЛИНГВИСТИЧЕСКИХ КОРПУСОВ В НАУЧНЫХ ИССЛЕДОВАНИЯХ

Жумаева $\Gamma$

ИНОСТРАННЫЕ ЯЗЫКИ И ИСПОЛЬЗОВАНИЕ ИНФОРМАЦИОННЫХ

ТЕХНОЛОГИЙ В ИХ ОБУЧЕНИИ

Киличов Назарбай Раджапбаевич, Каримова Дилфуза

ҚАДИМГИ ТУРКИЙ ТИЛДАГИ АRЇ ЛЕКСЕМАСИНИНГ ХОЗИРГИ ТУРКИЙ ТИЛЛАР-

ГА МУНОСАБАТИ.

Махмудова Садоқат Холматовна

САИД АХМАД ХИКОЯЛАРИДА МИЛЛИЙ МАДАНИЯТ ТАЛҚИНИ

Мирханова Гуландом Рустамовна

РУС ТИЛШУНОСЛИГИДА СИНОНИМ ЛУҒАТЛАРНИНГ ШАКЛЛАНИШ

БОСКИЧЛАРИ

Шоазизова Азиза

ОСНОВНЫЕ ИНТЕРАКТИВНЫЕ ТЕХНОЛОГИИ ОБУЧЕНИЯ ИНОСТРАННОМУ

ЯЗЫКУ

\section{PSIXOLOGY}

Ernazarova Shahnoza Nizomiddin qizi, Avalova Kamola Sobirovna,

Urisheva Mohira Ibrohim qizi

OTA - ONALARDA TARBIYAVIY BILIMLARNI SHAKLLANTIRISH VOSITALARIDA

PSIXOLOGIK TAVSIFLANISHI

Yusupov Bakhadir, Jumoboyev Dilshod, Yusupova Hurliman

ОСОБЕННОСТИ ПРОЯВЛЕНИЯ СТРЕССА И ЕГО ПРОФИЛАКТИКА У СТУДЕНТОВ

ВО ВРЕМЯ СДАЧИ ЭКЗАМЕНАЦИОННОЙ СЕССИИ.

И.Х. Калонов

ИЖТИМОИЙ МУНОСАБАТЛАРДА САМАРАЛИ МУЛОКОТГА ЭРИШИШНИНГ

ПСИХОЛОГИК МЕХАНИЗМЛАРИ

Хакимова Ирода Мухаммаджоновна

ПСИХОЭМОЦИОНАЛЬНЫЕ АСПЕКТЫ ВОЗДЕЙСТВИЯ СТРЕССА НА

ЧЕЛОВЕКА И ЕГО РАЦИОНАЛИЗАЦИЯ

\section{AGRICULTURE}

Ф.А.Мустафакулова, С.Н.Мирзаабдуллаева

BACILLUS THURINGIENSIS-ЭКОЛОГИК ПРЕПАРАТ . 147 


\section{STATE AND LAW}

Ismailov Bakhodir Islamovich, Inoyatullaev Sadullajon Khabibullaevich ENSURING INEVITABILITY OF LIABILITY FOR CORRUPTION OFFENSES IN THE REPUBLIC OF UZBEKISTAN.

Raxmonqulov Shoxrux Akram o'g'li

KORRUPSIYA JAMIYAT RIVOJINING ZAVOLI ....

Б.Х. Хамидов

КИБЕРЖИНОЯТЛАРНИ ТЕРГОВ ҚИЛИШДА ЭКСПЕРТ КЎРСАТУВЛАРИНИ

ТЕКШИРИШ ВА БАХОЛАШ.

Каюмов Бахтиёр Эркинжонович

ВЛИЯНИЕ ДОГОВОРНЫХ ХАРАКТЕРИСТИК НА ЭФФЕКТИВНОСТЬ

ГОСУДАРСТВЕННО-ЧАСТНОГО ПАРТНЕРСТВА

Н.Т.Тургунова

ЁШЛАР ТАРБИЯСИДА ДАВЛАТ ВА ФУҚАРОЛИК ЖАМИЯТИ ИНСТИТУТЛАРИНИНГ

ХАМКОРЛИГИ

\section{TECHNOLOGY}

Sh.A.Abduraxmanova, A.A.Sultonmurodov

POSSIBILITIES OF USING TEACHING VIDEO LESSONS IN THE EDUCATIONAL

SYSTEM.

Артикбаева Нозима Муминджановна

ТИКУВ БУЮМЛАРИНИГА ИШЛОВ БЕРИШДА РЕСУРСТЕЖАМКОР

ТЕХНОЛОГИЯСИ РИВОЖЛАНИШИНИНГ ЗАМОНАВИЙ ХОЛАТИ

Кодиров Ф.К. Кенжаев С.Н. Убайдуллаев Г.К.

КОНСТРУКТОРСКО ТЕХНОЛОГИЧЕСКИ Е МЕТОДЫ ПОВЫШЕНИЯ

РАБОТОСПОСОБНОСТИ ДВИГАТЕЛЕЙ

Убайдуллаев Ғ., Кодиров Ф.

АНАЛИЗ ФОРМИРОВАНИЯ ПОГРЕШНОСТИ ФОРМЫ ДЕТАЛИ В ПРОЦЕССЕ

ОБРАБОТКИ.

Х. Имомназаров, А. Омонов

СИСТЕМА УРАВНЕНИЙ ДВУХСКОРОСТНОЙ ГИДРОДИНАМИКИ БЕЗ

ДАВЛЕНИЯ. 


\title{
SCUTELLARIAL GROUP USED IN MEDICINE MEDICINAL PROPERTIES AND DISTRIBUTION OF TYPES
}

\author{
Iskandarova Dilfuza \\ Student of Bukhara State Medical Institute \\ Shodmonova Aziza \\ Student of Bukhara State Medical Institute
}

\begin{abstract}
Annotation: In this article, the flora of Uzbekistan Cocamaron (Scutellaria.L) of the family Lamiaceae about the medicinal properties of medicinal and medicinal species and their prevalence reference is given.
\end{abstract}

Keywords: rheumatism, spasm, flavonoids, alkaloids, vegetation, vitamins, preparation.

The plant world is one of the riches of nature. Of course the healing properties of plants were known in ancient times and from them used in the treatment of various diseases. Abu Ali, the great Scholar of the Sixties ibn Sina, Abu Bakr ar-Razi, with medicinal plants from Beruni patients treated Medicinal for the treatment and prevention of diseases different types of medicines are made from plants. Plants for this rich in biologically active substances that have therapeutic properties parts of plants - from the underground parts of some plants (roots, rhizomes) or onions), and some from above-ground organs (leaves, flowers, fruit seeds) or the entire upper part of the horse plant - grass).

There is a growing interest in the medicine of the past among the people today is going. The main reasons for this are when modern medicine is weak, people. The fact that medicinal plants used in medicine give positive results, their low negative impact on the human body and economic ease is calculated.

Due to the growing demand for raw materials for naturally growing medicinal plants, one of the most pressing issues is the protection of natural medicinal plants, the identification of reserves for their rational use and recommendation for production. One such medicinal plant is poppy (Scute 1laria.L.).

A plant belonging to the Lamiaceae family, There are 40 species in this category in Uzbekistan. The following plant species are used in medicine.

1.Hisor greens- Scutellaria hissarica b.fedtsch.Perennial, many numbered stems, branched, hairless, $20-50 \mathrm{~cm}$ in height. The leaves are broad The leaves above, spherical, broadly ovate, with large serrated teeth at the edges the edges are smooth. The flowers are located in the axils of leaves, each with a short handle. The cup is $5 \mathrm{~mm}$ long and reaches $7-8 \mathrm{~mm}$ when the seeds are ripe. The petals are dark purple, 22-25 mm long, with yellow, purple spots on the upper flower.

It flowers in May-June and the seeds ripen in July-August. The middle of the mountain grows on rocks in the regions. Surkhandarya region (in the Gissar ridge Sangardak, in the Topalang river basins). In medicine, bleeding from the nose by making tea from flowers and leaves drink In colds, it is also used when the gastrointestinal tract is inflamed. Heart also in vascular disease, as a sedative, invigorating applied.

2. Scutellaria galericulata L. Perennial, stem four-sided, branched from the top, height 40-50 $\mathrm{cm}$. The leaves are short-stemmed, the base is heart-shaped, fine-toothed, the surface is hairless, the underside is sparsely hairy. The flowers are single, located in the axils of the upper leaves. The cup is small feathers The seeds are $3.5 \mathrm{~mm}$ long, $6 \mathrm{~mm}$, with a pleasant odor. The petals are light purple, 13-16 mm long. The nut is spherical $1.5 \mathrm{~mm}$ long, light brown, hairless, finely branched.

It blooms from late May to August and the seeds ripen in July-September. Rivers, grows in moist places, on the banks of ditches, and rice fields. Tashkent, Samarkand, Distributed in Fergana, Surkhandarya regions and Karakalpakstan. In folk medicine, tinctures of roots and rhizomes of all kinds of blood diarrhea, gastrointestinal tract, kidneys, respiratory tract, rheumatism, insomnia, heart playful, isthmus-lowering, anti-malarial, used in vomiting.

3. Scutellaria oxystegia juz. Perennial, rare The annual pillars of 5-10 cm long, herbaceous plant, cushioned in number. The leaves are elliptical, in some cases smooth at the edges. The flowers are the 
leaves above located in the armpit. The cocoon is $2 \mathrm{~mm}$ long, slightly mature at seed lengthen. The petals are pale yellow, 25-30 mm long.

Flowering in June-August, seeds ripen in July-September. The middle of the mountains grows on rocks in the regions. Tashkent (shagaltag) Fergana, Samarkand distributed in the provinces. In medicine, against the spasmodic diseases of the roots of this plant applied.

Human life is inextricably linked with the plant kingdom. To all It is known that the plant world feeds, clothes and purifies the air It creates beautiful corners, creates a beautiful landscape that is pleasing to the eye. It is difficult to enumerate the intoxicating properties of plants. Forest According to the State Committee for Agriculture, there are more than 4,500 farms in the country There is a highgrade plant species. Of these, 500 have healing properties They are widely used in modern medicine and folk medicine. Unfortunately, 342 species of plants in the forest fund are now extinct is on the verge of leaving. We are talking about the properties of the plant kingdom One of their great qualities is their healing properties it is impossible without stopping. The above is one of the medicinal plants we met one.

\section{References:}

1.Medicinal plants found in the flora of Uzbekistan (S. Meliboyev and others) - Fergana Publishing House - 2018

2.Plant Identifier (Handbook for School Teachers, 2nd ed S.Khalikov, O.Pratov, A.Fayziev) Tashkent "Teacher" 1995

3.https: //uz.m.wikipediya.org

4.https: // www.plantarium.ru 


\title{
TO STUDY THE NEUROPROTECTIVE EFFECT IN THE CORRECTION OF CHANGES IN THE BRAIN IN EXPERIMENTAL HYPOTHYROIDISM .
}

\author{
Muminova Guyoxon Alijanovna \\ Senior Lecturer, Department of Biological Chemistry, \\ Andijan State Medical Institute \\ muminovaguyo@mail.ru.Tel: 97-346-15-83
}

\begin{abstract}
Annotation. Chronic hypothyroidism causes various morphological changes in the brain. An experimental model of hypothyroidism was developed to study morphological processes in the brain. To do this, mercazolil was injected into the stomach of arrow rats at a dose of $2.5 \mathrm{mg} / 100$ g per day for 21 days. Then was divided into groups and for 10 days the first group was treated with thyroxine, the second group with thyroxine and Neuromak, and changes in brain morphology were observed. The indicators in the groups treated with a combination of thyroxine and Neuromac approached the norm.
\end{abstract}

Keywords: hypothyroidism, thyroxine, neuroprotector, mercazolyl, brain morphology.

Objective: To determine the effect of neuroprotectors on morphological changes in the brain in experimental hypothyroidism.

Materials and methods. To obtain a model of hypothyroidism, mercosaline at a dose of $2.5 \mathrm{mg} /$ $100 \mathrm{~g}$ was administered to white rats by gastric administration for 21 days $[1 ; 10]$. The development of hypothyroidism was confirmed by monitoring body temperature, body weight gain, and general condition of the animals, and by detecting TTG, T3, and T4 hormones. Rats with hypothyroidism were treated with thyroxine and a "neuromac" neuroprotector for 10 days. X animals were anesthetized by decapitation, and fragments from the cerebral cortex and hippocampus were obtained. Brain tissue fragments were solidified for $72 \mathrm{~h}$ in a $10 \%$ phosphate buffer solution of formalin. It was then dewatered, poured into paraffin, bricks were prepared, and histological incisions were made. Histological incisions were stained with hematoxylin-eosin and Nissl stains and examined under a light microscope, and the desired areas were photographed.

Conclusions and discussion: The following data was obtained from microscopic examination of the cerebral cortex and hippocampal tissue after correction of experimental hypothyroidism with thyroxine and neuromack neuroprotector. On day 10 of the hypothyroidism combined correction experiment, there were almost no circulatory, edematous, and dystrophic changes in the cerebral cortex tissue, with only a small focal local edema process preserved around some small capillaries. The peculiarity of this period is that in the cerebral cortex tissue the above-mentioned diffuse gliosis process is slightly intensified. Morphologically, glial cells have different shapes, concentrated around neurons in some areas and concentrated around blood vessels in other areas. It is found that the nerve cells of the brain tissue are densely packed, unlike the anterior ones, most of which are both hypertrophied and hyperchromatic (Fig. 3). Their nuclei are stained dark and diffuse with hematoxylin, and an increase in chromatin is observed. Brain Tissue Nissl-stained brain tissue found that all neurons in the brain tissue, including pyramidal neurons, were relatively dark-stained, i.e., they increased the amount of chromatophilic substance in the cytoplasm (Fig. 4) and the tigroid substance was distributed along neuronal fibers. It is observed that the nuclei of neurons are mostly round and their nuclei are stained dark blue. 


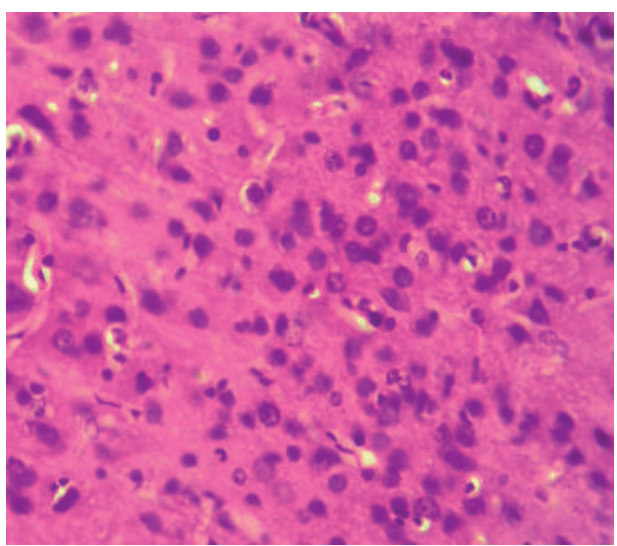

Figure 3 Thyroxine and neyromak swim group of hi 10 days, a brain bark. There is no tumor in the brain tissue, all neurons are hypertrophic and hyperchromatic. Paint: G-E. $\mathrm{X}: 10 \mathrm{x} 40$.

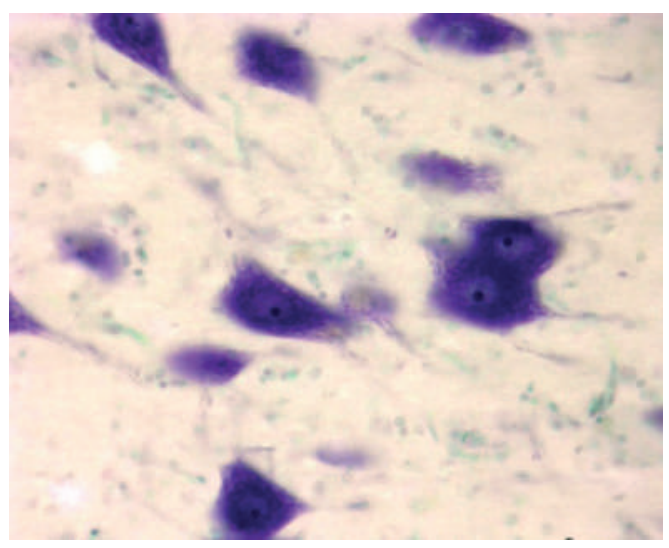

Figure 4 . Thyroxine and neyromak swim group of hi 10 days, a brain bark. The cytoplasm of neurons is filled with tigroid substance. Dye: Nissl method. X: 10x90.

In the later periods of the experiment, i.e. by 10 days, it is observed that in the hippocampal tissue there is a complete disappearance of morphological features characteristic of distirculatory, edematous and dystrophic processes. Hippocampal neurons retained a distinctive, i.e., band-shaped set of cells, all the neurons in the band, i.e., round-shaped neurons in the peripheral row, and the pyramidal neurons in the middle, retained their histotopographic and histochemical structure (Fig . 5) . The fact that the cytoplasm of all types of neurons is stained purple with eosin, the nuclei are stained dark orange, indicates the activation of their morphofunctional state [2, 5 ]. The brain substance around the neuronal band is also stained purple with eosin, and the glial cells in it are also morphologically active. When hippocampal tissue is stained by the Nissl method, the activity of the morphofunctional state of the neurons in it is confirmed by the abundance of tigroid substance in the cytoplasm, in a scattered and intensively stained state (Fig . 6). Even in the cytoplasm of sparsely located neurons in the molecular layer of the hippocampus, tigroid substance appears to accumulate in large quantities.

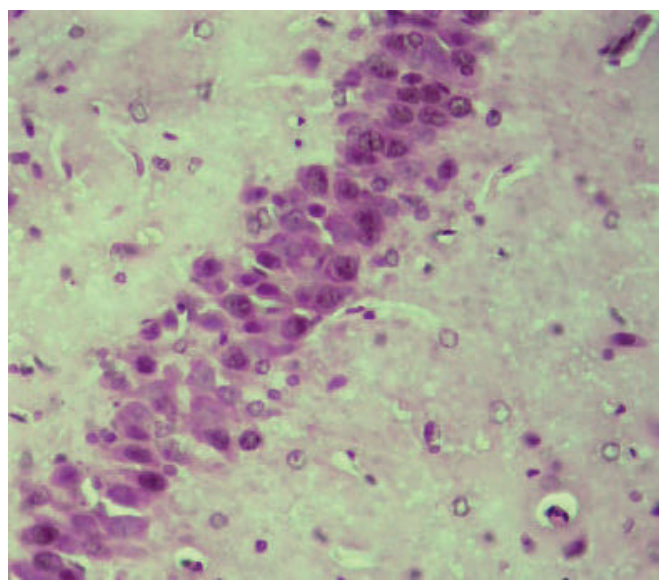

Figure 5 Correction group with thyroxine and neuromac, 10-day, hippocampus. Hypertrophy and hyperchromia of neurons. Paint: G-E. X: 10x40.

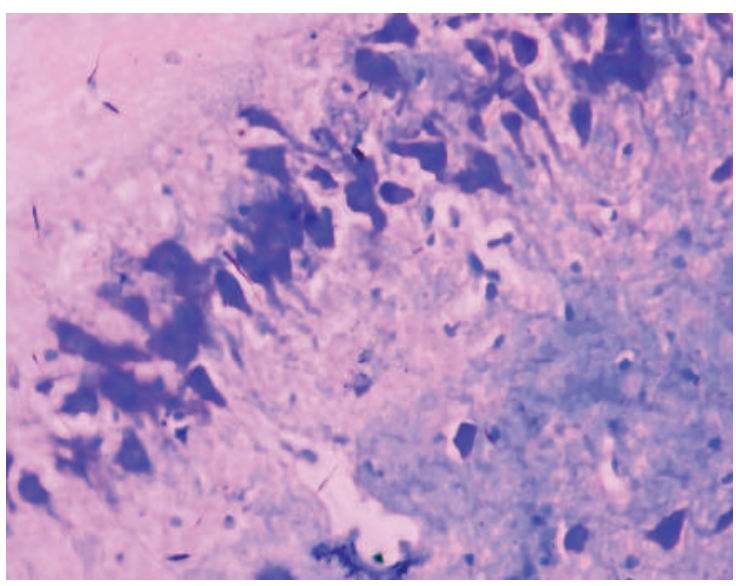

Figure 6 Thyroxine and neyromak swim team hi, 10day, gippokamp. An increase in thyroid substance in the cytoplasm of neurons. Dye: Nissl method. X: $10 \times 40$.

\section{Conclusion.}

When experimental hypothyroidism is corrected by a combination of thyroxine and neuroma, from the initial period of the experiment it is observed that the circulatory and tumor processes in the brain and hippocampal tissue stabilize and decrease. Absence of perivascular and pericellular tumors in the cerebral cortex and hippocampal tissue, activation of the morphofunctional state of both neurons and glial cells, ie hypertrophy and hyperprombosis, stimulation of neuroprotectors, cell membrane structures indicates 


\section{References:}

1. Afanasyev V.V. Clinical application of citicoline and its role in homeostasis of cell membranes of neurons and effector organs. // emergency medicine. -2016. No. 1 (72). - S.46-50.

2. Grigorova I.A., Tovazhnyanskaya E.L. Pathogenetic aspects of the formation of neurological complications of primary hypothyroidism // News in neurology: XI Mizhnar. Conf. - Sudak, 2009. - pp. 338-343.

3. Makar R.D., Sandurska M.V. Hypothyroidism: conceptual aspects across the prism of the hour // International. endocrinology journal. - 2009. - No. 1 (19). - P.124-131.

4. Namazova L.S., Shirokova I.V. Prevention of iodine deficiency diseases // Pediatric Pharmacology.- 2008.- No. 2.- P.108-111.

5. Tovazhnyanskaya E.L. Neurological complications of primary hypothyroidism of various origins // International medical journal.- 2013.- №1 .- P.15-19.

6. Troshina E.A. Algorithm for the diagnosis and treatment of hypothyroidism // Pharmateka.2008.- №12.- P.68-70.

7. Braverman LE, Utiger RD The thyroid: a Fundamental and clinical text. 10th ed. Philadelphia: Lippicott Williams \& Wilkins, 2013.- P.735-878.

8. Lee E., Kim, S., Chung H, Park Ch. Dopamine neuron induction and the neuroprotective effects of thyroid hormone derivatives. // Scientific Reports-2019.-Vol.9.-136 159. https://doi. org/10.1038/s41598-019-49876-6 .

9. Nunez J., Celi FS, Ng L., Forrest D. Multigenic control of thyroid hormone functions in the nervous system. //Molecular and Cellular Endocrinology.- 2008.- Vol.287 (1-2) .- P.1-12.

10. O‘hare E., Kim E.-M., Page D. , Reid R. Effects of thyroxine treatment on histology and behavior using the methimazole model of congenital hypothyroidism in the rat. // Neuroscience.2015.- Vol.285.- P.128-138. 


\title{
ПЕРИОД РЕКОНСТРУКЦИИ И ВОССТАНОВЛЕНИЯ ИСТОРИИ НАШЕГО НАРОДА В ГОДЫ НЕЗАВИСИМОСТИ.
}

\author{
Джабборов Мухаммаджон \\ Студент Нав.Г.П.И \\ Рахматов М.Г.
}

Научный руководитель: доцент.

Мир широк, в мире много стран, но в этом мире уникальна наша уникальная Родина, Узбекистан. Уникальность страны под названием Узбекистан отражается в ее уникальной природе, богатой истории, трудолюбивых людях, а также в том, что люди разных национальностей и национальностей живут на этой земле как дети одной семьи. Такое согласие, дружба и сотрудничество имеют глубокие исторические корни и основы. Когда проводится справедливая национальная политика, полиэтничность помогает понять единство наших целей, единство нашей судьбы, необходимость солидарности, приоритет универсальных идей и правильное понимание личных интересов. Напротив, отсутствие бдительности и чувствительности в национальных отношениях и даже небольшое пренебрежение национальными принципами могут иметь негативные последствия для мира и стабильности. Все сегодняшние реформы служат дальнейшему укреплению нашей независимости. Потому что в этой небесной стране родилось так много великих и достойных людей. Если мы возьмем пример Имама Аль-Бухари как великого знатока хадисов, хадисы, которые он собрал как великий ученый, любимы и почитаемы во многих странах. Достижение независимости Республики Узбекистан имело большое значение. В этот период принятие Закона о государственном языке под руководством Первого Президента стало первым шагом к независимости. 24 марта 1990 года учреждена должность Президента Узбекистана. Теперь главной задачей было принятие Декларации о государственном суверенитете Республики Узбекистан, документа, имеющего большое значение в исторической судьбе страны и народа, потому что эта декларация была главным критерием создания свободы и свободы нашего народа. люди. В следующей декларации учтены многовековой исторический опыт и традиции узбекского народа. В Декларацию независимости, принятую на 2-й сессии Верховного Совета Узбекской ССР 20 июня 1990 года, были включены некоторые положения, касающиеся формирования Национальной армии, и состояла из 12 статей. С этого дня вопросы экономической и политической жизни республики стали решаться самостоятельно. Именно в этот период была издана первая новая книга о независимости. Первая книга Президента Ислама Каримова, изданная в 1991 году, была издана в газете. Узбекистан. «Мы делаем все возможное, чтобы наши люди были не хуже всех в мире, а наши дети были сильнее, образованнее, мудрее и, конечно же, счастливее, чем мы». Вопрос духовного воспитания, несомненно, имеет первостепенное значение. Если мы потеряем бдительность и чуткость, решимость и ответственность в этом вопросе и оставим эту очень важную вещь на произвол судьбы, мы можем потерять историческую память о наших духовных ценностях, которые подвергались нападкам и подпитывались нашими священными ценностями. Состоявшаяся 31 августа 2013 года VI внеочередная сессия Верховного Совета Республики Узбекистан XII созыва сыграла важную роль в провозглашении Узбекистана независимым государством. Потому что это была вечная мечта нашего народа.

Во-первых, одобряете ли вы Государственную независимость Республики Узбекистан 29 декабря 1991 года? Результаты референдума - яркий тому пример. В референдуме приняли участие 94,1\% или 9898707 зарегистрированных избирателей. За государственную независимость Республики Узбекистан проголосовало 9 миллионов 718 тысяч 555 человек или $98,2 \%$ от числа принявших участие в референдуме. Это событие помогло народу Узбекистана определить свою судьбу и создать политическую систему в обществе. С первых дней нашей независимости Национальной идееуделялось большое внимание. Как сказал Первый Президент, я думаю, что если мы представим лучшие стремления и чаяния любого народа, мы сможем выразить суть такого широкого Концепция. Сегодня внимание к национальной идее возросло как никогда. Это связано с тем, что в высшем учебном заведении началось преподавание науки 
как нового предмета. Это помогло поднять отношение студентов к национальной идее. Мы в силах выполнить великие задачи, поставленные перед нами Президентом Мирзиёевым в Послании парламенту. - национальный герой, который будет источником власти. Подчеркнута необходимость нашего развития. В частности, нам необходимо понять национальную идентичность, изучить древнюю и богатую историю нашей страны, усилить исследования в этой области и полностью поддержать работу ученых-гуманитариев. Оценка прошлого должна быть объективной и, что самое главное, свободной от разногласий. «Есть люди, которые считают старую советскую идеологию национальной идеей», - сказал он. Это тоже правда, но если идеология человечна, если она служит прославлению прав и свобод человека, чего нам бояться? Основа всех наших действий - это удовлетворение наших людей, основа всего, что мы делаем с точки зрения гуманности. В этой связи хочу подчеркнуть, что создаваемая нами идеология Нового Узбекистана будет идеей добра, человечности и гуманизма »2. В заключение, национальная толерантность достигается через уважение к языку, религии, образу жизни, обычаям и традициям, национальному культурному наследию людей разных национальностей, уважение их чести, достоинства и достоинства. Представляет собой определенную духовную широту (толерантность). Национальная толерантность не достигается, наоборот, в ущерб национальным интересам. Он будет укрепляться на основе сбалансированного взгляда на интересы разных народов.

\section{Использованная литература}

1.Каримов.ИА «Узбекистан на пороге независимости» -T Uzbekistan 2011_-127 с.

2.Каримов.ИА «Высокая духовность - непобедимая сила»-Т Духовность $2 \overline{0} 08$ - 4 страницы. 3.Мирзиёев.Ш.М. - Заявка 29.12.2018.

4.Мирзиёев.Ш.М. - Из собрания по вопросам духовного просвещения 19 января 2021 года. 


\section{БАДИИЙ АСАР ТАЪЛИМДА - ЖАМИЯТНИ МАЪНАВИЙ РИВОЖЛАНИШИНИНГ МУХИМ ОМИЛИ СИФАТИДА}

Нусратова Шоира Иватовна

Ўзбекистон давлат санъат ва маданият институти “Санъатшунослик ва маданияшунослик”кафедраси катта ўқитувчиси

Аннотация: Мазкур мақолада санъташунослик таълим йўналишида "Бадиий асар тахлили" фанни ўқитишда интерфаол ўқитиш методи хамда унинг бугунги кундаги ахамияти ўрганилган.

Калит сўзлар: Танқиди ва тахлили, театр санъати, кино санъати, асарни композициясини интерфаол ўқитиш методи.

Таълимга эътибор - келаэсакка эътибор. Таълим - тараққиёт босқичидаги энг мухим тизим. Жамики уззгаришлар, янгиланишлар бевосита таълим ривожи билан боzлиқ. Президентимиз

Шавкат Мирзиёев [1. 24-б.]

Инсоният XXI асрга катта хаётий тажриба, бир олам билим ва юксак даражада ривожланган фан-техника ютуқлари билан кириб келди. Дунё халқлари маданий жихатдан ўзаро яқинлашдилар. Санъатнинг турли сохаларида мисли кўрилмаган ютуқлар кўлга киритилди. Инсондаги биринчи ижтимоий эхтиёж тарбияга ёки тарбияланишга бўлган эхтиёждир. Бу эхтиёжни хамма хам, айниқса, гўдаклиги ва болалигида зарур нарса сифатида қабул қилавермайди. Демак, тарбия, хам санъат маданият хам, инсониятнинг мавжудлик, бархаётлик шарти сифатида жамиятнинг онгли ва маданиятли қатламлари томонидан яратилади.

Маълумки, давлатимиз рахбари ижтимоий, маънавий-маърифий сохалардаги ишларни янги тизим асосида йўлга қўйиш буйича 5 та мухим ташаббусни илгари сурган эди.

Биринчи ташаббус ёшларнинг мусиқа, рассомлик, адабиёт, театр ва санъатнинг бошқа турларига қизиқишларини оширишга, истеъдодини юзага чиқаришга хизмат қилади. Ўзбекистон маданияти, бадиий адабиёти ва тасвирий санъати, кино санъати, театр санъати хусусан, санъатшунослик сохасида хам умумий жихатлар кўп.

Санъатшунослик - эстетика, тасвирий санъат асослари, Сахна ва экран санъати драмтургияси, кино санъати танқиди ва тахлили, театршунослик, мусиқа назарияси каби фан сохаларини ўз ичига олади. Санъат ва ижод эса ўз навбатида маданиятшуносликнинг хам объектидир. Гўзаллик ижод қилиш, кишиларнинг хис-туйғуларини ўстириш, уларни ранглар, оханг ва товушлар ранг-баранглигини илғашга ўрганиш муаммолари маданиятшуносликни хам қизиқтиради. У халқ амалий санъати, театр санъати, кино санъати, халқ мусиқаси ва қўшиқчилиги анъаналарини сақлаб қолиш хамда ривожлантириш йўлларини ишлаб чиқади.

Замонавий шароитда таълим самарадорлигини оширишнинг энг мақбул йўли - бу машғулотларнинг интерфаол методлар ёрдамида ташкил этиш деб хисобланмоқда. Хўш, интерфаол методларнинг ўзи нима? Улар қандай дидактик имкониятларга эга? Таълим жараёнида интерфаол методларнинг ўринли, мақсадга мувофиқ қўлланилиши қандай самараларни кафолатлайди?

Мантиқий нуқтаи назардан интерфаоллик, энг аввало, ижтимоий субъектларнинг сухбат (диалог), ўзаро хамкорликка асосланган харакат, фаолиятнинг олиб боришларини ифодалайди.

Анъанавий таълимдаги бир томонламалик олий таълим тизимидаги фақат маъруза машғулотларида эмас, семинар дарсларида хам устуворлик қилади. Унга кўра, “етказиб берувчи" ролида энди ўқитувчи эмас, балки талаба намоён бўлади. Талаба, асосан, ўзи ўзлаштирган билимларни намойиш этади, ўқитувчи эса унинг фикрларини тинглайди, зарур ўринларда саволлар билан мурожаат қилади. Талабалар гурухи (жамоаси) бу вазиятда бутунлай суст иштирокчи, тингловчи бўлиб қолади. Бир қарашда талаба ёки ўқитувчи томонидан узатилаётган ахборотларнинг қабул қилиниши талабалар гурухи (жамоаси) учун билимларни ўзлаштириш имкониятини яратаётгандек таассурот уйғотади. Бироқ, психологик тадқиқот натижаларининг кўрсатишича, шу тарзда қабул қилинган билим (маълумот)лар жуда тез унутилади. 
Шунга кўра интерфаол ўқитиш “таълим жараёнининг асосий иштирокчилари - ўқитувчи, талаба ва талабалар гурухи ўртасида юзага келадиган хамкорлик, қизғин бахс-мунозалар, ўзаро фикр алмашиш имкониятига эгалик асосида ташкил этилади, уларда эркин фикрлаш, шахсий қарашларини иккиланмай баён этиш, муаммоли вазиятларда ечимларни биргаликда излаш, ўкув материалларини ўзлаштиришда ўқувчиларнинг ўзаро яқинликларини юзага келтириш, “ўқитувчи - талаба - талабалар гурухи”нинг ўзаро бир-бирларини хурмат қилишлари, тушунишлари ва қўллаб-қувватлашлари, самимий муносабатда бўлишлари, рухий бирликка эришишлари кабилар билан тавсифланади”[ 2. Б.122 ].

Интерфаол методлардан фойдаланиш таълим жараёнида “субъект-субъект” алоқасини таъминлабгина қолмай, талабаларда креативликни, масьулиятни, мустақил фикрлашни ва лидерликни шакллантиради. Бу эса, келажакда жамият тараққиётига хисса кўшувчи мутахассисларни тайёрлашда жуда мухимдир.

Яратилган “Тахлил” методи талабалар жамоа ва якка тартибда қатнашади. Ўқитувчи саньат асарларини бадиий, мантиқий, фалсафий, психологик каби тахлил турлари ўргатилади. Ушбу тахлил турларидан бири пьесани ўқиб ва ушбу пьеса асосида сахналаштирилган сахна асарларини тахлилга тортилади.

Бирон асарни композициясини тахлил қилиб ўргатилади. Тахлил қилишда оддий жадвал асосида бир томонига асарни номи ёзиб борилади ва иккинчи томонига унинг тузлиши ёзилади. Жадваллар асосида якка холда 2 та ёки гурухларга бўлиниб берилган асар композицияси ёки унинг ечимини бадиий тахлил қиладилар. Мусобақа асосида доскада гурухларга балл қўйиб борилади. Энг яхши гурух рағбатлантирилади. Худди шу усулда асарларни мантиқий фалсафий, психологик усулларда тахлил қилинади.

Масалан асарни сюжети ўрганиш жараёнида талабаларга унинг тузилиши ёзиб борилади. Иккинчи томонга эса асарни мазмун мохияти ва маьноси ёзиб борилади. Фикрлар умумлаштирилиб хулосаданади. “Бадиий асар тахлил” усулни мақсади дарс жараёнида талабалар эркин, мустақил, танқидий фикрлашга изланишга, таққослаш усули ёрдамида берилган топшириқларни келиб чиққан холда муаммо ечимини топиш, мустақил бажарган ишини эркин баён эта оладиган ўзини ўзи бахолаш бошқалар фикрига хурмат билан қараш керакки фикрни ўз ўрнида билимларига, бадиий асарларни мантиқий фикрлашга, гўзаллик қалбидаги хикматни ўқишни ўрганадилар. "Энди, эй, қардошлар! - деган эди буюк мутафаккирларимиздан Чўлпон, - Адабиёт ўқуйлик. Адиблар етиштирайлук, “адабиёт кечалари” ясайлук. Рух, хис, туйғу, фикр, онг ва ўй олайлук, билайлук. Агарда “баёз” ва бемаъни бир-икки дона китоблар ила қолсак, махви инқирозий бўлурмиз. Юрагимиз кундан-кун тошдан хам қаттиғ бўлур. Юракни эритайлук, рух берайлук, инқироз бўлмайлук” . [4. 37-б.]

\section{Фойдаланилган адабиётлар:}

1. Ўзбекистон Республикаси Президенти Шавкат Мирзиёевнинг Олий Мажлисга Мурожаатномасини ўрганиш ва кенг жамоатчилик ўртасида тарғиб этишга бағишланган илмийоммабоп кўлланма Тошкент -“Маънавият” 2019. 24-б.

2. У.И.Иноятов, Н.А.Муслимов, М.Усмонбоева, Д.Иноғомова. Педагогика: 1000 та саволга 1000 та жавоб / Методик қўлланма.- Тошкент: Низомий номидаги Тошкент давлат педагогика университети, 2012.

3. Жамолдинова О. Каримова О, Исроилова Г. Хаётимиз қомуси// Педагогик таълим. Тошкент, 2012. - № 6. - Б.3-6. (13.00.00. № 6)

4.Чўлпон. Адабиёт надир? -Т.: Чўлпон, 1994. 37-бет 


\title{
ЎСМИР БОКСЧИЛАРНИНГ ПСИХОЛОГИК ТАЙЁРГАРЛИГИ ҒАЛАБА ГАРОВИ
}

\author{
Хўжаев Дониёр \\ “Темурбеклар мактаби” харбий-академик \\ лицей жисмоний тарбия ўқитувчиси
}

\begin{abstract}
Аннотация: Ушбу мақолада ўсмирлик давридаги боксчини ўзини-ўзи англашида психологик тайёргарлигини қандай йўллар ривожлантириш ва унинг сабаб ва омиллари хақида фикр юритилади. Шунингдек ўсмир боксчиларининг психологик-пеадагогик ва физиологик масалалар бўйича илмий ва илмий методик адабиётларни тахлил қилиш, кичик ўсмирлик ёшидаги боксчиларни мусобоқаларга тайёрлашнинг пеадгогик жараёни билан боғлиқ бўлган асосий анъаналари, истиқболлари ва долзарб муаммолари хақида сўз боради.

Калит сўзлар: Спорт, мусобақа, беллашув, психология, педагогика, муаммо, тахлил, мураббий, чемпионат.
\end{abstract}

Аннотация: В данной статье обсуждаются способы развития психологической готовности боксера к самосознанию в подростковом возрасте и его причины и факторы. Также проведен анализ научно-методической литературы по психологическим, педагогическим и физиологическим проблемам юных боксеров, основным традициям, перспективам и актуальным проблемам, связанным с педагогическим процессом подготовки юных боксеров к соревнованиям.

Ключевые слова: спорт, соревнования, соревнования, психология, педагогика, проблемы, анализ, тренер, чемпионат.

Annotation: This article discusses ways to develop the psychological readiness of a boxer for selfawareness during adolescence, and its causes and factors. There is also an analysis of scientific and methodological literatures on pedagogical and physiological issues of adolescent boxers, the main traditions, prospects and current issues related to the pedagogical process of preparing young boxers for competitions.

Keywords: Sports, competition, competition, psychology, pedagogy, problem, analysis, coach, coach, championship.

Ўзбекистон Республикаси Президентининг 2020 йил 24 январдаги “Ўзбекистон Республикасида жисмоний тарбия ва спортни янада такомиллаштириш ва оммалаштириш чора-тадбирлари тўғрисида" ги ПФ-5924 сонли фармони хамда “Таълим тўғрисида"ги Қонунининг ишлаб чиқилиши спортчи мавқеини белгилаб олишини таъминлашга ориентация қилиш ва уни амалга ошириш учун шароит яратиш хисобланади. Жумладан фармоннинг 3-бандида “спортчи ёшларни саралаш ва катта спортга иқтидорли спортчиларни танлаб олиш (селекция), спорт захирасини шакллантириш тизимини йўлга қўйиш, ёшлар орасида спортни оммалаштиришда юқори натижаларга эришиш мақсадида худудларнинг ўзига хос хусусиятлари, ахолининг қизиқиши ва хохиш-истакларидан келиб чиқиб, умумтаълим мактаблари олий таълим муассасалари камида биттадан устувор, истиқболдаги, ривожланаётган, шу жумладан миллий спорт турларига ихтисослаштирилади" дея таъкидланганлиги спорт турлари жумладан бокснинг хам жадал ривожланишига хисса қўшади.

Ўсмир ёшларга бокс спорт турини харакат амалларини ўргатишга, ахлоқий-иродавий ва жисмоний тарбиялашга йўналтирилган таълим-тарбия жараёнини индивидуаллаштириш имкониятлари педагогикада, психологияда, физиологияда ва спорт тренировкасининг назарияси ва методикасида кўриб чиқилади. Кўпчилик холатларда, ўқув-тренировка жараёни самарадорлигини ошириш йўллари илмий тадқиқотларда турли позициялардан туриб ечилган: харакат амалларини ўргатишнинг мумтоз усулларини кўллаш асосида ўсмир боксчиларнинг ўзига хос кўриши орқали идрок қилишларини ривожлантириш ва махсус тренажёр мосламаларни қўллаш йўли билан хамда педагогик ўзаро харакат қилишни ва ўсмир боксчилар шахсини шакллантиришни такомиллаштириш асосида ва темпераментнинг индивидуал-типологик хусусиятларини хисобга олиш асосида психологик тайёргарлиги шаклланади. Келтирилган ишларни тахлил қилиш, спортда дастлабки ихтисослашиш босқичида ёш ўсмир боксчиларнинг ўкув-тренировка жараёни самарадорлигини ошириш йўлларидан бири - ушбу жараённи индивидуаллаштиришнинг педагогик шартларини ишлаб чиқиш хисобланади.

Ёш ўсмир боксчиларни мухим мусобақаларга тайёрлашнинг педагогик жараёни нафақат жисмоний сифат ва билимларни, харакат усулларини ривожлантиришга йўналтирилган, бал- 
ки ўзини ички дунёсини ривожлантиришга хам қаратилгандир. Юклама параметрлари сифатида кўпгина муаллифлар тренировка ишининг соф вақтини - тренировка юкламаси хажмини машғулотларнинг умумий вақтини, тренировка юкламаси шиддатини, шунингдек интеграл кўрсаткични - хажмни шиддатга (шартли балларда) айлантиришни хисобга олишни таклиф қилади.

Улар тренировка тузилмаси мазмунини тўлиқ хажмда, айниқса, ихтисослашганлик ва координацион мураккаблик параметрлари бўйича оқилона режалаштиришни амалга оширишга имкон бермайди. Боксчиларнинг жисмоний тайёргарлик назариясида жисмоний юкламаларни хар қандай жисмоний машқни бажариш билан боғлиқ бўлган юкламаларни уларнинг давом этиши, шиддати ва хар қандай жисмоний машқнинг организм тўқималарида хосил бўлган ахборот сонига таъсир кўрсатиши даражасини хисобга олган холда таснифланади.

Ўсмир ёшдаги боксчиларнинг тренировкаси юкламаларни таснифлаш учун «кислородни максимал истеьмол қилиш»нинг ўсиш ўлчамлари, «лактат чегараси» ва «вентиляцион чегара»ни, шунингдек улар ўртасидаги боғлиқлик хусусиятини хисобга олиш керак. Тренер боксчининг махсус чидамлигини аниқлаб берувчи омиллар ва у ёки бу машқни тайинлаш тўғрисида аниқ тасаввурга эга бўла туриб, унинг махсус жисмоний тайёргарлигини янада мақсадли равишда олиб бориши мумкин.

Ўсмир боксчиларнинг функционал тайёргарлигининг иш қобилияти кўрсаткичлари билан ўзаро боғлиқлигини янада чукур ўрганиб чиқишда организм етакчи тизимларининг потенциал имкониятларини аниқлаб берувчи омилларни, иккинчи томондан, бўш бўғинлар ва чеклайдиган омилларни ажратиб кўрсатишга имкон беради.

Ўсмир боксчиларини тайёрлаш технологиясининг батафсил ишлаб чиқилганлиги катта эътиборгалойиқ. Ушбу технология чукур индивидуаллаштирилган хамда касбга йўналтирилган. Шу жихатдан турли тайёргарлик босқичларида юкламаларни меъёрлаш вазифаларини хал этиш катта ахамиятга эга. Ўсмир боксчиларнинг тренировкасидаги жисмоний юклама - бу боксчига таъсир кўрсатувчи кўпгина омиллар қаторида ягона, яъни психологик тайёргарлик имкониятларини, жисмоний ва ақлий иш қобилиятини хақиқатдан хам ошира оладиган фавқулоддаги вазиятларни енгиб ўтиш учун энергия захирасини ярата олишга қодир бўлган омил хисобланади. Ўсмир боксчиларининг мусобақа олди психологик тайёргарлик босқичида юкламаларнинг таъсир этишида малакали спортчиларнинг индивидуал хусусиятларини хисобга олишни таклиф қилади.

Бундай холларда ўсмир боксчиларининг психологик ва рухий-физиологик тавсифларнинг индивидуал динамикасини хисобга олиш, олимларнинг фикрича, тренировка юкламасининг спортчи организмига бир хилда таъсир кўрсатишини оширади хамда мавсумдаги хал этувчи стартлар учун спортчида мустахкам эмоционал- иродавий мухитни шакллантиради.

Бокс тренировка машғулотлари сони анча ортган пайтда, қачонки тикланиш учун дам олиш оралиғи алохида юклама билан эмас, балки етарлича узоқ вақт давомида қўлланиладиган хамма тренировка юкламаларининг умумий натижаси самараси билан аниқланганда, машғулотлар натижаси самарасининг узоқ куммуляцияси фонида юклама ва дам олиш нисбатлари маълум даражада қизиқиш уйғотади.

Хулоса қилиб айтганда, ўсмир боксчиларининг тренировка юкламаларини режалаштириш ва назорат қилишни такомиллаштиришдаги йўналишларнинг тахлили уларнинг психологик тайёргарлигини хисобга олган холда амалга оширилиши, ўсмир боксчиларни мусобоқаларда ғалабаларни қўлга киритиш учун долзарб хисобланади.

\section{Фойдаланилган адабиётлар}

1. Ўзбекистон Республикаси Президенти Ш.М.Мирзиёевнинг 2020 йил 24-январдаги "Ўзбекистон Республикасида жисмоний тарбия ва спортни янада такомиллаштириш ва оммалаштириш чора-тадбирлари тўғрисида" ги ПФ-5924 сонли фармони.

2. Ўзбекистон Республикасининг жисмоний тарбия ва спорт тўғрисидаги қонуни (янги тахрири). -Т, 2000, 26 май.

3. Турдиев Ф.К. Бокс тренерининг индивидуал дарс олиб бориш жараёнидаги махсус малакаларини шакллантириш: Дис...канд.пед.наук - Т., 2002. 


\title{
O'ZBEKISTON ERKIN IQTISODIY ZONALARIGA XITOY INVESTITSIYALARINI JALB ETISHNING ASOSIY YO'NALISHLARI (“JIZZAX" EIZ MISOLIDA)
}

\author{
Yuldosheva Inoyat Zikriyayevna. \\ Toshkent Irrigatsiya va Qishloq Xo“jaligini \\ Mexanizatsiyalash Muhandislari instituti, katta o'qituvchi \\ Toxirov Shohrux Janobil o' $\mathrm{g}^{6} \mathrm{li}$. \\ Toshkent Irrigatsiya va Qishloq Xo‘jaligini \\ Mexanizatsiyalash Muhandislari instituti, talaba
}

Annotatsiya. Ushbu maqolada O'zbekiston erkin iqtisodiy zonalariga xorijiy investitsiyalarni jalb etishning asosiy yo nalishlari "Jizzax" EIZ misolida tahlil etilgan. "Jizzax" EIZda joylashgan, xitoy sarmoyalari asosida ishga tushgan "Quyosh issiqlik energiyasi” MCHJ QK faoliyatiga alohida to 'xtalib o'tilgan. Shuningek, hamkorlikning kelgusi istiqbollari xususida ham fikrlar bildirilgan.

Kalit so'zlar: erkin iqtisodiy zona, xorijiy investitsiyalar, investitsiyaviy hamkorlik, Xitoy investitsiyalari, investitsiya muhiti, investitsiya loyihasi.

Har qanday mamlakatning ijtimoiy-iqtisodiy rivojlanishida tashqi iqtisodiy aloqalarning, birinchi navbatda investiyaviy hamkorlikning ahamiyati katta. Ma'lumki, investitsiya - iqtisodiyotning drayveri, ya`ni harakatlantiruvchi kuchidir. Shuni hisobga olgan holda O`zbekiston hududida tashkil etilgan erkin iqtisodiy zonalarning asosiy vazifasi sifatida chet el investitsiyalarini kengroq jalb qilish, import o'rnini bosuvchi va eksportbop tovarlar ishlab chiqarish belgilangan. Bu borada "Jizzax" erkin iqtisodiy zonasida ham samarali ishlar amalga oshirib kelinmoqda. Milliy iqtisodiyotimizga xorijiy investitsiyalarni jalb etishda mamlakatimiz hududida tashkil etilgan erkin iqtisodiy zonalarning o'rni beqiyos. Bugungi kunda yurtimizda 12 ta erkin iqtisodiy zona, 70 ta kichik sanoat zonalari faoliyat olib bormoqda. Barcha erkin iqtisodiy zonalarda umumiy qiymati 486 mln AQSH dollariga teng 62 ta loyiha amaliyotga tadbiq etilib, 4600 dan ortiq ish o' ${ }^{\prime}$ i yaratilgan. O'zbekiston Respublikasi Prezidentining 2013-yil 18-martdagi "Jizzax" maxsus industrial zonasini barpo etish to 'g risida"gi Farmoniga muvofiq tashkil etilgan ushbu erkin iqtisodiy zona bugungi kunga kelib O'zbekiston iqtisodiyoti rivojiga munosib hissa qo`shib kelmoqda. "Jizzax" EIZni rivojlantirish va chet el sarmoyalarini jalb qilishning ustuvor yo 'nalishlari asosida quyidagi tarmoq korxonalarini joylashtirish mo'ljallangan: elektronika va elektrotexnika, mashinasozlik va metallni qayta ishlash, qurilish materiallari, kimyo, yengil sanoat, oziq-ovqat sanoati, farmasevtika. "Jizzax" EIZda Buyuk Britaniya, Germaniya, Rossiya, Koreya Respublikasi, Xitoy, Hindiston singari davlatlar bilan investitsion loyihalar amalga oshirilgan. Muvaffaqqiyatli investitsiya loyihalarining umumiy soni 16 tani tashkil etadi. Erkin iqtisodiy zonada xorijiy mamlakatlar, xususan, xitoylik investorlar bilan hamkorlikda amalga oshirilayotgan ishlar alohida ahamiyat ega. "Jizzax" erkin iqtisodiy zonasida Xitoy Xalq Respublikasi bilan hamkorlikda amalga oshirilgan investitiya loyihalari 


\begin{tabular}{|c|c|c|c|c|}
\hline $\mathbf{T} / \mathbf{r}$ & $\begin{array}{l}\text { Investitsiya loyihasi } \\
\text { nomi }\end{array}$ & $\begin{array}{l}\text { Faoliyat } \\
\text { yo`nalishi }\end{array}$ & $\begin{array}{c}\text { Loyiha } \\
\text { qiymati, } \\
\text { mln. AQSH } \\
\text { dollari }\end{array}$ & $\begin{array}{c}\text { Yaratilgan } \\
\text { ish o'rni } \\
\text { soni }\end{array}$ \\
\hline 1. & $\begin{array}{c}\text { "Quyosh issiqlik energiyasi” } \\
\text { MCHJ QK } \\
\end{array}$ & $\begin{array}{c}\text { yangi avlod quyosh } \\
\text { texnologiyalari } \\
\end{array}$ & 3,3 & 17 \\
\hline 2. & $\begin{array}{l}\text { "Yorqin chiroqlar" } \\
\text { MCHJ QK }\end{array}$ & svetodiod lampalar & 2,5 & 45 \\
\hline 3. & $\begin{array}{c}\text { “ZTT Telekom” } \\
\text { MCHJ QK }\end{array}$ & $\begin{array}{c}\text { axborot } \\
\text { kommunikatsiya } \\
\text { texnologiyalari }\end{array}$ & 0,5 & 15 \\
\hline 4. & $\begin{array}{c}\text { "Broandband Solution" MCHJ } \\
\text { QK }\end{array}$ & $\begin{array}{c}\text { telekommunikatsiya } \\
\text { asbob-uskunalari }\end{array}$ & 3,1 & 17 \\
\hline 5. & $\begin{array}{l}\text { "Smart Vision" } \\
\text { MCHJ QK } \\
\end{array}$ & $\begin{array}{c}\text { video va IP-telefon } \\
\text { apparatlari } \\
\end{array}$ & 1,0 & 11 \\
\hline 6. & $\begin{array}{c}\text { "Mingyuan Silu Industry" } \\
\text { MCHJ QK }\end{array}$ & $\begin{array}{l}\text { dekorativ } \\
\text { oynalar }\end{array}$ & 28,9 & 200 \\
\hline
\end{tabular}

Erkin iqtisodiy zona hududida faoliyat ko’rsatayotgan O’zbekiston-Xitoy qo`shma korxonalar mamlakatimiz iqtisodiyotining rivojlanishiga, ishlab chiqarish va eksport salohiyatining oshishiga o`z hissasini qo `shib kelmoqda. "Quyosh issiqlik energiyasi” MCHJ QK misolida aytadigan bo `lsak, ushbu korxona yuqori texnologiyalarga asoslangan yangi avlod quyosh isitish tizimlarini ishlab chiqarishga ixtisoslashgan. Buekologikjihatdantoza, iqtisodiyjihatdantejamkortexnologiyahisoblanadi.Kelgusida erkin iqtisodiy zonada quyoshdan elektr energiyasi olish uchun quyosh panellari, gelioqurilmalar ishlab chiqarish va bu orqali O'zbekistonda ham noan`anaviy va zamonaviy elektr energiya yo`nalishini yo'lga qo'yish ustuvor yo`nalishlardan biri hisoblanadi. Bu borada Xitoy boy tajribaga, ulkan salohiyatga ega ekanligini ta kidlashimiz lozim. "Jizzax" EIZ joylashgan hudud qulay iqtisodiy geografik o 'ringa, boy tabiiy resurslarga va malakali ishchi kuchiga ega. Shuni inobatga olgan holda bu yerga Xitoy investitsiyalarini jalb etishni yanada kengaytirish, bu boradagi hamkorlikning yangi yo`nalishlarini yo`lga qo'yish maqsadga muvofiqdir.

\section{Foydalanilgan adabiyotlar}

1. Jo 'rayev A. Erkin iqtisodiy zonalar tashkil etish. Bitiruv malakaviy ish. -T.: TMI, 2013. 2. Karimov D. O`zbekistonda erkin iqtisodiy hududlarni rivojlantirish istiqbollari. Magistrlik dissertatsiyasi.-T.: TMI, 2018.

Internet saytlari:

1. www.mift.uz -O`zbekiston Respublikasi Investitsiyalar va tashqi ssavdo vazirligi rasmiy sayti

2. www.mift.uz - O`zbekiston Respublikasi Investitsiyalar va tashqi ssavdo vazirligi rasmiy sayti ma`lumotlari 


\title{
IQTISODIYOTDA INNOVATSIYANING TUTGAN O'RNI
}

\author{
Yuldosheva Inoyat Zikriyayevna. \\ Toshkent Irrigatsiya va Qishloq Xo'jaligini \\ Mexanizatsiyalash Muhandislari instituti, katta o'qituvchi \\ Toshboltayeva Yulduz Abduqodir qizi \\ Toshkent Irrigatsiya va Qishloq Xo'jaligini \\ Mexanizatsiyalash Muhandislari instituti, talaba
}

\begin{abstract}
Annotatsiya: Bozor islohotlarining amalga oshirilishi mamlakatimizning a'zo bo'lishi, jahon iqtisodiy tizimining bilimlar va axborotlar rolining o'sishi tomon o'zgarishi, yangi texnologiyalar va kapital bozori o'rtasidagi aloqalar kuchayishi bilan mamlakatimiz iqtisodiyotining innovatsion rivojlanish yo'liga o'tishi dolzarb ahamyat kasb etmoqda.
\end{abstract}

Kalit so'zlar: zamonaviy iqtisodiyot, innovatsiya, axborot texnologiyalari, intetektual salohiyat, eksportimport masalalari, valyuta munosabatlari.

Hozirgi kunda jamiyat hayotida innovatsion sohaning jadal rivojlanishi iqtisodiyotda intelektual mahsulot axborot va ilmiy-texnik, innovatsion faoliyat ulushining o'sishi shunga olib keldiki innovatsiyalar xuddi foydali qazilmalar, ishlab chiqarish quvvatlari va inteluktual salohiyat kabi mamlakatning boyligi hisoblana boshladi. O‘zbekiston Respublikasi Prezidenti Shavkat Mirziyoyevning fkricha, innovatsiyalarsiz rivojlanib bolmaydi. Bu sohadagi o'zgarishlarni xalqimizga keng targ'ib qilmasak, odamlarda ko'nikma paydo qilmasak, bugungi davr shiddati, fan-texnikaning mislsiz yutuqlari bilan hamqadam bo'lolmaymiz. Shuning uchun ushbu faoliyatni zamon talablari darajasida rivojlantirish yangi vazirlik, qolaversa, ushbu markazning asosiy vazifasi bo'lishi kerak. Chindan ham xalqimiz dunyoqarashida innovatsiya muhitini yaratish eng muhim vazifadir. Innovatsiya bo'lmas ekan, hech bir sohada raqobat, rivojlanish bo'lmasligi tayindir. Milliy va xalqaro tajribadan ma'lumki, iqtisodiyot va jamiyatning taraqqiyot darajasi ko'p jihatdan innovatsion faoliyatga hamda innovatsion rivojlanish va novatorlik g'oyalarini qo'llabquvvatlashga ko'p jihatdan bog'liq. Binobarin, iqtisodiyotdagi samaradorlik ishlab chiqarishga innovatsion texnologiyalar va ixtirolarning joriy etilishi evaziga oshadi. Shu bois bugungi kunda innovatsiyalar har bir mamlakat iqtisodiyotining muhim tarkibiy qismiga aylangan. Zamonaviy sharoitlarda jahon fani va innovatsiya faoliyatining yutuqlaridan keng foydalanish jamiyat va davlat hayotining barcha sohalarini izchil va barqaror rivojlantirishning, mamlakatning munosib kelajagini barpo etishning muhim omili bo'lib bormoqda. Shu bilan birga, quyidagi tizimli

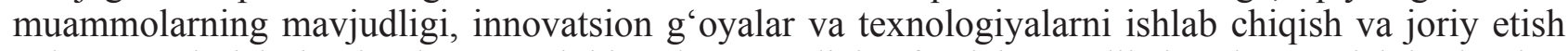
uchun mavjud imkoniyatlar va salohiyatdan yetarlicha foydalanmaslik ko'zlangan islohotlarning samarali amalga oshirilishiga hamda mamlakatning jadal innovatsion rivojlanishiga to'sqinlik qilmoqda. Yangilik ishlab chiqarish va boshqaruv tizimiga joriy qilingandan so 'ng bozorda iste'mol qilinadigan yangi mahsulotga aylanadi va uni sotishdan iqtisodiy, ijtimoiy yoki boshqa turdagi samaralar olinadi, - u yangi toifaga - innovatsiyalarga aylanadi. Umuman olganda, iqtisodiyotda innovatsiya tushunchasi va uning nazariy asoslari oldindan ma'lum bo'lgan. Masalan, "innovatsiya" tushunchasi birinchi b'lib fanga Avstriyalik (keyinchalik Amerikalik) olim Yozef Shumpeter $\mathrm{XX}$ asrning birinchi o'n yilligida kiritilgan. U o'zining "Iqtisodiy rivojlanish nazariyasi" nomli asarida (1911) Y.Shumpeter ilk bora innovatsiya masalalarini ko 'rib chiqdi va innovatsion jarayonga to 'liq tavsif berdi. Y.Shumpeter innovatsiyadagi 5 xil o'zgarishni ajratib ko'rsatdi:

1. yangi texnika va texnologik jarayonlar yoki ishlab chiqarishning yangicha bozor taminotidan foydalanish;

2. yangi xususiyatlarga ega bo'Igan mahsulot joriy qilish;

3. yangi xomashyodan foydalanish;

4. ishlab chiqarishni tahlil qilish va uning moddiy-texnika ta'minotida o'zgarishlar;

5. yangi sotuv bozorlarining paydo bo'lishi; U iqtisodiyotda innovator markaziy shaxsga aylanishini isbotlab bergan. Y.Shumpeterning fkricha innovatsiya bu - is'temol tovarlarining yangi turlari, yangi ishlab chiqarish va transport vositalari yangi bozorlar va sanoatda tashkilotlar shaklini joriy qilish va faoliyatda foydalanish maqsa-didagi o'zgarishlardir. Xalqaro standartlarga muvofq innovatsiya (yangilik kiritish) bozorda joriy qilingan yangi yoki takomillashtirilgan mahsulot, amaliy faoliyatda foydalaniladigan yangi yoki takomillashgan texnologik jarayon ko'rinishida yoki ijtimoiy 
xizmatlarga yangicha yondashuvda namoyon bo'ladigan innovatsion faoliyatning yakuniy natijasi sifatida tavsi?anadi. Innovatsion faoliyat yakunlangan ilmiy tadqiqot va loyihalar natijalari yoki boshqa ilmiy texnik yutuqlarni (fan-texnika yutuqlarini) yangi yoki takomillash tirilgan mahsulotga, bozorda sotiladigan, amaliy faoliyatda foydalaniladigan yangi yoki takomillashtirilgan texnologik jarayonga, shuningdek, shu bilan bo'g'liq qo'shimcha ilmiy tadqiqot va loyihalarga joriy qilishga yo"naltiril-gan jarayondir.

Shunday qilib, innovatsiya iqtisodiy qudratni yuksaltiruvchi asosiy omil sifatida qaraladi. Darhaqiqat, har qanday iqtisodiyotni, ayniqsa, uning muhim tarmog'i bo'lgan sanoat sohasini taraqqiy toptirish yangi texnologiyalarni joriy etishni taqozo qiladi. Chunki, bu mahsulot yoki xizmatning ichki va jahon bozorlaridagi raqobatbardoshligini taminlovchi omildir. Yana shuni ham takidlash joizki, mamlakatimiz birinchi Prezidentining farmon va qarorlarida belgilangan vazifalarga asoslangan fan va texnolo-giyalar taraqqiyotining 2012-2021 yillarga mo'ljallangan ustuvor yo'nalishlari respublikamiz iqtisodiyoti tarmoqlaridagi yechimini kutayotgan mavjud muammolarni hal qilishni, iqtisodiy rivojlanishda fan va ishlab chiqarish o'rtasidagi mutanosiblikni va innovatsiya faoliyatini ustuvor rivojlantirishni nazarda tutgan holda shakllantirildi. Innovatsiyalarni yaratish, tarqatish va hayotga tadbiq qilish uchun iqtisodiyotning turli sektorlarida ijobiy ishchanlik muhitini hosil qilish juda muhimdir. Buning uchun mamlakatda biznes yuritish qulay bo'lishi va iqtisodiyot shaffof hamda raqobatbardosh bo'lishi talab qilinadi. Shu jumladan, O'zbekistonda innovatsion o'zgarishlarni jadallashtirish uchun eksport-import operatsiyalariga, soliqqa tortishga oid qonunlarga va valyuta bilan ishlash bo'yicha tartib-qoidalarga tegishli o'zgartirishlar qilish maqsadga muvofq bo'ladi. Xalqaro savdo uchun yaxshi sharoitlar yaratilishi nafaqat mamlakatdagi biznes muhitini yaxshilash, balki boshqa mamlakatlardan texnologiyalar transferi va zamonaviy bilimlar tarqalishi uchun ham o'ta muhimdir. So'ngi yillarda, mamlakatimizda qisqa muddatda innovatsiyaga yo"naltirilgan iqtisodiyotni shakllantirishga va innovatsiyalarni keng joriy etish uchun shartsharoitlar yaratishga qaratilgan keng ko'lamli ishlar amalga oshirilmoqda.

Respublikani innovatsion va ilmiy-texnik rivojlantirish sohasida yagona davlat siyosatini amalgaoshiruvchi organ tashkil etilganligi, uning huzurida innovatsion rivojlanish va novatorlik g'oyalarini qo'llab-quvvatlash jamg'armasi mazkur yo'nalishdagi muhim bosqichlardan biri bo'ldi. Innovatsiya faoliyatini davlat tomonidan tartibga solish mexanizmlarini tubdan takomillashtirib, iqtisodiyot tarmoqlari va sohalariga innovatsiyalarni yanada samarali joriy etish uchun shartsharoitlarni yaratilmoqda.

\section{Foydalanilgan adabiyotlar:}

1. O'zbekiston Respublikasini yanada rivojlantirish bo'yicha "xarakatlar strategiyasi” to 'g'risida O‘zbekiston Respublikasi qonun hujjatlari 2017 - y, 6-son.

2. Ishlab chiqarishni modårnizatsiyalash, tåxnik va tåxnologik qayta jihozlashni rag'batlantirishga oid qo'shimcha chora-tadbirlar to'g'risida O'zbekiston Respublikasi Prezidenti Farmoni. 2007 yil 14-mart.

3. A.V.Vaxabov, D.A.Tadjibayeva, Sh.X.Xajibakiyev "Jahon iqtisodiyoti va xalqaro iqtisodiy munosabatlar" Toshkent -2015.

4. "Kichik biznes va innovatsiyalar" moliya ilmiy jurnali,T.: TMI,4/2014.

5. O'zbekiston iqtisodiyoti tarmoqlarida xorijiy investetsiyalarni o'zlashtirilishi va istiqbollari. B.Mamatov, K. D.Sharifxo“jayeva. 


\title{
MILLIY IQTISODIYOTINING RAQOBATBARDOSHLIGINI OSHIRISHDA XORIJIY INVESTITSIYALARNING $\mathrm{O}^{\circ} \mathrm{RNI}$
}

\author{
Yuldosheva Inoyat Zikriyayevna. \\ Toshkent Irrigatsiya va Qishloq Xo“jaligini \\ Mexanizatsiyalash Muhandislari instituti, katta o'qituvchi \\ Xaytqulova Zulayxo Mirzaboy qizi. \\ Toshkent Irrigatsiya va Qishloq Xo‘jaligini \\ Mexanizatsiyalash Muhandislari instituti, talaba
}

\begin{abstract}
Annotatsiya: Ushbu maqolada xorijiy investitsiyalarning ahamiyati va ularni milliy iqtisodiyotni rivojlantirishdagi o'rni yoritilgan bo'lib, statistik ma'lumotlar asosida tahlil qilingan. Shuningdek, maqolada milliy iqtisodiyotga xorijiy investitsiyalarni jalb qilishda mavjud muammolar va ularni oldini olishni faollashtirishda qanday chora-tadbirlardan foydalanish kerakligi keng yoritilgan.

Kalit so'zlar: Investitsiya, xorijiy investitsiya, to ${ }^{6} g^{6}$ ridan-to' $\mathrm{g}^{6} \mathrm{ri}$ xorijiy investitsiya, portfel investitsiya, investor, kapital eksporti, ustav kapital, dividend, tadbirkorlik foydasi, eksport, import.
\end{abstract}

Xorijiy investitsiyalarni iqtisodiyotning ustuvor tarmoqlariga yo"naltirish va ularni samaradorligini aniq belgilash, ilmiy asoslangan investitsiya qarorlarini qabul qilish, investitsiya faoliyatini oqilona tartibga solish asosida tashqi moliyaviy manbalarining barcha shart-sharoitlarini hisobga olgan holda jalb qilish milliy iqtisodiyot tarmoqlari rivojlanishining kelajagini belgilaydi. Iqtisodiyot tarmoqlari uchun zarur chet el sarmoyalarini topish iqtisodiy o'sish shartiga aylangan. Ushbu mezonlarni O‘zbekiston milliy iqtisodiyotini isloh qilish va rivojlantirishning hozirgi bosqichida hisobga olinishi juda muhim ahamiyat kasb etadi. Uning asosiy vazifalari iqtisodiy o'sishning barqarorligini ta'minlashda eksport salohiyatining o'rnini, kichik biznes va xususiy tadbirkorlikning hissasini oshirish, erkinlashtirish jarayonlarini chuqurlashtirish va iqtisodiyotning ustuvor tarmoqlarini davlat tomonidan qo 'llab-quvvatlash samaradorligini oshirishdan iborat. O'zbekiston Respublikasi Prezidenti Shavkat Mirziyoyev tomonidan qabul qilingan "O'zbekiston Respublikasini yanada rivojlantirish bo 'yicha Harakatlar strategiyasi to'g'risida"gi Farmonida olib borilayotgan islohotlar samarasini yanada oshirish, davlat va jamiyatning har tomonlama va jadal rivojlanishi uchun shart sharoitlar yaratish, mamlakatimizni modernizatsiya qilish hamda hayotning barcha sohalarini liberallashtirish bo'yicha ustuvor yo'nalishlarni amalga oshirish maqsadida 2017-2021-yillarda O'zbekiston Respublikasini rivojlantishning beshta ustuvor yo"nalishi bo 'yicha Harakatlar strategiyasi tasdiqlandi - Ushbu Harakatlar strategiyasida iqtisodiyotni rivojlantirish va liberallashtirishning ustuvor yo"nalishlaridan biri bu - investitsiya muhitini takomillashtirish, mamlakat iqtisodiyoti tarmoqlari va hududlariga xorijiy, eng avvalo, to ' $g^{6}$ 'ridanto' $g^{6}$ ri xorijiy investitsiyalarni faol jalb qilishdan iborat. Shuning uchun ham, xorijiy investitsiyalarni jalb etmay, ayniqsa, yetakchi tarmoqlarda chet el investitsiyalari ishtirokini kengaytirmay turib, iqtisodiyotda tarkibiy o'zgarishlarni amalga oshirish va uni modernizatsiya qilish, korxonalarni zamonaviy texnika bilan qayta jihozlash hamda raqobatdosh mahsulotni ishlab chiqarishni yo'lga qo 'yish mumkin emas. Mamlakatimiz iqtisodiyotiga xorijiy investitsiyalarning jalb etilishi uning iqtisodiy imkoniyatlarining kengayishini tezlashtirib, barcha sohalarda ichki imkoniyat va rezervlarni ishga solish, yangi texnika va texnologiya, eksportbop tovarlarni o'zlashtirish, ularni ishlab chiqarishni yo'lga qo'yish orqali davlatimiz iqtisodiy qudratini ta'minlashda muhim ahamiyat kasb etadi. Investitsiyalarning milliy iqtisodiyotga keng miqyosda jalb etish o'tish davrining strategik va joriy vazifalarini hal etish zaruriyati bilan bog'liq. Ushbu vazifalarni bajarish natijasida o'tgan yillarda investitsiyalarning o'sishi jadallashdi. 
1-jadval. O’zbekiston Respublikasi yalpi ichki mahsuloti va investitsiyalar o'sish sur'atlarining $0^{6}$ zgarishi.

\begin{tabular}{|c|c|c|c|c|}
\hline Yillar & $\begin{array}{c}\text { Yalpi ichki } \\
\text { mahsulot, } \\
\text { (mlrd. AQSh } \\
\text { dollari) }\end{array}$ & $\begin{array}{c}\text { Oldingi } \\
\text { yilga } \\
\text { nisbatan \% } \\
\text { da }\end{array}$ & $\begin{array}{c}\text { Investitsiyalar, } \\
\text { (mIrd. AQSh } \\
\text { dollari) }\end{array}$ & $\begin{array}{c}\text { Oldingi yilga } \\
\text { nisbatan \% } \\
\text { da }\end{array}$ \\
\hline $\mathbf{2 0 1 3}$ & 47,2 & 108,0 & 13,0 & 111,3 \\
$\mathbf{2 0 1 4}$ & 51,1 & 108,1 & 14,6 & 110,9 \\
\hline $\mathbf{2 0 1 5}$ & 55,2 & 108,0 & 15,8 & 109,5 \\
\hline $\mathbf{2 0 1 6}$ & 59,5 & 107,8 & 16,6 & 109,6 \\
\hline $\mathbf{2 0 1 7}$ & 48,7 & 105,3 & 11,9 & 109 \\
\hline
\end{tabular}

Yuqoridagi jadvalda ko'rinib turibdiki, respublikamizda YaIMning o'sishi yuqori darajadadir. 2017 yilda YaIM 48,7 mlrd. AQSh dollarini tashkil etgan bo'lsa, bu 2016 yilga nisbatan 5,3 foizga o'sgan. Bunday natijaga erishishda, investitsiyalar oqimining ko'payishi muhim rol o'ynaydi, e’tibor qaratadigan bo'lsak, 2017 yilda mamlakatimizga 11,9 milliard AQSh dollarida investitsiya jalb etilgan bo'lsa, bu ko'rsatkich 2016 yilga nisbatan salkam 9,7 foizga o'sgan. 2017 yilda 17146,5 mlrd. so'm (dollar ekvivalentida 3348,2 mln. AQSh dollari) yoki o'tgan yilga nisbatan 134,9 foiz asosiy kapitalga xorijiy investitsiya va kreditlar o'zlashtirildi. Asosiy kapitalga xorijiy investitsiyalarning YaIMdagi ulushi 2017 yilda 6,7 foizni tashkil etib, o'tgan yilga nisbatan 1,4 foizga ko'paydi.

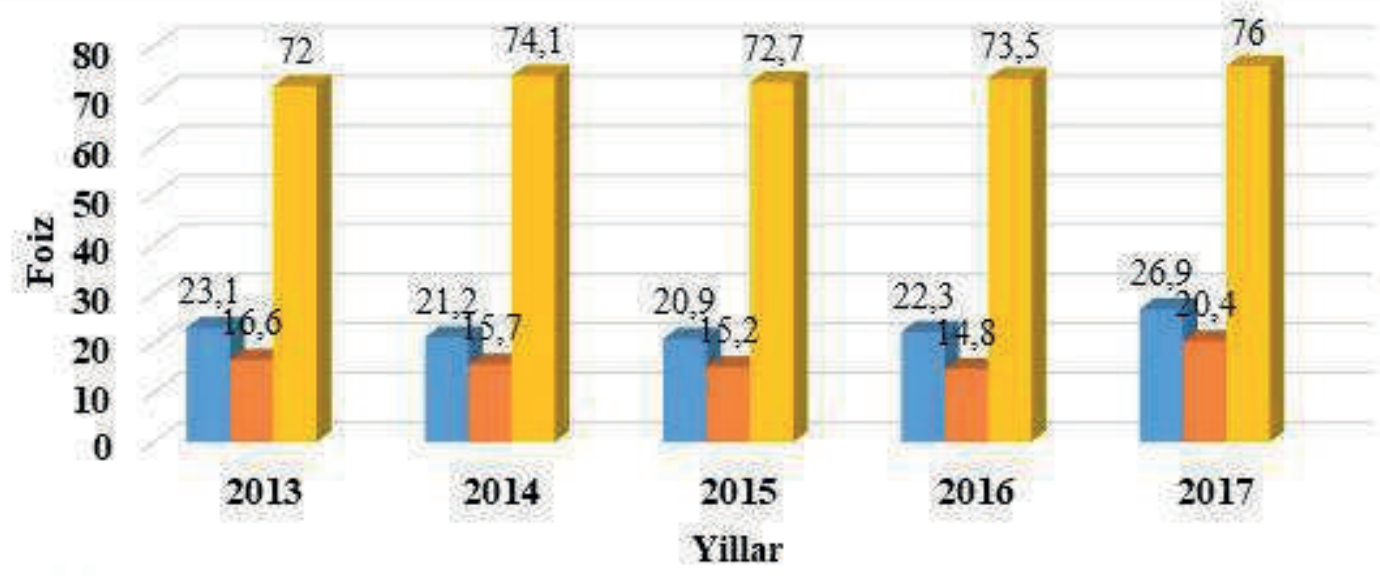

Jami investitsiyalar tarkibida xorijiy investitsiyalarning ulushi, \%

Jami investitsiy alar tarkibida to' g'ridan-to'g'ri xorijiy investitsiy alarning ulushi, \%

Jami xorijiy investitsiyalar tarkibida to'g'ridan-to'g'ri xorijiy investitsiy alarning ulushi, \%

1-rasm. Xorijiy investitsiyalarni iqtisodiyotga jalb qilish dinamikasi (\% hisobida) 1-rasmda xorijiy investitsiyalarni iqtisodiyotga jalb qilish dinamikasi (\% hisobida) berilgan bo'lib, 2017 yilda jami investitsiyalar tarkibida xorijiy investitsiyalar 26,9 foizni tashkil etib, 2016 yilga nisbatan 4,6 foizga o'sgan. Shuningdek, 2017 yilda jami investitsiyalar tarkibida to'g'ridan-to' $g$ 'ri investitsiyalar ulushi 20,4 foizni tashkil etgan holda, jami xorijiy investitsiyalar tarkibida esa 76 foizni tashkil etdi. Shuningdek, besh yil mobaynida jami investitsiyalar tarkibida xorijiy investitsiyalarni 3,8 foizga o'sganini ko'rishimiz mumkin. Jami xorijiy investitsiyalar tarkibida to ${ }^{6}{ }^{6}$ 'ridan-to ${ }^{6}{ }^{6}$ 'ri xorijiy investitsiyalar esa so'nggi besh yil ichida 3,8 foizga o'sgan. Ammo 2013 yilga nisbatan 2016 yilda jami investitsiyalar ulushi 16,6 foizdan 14,8 foizga kamaydi. Xorijiy investitsiyalar ishtirokidagi yangi korxonalar sonining tobora ortib borishi va yangilari barpo etilayotgani davlatimizning bu sohaga bo'lgan katta e'tibori va ularga yaratib berayotgan qulayliklari natijasidir. Shu boisdan ham mamlakatimizga xorijiy sarmoyalarni jalb etayotgan korxonalarni iqtisodiy rag'batlantirish va ular uchun zarur sharoitlarni yaratib berish o'ta muhim masalalardan biri hisoblanadi. Shuning uchun 
ham milliy iqtisodiyotimizga xorijiy investitsiyalarni jalb qilishni faollashtirishda quyidagi choratadbirlarni amalga oshirish zarur:

birinchidan, investitsiyalarni jalb etish va o'zlashtirish bo'yicha meyoriy-huquqiy bazani doimiy ravishda takomillashtirish;

ikkinchidan, hududlar investitsion jozibadorligini oshirishi bo'yicha qo'shimcha chora-tadbirlar ishlab chiqish;

uchinchidan, investitsiya jalb qilish uchun xalqaro me'yorlar va konvensiyalarga mos keladigan, sanoati rivojlangan mamlakatlar investorlari tomonidan tan olinadigan huquqiy shart-sharoitlarni yaratishga doimiy intilish va ilg'or xalqaro tajribalardan foydalanish;

to'rtinchidan, inflyatsiya darajasini investitsion loyihalar qiymat o'sishiga ta'sirini kamaytirish, shuningdek, xorijiy investitsiyalar hajmini yanada ko'paytirish;

beshinchidan, investitsiyalarni real ishlab chiqarish sohasiga, ya'ni xom-ashyoni qayta ishlovchi tarmoqlarga jalb etish;

oltinchidan, chet el investorlariga yanada qulay investitsiya muhitini yaratish maqsadida rag 'batlantirish tizimini yanada takomillashtirish, xususan, soliq yukini kamaytirish va soliq tizimini investorlar uchun ham soddalashtirish;

yettinchidan, xorijiy iqtisodiy sub'ektlar bilan o'zaro manfaatli loyihalarni amalga oshirish tizimini takomillashtirish va ular bilan erkin investitsion iqtisodiy zonalarni tashkil etish lozim.

Yuqoridagi takliflarni amaliyotda joriy etish milliy iqtisodiyotimizga xorijiy investitsiyalarni jalb etishni yanada faollashtirishga ijobiy ta'sir ko'rsatadi. Ushbu holat pirovardida ishlab chiqarishni texnik va texnologik jihatdan uzluksiz yangilab borish, iqtisodiyotda chuqur tarkibiy o'zgarishlarni amalga oshirish, sanoatni modernizatsiya va diversifikatsiya qilishni izchil davom ettirish asosida, kelgusida mamlakatimizda investitsion siyosatni to 'liq amalga oshirish imkoniyatini yaratadi.

\section{Foydalanilgan adabiyotlar ro' $^{6}$ xati}

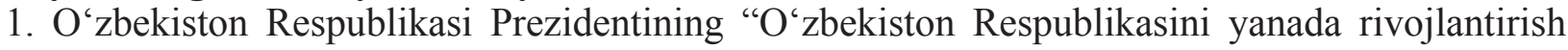
bo ‘yicha Harakatlar strategiyasi to'g'risida”gi PF-4947-son Farmoni. 2017 yil 7 fevral.

2. G'ozibekov D., Nosirov E. O‘zbekiston iqtisodiyotiga xorijiy investitsiyalarni jalb qilish. Risola. - T.: "Iqtisod-moliya", 2007.

3. “2017-2021 yillarda O‘zbekiston Respublikasini rivojlantirishning beshta ustuvor yo'nalishi bo “yicha Harakatlar strategiyasini "Xalq bilan muloqot va inson manfaatlari yili" da amalga oshirishga oid Davlat dasturini o'rganish bo'yicha" ilmiy-uslubiy risola. - T.: "Ma'naviyat", 2017.

4. O'zbekiston Respublikasi Davlat Statistika qo'mitasi veb sayti: www.stat.uz 


\section{АБУ БАРАКОТ НАСАФИЙ БУЮК ХАНАФИЙ ФАҚИХИ}

Ахмедов Сайқал Абдурохмонович 24.00. 03 - Фиқх, калом илми. Илохиёт ихтисослиги, 1 босқич докторант Тел:998901158607; ahmedov1981@gmail.com

Насафдан етишиб чиққан забардаст олимлардан бири Абул Баракот Насафий бўлиб, у ислом илмларининг деярли барча сохаларида сермахсул ва барча томонидан ижобий қабул этилган ижоди билан машхур бўлди. Абу Барокат Абдуллох ибн Ахмад ибн Мухаммад аннасафий хижрий 710. милодий 1310 йил Қашқадарёнинг Насаф шахрида таваллуд топган. Худди шундай. Бу ердан ханафий мазхабининг йирик вакиллари Абу Мутиъ Макхул Насафий (ваф. 318/930), Нажмуддин Абу Хафс Умар Насафий (1070-1143), Абулфазл Мухаммад Бурхон Насафий (600-679/1201-1281), Абу Али Хусайн Насафий (ваф. 424/1034)лар каби буюк алломалар ютишиб чикди.

Абул Баракот Насафий уламолар томонидан “Хофизуд-дин”, яъни “динни химоя қилувчи” деган шарафли номга сазовор бўлган. Абдухай Лакнавийнинг гувохлик беришича, бундай номга фақат икки киши лойиқ кўрилган бўлиб, уларнинг иккиси хам Бухорода мўғуллар босқини даврида илм тарқатган Шамсул-аимма Мухаммад ибн Абдуссаттор Кардарий (ваф. 642/1244)нинг изидан борган шогирдлари Абул Баракот Насафий ва Абул-Фазл Мухаммад Кабир Бухорийлардир ${ }^{1}$.

У ислом илмлари борасида тафсир, калом ва фиқх илмларида бир қатор китоблар ёзган. У адабиётларда қуйидагича тавсифланган:

«Шайх, улуғ имом, пешқадам аллома, Ер ахлининг устози, суннат ва фарзни жонлантирувчи, Қуръон маъноларини кашф қилувчи, таъвилнинг нозик жихатларини билувчи, илохий калом таржимони, маъоний ва баён илмлари сохиби, фиқх ва усул ал-фиқхнинг билимдони, ақлий ва нақлий масалаларнинг таянчи, дин ва миллат химоячиси, ислом ва мусулмонлар етакчиси, пайғамбарлар илмларининг меросхўри, етук мужтахид, мухаққиқ олимларнинг машхури» ${ }^{2}$.

Аллома асосан Бухорода таълим олган, ёшлик даври диний-илмий мухитда ўтган, илм талабида кўплаб мамлакатларга борган ва катта обрў-эътибор топган. Абу баракот насафий ўз даврининг пеш қадам устозларидан бўлиб тахминан 1280 йилларда Кирмон шахридаги «ал-Қутбийа ас-султония» мадрасасида мударрислик қилган. Сўнг, Бағдодга келиб, у ерда талабаларга Мотуридий, Бурхониддин Марғиноний ва ўз асарларидан таълим берган. Шу каби бир қанча асарларига шархлар ёзган.

Насафий зохид ва диёнатли бўлиб, араб ва форс тилларини пухта ўрганган. Абдулхай Лакнавий алломани «замонасида тенги йўқ комил имом, фиқх ва усул ал-фиқх олимларининг етакчиси, хадис ва унинг маъноларида ўткир олим бўлган» ${ }^{3}$, Ибн Хажар Асқалоний (773/1372-852/1449) эса «алломаи дунё», деб таърифлаган.

У ханафий фиқхида буюк олломаларидан бўлиб “Канзу Дақоиқ”, “ал-Манор” ва “алВофи” каби китоблар ёзиб сўнгра унинг ўзи “ал-Вофи” асарига “ал-Кофи” номли шарх ёзган.

Абу Барокат Абдуллох ибн Ахмад ибн Мухаммад ан-насафий ханафий фиқхи борасида кийинги асрда энг мутабар китоблардан бири саналган "Канзу ад-дақоиқ” ва "ал-Вафи” китоблари олимлар орасида машхур бўлган. Хозиргача алломанинг “Канзу ад-Дақоиқ” китоби устоз ва шогирдлар ўртасида жуда катта қизиқиш билан истифода қилиб келинмоқда. Буюк ханафий олими Имом Фахриддин Зайлаъий бу китоб хақида илиқ фикр айтиб ханафий

\footnotetext{
1 Самъоний Абу Саъд Абдукарим ибн Мухаммад ибн Мансур ат-Тамимий. Ал-Ансоб. 5 жилдли. Абдуллох Умар ал-Борудий тахрири остида. - Байрут: Дор ал-фикр, 1998. Ж. 5. - Б. 173.

2 Қаранг: Абул Баракот Насафий. Мадорикут-танзкл ва хақоиқут-тавил. ЎзР ФА ШИ кўлёзмалар фонди, инв. № 2583/I. - Б. 1ㅎ.; Абул Баракот Насафий. Ал-Кофи шархул-Вофи. ЎзР ФА ШИ кўлёзмалар фонди, инв. № 3110/І. - Б. $1^{\sigma}$.

3 Абдулхай Лакнавий. Ал-Фавоидул-бахийа. - Байрут: Дорул-кутубил-илмия, 1998. - Б. 291.
} 
фиқхидаги энг гўзал фойдали мухтасар китоб экан деб айтиб ўтган.

Аллома ўзининг “ал-Вофий” китобида ушбу китобни ёзишлигига нима туртки бўлганини ва асарнинг ўзигахос услубини куйидагича келтириб ўтади:

“Фикру хаёлимни ал-Жоми ас-соғир, Зиёдат, Мухтасар ва Назму ал-хилофиятда келган масалаларини кенг қамраб олувчи бир китоб ёзиш чулғаб олган эди”.

Шунга кўра буюк аллома Имом насафий ал-Вофий асарини ханафий мазхабидаги уч асос китобларини ва булардан ташқари Имом Мухаммад ибн Ахмад ибн Жаъфар Хамадоннинг “Мухтасар ал-Қудурий” ва Имом Абу Хафс Умар ибн Мухаммад ан-насафий ал-ханафийнинг "Манзумат ал-хилофиёт" асрлар сосида ёзиб унга баъзи-бир фатво масалаларини хам келтириб ўтган. Ушбу мухтасар китоб қирқ мингта масъалани мухтасар ва тадқиқ қилган холда ўз ичига олган. Бу китоб ханафий фиқхининг энг мутабар китобларидан хисобланади.

Олим бу китобидаги барча масъалаларни Имом Абу Ханифанинг фикрига таяниб айтиб ўтган, фақат ўнтага яқин масъалалардагина Имомнинг шогирдларини фикрига таяниб масъала келтирган. 


\title{
ТУРКИСТОНДА ҚЎРБОШИЛАРИ ФАОЛИЯТИ ВА УЛАРНИНГ КЕЙИНГИ ТАКДИРИ.
}

\author{
Дилмурод Холлиев, Рахматова Дилбар \\ (ҚарДу) талабалари
}

Ўзбекистоннинг советлар даври тарихи машаққатли, оғир синов ва кураш йўлларидан иборатдир. Бу деярли ўрганилмаган тарихий давр 1918-1934-йиллар халқимизнинг Ватан, миллий озодлиги йўлида олиб борган миллийуруш, истиқлолчилик харакати. Бу хаёт ва мамот учун кураш жараёнида халқ орасидан кўплаб жасур саркардалар, кўмондонлар, кўрбошиларнинг бутун бир авлоди етишиб чикди.

Шўролар даврида уларнинг барчасига халқ душмани деган тамға ёпиштирилган, улар хақида бирор оғиз ижобий сўз айтишнинг мутлақо имкони бўлмаган, аксинча улар керагича ёмонга чиқарилган, чин тарих ўрнини ёлғон тарих эгаллаган эди". Бу даврни Алихонтўра Соғуний (1885-1976) шундай тилга олади: “Дахрийлар давлатининг бошланғич даври 1918 йилдан 1925-йил орасида бутун Ўзбекистон ўлкалари бўйича “босмачи”лар отидан кўпаймиш қўзғолончилар кўпаймиш эди. Буларнинг энг машхурлари эса Хўқандда Эргаш; Марғилонда Мадаминбек, Шерматбек; Андижон, Ўш, Ўзгантомонларда Холхўжа, Охунжон, Абдураззоқ; Наманганда Омон Полвон вабошқалар эди."2.

Биринчи Президентимиз таъкидлаганидек, “бундан бир юз ўттиз йил муқаддам халқимиз миллий мустақиллиги ва тарихий давлатчилигини йўқотиб, мустамлака асоратига тушиб қолган эди. ”Шу давр мобайнида аждодларимиз, миллатимиз машаққатлисинов вакураш йўлларини босиб ўтди․

Бу миллий харакатнинг бош қўмондонларидан бири Шермухаммадбекнинг айтишича: "Босмачилик умум Туркистон истиқлоли учун бир ёқадан бош чиқарган ватанпарварларнинг харакатидир. Бу харакат Чингизийларнинг, Темурийларнинг, Улуғбекларнинг, Навоийларнинг юртини Москов тахдидидан халос этиш демакдир"4.

Ўша давр воқеалари гувохи бўлган Алихонтўра Соғуний воқеани шундай тавсифлайди:

“Бизнинг бу сафаримиз 1921 йили бўлганликдан “босмачи” номидаги қўзғолончиларининг энг кучайиб кетган вақти эди. Бир қишлоқда большевиклар, иккинчисида “босмачи”лар туриб, ораларида отишма-чопишмалардан чиққанмилтиқ товушлариузилмас эди"5.

Ўрта Осиёда фаолият кўрсатган қўрбошиларнинг харакатлантирувчи кучи ва уларнинг етакчиси, том маънода қўрбошиларнинг энг йириги Мадаминбек эди. Мадаминбекнинг фожеасига доир аниқ тарихий фактлар мавжуд эмас. Лекин турли хил тахминлар ва илмий асослар бор.

“Шермат қўрбоши Қўшоқвой хожи ўғли (1893-1970) Туркистонда совет режимига қарши қуролли харакат намояндаларидан бири (1918-1922), Туркистон-турк мустақил ислом жумхурияти раиси (1920-1922).

Қизил армия томонидан Туркистон минтақасига катта харбий қисмлар ташлангач, Шермухаммадбек Фарғона водийсини тарк этиб (1922 йил. 30 декабрь), укаси Нурмухаммадбек ва кўрбоши Тўхтасин Мақсуд билан 450-500 кишилик харбий гурухга бошчилик қилган холатда дастлаб БХСР худудига, 1923 йил бахорида эса Афғонистонга ўтиб кетган ва Қобулда яшаган. У Афғонистондан кичик кўшин билан Вахш дарёси орқали Шарқий Бухорога ўтмоқчи бўлганида совет авиацияси ёрдамида ортга қайтарилган (1929 йил 15 апрель). Кобул хукумати 2-жахон уруши даврида Шермухаммадбекни 2 йилга (1943-1945) қамоқда ушлаб турган. Шермухаммадбек озодликка чиққач, Хиндистон, сўнгра Покистоннинг Пешовар (1951-1955) ва Туркиянинг Адана (1955 йилдан умрининг охиригача) шахарларида яшаган. Адана шахрида дафн қилинган. Шермухаммадбек совет режими даврида «Кўршермат» деб тахқирланган ва

\footnotetext{
МансурхўжаХўжаев,Шермухаммадбекқўрбоши. Шарқ. Т:, 2008,Б. 5.

АлихонтўраСоғуний, ТуркистонҚайғуси. 1966-1973. В. 28.

3 И.А.Каримов, Жамиятимизмафкураси халқнихалқ,миллатнимиллат қилишгахизматэтсин. Т:, Ўзбекистон.

${ }^{4}$ Иркаев.М,История гражданской войны в Таджикистане.Душанбе, 1963. Б. 328-329.

5 АлихонтўраСоғуний, Кўрсатилганасар. Б. 26.
} 1998. Б. 3. 
унинг жанговар фаолияти сохталаштирилган"1.

“Жанглардан бирида Шермухаммадбекнинг бешотар милтиғи лўкидони (затвори) яхши ишламай қолди. Шермухаммадбек милтиқни яқинроқ ушлаб, лўкидонни текшириб турган эди, лўкидон яна ишлаб қолиб, ўқ отилиб кетди. Бошқа милтиқлар каби, бешотар кўндоғи хам елкага тираб туриб отиш учун, ярим ой шаклида тугалланган бўлади. Лўкидон ишлаб кетиб, ўқ отилгач, тепки зарбидан ярим ой шаклидаги қўндоқнинг бир учи Шермухаммадбекнинг чап кўзига тегди ва уни отдан ағдариб юборди. Шужангдаучапкўзиданажралади.Шундан бери Шермухаммадбекка унинг душманлари “Кўршермат” деган ном кўйиб олдилар.

Таассуфлар бўлгайки, кейинроқ “Кўршермат” деган ном "Шермухаммадбек” деган номни халқ лафзидан сиқиб чиқараёзди. Юқорида келтирилганидек, “Кўршермат” демаса уни биров танимайдиган бўлиб қолди. Ўшандан бери Шермухаммадбек кўзига кўзбанд боғлаб юрди. Кейинроқ эса, унинг қўшинига харбий мутахассис сифатида келган турк зобитлари унга қора кўзойнак совға қилдилар"2.

Хулоса ўрнида шуни айтиш керакки, бундан юз йил муқаддам мамлакатимиз худудида рўй берган воқеалар, шунингдек ватан озодлиги йўлида курашган курашчилар тақдири уларнинг мақсадлари, режалари, базан ачинарли, базан эса фожеали тугаган такдирларига тарих гувох.

${ }^{1}$ МансурхўжаХўжаев, Кўрсатилган асар. Б. 288.

2 МансурхўжаХўжаев, Кўрсатилган асар. Б. 103. 


\title{
ЎЗБЕКИСТОН РЕСПУБЛИКАСИ ОЛИЙ ТАЬЛИМ ТИЗИМИНИ ИСЛОХ ҚИЛИШДА ТЕМПУС ДАСТУРИНИНГ ИШТИРОКИ
}

Тоштемиров Достон Дилшод ўғли Мирзо Улуғбек номидаги ЎММ Тарих факультети 1 курс магистранти dtoshtemirov271@gmail.com +998993300956

Аннотация: Мақолада Темпус -Тасис дастурининг Ўзбекистонда олий таълим тизимини ислох қилишга кўмаклашиш, республика олий таълим муассасалари ва Европа Иттифоқи олий ўқув юртлари ўртасида хамкорликни ривожлантиришга қаратилган дастурини амалда рўёбга чиқариш жараёни очиб берилади. Унда ўкув дастурларини ишлаб чиқиш ва ўқув материалларини тайёрлаш, олий ўқув юртларида менежмент тизимини такомиллаштириш хамда талабалар ва педагогларларнинг харакатчанлигига кўмаклашиш бўйича ТЕМПУС фаолияти тахлил қилинган.

Калит сўзлар: Олий таълим, Европа Иттифоқи, Темпус-Тасис дастури, олий таълим бошқаруви, ўзаро хамкорлик. қўшма лойихалар, икки босқичли олий таълим, таълим сифати.

\section{PARTICIPATION OF THE TEMPUS PROGRAM IN THE REFORM OF HIGHER EDUCATION IN THE REPUBLIC OF UZBEKISTAN}

Toshtemirov Doston Dilshod o'g'li

1 st year master of the faculty of

History of The National University of Uzbekistan named after Mirzo Ulukhbek

Annotation: The article develops the practical implementation of TACIS s TEMPUS Program in Uzbekistan, which is aimed at rending assistance tor reforming the system of higher education and development of cooperation between higher education institutions ot our republic and higher education institutions of European Union. It analyses the TEMPUS activities in developing of the curriculums and preparation of the educational materials, in improvement of the management system in the higher education institutions as well as in assistance of mobility of the students and lecturers.

Keywords: Higher Education, EU, Tempus-Tacis Program, Higher Education Management, Cooperation. joint projects, two-stage higher education, quality of education.

\section{УЧАСТИЕ ПРОГРАММЫ ТЕМРUS В РЕФОРМИРОВАНИИ СИСТЕМЫ ВЫСШЕГО ОБРАЗОВАНИЯ РЕСПУБЛИКИ УЗБЕКИСТАН}

Тоштемиров Достон Дилшод огли

Магистр 1 курса исторического факультета Национального университета Узбекистана имени Мирзо Улугбека

\begin{abstract}
Аннотация: В статье раскрывается практическая реализация программы TACIS TEMPUS в Узбекистане, которая направлена на оказание помощи в реформировании системы высшего образования и развитии сотрудничества между высшими учебными заведениями нашей республики и высшими учебными заведениями Европейского Союза. В нем анализируется деятельность TEMPUS по разработке учебных программ и подготовке учебных материалов, по совершенствованию системы управления в высших учебных заведениях, а также по содействию мобильности студентов и преподавателей.

Ключевые слова: высшее образование, EC, программа Tempus-Tacis, управление высшим образованием, сотрудничество. совместные проекты, двухступенчатое высшее образование, качество образования.
\end{abstract}

Мустақилликнинг биринчи кунидан бошлаб Ўзбекистон Республикаси таьлим сохасини устувор йўналиш сифатида танлади ва шу кунгача шундай бўлиб қолмоқда. 30 йиллик мустақил тараққиёт давомида Ўзбекистон Республикаси таьлим тизимида таркибий ва маз- 
мунан туб ислохотлар амалга оширилди. ${ }^{1}$

Ўзбекистонда мустақиллик йилларида амалга оширилган ислохотларнинг асосий мақсади республикамиздаги таълим тизимини сиёсий, иқтисодий, ижтимоий ва маданий ривожланишининг ўзига хос хусусиятларини хисобга олган холда дунёда тан олинган стандартларга мувофиқлигини таъминлашдан иборат.

Белгиланган вазифаларни бажариш учун таьлим ва маданий ривожланиш сохасида илғор технологиялар ва ўқув тизимларидан фойдаланиш, ўрганиш катта ахамиятга эгадир. Европа мамлакатлари университетлари билан хамкорлик алоқаларини ўрнатиш ва ривожлантиришда Темпус дастурининг ахамияти катта эканлигини такидлаш керак.

Темпус - Европа Иттифоқининг Ғарбий Европа Болқон, Шарқий Европа хамда Марказий Осиё, Шимолий Африка ва Яқин Шарқдаги шерик мамлакатларидаги олий таълим тизимларини модернизациялашни қўллаб-қувватлаш дастури хисобланади. Дастур Европа Иттифоқи ва унинг атрофидаги шерик-давлатлар ўртасида олий таълим сохасида хамкорлик учун шароит яратишга ёрдам беради.

Тасис дастурининг бир қисми бўлган Темпус дастури Ўзбекистондаги олий таълим тизимини ислох қилиш ва республика университетлари билан Европа Иттифоқи университетлари ўртасидаги хамкорликни ривожлантиришга қаратилган. Бундай лойихаларнинг мақсади ўқув дастурларини ишлаб чиқиш ва ўқув материалларини тайёрлаш, университетларда бошқарув тизимини такомиллаштириш, шунингдек талабалар ва ўқитувчиларнинг харакатчанлигини таъминлашдир ${ }^{2}$.

Ўзбекистон 1994 йилда Тасис дастури бўйича Темпус дастурига қўшилган давлатлар қаторига кўшилди. Республикада дастурнинг фаолияти Темпус Тасис дастурининг 6 та дастлабки лойихаларини амалга ошириш билан бошланди. Республиканинг барча олий ўқув юртлари, шунингдек лойиханинг мақсадларига мувофиқ университетларнинг шериклари деб белгиланган муассасалар ва ташкилотлар Темпус Тасис дастурида қатнашиш хуқуқига эга бўлди.

Лойиханинг биринчи даври 1994-1996 йилларни ўз ичига олиб Ўзбекистонда 1994 йилда дастлабки олтита лойиханинг бошланиши билан ажралиб туради. Темпус I ни амалга ошириш даврида СамДУда «Урбалайф» каби дастлабки лойихалар амалга оширилди; ТДИУ да “Эхтиёжларни бахолаш, ўқув дастурлари ва ўкув курсларини ислох қилиш", ТДАУ да «Қишлоқ хўжалиги иқтисодиёти ўкув дастурларини таркибий қайта куриш» ва бошқалар амалга оширилди ${ }^{3}$.

Тошкент давлат университетининг тарих факультетида “Тарихни ўқитиш ва ўрганиш тизимини қайта қуриш" лойихаси амалга оширилди. Дастлабки «Тарих» лойихаси Европа Комиссияси томонидан маъкулланди ва Европанинг кўшма лойихасида давом этди. Лойихани амалга ошириш учун Европа Иттифоқидан 747,867 ЭКЮ миқдорида грант олинди ${ }^{4}$.

Амалга оширилган лойиханинг мақсади таьлим жараёнини қайта қуриш ва республикада олий ўқув юртларида янги тарих курсларини тайёрлаш хамда ўқитувчиларни малака оширишига қаратилган эди. Лойиха доирасида бакалавриат талабалари, магистрантлар ва профессор-ўқитувчилар учун ўқув сафарлари ташкил этилди. Шунингдек лойиха доирасида Тарих факультети учун тегишли илмий адабиётлар ва бошқалар сотиб олинди.

Сотиб олинган босмахона ускуналари дарсликлар ва ресурс материалларини ишлаб чиқаришда ёрдам берди. Факультетнинг 80 дан ортиқ талабалари, аспирантлари ва ўқитувчилари Европа университетларида амалиёт ва малака оширдилар. Бундан ташқари, тарих факультетида замонавий технологиялар билан жихозланган Ресурс маркази ташкил этилди ва Ғарбий Европани ўрганиш маркази ташкил этилди.

Шунингдек лойиха ўзбек ва ғарб олимлари ўртасида яқин алоқалар ва ўзаро илмий алмашинувни ривожлантиришга хизмат қилди.

«Тарих» Европа қўшма лойихаси хукумат, илмий ва жамоат муассасалари томонидан кенг ва самарали кўмак олди, оммавий ахборот воситаларида бир неча бор ёритилди. Темпус Тасиснинг «Тарих» лойихасини республикадаги энг муваффақиятли лойихалардан бири деб аташ мумкин.

1995 йилда яна 4 та Европа кўшма лойихаси иш бошладй. 1996 йилда 3 та дастлабки ва 3 та ихчам лойихалар ишга туширилди. Масалан. “Энергетика сохасидаги таълимни бошқариш" қўшма лойихаси республикада қабул қилинган энергиядан оқилона фойдаланиш тўғрисидаги қонунга мувофиқ келди ва унинг иши натижасида республикада биринчи марта 
энергетика сохасидаги менежерлар тайёрловчи магистратура очилди. Лойихани амалга ошириш жараёнида 12 кишидан иборат профессор-ўқитувчилар таркиби тайёрланди, магистрантларга ўқитиш учун ўқув кўлланмалари яратилди ва хоказо ${ }^{6}$.

Иккинчи давр 1997-1999 йиллар. Ушбу даврда республикада 9 та Темпус Тасис лойихаси амалга оширилди. 1997 йилда Ўзбекистонда учта Европа қўшма лойихаси ўз фаолиятини бошлади, шу жумладан ТДТУ(Тошкент Давлат Техника Университети)да “Энергия сохасида менежмент бўйича ўқув курсини ишлаб чиқиш” дастурнинг муваффақиятли лойихаларидан биридир. Уни амалга ошириш жараёнида «Энергия менежменти» ихтисослиги бўйича магистратура очилди, 3 та лаборатория ташкил этилди шунингдек 30 та фан буйича маьрузалар тайёрланиб, услубий кабинет, Интернетга уланган компьютер хонаси очилди. Лойиха якунида Европанинг иккита университети билан 5 йиллик шартнома имзоланди.

“Тўқимачилик саноати сохасида ўқув дастурларини модернизация қилиш” лойихаси натижасида ТТЕСИ (Тошкент тўқимачилик ва енгил Саноат институти)да минтақадаги ягона сертификатлаштириш маркази ташкил этилди. Ўкув дастурларини модернизация қилиш ва уларни Европа стандартларига яқинлаштириш учун ўқитувчилар учун амалиётлар ташкил этилди. Шу билан бирга ўқув жихозлари сотиб олинди ва маърузалар курслари тайёрланди. Темпус II ни амалга ошириш жараёнида республикада турли йўналишларда 12 та лойиха амалга оширилди. Фақатгина ТДТУ 3 та Европа қўшма лойихасини амалга оширди, улардан бири “Ўзбекистонда масофадан ўқитиш" масофадан туриб ўқитиш тизимини ривожлантириш бўлиб уларнинг тажрибаларини республиканинг бошқа университетлари ўртасида янада кенгроқ тарқатишга эътибор қаратилди. ““Халқаро муносабатлар ва хукуқ” мультидисиплинер магистрлик курсининг ташкил этилиши ЎзМУдаги «Евроосиё» лойихаси ишининг асосий натижаси бўлди?.

Шундай қилиб, Ўзбекистонда Темпус Тасис дастурининг амалга оширилишининг иккинчи даврида, республикада Европа иттифоқининг 7 та қўшма лойихаси амалга оширилди.

Темпус Тасис дастури Ўзбекистон ва Европа мамлакатларидаги олий ўқув юртлари билан яқин алоқаларни ўрнатишга хисса қўшди. Кўриб чиқилаётган даврда Ўзбекистон университетлари Европа Иттифоқи мамлакатларининг 65 университети билан хамкорлик алоқаларини ўрнатдилар.

Ўзбекистондаги Темпус лойихаларини қамраб олган тематик йўналишлар хам кенг бўлди: Амалга оширилган 8 та лойиха амалий фанлар ва технологиялар сохасини қамраб олди, 7 лойиха университет менежменти, ижтимоий фанларга оид 5 та лойиха, 3 та иқтисодга оид, иккита лойиханинг тематик йўналишлари Европа тилларини ўрганиш ва иккита лойиха гуманитар фанлар йўналишини қамраб олди. Битта лойиха қишлоқ хўжалиги ва озиқ-овқат саноатига, битта лойиха психология ва педагогикага бағишланган бўлиб мураббийларни тайёрлашга хам катта эьтибор берилди.

1994-1999 йилларда Ўзбекистондаги Темпус Тасис дастурининг умумий бюджети 6,071 миллион еврони ташкил этди.

Хаммаси бўлиб, 1994-1999 йиллар оралиғида. Республикадаги 17 та олий ўкув юртлари Темпус Тасис лойихаларининг Ўзбекистондаги фаолиятига жалб қилинган. Ўтган йиллар давомида умумий лойихалар сони 27 тани ташкил этди ва 3 та лойиха 2000 йилда бошланди.

2000-2006 йилларни қамраб олган Европа Иттифоқи Темпус дастурининг учинчи босқичи Ўзбекистондаги дастур фаолиятини ривожлантиришнинг энг қизғин ва самарали даври бўлди. Бу вақтга келиб республиканинг олий ўқув юртларида Темпус лойихасида иштирок этиш учун 6 йиллик тажриба тўпланган эди.

Барча иштирокчи мамлакатлар, шу жумладан, Ўзбекистон учун хам ушбу босқич бир қатор ўзгаришлар ва янгиликлар билан ажралиб турди, бу эса дастур фаолиятининг кенгайиши ва сифат жихатидан хилма-хил бўлишига ёрдам берди. Бу бир нечта шерик мамлакатлар учун кўшма лойихалар, нодавлат ташкилотларнинг лойиха консортсиумларида, таркибий ва қўшимча тадбирларда, индивидуал грантларда иштирок этиши ва таълим вазирликлари билан кенгайтирилган мулоқотида ўз аксини топди.

Танловларда иштирок этиш учун аризалар сонининг йилдан-йилга ўсиб бориши университетларнинг ушбу дастурга қизиқиши ортганлигини, лойихаларни ишлаб чиқиш ва бошқаришдаги иштироки фаоллашганини кўрсатди. Темпус дастурининг учинчи босқичини амалга ошириш давомида Ўзбекистонда 40 та лойиха бажарилди․

Республикада дастурнинг 1994-2006 йилларда юритган фаолияти даврда умумий бюджети

April|2021 
65 та лойихани амалга ошириш учун 17,4 миллион еврони ташкил этди, шу жумладан 20002006 йилларда унинг учинчи босқичида 11,2 миллион евро ажратилди ${ }^{10}$.

Темпуснинг Европа қўшма ўқув дастурларини ишлаб чиқиш лойихалари Кадрлар тайёрлаш миллий дастурини амалга ошириш билан, хусусан, икки поғонали олий таълим тизимини жорий этиш билан бевосита боғлиқлиги айниқса мухимдир.

Еттита университет бошқарув ходимларини тайёрлаш ва халқаро алоқаларни ривожлантириш орқали халқаро хамкорликни ривожлантирди. Тошкент ва Наманган шахарларида ишлаб чиқариш билан алоқа, Андижон ва Тошкент шахарларида тадбиркорлик фаолиятини қўллабқувватлаш бўлимлари ташкил этилиб, зарур жихозлар билан таъминланди.

Шу туфайли университетларда бир қатор янги тузилмалар яратилди: Тошкент аграр университети ва Ўзбекистон Миллий университетида таълим сифатини таъминлаш марказлари. Тошкент тиббиёт академияси қошидаги Амалий клиник кўникмаларни тайёрлаш маркази ва Тошкент транспорт институти хузуридаги Ахборот технологиялари маркази шулар жумласидандир.

Ўзбекистонда «МАТАДОР» ${ }^{1}$ Темпус лойихаси доирасида Тошкент давлат иқтисодиёт университети ўқитувчилари кичик ва ўрта бизнес тадбиркорлари учун менежмент сохасида қисқа муддатли амалий курсларни ишлаб чиқди. Тошкент ирригация институти Давлат табиатни мухофаза қилиш комитети бўлимлари ходимлари ва касб-хунар коллежлари ўқитувчилари

1 Матадор - институтциональ курилиш сохасида Ўзбекистондаги биринчи лойиха

Республикамизнинг турли минтақаларида жойлашган олий ўқув юртлари учун Темпус лойихаларида қатнашиш нафақат Европалик шериклар билан хамкорликни бошлашга, балки республиканинг бошқа университетлари билан хам алоқаларни ўрнатишга ёрдам берди. Масалан, Тошкент, Андижон ва Самарқанддаги тўртта қишлоқ хўжалиги университетлари қишлоқ хўжалиги иқтисодиёти, экология ва сув ресурсларини бошқариш бўйича лойихаларда хамкорлик қилдилар. Қарши, Урганч ва Нукусдаги учта университет биргаликда амалий экология буйича магистрлик дастурини ишлаб чикдилар.

2000 йилда қўшма Темпус лойихаси асосида Самарқанд ва Қаршида ташкил этилган иккита ресурс маркази ўқитувчилар ва талабаларни ўкув жараёнида ахборот технологияларидан фойдаланишга ўргатди.

Тенг ва ўзаро манфаатли шериклик дастури сифатида Темпус халқаро хамкорликни янада ривожлантириш йўлидаги биринчи қадамдир. Темпусни молиялаштириш тугагандан сўнг, республика университетлари ва Европа университетлари ўртасидаги хамкорлик ўқитувчилар ва талабаларнинг ўзаро алмашинуви, қўшма нашрларни ишлаб чиқиш, шунингдек, илмий ишларда конференцияларда қатнашиш ва бошқалар орқали сақланиб қолди.

TЕМПУС IVдастури 2007 йилда бошланган ва 2013 йилгача босқичма-босқич амалга оширилди. Дастурнинг 4-босқичини амалга ошириш давомида биргина Ўзбекистон Республикасида 14 та лойиха жорий қилинди.

2011 йилдан буён амалга оширилган Темпуснинг 4 та янги лойихасида 12 та университет (ТДТУ, АндҚХИ, НавДКИ, БухДУ, СамДУ, СамИСИ, ҚарДУ, ҚарМИИ) ва республиканинг 6 та вилояти шунингдек, Европа Иттифоқининг 17 университети ва 13 мамлакати қатнашди.

Кадрлар тайёрлаш миллий дастурини босқичма-босқич амалга ошириш, Ўзбекистон Республикасининг халқаро ташкилотларнинг олий таълим сохасидаги дастурлари ва фондлари, шу жумладан ТАСИС ТЕМПУС билан хамкорлиги ижобий натижалар берди.

Хусусан, олий ўқув юртларида 1500 дан ортиқ электрон дарсликлар, ўқув қўлланмалар тайёрланди, шунингдек, 44 та университетда кутубхоначиликни автоматлаштириш ва электрон каталогларни яратиш лойихаси амалга оширилди ${ }^{11}$.

2011-2016 йилларда олий ўқув юртларининг моддий-техник базасини модернизация қилиш ва мутахассислар тайёрлаш сифатини тубдан яхшилаш дастурига мувофиқ, олий таълим йўналишлари ва мутахассисликларининг янгиланган классификатори ишлаб чиқилди. Турдош мутахассисликларни бирлаштириш ва иқтисодиёт ва ижтимоий сохалардаги талаб қилинмаган мутахассисликларни қисқартириш хисобига бакалавриат учун таълим йўналишлари сони 228 тадан 165 тагача, магистрлар учун эса 1200 тадан 447 тагача камайди ${ }^{12}$.

Темпус лойихалари қуйидагиларга ўз хиссасини кўшди:

- магистратура ва бакалаврлар учун ўқув дастурларини ишлаб чиқиш, яъни умуман олий таълимнинг икки поғонали тизимини жорий қилишда;

- ўқув материалларини янгилаш ва ривожлантириш;

- олий ўқув юртлари бошқарувини қайта қуриш;

- ўқитувчилар ва маъмурларни янги билим ва кўникмалар билан малакасини ошириш;

- ташкилот ва жамият билан алоқаларни мустахкамлаш;

- барқарор илмий хамкорликни яратиш.

Темпус дастури Ўзбекистондаги бутун фаолияти давомида олий таълим тизимини ривожлантиришда мухим ёрдам кўрсатди ва шу билан мамлакатда таълим ислохотларини амалга оширишга кўмаклашди. 
учун атроф-мухитни бахолаш ва мониторинг қилиш бўйича тренинглар ўтказди.

Европа қўшма лойихаси хамда таркибий ва кўшимча тадбирлар доирасида бир қатор лойихалар республика университетларининг Европа Иттифоқи мамлакатларида Болония жараёнининг амалга оширилиши тўғрисида хабардорлигини оширишда ёрдам берди; Болония жараёни - бу Европанинг 70-йилларнинг ўрталарида бошланган ва Европа олий таълим сохасини яратиш мақсади билан таълим стандартлари тизимининг яқинлашиш жараёни бўлиб, 1999 йилда Европанинг 29 мамлакати вакиллари томонидан имзолангандан кейин Болония декларацияси қонуний равишда расмийлаштирилди.

Темпус дастури минтақавий хамкорликни ривожлантиришга катта хисса қўшди. Олмаота Технология Университети Тошкент кимё-технология институти ва Бухоро озиқ-овқат ва энгил саноат технологик институти билан хамкорликда озиқ-овқат хавфсизлиги сохасида янги ўқув дастурини яратиш лойихасида иштирок этди. Санкт-Петербург электротехника университети ва Уш давлат университети Андижон мухандислик-иқтисодий институти, Савдо-саноат палатаси, Андижон қишлоқ хўжалиги институти ва Тошкент молия институти билан хамкорликда тадбиркорликни қўллаб-қувватлашнинг тажрибавий моделини яратиш лойихаси муваффақиятли амалга оширилди.

\section{Фойдаланилган адабиётлар}

1. См.: Гармонично развитое поколение - основа прогресса. Узбекистан-Т.: Шарк,1997

2. См.: также Нуриддинов Э.З. Международное сотрудничество Узбекистана со странами Европы в условиях независимости: становление, развитие, проблемы // Автореф. дисс. докт. ист. наук. - Ташкент: ИИАН РУз, 2000. - С. 58.; Султанов А.В. История сотрудничества Узбекистана со странами Европы в гуманитарной сфере. 1991-2001 гг. // Автореф. дисс. канд. ист. наук. - Ташкент: Университет, 2006. - С. 30

3. Текущий архив Узбюро КЕС. Информационный пункт Темпус.

4. Отчет о ходе реализации Проекта ЕС (ТАСИС) ТЕМПУС СЕП «ТАРИХ». № - 122. 1997. - С. 5,12. См.также: Худайкулова Л.С. Интеграция Узбекистана в мировое сообщество на примере сотрудничества с европейским союзом. 1991-1999 гг. (Программа ТАСИС ТЕМПУС) // Автореферат дисс.канд.ист.наук. - Ташкент, Университет, 2002. - С. 28.

5. «Развитие отдела современного греческого языка», «развитие факультета пищевой технологии», «Пост-академическая степень по телематике», «Развитие степени магистра психологии». Пред СЕП - Предварительный (проект) совместный Европейский проект.

6. Финальный отчет о деятельности проекта P-SEP-03048-96. «Обучение менеджменту в сфере энергетики». 1999. - С. 5.

7. Этапный отчет проекта Темпус Тасис «ЕВРАЗИЯ». 1999. - С.5. 11.

8. Информационный бюллетень Темпус в Узбекистане. Уз Бюро КЕС. - Ташкент, 1999. - С.

9. http://Tempos.europahouse.uz/index/php? option=com contect\&view=category\&layout=blog8 \&ltemid=12\&lan

10. tempus III. In Uzbekistan... Tashkent, 2007. - p.26.

11.Буюк ва муқаддассан, мустақил Ватан: Ўзбекистоннинг 20 йиллик мустақил тараққиёт йўлида қўлга киритган ютуқ ва натижалари, мамлакатимизнинг салохияти ва ахамиятини ахолининг кенг қатламларига етказиш, жойларда ташкилий-амалий, маданий-маърифий тадбирлар, тарғибот ва ташвиқот ишларини амалга ошириш учун мўлжалланган / УзЗ олий ва ўрта махсус таълим вазирлиги, ЎзР махалла жамғармаси, масъул ижодий гурух. А.Ш.Бекмуродов (ва бошқ.). - Т.: “О‘qituvchi” НМИУ, 2011. - 159 б.

12. Правда Востока. 2011, 23 мая. 


\title{
MUQIMIY "SAYOHATNOMA"SIDA KELTIRILGAN QISHLOQLAR BILAN QISQACHA TANISHUV
}

\author{
Axmedova Mashhuraxon Ulug'bek qizi \\ Farg'ona davlat universiteti \\ Boshlang'ich ta'lim fakulteti 1-kurs talabasi
}

Annotatsiya. Ushbu tezis Farg'ona davlat universiteti 1-kurs talabasi tomonidan yozildan bo 'lib, unda Muqimiyning "Sayohatnoma" asarining g'oyasi qisqacha yoritilgan.

Muhammad Aminxo'ja Mirzaxo'ja o'g'li, taxallusi - Muqimiy. O‘zbek demokratik adabiyoti asoschilaridan biri. Otasi toshkentlik, onasi Oyshabibi xo'jandlik bo'lib, Qo'qonda yashaganlar. Muqimiy boshlang 'ich ma'lumotni mahallasidagi maktabda olgan. Onasi Muhammad Aminxo'jada she'riyatga xavas uyg'otgan. Muqimiy Qo'qondagi Nodira bino qilgan "Mohlaroyim" madrasasida, so'ng Buxoro madrasalaridan birida ta'lim olgan. 70- yillar oxirlarida Qo'qonga qaytgan va ijod bilan shug'ullangan. Otasi vafotidan so"ng moddiy ahvoli og'irlashgach, "Hazrat" madrasasining kichik bir hujrasiga ko'chib o'tgan, butun umri qashshoqlikda kechgan. ${ }^{[1]}$ Shunga qaramay ijod qilishdan to'xtamagan. U Qo'qonning mashhur xattotlaridan Muhammad Yusuf xattotdan ta'lim olib, xushxat kotib bo'lib yetishgan Muqimiyga xattotlik asosiy kasb va tirikchilik manbayi bo 'lib xizmat qiladi. ${ }^{[2]}$

$\mathrm{Bu}$ davrga kelib Muqimiy o'zining jo'shqin lirikasi va davrining hukmron ijtimoiy guruhlarini achchiq tanqid ostiga oluvchi hajviy asarlari, yumorlari bilan shuhrat qozonadi. ${ }^{[2]}$

Adabiyotimizda sayohatnoma janrining shakllanishi va takomilga erishuvida hassos shoir Muqimiyning xizmati katta. ${ }^{[2]}$

Endi "Sayohatnoma"ning tuzilishini ko"rib chiqsak.

"Sayohatnoma"ning ichki tuzilishi quyidagicha:

1. Kirish, ya'ni sayohatga chiqishdan ehtiyoji, sabablari aytiladi.

2. Yo'1 xotiralari batafsil bayon etiladi.

3. Sayohatdan muayyan xulosalar chiqariladi.

Muqimiyning murabba shaklida yozilgan "Sayohatnoma"si g'oyaviy-badiiy xususiyatlari bilan bu janrning orginal namunasi hisoblanadi. ${ }^{[1]}$

Bizgacha uning Qo'qondan - Isafaraga, Qo'qondan - Shohimardonga, Qo'qon- dan - Farg'onaga qilgan safaridagi taassurotlari yetib kelgan. Yozuvchi shahardagi biqiq sharoitdan chalg'ish, dam olish maqsadida qishloqlarga safarlar uyushtirgan, safar davomida o'zi tashrif buyurgan qishloqlarning o'sha davrdagi ahvoli haqida biz o'quvchilarga yozib qoldirgan. Biz asar bilan tanishuv safarini Qo'qondan - Shohimardonga bobidagi O’ltarma qishlog'i bilan boshlaymiz.

Mingboshilik kimning ishi,

Desam, dedi bedonishi

Bir "qo"shtegirmonlik" kishi

Xo'ja Iso badkor ekan.

To 'rtlik orqali bilib olamizki, o'sha davrlarda qishloq oqsoqollari sifatida xalqqa adolat qilmaydigan, "badkor" kimsalar tayinlangan. Bunday adolatsizliklarga befarq qarolmaganligi uchun ham Muqimiy mirzalik ishidan ham bo'shab olgan bo'lsa, ehtimol. Keying safarimiz Do'rmancha qishlog'i bo'lib, u yerni shoir qisqagina qilib "dashti qaroqchizor ekan" deya tasvirlaydi. U yerda ham bundan oldin ko'rganimiz, xalq norozilik kayfiyati bilan yashar edi.

Unda bo'lus G'ozi dedi,

Ham mufti, ham qozi dedi,

... Qilg'on ishi ozor ekan.

Albatta, yurt qozisining qiladigan ishi ozor bo'lgandan keyin xalqning farovon yashashini tasavvur etib bo'lmaydi. Oltiariq qishlog'ida ham holat O'ltarmadagidek, mingboshisi "bir dog'uli, ayyor ekan". Biz XIX asrlarda qishloqlarda siyosiy ahvolning yaxshi bo'lmaganligini shu misralar orqali ham bilib olishimiz mumkin.

"Oq yer" qishlog 'ida esa, holat qolganlaridan boshqacharoqligi aytib o'tilgan. Ya’ni u yerda “oliy 
imorat"larning borligi, aholining boy qatlam ekanligi ko 'rinib tursa, ham mehmon kelmasligi aytiladi, chunki "kelsa birov nochor ekan". Biz bundan butun aholining boy, lekin ziqna xalq ekanligini bilib olamiz.

"Roshidon" - Rishton qishlog'idan o'tib borar ekanmiz, uning firdavsmonand ekanligi, "O'ynab oqar obiravon, sahni gul-u gulzor ekan". U yerdagi "Suvlar sepilgan so "rilar" da hordiq chiqarib o "tirgan mahalda, "ta'bing mabodo choy tilar, damlashlari ishqor ekan" deyi Muqimiy... Vodil safarimiz davomidagi, eng maroqli, "dilkusho", "dilfuzo" maskan hisoblanadi. Shu bilan Shohimardon tomon qilgan safarimiz o'z nihoyasiga yetadi.

Endi Muqimiy bilan Qo'qondan Isfara tomonga yo'1 olar, manzaralar bilan tanishishda davom etar ekanmiz, u bizni "Yakkatut" qishlog 'iga olib kiradi. U yerdagi baqqolning noinsofligi Eshdavlat mingboshining qurumsoqligidan g'azablanadi. Undan o'tib Yayfanga kirganimizda esa, u yerdagi tolzorlar soyasida dam olgan insonda g'am yo' $q$ deydi. Rafqonga kirib esa omilarning ham o'zini mulla qilib ko'rsatishidan ranjigan Muhammad Aminxo'ja Rabot qishlog'iga yuzlanadi va o'zining qadrdonlarini izlab ular bilan ko'rishadi...

Qisqa qilib aytganda, biz Muqimiyning "Sayohatnoma" asari atrofidagi bo 'layotgan hodisalardan chalg 'ish, dam olish uchun qishloqlarga qilgan safaridagi taassurotlari jamlanmasi asosida vujudga kelganligining guvohi bo'ldik. Qishloq manzaralaridan XIX asrda aholining bilim saviyasining yuqori emasligi, qotib qolganligini bilib oldik, bunga yaqqol misol mingboshilarning tasviridir. Albatta, oddiy aholi o'rtasida ulardan ko'ra tadbirliroq shaxslar ham bo'lgan, lekin ularni himoyaga olib, davlatning rivojiga o'z xissalarini qo'shishlariga yo'l ochib berilmagan.

\section{Foydalanilgan adabiyotlar:}

1. $\mathrm{O}^{\prime} \mathrm{zME}$

2. 5- sinf adabiyot 


\title{
ВЫРАЗИТЕЛЬНОЕ ЧТЕНИЕ КАК ОСОБАЯ ФОРМА ФОРМИРОВАНИЯ КОММУНИКАТИВНОЙ КУЛЬТУРЫ
}

\author{
Доронина Ирина Николаевна \\ преподаватель кафедры русской филологии ФерГУ \\ Акборова Феруза Набиевна \\ студентка 3-курса ФерГУ
}

\begin{abstract}
Аннотация: В статье рассмотрены проблемы развития коммуникативных основ у обучающихся, использование различных форм деятельности педагога, способствующие развитию устного логически последовательного общения, определены лингвистические аспекты выразительности.
\end{abstract}

Ключевые слова: логика, общения, коммуникативные средства, коммуникативная форма;

Среди проблем профессии учителя-словесника одно из ведущих мест занимают общительные т.е коммуникативные проблемы, которые снижают качество педагогического труда, способствуют появлению барьера при установлении взаимопонимания, сотрудничества и диалога с обучающимися. Сегодня выпускники вузов с педагогической направленностью недостаточно владеют культурой общения, и они не всегда готовы к использованию в своей деятельности, на практике, коммуникативные средства воздействия на обучающихся, умело управлять психологическим состоянием личности, действовать в открытой публичной обстановке. Коммуникативная культура общения включает в себя не только технику речи, говорить правильно, укладываться вовремя изложить намеченный текст, но культуру самой личности, культуру мышления, культуру чувств. Формированию и совершенствованию коммуникативной культуры призваны занятия русской литературы и литературного чтения, где в основном происходит этот процесс и обучающиеся стремятся овладеть искусством художественного (выразительного) чтения, заключающегося в творческом воплощении литературного произведения, который действенно звучит в слове. [1]

Выразительность - особая структура речи, которая «поддерживает внимание и интерес слушателей», это «точность словесного обозначения предмета или явления, представления или понятия». «Говорить выразительно, красиво - значит выбирать слова образные, вызывающие деятельность воображения, внутренние видения и эмоциональную оценку изображенной картины, события, действующего лица». [2]

Вышеперечисленные определения позволяют сделать вывод о том, что ученые имеют в виду различные типы речевой выразительности. В зависимости от структурных областей языка бывает выразительность произносительная, лексическая, словообразовательная, морфологическая, синтаксическая и интонационная. Таков лингвистический аспект выразительности. Устная речь, в отличие от письменной речи - это живое общение. Для нее характерны: образность, эмоциональность, экспрессивность. Непосредственное общение с аудиторией накладывает отпечаток на синтаксис устной речи: говорящий часто использует различные типы простых предложений, особенно вопросительных и восклицательных, широко использует присоединительные и вставные конструкции, вводные слова, повторение одной и той же мысли, градацию доказательств и т.д. [1]

Выразительность устной речи усиливается интонацией, которая фактически оформляет речь, помогает активизации ее коммуникативной функции - функции общения между людьми. С. Волконский писал: «Голос - одежда, интонация - душа речи». [2] Интонация есть и в письменной речи, но речь и язык не могут быть сведены друг к другу. В языке оформляется далеко не все, что есть в речи. Конкретный смысл всякого высказывания вытекает, по мнению Н.Н. Жинкина, не только из содержания общения, но и из ситуации общения. [1] Интонация передает сведения не только о том, что говорится, но и о том, кто говорит, как, где и кому.

Возникает вопрос, к какой форме речи относится выразительное чтение. Мы убеждены, что к устной форме речи. Можно просто прочитать текст вслух, соблюдая знаки препинания, однако такое чтение не будет выразительным. Чтение выразительное - отличается от речи устной только тем, что оно не создается в процессе словесной импровизации, но в чтении так же, как и в устной речи, в единстве проявляются мысль, чувство и воля говорящего, поэтому, озвучивая текст, читающий выразительно не только вычитывает ту интонацию, которая вписана в него, 
но и выражает свое отношение к тому, о чем читает. Собственное отношение к читаемому, и обусловливает различные трактовки чтения. К.С.Станиславский говорил: «Смысл творчества - в подтексте. Без него слову нечего делать на сцене. В момент творчества слова - от поэта, подтекст - от артиста. Если бы было иначе, зритель не ломился бы в театр, а сидел бы дома и читал пьесу». [2] Главное, что кроется в выразительном чтении, было выдвинуто еще В.И. Чернышевым: «Читай так, как говоришь». Подтверждение этой мысли мы находим и у авторов современных работ: «Устная форма реализации литературного языка используется там, где необходимо живое звучащее слово: агитационно-пропагандистская деятельность (беседы, лекции, митинги), научная (доклады, диспуты), литературно-художественная (художественное чтение, сценическое представление)». [5]

Работа над выразительным чтением основывается на искренности переживаний. Чтобы говорить «с чувством», чтец должен стремиться к словесному действию. Нередко обучающиеся механически проговаривают слова. Но нужно, чтобы говорящий (читающий) осмысленно и целеустремленно общался со слушателями. Для этого он должен хорошо знать, что именно (тема) и с какой целью (идея) он хочет донести текст до слушателей. Постановка конкретной задачи и позволяет повысить действенность речи и чтения. К. С. Станиславский отмечал: «Говорить - значит действовать. Эту-то активность дает нам задача: внедрять в других свои видения. Неважно - увидит другой или нет. Об этом позаботится матушка-природа и батюшкаподсознание». [2] Искусство художественного чтения - самостоятельный вид искусства. Его определяют как «вторичную относительно самостоятельную художественную деятельность, творческая сторона которой проявляется в форме художественной интерпретации». При этомпод художественной интерпретацией понимается «трактовка продукта первичной художественной деятельности в творческом процессе исполнения». Действительно, музыкальное искусство не может обойтись без композитора, и композитор нуждается в инструменталистах и певцах. То же самое справедливо по отношению к драматургу и актеру. В связи с тем, что искусство чтения приобрело свою самостоятельность в результате длительного процесса трансформации устного народного творчества в письменную литературу, авторский стиль многих произведений порой никаким другим искусством, кроме искусства чтения, выраженным быть просто не может. [3]

Таким образом, художественно - выразительное чтение это искусство синтетическое, оно лежит на стыке литературы и сценического искусства. Однако в каждом из этих искусств воплощение произведения осуществляется разными выразительными средствами. В театре пьеса разыгрывается коллективом актеров, в искусстве чтения исполнителем является один человек и он как мастер выразительного чтения передает слушателю произведение, созданное авторами художественного слова.

\section{Литература:}

1. Богданова О.Ю. «Методика выразительного чтения: проблемы, перспективы »; Москва, 1986 год

2. Лотман Ю.М. «О поэтах и поэзии»; Искусство, 1996 год;

3. Коровин В.И. «Русская поэзия 19 века»; Москва, 1983 год;

4. Руденко-Десняк А. Выбор и путь // Дружба народов, 1982,. № 5. 


\title{
DIAGNOSTIC EFFICIENCY OF ELASTOGRAPHY IN PATIENTS WITH PAROTID GLAND TUMORS
}

\author{
Iriskulova Elmira Uraimkulovna \\ Tashkent State Dental Institute, \\ Department of Maxillofacial Surgery
}

\begin{abstract}
Parotid tumor is the most common type of major salivary gland tumors. Diagnostic of neoplasm of parotid salivary glands presents significant difficulties and is an actual problem. The aim of the study was to evaluate the diagnostic efficiency of sonographic elastography in the diagnosis of parotid tumors. In this study twenty-seven patients were examined by ultrasound elastography. The findings of elastography were compared with the histopathological examination results after surgical operation. Differences in patients with benign and malignant parotid gland tumors were indicated as statistically significant. Benign parotid tumors had 2,3, 4 elasticity scores and strain-ratio (SR) was 3,59 $\pm 0,10$. Malignant parotid tumors were presented by 4 and 5 elasticity scores, $\mathrm{SR}=5,66 \pm 0,73$.
\end{abstract}

Keywords: elastography, malignant tumor, pleomorphic adenoma, salivary glands, Warthin tumor.

Most parotid tumors are benign, pleomorphic adenoma and Warthin tumors are common parotid tumors. [1]. Pleomorphic adenoma accounts for an overall rate in Europe of 4.2-4.9 per 100,000 person-years [2]. Elastography - is the method of beam diagnosis of normal and pathological tissues stiffness by measuring the degree of strain on the tissue. Elastography is widely used in the diagnosis of breast, uterus, liver, thyroid cancer, and metastatic lesions of the neck lymph nodes [3].

Objectives. Our aim was to determine the diagnostic efficiency of elastography of tumors of parotid salivary gland.

Material and methods. The study included 20 patients $(74.1 \%)$ with benign tumors of parotid salivary gland and 7 patients $(25.9 \%)$ with malignant tumors. At $16(59,3 \%)$ patients diagnosed pleomorphic adenoma, $4(14,8 \%)$ patients - Warthin tumor, adenoid cystic carcinoma - 1 patient $(3,7 \%)$, adenocarcinoma -2 patients $(7,4 \%)$, metastatic tumors -3 patients $(11,1 \%)$, undifferentiated carcinoma -1 patient $(3,7 \%)$.

Strain elastography was performed using ultrasonography scanner LOGIQ S8 equipped with a linear transducer of $7-10 \mathrm{MHz}$ by applying external compression. On the elastogram images, numerical strain values of parotid tumor and surrounding soft tissue were measured using Strain-ratio (SR). All elastograms were scored with a scoring system (E.Ueno, 2006).

In all studied patients, postoperative histopathological results were compared with elastography findings. $\mathrm{p}$-Value of less than 0,05 was considered to indicate statistically significant difference in patients with parotid tumors. All statistical analyses were performed using Statistica (version 10) software package.

Results. Differences of elastography at benign and malignant tumors of the parotid gland were statistically significant $(\mathrm{p}<0,05)$. Benign tumors of the parotid glands represented by $2,3,4$ elasticity score. SR was 3,59 $\pm 0,10$. Malignant tumors were characterized by the presence of tissue stiffness at strain elastography, with the presence of 4 and 5 elasticity scores, $\mathrm{SR}=5,66 \pm 0,73$.

Conclusions. Elastography is helpful for the diagnosis of tumors in the parotid salivary glands. This method showed diagnostic efficiency in the differential diagnosis of benign and malignant tumors of the parotid glands. For this reason, physicians should use in diagnostic process the strain elastography.

\section{List of references:}

1. Zhan, Kevin Y., et al. "Benign parotid tumors." Otolaryngol Clin North Am 49.2 (2016): 327-342.

2. Valstar, M. H., et al. "Salivary gland pleomorphic adenoma in the Netherlands: A nationwide observational study of primary tumor incidence, malignant transformation, recurrence, and risk factors for recurrence." Oral oncology 66 (2017): 93-99.

3. Pehlivan, Müberra, et al. "Diagnostic role of ultrasound elastography on lymph node metastases in patients with head and neck cancer." Brazilian journal of otorhinolaryngology 85.3 (2019): 297302. 


\section{PSORIATIK ARTRITDA ALKOGOLSIZ YOGLI JIGAR KASALLIGINING ROLI VA DAVOLASHNI TAKOMILLASHTIRISH USULLARI.}

Muhsimova N.R. Toshkent tibbiyot akademiyasi

$\mathrm{O}^{`}$ zbekiston, Toshkent

Izlanish maqsadi: Alkogolsiz yog'li jigar kasalligining psoriatik artritdagi rolini o'rganish va davolashni takomillashtirish.

Psoriatik artrit - autoimmun xarakterga ega bo'lib, asosan teri, keyinchalik bo'gimlar va ichki a'zolar zararlanishi bilan kechadigan surunkali yallig'lanish kasalligi. Psoriatik artritda metabolik sindrom rivojlanish xavfi yuqori turadi. Metabolik sindromda gepatobiliar sistemada eng ko' $p$ kuzatiladigan kasalliklardan biri alkogolsiz yog'li jigar kasalligi hisoblanadi.

Tekshiruv usullari. 70ta bemor organildi. 11 ta erkak va 59ta ayol,bemorlar yoshi 18 yoshdan 75 yoshgacha(ortacha yosh 52,5+0,9) tashkil qiladi. Kasallik davomiyligi 6 oydan 26 yilgacha. Erta psoriaz bilan kasallangan bemorlar psoriatik artrit bilan kasallangan bemorlar bilan taqqoslandi. Klinikaga birinchi tashrif buyurgan bemorda tana vaznining indeksini (TVI) birlamchi tahlil qilingan. Kasallik aktivligini pasaytirish maqsadida barcha bemorlarga diyeta, davolovchi jismoniy tarbiya bilan birgalikda psoriatik artritning bazis davosi, gepatoprotektorlar va ursodezoksxol kislotasi buyurildi.O'tkazilgan davo samarasini nazorat qilish va kasallikning faollik korsatkichini davolash maqsadida har oyda bemorlar qayta ko'rigi tashkil qilindi.

Tekshirishlar natijasi shuni ko'rsatadiki psoriatik artrit bilan kasallangan bemorlarda yog'li gepatoz uchrash xavfi yuqori turadi.

O'tkazilgan bazis davolash fonida bemorlarning ahvoli yahshilandi, bo'g'imlarda og'riq kamaydi, bog'imlar harakati yahshilandi, jigardagi bioximik ko'rsatkichlar AlT va AsT normaga keldi, lipid spektri kamaydi. 1-guruh: Psoriatik artrit jigar jarohatlanishisiz bemorlarda ko "rsatkichlar 90\% bemorlarda "a'lo", 10\% bemorlarda "yaxshi" natija berdi. 2-guruh: Psoriatik artrit jigar jarohatlanishi bilan bemorlarda ko "rsatkichlar 67\% "a'lo", 24\% "yaxshi" va 9\% "qoniqarli" natija berdi.

Xulosa. Kuzatuv va tahlillarga asoslanib psoriatik artrit alkogolsiz yog "li jigar kasalligi bilan kechganda bazis davo, ursodezoksixol kislotasi va gepatoprotektorlar effektivligi yuqori baholandi. Shuningdek jigar fibrozi darajasida asoratlanishi oldi olindi hamda psoriaz va psoriatik artritning faollik darajasini kamayishiga erishildi. 


\title{
ПРОФИЛАКТИКА И ЛЕЧЕНИЕ КОРОНОВИРУСНОЙ ИНФЕКЦИИ СОVID-19 В АМБУЛАТОРНЫХ УСЛОВИЯХ С ИСПОЛЬЗОВАНИЕМ ИНФРАКРАСНОЙ РЕЗОНАНСНОЙ ТЕРАПИИ
}

\author{
А.С. Алимов, Р.Х. Рахимов, У.С. Алимов \\ Центр развития профессиональной квалификации \\ медицинских работников при Минздраве РУз \\ НПО «Физика-Солнце», институт материаловедения \\ Академии Наук Республики Узбекистан
}

\begin{abstract}
: 20 people were examined, 10 of them suffered from mild case of coronavirus infection (Covid-19) and 10 who were in contact with patients with Covid-19. In addition to traditional therapy, all patients underwent infrared resonance therapy (IRT), using a common unit that regenerates infrared pulsed radiation of the RC type, ZB, GI and KL (RC - antiviral, ZB - improves microcirculation in vessels, GI - antimicrobial and KL - immunostimulating) For all emitters and IRT method there is an FDA certificate [510 (k) Premarket Notification for TLC infrared Lamps. KO 33035. Nov 20 2003]. Studies have shown that traditional therapy, in combination with infrared resonance therapy, improves the quality and shortens the duration of the treatment for Covid-19 corona virus infection in patients with asymptomatic and mild disease.
\end{abstract}

Key words: coronavirus infection, prevention, treatment, infrared resonance therapy.

Актуальность. В течение 12 месяцев весь мир погружен в короновирусную пандемию. И каждый раз каронавирусная инфекция удивляет медицинских работников своими новыми мутациями, способностями поражать различные органы и системы организма, что делает её более опасной для человечества.

К сожалению, на сегодняшний день средства специфического лечения и профилактики SARS CoV-2 (Covid-19) не достаточно разработаны.

Неспецифическая профилактика коронавирусной инфекции направлена на мероприятия по предупреждению завоза и распространения Covid-19 на территорию Республики, регламентированная Постановлением Кабинета Министров Республики Узбекистан от 23 марта 2020 года за №176 «О дополнительных мерах по предотвращению распространения коронавирусной инфекции», Постановлением Президента Республики Узбекистан №ПП4649 от 26 марта 2020 года «О дополнительных мерах по предупреждению широкого распространения коронавирусной инфекции в Республике Узбекистан», Постановлением Президента Республики Узбекистан № ПП- 4652 от 26 марта 2020 года «О дополнительных мерах по поддержке медицинских работников и работников санитарно-эпидемиологической службы, привлеченных к противодействию распространению коронавирусной инфекции».

Несмотря на определенные достижения в медикаментозной терапии больных с Covid-19, растет число временной нетрудоспособности больных в течение нескольких месяцев, а также осложнения, связанные с тромбоэмболиями сосудов сердца и головного мозга, приводящие к инвалидности на всю жизнь.

В связи с этим, совершенствование методов профилактики, лечения и реабилитации больных с Covid-19, остаётся актуальной проблемой медицины.

Цель работы. Совершенствование методов лечения легкой формы течения коронавирусной инфекции Covid-19 и её профилактики с использованием инфракрасной резонансной терапии по методу Рахимова Р.Х. (2000) в амбулаторных условиях.

Материал и методы. Под нашим наблюдением находились 20 человек. Из них 10 пациентов инфицированных Covid-19, с легкой степенью тяжести течения, в возрасте от 30 до 50 лет, находившиеся на лечении в домашних условиях и 10 человек того же возраста, бывшие в контакте с ними.

Диагностика Covid-19, проводилась врачами поликлиник, согласно рекомендаций ВО3 и протоколу, представленного Минздравом Республики Узбекистан.

Всем пациентам наряду с традиционной терапией, дополнительно проводили инфракрасную резонансную терапию (ИРТ), при помощи общей установки, генерирующей инфракрасные импульсные излучения типа $\mathrm{RC}$,

ZB, GI и KL. (RC- противовирусная, ZB - улучающая микроциркуляцию в сосудах, GI - 
противомикробная и $\mathrm{KL}$ - иммуностимулирующая) На все излучатели и на ИРТ метод имеется сертификат FDA [510 (k) Premarket Notification for TLC infrared Lamps. KO 33035. Nov 202003 ].

Принцип действия инфракрасного излучения на организм человека заключается в том, что фермент Ревертаза, ответственный за обратную транскрипцию РНК вируса с ДНК человека, представляет из себя радикал.

Импульсы, генерируемые излучателями RC, RV создают короткоживущие радикалы из воды, заставляющие фермент-субстратный комплекс связываться с ним и происходит реакция рекомбинации, вследствие которого фермент превращается в завершенную молекулу и препятствует осуществлению других реакций.

Предлагаемая методика ИРТ заключается в следующем: для профилактики коронавирусной инфекции, экспозиция инфракрасных излучателей проводится в течение 15 минут, один раз в неделю, а для лечения коронавирусной инфекции бессимптомной и легкой степени течения, экспозиция излучателей, также по 15 минут 2 раза в день в течение 3-5 дней, до полного исчезновения симптомов заболевания и получение отрицательного ответа на наличие коронавирусной инфекции.

В последующем для профилактики вирусной инфекции и патогенной микрофлоры, а также для улучшения микроциркуляции в сосудах и восстановления иммунитета организма, экспозиция инфракрасных излучателей должна проводиться один раз в неделю в течение 15 минут.

Это связано с тем, что инкубационный период проявления коронавирусной инфекции составляет 7-14 дней, что является достаточным для нахождения под воздействием импульсов, генерируемых излучателями RC, ZB GI и KL в течение указанного времени.

Результаты. Обследованные пациенты, с легкой степенью течения Covid-19, жаловались на повышение температуры тела до 37,3 - 37,6 градусов, сухой кашель, на нарушение вкуса, потливость и общую слабость.

Врачами семейной поликлиники им были назначены препараты витамина $\mathrm{D}$, витамина $\mathrm{C}$, цинка, Лактофильтрум, обильное питьё до 3-4 литров в сутки, а при повышении температуры тела Парацетамол или Нимесил.

Несмотря на проводимую традиционную терапию, у 4 пациентов на 7 сутки заболевания, периодически повышалась температура тела до 37,2 -37,5 градусов, они жаловались на кашель и общую слабость. Диагностика дыхательной системы (пульсоксиметрия) показала сатурацию (SpO2) 92-93\%.

После назначения ИРТ - терапии, после 2-3 сеансов, температура тела нормализовалась, прекратился кашель, намного уменьшилась слабость, а также улучшилось самочувствие. Сатурация (SpO2) повысилась до 95-97\%.

Проведенные тесты (ПЦР) на наличие коронавирусной инфекции у всех пациентов с легкой степенью течения Covid-19, показали отрицательный результат. После проведенного лечения, больные с легким течением Covid-19, никаких жалоб не предъявяли.

У 2 пациентов с Covid-19, имелись сопутствующие заболевания, как сахарный диабет 2 типа, средней степени тяжести (сахар крови- 8,5 ммоль/л) и гипертоническая болезнь II стадии (АД 160/100 мм рт.ст.).

После 2- го сеанса ИРТ - терапии, сахар крови снизился до 6,0-6,5 ммоль/л, артериальное давление снизилось до 130/80 мм рт. ст.

У 3-х человек, контактировавших с больными Covid-19, на 7 сутки появились кашель, повысилась температура тела до 37,1-37,3 градусов, а также потливость и легкая слабость. После 3-4 сеансов ИРТ - терапии, все симптомы заболевания исчезли.

У остальных 7 человек, контактировавших с больными Covid-19, в профилактических целях была проведена ИРТ - терапия с экспозицией инфракрасных излучателей, в течение 1520 минут, один раз в 5-6 дней. Всего было проведено 3-4 сеанса. Проведенные тесты (ПЦР) на наличие Covid-19, дали отрицательный результат.

Таким образом, следует отметить, что традиционная терапия в совокупности с ИРТ терапией, может быть эффективно использована в профилактике и лечении коронавирусной инфекции Covid-19 у больных с бессимптомной и легкой формой течения заболевания. 


\section{Список использованной литературы}

1. Алимов А.С., Рахимов Р.Х. Резонансная терапия (узкоспектральное инфракрасное излучение) в комплексном лечении болезней пародонта. Методические рекомендации. Ташкент, 2007. 15 с.

2. A. Alimov, R. Rakhimov, U. Alimov, A. Azizov. Treatment Of Patients With Asymptomatic And Mild Case Of Covid-19 Infection And Its Prevention In Outpatient Basis By Using Infrared Resonance Therapy. European Journal of Molecular \& Clinical Medicine. ISSN 2515-8260 Volume 07, Issue 03, 2020. p. 5356-5358.

3. Rahimov R.Kh. «Sinthezis of functional ceramice on BSP and developments based on it», Comp. nanotechnol. 2015. № 3. 11-15.

4. Rahimov R.Kh., Tikhonova N.N. "Resonance therapy. Ceramic materials and methods of their application in medicine". Comp. nanotechnology, 2017. 1. 75-134.

5. Hubert J., Rakhimov R.Kh., Peter J., Yermakov V.P. "Endangered health - opportunity with efficient innovations", Comp. nanotechnology, 2020. 1. 11-14.

6. Guan W.J., Ni Z.Y., Hu Y. et al. Clinical characteristics of coronavirus disease 2019 in China. N Engl J Med. 2020. [Электронный ресурс]. Режим доступа: https://www.ncbi.nlm.nih.gov/ pubmed/32109013/ (дата обращения: 22.10.2020).

7. Huang C., Wang Y., Li X. et al. Clinical features of patients infected with 2019 novel coronavirus in Wuhan, China. Lancet. 2020;395(10223):497-506. [Электронный ресурс]. Режим доступа: https://www.ncbi.nlm.nih.gov/pubmed/31986264/ (дата обращения: 22.10.2020).

8. COVID-19 Treatment Guidelines Panel. Coronavirus Disease 2019 (COVID-19) Treatment Guidelines. National Institutes of Health. [Электронный ресурс]. Режим доступа: https://www. covid19treatmentguidelines.nih.gov/ (дата обращения: 08.2020). 


\section{ЧАСТОТА ВСТРЕЧАЕМОСТИ ПАРАЗИТОЗОВ СРЕДИ ДЕТЕЙ С БРОНХИАЛЬНОЙ АСТМОЙ}

Касимова М.Б.

Ташкентский государственный стоматологический институт, Узбекистан

Рост распространенности аллергических заболеваний (АЗ) является серьезной медико-социальной проблемой во всех странах мира $[5,9,10]$. Распространенность гельминтно-протозойных инфекций также достаточно высока: в настоящее время в мире зарегистрировано около 500 видов гельминтов, паразитирующих у человека $[1,10]$.

Цель работы. Определить частоту встречаемости паразитозов среди наблюдаемых детей с бронхиальной астмой.

Результаты исследования. В исследовании приняли участие 100 детей в возрасте от 2 до 16 лет включительно: - Основная группа: дети с БА ( $\mathrm{n}=70$, средний возраст $6,14 \pm 0,13$ лет); - Контрольная группа: дети без аллергических заболеваний $(\mathrm{n}=30$, средний возраст $6,41 \pm 0,21$ лет). По данным ряда исследований, существует взаимосвязь риска возникновения паразитарных заболеваний с полом и возрастом ребенка, а также зависимость от условий проживания. Среди пациентов основной группы городских жителей было больше (51 ребенок, 55,9 \%), чем сельского населения (19 пациент, 44,1\%). Такая же тенденция наблюдалась и у детей контрольной группы - 20 (67\%) и 10 (33\%) соответственно (p=0,52). Так, среди исследуемых нами детей наибольшую долю составили мальчики: 49 в основной и 21в контрольной группе $(\mathrm{p}=0,121)$. При сравнении пациентов в исследуемых выборках по возрастному признаку также не было выявлено статистически значимых различий. Наличие сопутствующих аллергических заболеваний выявлено у 61 больных, что составило 67,0\%. Среди коморбидной патологии наиболее часто регистрировался аллергический ринит - 53 пациента $(19,6 \%)$, реже атопический дерматит - 17 (11,4\%). Согласно результатам паразитологического обследования, среди исследуемых нами детей с аллергическими заболеваниями паразитарная инвазия была выявлена у 66 человек, что составило 36,2\%. Среди пациентов контрольной группы гельминтозы и лямблиоз были диагностированы лишь у 4 детей $(13,3 \%),(p=0,000001)$. Таким образом, результаты проведенного исследования показали, что частота встречаемости паразитозов в выборках детей, сопоставимых по полу, возрасту и условиям проживания, в 2,7 раз выше среди больных с БА, по сравнению с детьми без аллергопатологии. Наиболее частыми клиническими признаками паразитов были: аллергический синдром $(75,6 \%)$; диспепсический $(44,7 \%)$ и абдоминальный болевой синдром (35,6\%); астеноневротический синдром $(21,4 \%)$; синдромы поражения органов ЖКТ и гепатобилиарной системы: реактивные изменения печени и поджелудочной железы $(38,9 \%)$, дискинезия желчевыводящих путей $(30,7 \%)$, диспротеинемия (6,2\%), анемический синдром (18,0\%), синдром дефицита массы тела (18,5\%), эозинофилия крови (59,9\%). В структуре паразитарных инвазий у детей с БА $(\mathrm{n}=70)$ наиболее часто регистрировался лямблиоз - 54\% (43 пациента), реже аскаридоз - 38\% (17 человека), описторхоз - 6,1\% (6 детей) и токсокароз 1,0\% (4 ребенок). Причем у 9 больных $(7,1 \%)$ была выявлена сочетанная паразитарная инвазия.

Выводы. Таким образом, можно предположить, что в патогенезе хронических аллергических заболеваний, таких как бронхиальная астма ключевую роль играет инвазия лямблиями.

\section{Список литературы}

1. Degarege, A. Association between intestinal helminth infections and underweight among school children in Tikur Wuha Elementary School, Northwestern Ethiopia / A. Degarege, B. Erko //J. Infect. Public Health. - 2013. - Vol.6, № 2. - P. 125-33.

2. Mirrakhimova M. X. et al /Antileukotriene Drugs in The Treatment of Atopic Dermatitis in Children. International Journal of Pharmaceutical Research |Jan - Mar 2021|Vol 13 | Issue 1: 21172121 
3. Nishonboyeva N. Yu. et al. Digestive organs status in children with atopic dermatitis /Journal of Critical Reviews, 2020.7/5. 678-679

4. S.A. Ibragimova et al /Comordid course of atopic dermatitis with bronchial asthma in children: frequency, clinical and allergological characteristics - Journal of Critical Reviews, 2020.7/17. 2317-2321

5. WAO White book on Allergy. - 2011-2012. - P. 13

6. Zakirova U.I. et al /Analysis of The Prevalence of Bronchial Asthma in Children in Outpatient Clinics. International Journal of Pharmaceutical Research | Oct - Dec 2020 | Vol 12 | Issue 4: 759-765. 


\section{ВЫЯВЛЕНИЕ ПОЛИМОРФИЗМА ГЕНА IL10 G-1082A (RS3024491) У БОЛЬНЫХ С ЯЗВЕННОЙ БОЛЕЗНЬЮ В УЗБЕКСКОЙ ПОПУЛЯЦИИ}

М.У. Турсунова

Ассистент кафедры пропедевтики внутренних болезней №1 Ташкентской медицинской академии, Ташкент, Узбекистан.

К.Т. Бобоев

д.м.н.профессор, заведующий отделом молекулярной генетики и клеточных технологий Республиканского специализированного научно-практического медицинского центра гематологии

Д.С. Маткаримова

д.м.н., доцент кафедры гематологии, трансфузиологии и лабораторного дела Ташкентской медицинской академии, Ташкент, Узбекистан.

Резюме: В данном исследовании мы оценили степень участия полиморфизма rs3024491 гена IL-10 в развитии ЯБЖ и ЯБДПК. Анализ результатов показал, что как в основной группе больных, так и подгруппах пациентов с ЯБЖ и ЯБДПК частота встречаемости аллельных и генотипических вариантов полиморфизма rs3024491 гена IL10 (G-1082A) характеризуется отсутствием значимых статистических различий по сравнению с таковыми в контрольной группе, что свидетельствует об отсутствии его ассоциации с развитием ЯБЖ и ЯБДПК.

Ключевые слова: IL10 (G-1082A), ЯБЖ, ЯБДПК.

Summary: In this study, we assessed the degree of participation of the rs3024491 polymorphism of the IL-10 gene in the development of gastric ulcer and duodenal ulcer. Analysis of the results showed that both in the main group of patients and in subgroups of patients with GU and DU, the frequency of occurrence of allelic and genotypic variants of the rs3024491 polymorphism of the IL10 gene (G-1082A) is characterized by the absence of significant statistical differences in comparison with those in the control group, which indicates the absence of its association with the development of GU and DU.

Key words: IL10 (G-1082A), GU, DU.

Цель исследования. Оценка значимости гена регулятора воспаления IL10 (rs3024491) в предрасположенности к развитию язвенной болезни желудка и двенадцатиперстной кишки.

Материал и методы. В исследование включено 100 взрослых (основная группа, медиана возраста- 48,8 3,8 лет) неродственных пациентов узбекской национальности с установленным диагнозом язвенная болезнь желудка и двенадцатиперстной кишки согласно современным классификационным критериям (2010), находившихся на стационарном лечении в клиниках Ташкентской медицинской академии в период с 2019 по 2020 гг.

Результаты и обсуждение. Распределение частот генотипов rs3024491 гена IL10 и их соответствие популяционному равновесию Харди-Вайнберга (PХВ) проводилось раздельно в основной группе и группе контроля.

Показано, что наблюдаемое в исследованных группах распределение частот генотипов соответствовало ожидаемому по РХВ, о чем свидетельствовало значение $\mathrm{p}>0,05$. Полученные результаты указывают на однородность исследованной выборки. Результаты тестов хорошо коррелируют между собой, что с учетом объема выборки позволяет говорить о действительном отсутствии отклонений от РХВ.

Сравнительная оценка различий в доле встречаемости аллелей и генотипов полиморфизма rs3024491 гена IL10 позволила установить отсутствие статистически значимых различий между контрольной группой и основной группой пациентов с ЯБ.

Оценка различий в распределения частот аллелей и генотипов полиморфизма rs3024491 гена IL10 по сравнению с контрольной группой в Ia - и Ib - подгруппах пациентов с ЯБ также показала отсутствие статистически различий по сравнению с долей частот аллелей и генотипов в контрольной группе. Кроме того, мы провели оценку различий в распределении доли частот аллелей и генотипов между Ia - и Ib - подгруппами больных.

Таким образом, изучение особенностей распределения частот аллельных и генотипических 
вариантов полиморфизма rs3024491 гена IL10 показало отсутствие их ассоциации с развитием ЯБЖ и ЯБДПК.

Данные факты можно объяснить тем, возможно особенностями этнической принадлежности пациентов, а также, помимо этого, необходимо учитывать тот факт, что факторы, принимающие участие в сложных системных процессах, работают во взаимодействии, обеспечивая инициирование, потенцирование или ингибирование функции отдельных систем, а также функциональную компенсацию одного звена другим, направляя при этом биологический процесс по альтернативному физиологическому пути. В этой связи, изменение одного гена, кодирующего тот или иной процесс, может не оказать влияния на всю систему в целом, однако, изменение двух и более генов может кардинально изменить системный процесс и обусловить развитие патологии. Поэтому, при исследовании ассоциации генетических полиморфизмов с развитием заболевания целесообразно оценивать влияние не одного, а нескольких генов.

Заключение. Известно, что в патогенезе воспаления и формирования язвенной болезни значительная роль отводятся генам регуляторам иммунного ответа, в связи с чем, проводится активное изучение участия ключевых генов цитокинов в механизмах развития заболевания. На сегодняшний день накоплено достаточно достоверных данных о вовлеченности различных генов цитокинов, продукты которых принимают непосредственное участие в процессах регуляции иммунного ответа при воспалительных процессах ЖКТ. Однако, среди этих работ исследования, посвященные генетическим механизмам формирования язвенной болезни желудка и двенадцатиперстной кишки (ЯБДПК), носят весьма противоречивый характер. 


\title{
РОЛЬ И ЗНАЧЕНИЕ ДИАГНОСТИКА ЛОКАЛЬНЫХ ФОРМ РАКА ПРЕДСТАТЕЛЬНОЙ ЖЕЛЕЗЫ С ИСПОЛЬЗОВАНИЕМ СОВРЕМЕННЫХ ТЕХНОЛОГИЙ ТРАНСРЕКТАЛЬНОГО УЛЬТРАЗВУКОВОГО ИССЛЕДОВАНИЯ
}

\author{
Мамадалиева Яшнар Салиевна', \\ Хушназаров Хасан Холикович ${ }^{2}$, \\ Абдукодирова Махфуза Ботировна ${ }^{3}$. \\ Учреждение: \\ 1Зав. курсом кафедры «Онкология с курсом \\ ультразвуковой диагностики», ЦПРМР, г.Ташкент, Республика Узбекистан \\ ${ }^{2}$ Ассистент кафедры «Онкология с курсом ультразвуковой \\ диагностики», ЦПРМР, г.Ташкент, Республика Узбекистан \\ ${ }^{3}$ Врач ультразвуковой диагностики частной клиники \\ «МЕДФАЙТЕМ» г.Ташкент, Республика Узбекистан \\ e-mail aвтора: xasan1982.uzd@mail.ru
}

Ключевые слова: узловые заболевания предстательной железы, трансректальное ультразвуковое исследование

Актуальность. Проблема рака предстательной железы (РПЖ) приобрела на сегодняшний день особую актуальность вследствие неуклонного роста заболеваемости и смертности, а также в связи с трудностями своевременной диагностики. Новые возможности в ультразвуковой диагностике РПЖ открывает ультразвуковой эластография - неинвазивная методика, дающая возможность оценивать жесткость (эластичность) мягких тканей.

Цель исследования: Определение возможностей ранней диагностики рака предстательной железы, на основании данных ТРУЗИ.

Материалы и методы. Проведен ретроспективный анализ 100 больных раком предстательной железы, подвергшихся трансректальному ультразвуковому исследованию с 2016 по 2019 г. Из верифицированного гистологически рака предстательной железы 15 (15\%) пациента имели ложноотрицательные результаты ТРУЗИ, то есть при исследовании отсутствовало очаговое поражение зон железы. Произведен анализ 15 заключений трансректального ультразвука с ложноотрицательными данными в отношении рака предстательной железы. Возраст пациентов $63 \pm 7$ лет. Уровень ПСА в обследуемой группе от 1,01 до 64,2 нг/мл. По данным гистологического заключения, у 9 (60\%) пациентов выявлен рак простаты в стадии Т1-Т2с, у 6 (40\%) - в стадии Т3-Т4. При этом патологические изменения распределились по зонам железы в следующей локализации: у $10(66,7 \%)$ пациентов - периферическая зона железы, у 3 (20\%) центральная зона, у 2 (13,3\%) - транзиторные зоны. Ультразвуковые исследования проводились на современных ультразвуковых аппаратах «MINDRAY ДС-70» (Китай) и «MINDRAY ДС-80» (Китай) с использованием внутриполостного микроконвексного датчика с частотой 4-12 МГц.

Результаты исследования. По результатам исследования, мы выявили: асимметрию толщины периферической зоны - 5 (33,3\%) исследований; асимметричную гиперплазию транзиторных 3он - 4 (26,67\%); участки скопления микрокальцинатов - 3 (20\%); деформацию «хирургической капсулы» простаты - 1 (6,67\%); локальную деформацию сосудистого рисунка в зоне железы - 1 (6,67\%); локальную деформацию капсулы и «пограничного слоя» простаты - 1 (6,67\%). Сопоставив признаки, выявленные при ТРУЗИ, чувствительность метода составила 91,5\%, специфичность - 92,3\%, точность метода - 90,9\%.

Выводы. Выявлены и систематизированы косвенные признаки рака простаты, из них наиболее частым спутником раннего рака являются: асимметрия толщины периферической зоны, асимметричная гиперплазия транзиторных зон, участки скопления микрокальцинатов, деформация «хирургической капсулы» простаты, локальная деформация сосудистого рисунка в режиме энергетического допплеровского картирования в проекции гипо и даже изоэхогенных очагов в железе, локальная деформация капсулы и «пограничного слоя».

\section{Список литературы:}

1. Руденко О.В., Сафонов Д.В., Рыхтик П.И., Гурбатов С.Н., Романов С.В. Физическиеосновыэластографии. Часть

2. Эластография на сдвиговой волне (лекция) // Радиология-Практика. - 2014. - № 4 (46). C. $62-71$. 


\title{
ОПТИМИЗАЦИЯ ЛЕЧЕНИЯ КЛИНОВИДНЫХ ДЕФЕКТОВ ТВЁРДЫХ ТКАНЕЙ ЗУБОВ У БЕРЕМЕННЫХ ЖЕНЩИН.
}

\author{
Муродова М.К., Сафаров М.Т., Нарзиев И.К. \\ Ташкентский Государственный Стоматологический Институт \\ Кафедра Госпитальной Ортопедической Стоматологии
}

Цель: изучение эффективности протезирования винирами при дефектах коронковой части зубов беременных женщин.

Актуальность темы: Использование комплекса современных диагностических и аналитических методов дает возможность объективно правильно поставить клинический диагноз и прогнозировать результат ортопедического лечения.

В настоящее время стоматологи всё чаще прибегают к винирам при лечении клиновидных дефектов эстетических дефектов зубов у беременных женщин.

Виниры - тонкие пластинки толщиной 0,5 - 0,7 мм, которые фиксируются на вестибулярные поверхности зубов. Виниры - это лучший способ коррекции, в том числе и возрастных изменений зубов. Благодаря винирам можно скрыть дефекты коронковой части зуба кариозного и некариозного происхождений, исправить аномалии формы, размера и положения зуба в зубном ряду, а также, при изменении цвета зубов различной этиологии. Современные накладки хорошо выдерживают температурные перепады, не изменяются в цвете от употребления чая, кофе и напитков с красителями, не мутнеют. Единственный минус - для установки виниров требуется препаровка зубов. Толщина сошлифовывания твердых тканей равна толщине винировой пластинки. Устанавливаются виниры в несколько посещений стоматолога. После установки пациент приобретает натуральную естественную улыбку. Срок службы виниров по данным различных авторов достигает до 10 лет при должностном уходе за ними.

Материалы и методы исследования: Обследовались больные в возрасте от 20-35 лет. Из них 22 женщин с различными сроками беременности. Из них было выявлено нами 13 женщин с диагнозом клиновидный дефект; 7 женщин с патологической стираемостью зубов (резцы и клыки), 2 женщины с нарушением цвета зубов (тетрациклиновые зубы).

Результаты собственных исследований: В первое посещение стоматолога снимались слепки для компьютерного моделирования будущей улыбки. Во второе посещение проводилась примерка и непосредственно установка люминиров, т.е. этот процесс происходит всего в два посещения стоматолога. Срок службы люминиров зависит от вида прикуса, величины коронковой части зубов, гигиенической мотивированности пациента и т.д. Виниры мы условно разделяли на 2 типа в зависимости от метода их установки.

При выраженности экваториальной части коронки зуба, при наличии диастем и трем, на крупных зубах виниры мы устанавливали после предварительной препаровки зубов. Препарирование является очень важным этап при изготовлении любых несъемных реставраций, в том числе и керамических виниров. Препарирование зубов под непрямые виниры производилось тремя способами: 1. дизайн препарирования, предусматривающий сохранение интактного режущего края зуба; 2 . Дизайн, предусматривающий сошлифовывание режущего края без создания уступа с небной поверхности зуба; 3. Дизайн, предусматривающий сошлифовывание режущего края с созданием уступа с небной поверхности зуба. Первый дизайн препарирования показан при сохранении целостности режущего края. Прочностные характеристики зуба при таком препарировании снижаются незначительно [Castelnuovo, 2018]. Количество твердых тканей сошлифованных с вестибулярной стороны определяют способность будущего винира изменять цвет подлежащих тканей. Omar et al в 2017 году доказал, что увеличение толщины слоя керамики с 0,5 до 0,7 мм увеличивает маскирующую способность адгезивной облицовки незначительно. Но при толщине 0,3 мм маскирующие свойства винира выражены слабо. Дизайн, предусматривающий сошлифовывание твердых тканей режущего края без создания уступа с небной поверхности зуба, показан при нарушении целостности режущего края коронки зуб вследствие кариеса, травмы, повышенной стираемости и других некариозных поражений.

Сошлифовывать твердые ткани в области режущего края рекомендуется не менее 1 мм., так как меньшая толщина керамической облицовки увеличивает риск перелома винира в 
этой области [Touati, 2016], увеличение редукции до 3 мм и более так же увеличивает риск повреждения адгезивной облицовки под действием жевательной нагрузки [Castelnuovo, 2020]. Создание уступа с небной поверхности зуба значительно увеличивает прочность реставрации при циклических нагрузках [Chaiyabutr, 2019], уменьшает количество путей введения винира, следовательно, и вероятность дебондинга [Shillinburg, 2019], позволяет разместить границу препарирования за границами окклюзионного воздействия [Touati, 2018]. Но также создание небного уступа уменьшает качество краевого прилегания винира по сравнению с препарированием без редукции режущего края и препарированием с редукцией режущего края без создания уступа с небной стороны [Stappert, 2017]. Дополнительные сложности возникают при препарировании пораженных зубов, с убылью твердых тканей в результате повышенной стираемости, эрозивных процессов и других некариозных поражений зубов. В этих случаях контуры будущей реставрации больше, чем имеющиеся твердые ткани зуба, что требует изменение методики препарирования, так как необходима меньшая редукция твердых тканей при препарировании. Большую диагностическую ценность в таких случаях приобретает такие диагностические процедуры как Wax Up и Mock up [Magne, 2016].

Выводы. Виниры являются современным и эффективным способом эстетических недостатков естественных зубов. Использование виниры позволяет избежать длительного восстановления, делая улыбку безупречной. Применение виниров позволяет восстанавливать форму, цвет и степень смыкания зубов в полном объёме. Эта методика позволяет проводить щадящую тактику при восстановлении различных дефектов коронковой части зубов. 


\section{ЮРАКНИНГ РЕВМАТИК КАСАЛЛИГИДА ТЕРАПЕВТИК ТАКТИКА ВА ПРОФИЛАКТИК ЁНДОШУВЛАР САМАРАДОРЛИГИНИ ОШИРИШ ЙЎЛЛАРИ.}

\section{Ризамухамедова М.З., Ширанова Ш.Ш.} Тошкент Тиббиёт Академияси.

Қон айланиш етишмаслигининг юзага келишидаги сабаблар ичида ЮРИ марказий ўринлардан бирини эгаллайди. АҚШдаги фремингем текширишлари натижалари бўйича СЮЕ сабаблари ичида юракнинг клапан нуқсонлари тўртинчи ўринни эгаллайди, Европа мамлакатларида эса- учинчи.

Кейинги ўн йилликларда ҚАЕли беморларнинг хаёт давомийлиги узайганлиги қайд этилди, бу эса клиник амалиётга ААФИ ларининг кириб келиши билан боғлиқ. Кардиологиянинг сўнги икки ўн йилликда эришган ютуқларига қарамасдан, ҚАЕ аввалдагидек қон-томир тизимининг энг кенг тарқалган, оғир ва прогнози ёмон асоратларидан бўлиб қолмокда.

Чап қоринчанинг патологик ремоделяциясининг прогрессирланишини фақатгина нейрогормонларнинг юқори фаоллиги билан тушунтириб бўлмайди, ҚАЕ нинг «Цитокин» модели нейрогормонлар ролини ўрганилганда олинган маълумотларни тўлдирди.

ААФИ ларини ревматик этиологияли ҚАЕ ни даволашда кўлланилиши ва уларни ревматик этиологияли ҚАЕ ни даволашда кўлланилиши ва уларнинг цитокинлар фаоллашувига таъсири етарлича ўрганилмай қолмоқда. Шунинг учун лизиноприлнинг гемодинамик кўрсаткичларга таъсири ва цитокинларнинг ЮРИ ли ҚАЕ беморларда ( С.Д. Стражеско ва В.Х. Василенко бўйича) ўрганилди.

91та 17-56 ёшдаги беморлар танлаб олинди: митрал ЮРИ билан 54 ва аортал ЮРИ билан 37 та. РИ ва ЮРК -Россия тиббиёт фанлари академиясининг Ревматология институти таклиф этган мезонлар асосида диагноз кўйилди. ҚАЕ босқичларини С.Д.Стражеско ва В.Х.Василенко (1964) таснифи бўйича аниқланди. ҚАЕ II А босқичи 54 та беморда (59,3\%), II Б босқичи 37 та беморда (40,7\%) борлиги аниқланди.

ҚАЕ нинг II А босқичини белгилашда беморларда кузатилган харакатдаги хансираш, юракнинг тез уриши, хаво етишмаслик холати, цианоз, акрацианоз, тахипноэ, ёстиқнинг баланд кўйилиши каби аломатларга асосланди. Айни пайтда даволаш динамикасида ахамият берилди.

Беморлар 2 гурухга рандомизирланди. І-гурухга 46 бемор киритилиб (28та бемор митрал клапан етишмаслиги билан ва 18та бемор аортал клапан етишмаслиги билан), улар стандарт даво қабул қилдилар (диуретиклар, юрак гликозидлари ва кўрсатмага асосан вазодилятаторлар, антиаритмик препаратлар).

II-гурухга 45та бемор киритилиб (26та бемор митрал клапан етишмаслиги ва 19 та бемор аортал клапан етишмаслиги билан), улар стандарт терапияга қўшимча лизиноприл қабул қилдилар. Лизинаприл 2,5-5 мг дан суткасига 1 махал дозани аста-секинлик билан 10-20мг гача ошириш орқали 3 ойгача берилди. Даволашга ААФИ кўшилгандан кейин даволашнинг дастлабки 15 кунидаёқ анъанавий давога нисбатан хансираш, юракнинг тез уриши, акрацианоз аломатлари 1,5 маротаба камайди. Беморларнинг барчасида хаво етишмаслик туфайли тунги уйқунинг бузилиши кузатилмади. ЭхоКГда чап бўлмача хажми, чап қоринчанинг охирги диастолик размери ва охирги систолик размери, чиқариш фракцияси , қисқариш фракцияси , қоринчалараро тўсиқ қалинлиги , ЧҚнинг орқа девори қалинлигини ва ЧҚ миокард массаси қайд этилди.

Анъанавий даво бошлангандан 3 ой кейин митрал ва аортал ЮРП ли беморларда ЧБ, ЧҚнинг ОСР ва ихирги систолик хажми , ОДР ва охирги диастолик хажм , ЧҚММ ортишига йўналиши қайд этилди. Шу билан бирга ЧФ ва ҚФ камайиши кузатилди.

Митрал ва аортал ЮРИ ли беморлар цитокин профиллари қон зардобида текширилганда жиддий ва кўп йўналишли ўзгаришлари аниқланди.

Митрал юрак иллати беморларда анъанавий даводан сўнг про- ва яллиғланиш цитокинларнинг қондаги миқдори сезиларли ўзгармади, аортал юрак иллатли беморларда эса, аксинча, дастлабки микдорига нисбатан ИЛ-6 - 14,8\%га, ЎНО- $\alpha$ - 9\% ортишига тенденция кузатилди.

Шундай қилиб, айтиш мумкинки, анъанавий даво ЧҚ хажмий кўрсаткичларини ва ЧҚ миокарди қисқариши имкониятларини яхшиланишига олиб кела олмади, цитокинлар компонентлари ўртасидаги дисбаланс эса янада чукурлашди. Ушбу ўзгаришлар шубхасиз, СЮРКнинг 
кечишига салбий таъсир кўрсатади.

Текширишнинг учинчи ойига келиб, лизиноприл билан даволаш фонида ЧҚнинг размерлари (ЧҚОДҚ, ҚАТҚ, ЧҚММ) ва хажмий кўрсаткичларининг статик ишончли камайишига ва яллиғланиш цитокинлари кўрсаткичларининг кескин камайиши, хамда ЧФ, ҚФ нинг ортишига олиб келди.

Бизга маълумки, компенсатор механизмларнинг камайишида юракдан қоннинг чиқарилиши пасаяди. Юракдан қоннинг чиқарилишини нормал холда сақланиши учун симпатоадренал ва ренин-ангиотензин-алдостерон тизими нейрогармонларининг фаоллашуви қўшилади ва бу тахикардияга, периферик томирларнинг констрикцияси в.б.ларга олиб келади. Тўқима нейрогармонларининг сурункали гиперфаоллашуви юракнинг ремодуляциясига олиб келади. ААФИ ангиотензин II синтезини қамал қилиб, вазодилатацияга олиб келади ва юракнинг олд- ва кейинги юкланишини камайтиради. ААФИ ангиотензин II, алдостерон, антидиуретик гармон ва катехоламинлар сатхини пасайтиради. ААФИ билан даволашда вазоактив бирикмаларининг баланси томир кенгайтирувчи биологик фаол моддалар фойдасига ўзгаради, бу эса кининаза фаоллиги чекланиши ва брадикининнинг миқдори ортиши хисобига брадикинин ва кининаза фаоллигининг чекланиши натижасида юзага келади.

Кўриб турганимиздек, ААФИ нинг кўлланилишида ЮРИ ли беморлар қонида цитокинларнинг ортиқча миқдорининг пасайиши кузатилди. Лизиноприл билан комплекс даво ўтказилганидан кейин прояллиғланиш цитокини ИЛ-6 миқдори митрал иллатли беморларда деярли 1,3 марта, аортал иллати беморларда эса 1,9 марта анъанавий даво олган беморлар назорат гурухига нисбатан кўпроқ камайган. ЎНО- $\alpha$ концентрацияси 1,2 марта камайди, лекин бу кўрсаткичлар соғлом одамлар кўрсаткичидан ишончли даражада фарқ қилади $(\mathrm{P}<0,01)$. Шунингдек яллиғланишига қарши цитокин ИЛ-10 нинг комплекс даво олмаган гурух кўрсаткичларига нисбатан деярли 1,5 марта (P<0,01) камайганини қайд этиш мумкин.

Маълумки, цитокинлар юрак -қон томир тизими фаолиятини модуллаштириши мумкин, бунда ҚАЕ нинг марказий ва периферик белгиларини юзага келтиради. Яллиғланишга қарши цитокинларнинг нохуш таъсирларидан бири бўлиб, уларнинг салбий инотроп таъсирлари, юракнинг ремоделирраштириши, кардиомиоцитлар ва периферик мушаклар апоптозини жадаллаштириш хисобланади.

Шундай қилиб, лизиноприл ревматик этиологияли ҚАЕ ни даволашда самарали бўлиб, у гемодинамика кўрсаткичларига ижобий таъсир қилади ва жисмоний юкламага толерантлилигини оширади, хамда цитокинлар (ЎНО- $\alpha$, ИЛ-6, ИЛ-10)нинг ортиқча микдорини камайтиради. 


\title{
ОСОБЕННОСТИ КЛИНИЧЕСКИХ И ЛАБОРАТОРНЫХ ИССЛЕДОВАНИЙ ПРИ БРОНХИАЛЬНОЙ АСТМЕ У ДЕТЕЙ ПЕРЕНЕСШИХ COVID - 19
}

Ташматова Гулноза Аълоевна

Ташкентская медицинская академия

\begin{abstract}
Актуальность. Одним из приоритетных направлений исследований COVID-19 является идентификация факторов риска тяжелого течения новой коронавирусной инфекции. Неоднозначность мнений по проблеме сочетания бронхиальной астмы (БА) и Covid-19 вызывает интерес исследователей и клиницистов во всем мире. Авторы поддерживают существующие в настоящее время рекомендации по продолжению базисной противовоспалительной терапии БА, включая прицельное воздействие таргетными препаратами и ранее инициированную терапию системными и топическими глюкокортикостероидами при инфекционном процессе, вызванном SARS-CoV-2.
\end{abstract}

Целю исследования изучение особенностей анамнеза, клинической картины, результатов лабораторных исследований детей с бронхиальной астмой перенесших COVID - 19.

Материал и методы. В ходе работы обследовано 62 детей с бронхиальной астмой приболевший Covid - 19. Использовались клинические, лабораторные и инструментальные методы диагностики, определялся уровень общего IgE в сыворотке крови.

Результаты. В обследуемой группе детей у 33 (53,2\%) пациентов БА имела легкое течение, $17(27.4 \%)$ детей имели БА средней степени тяжести, у 12 (19.3\%) детей были БА тяжелый степени. Давность заболевания менее 3 лет наблюдалась у 24 (38.7\%) детей, более 3 лет у 34 (54.8\%) детей. Первый раз установленный диагноз БА у 4 (6.4\%). Наследственную отягощенность по аллергопатологии имели 33 (53.2\%) детей. Нарушения по обструктивному типу при проведении спирометрии установлены у 16 (25.8\%) детей с БА средней степени тяжести. Сопутствующая патология выявлена у $46(74.2 \%)$ детей, достоверно чаще (p<0,05) БА сочеталась с каким-либо другим аллергическим заболеванием. Эозинофилия в общем анализе крови выявлена у 41 (66,1\%) детей. Повышение уровня общего IgE (более 100 KЕ/л) в сыворотке крови наблюдалось у 51 (82.2\%) детей.

Заключение. В результате проведения клинических и лабораторных исследований при бронхиальной астме у детей перенесших covid-19 выявляются различные особенности, что следует учитывать при постановке диагноза БА, а также для дальнейшего выбора адекватной терапии. 


\title{
BASIC STRATEGIES OF BLENDED LEARNING IN THE MODERNIZATION OF THE SYSTEM OF PHILOLOGICAL HIGHER EDUCATION IN UZBEKISTAN
}

\author{
Azizov Solijon Uchmas $0^{6} \mathrm{~g}^{6} \mathrm{li}$ \\ $\mathrm{PhD}$ student, Uzbekistan State World Languages University \\ Tashkent, Uzbekistan \\ E-mail: solijonazizov1@gmail.com
}

\begin{abstract}
"We consider the family, preschool, school and higher education, as well as scientific and cultural institutions to be the most important links in the future Renaissance. Therefore, we are consistently carrying out radical reforms in these areas".
\end{abstract}

Sh. Mirziyoyev

Annotation. Blended learning is considered to be one of the best ways of creating the teaching and learning environment convenient and save for those who study and work at higher education in general during the COVID-19 pandemic. In this article, basic strategies of blended learning are illustrated based on the theoretical and practical results of the investigation on this matter in the example of the system of philological higher education in Uzbekistan.

Key words: blended learning, teaching strategy, higher education, student motivation, model, classroom design, optimization.

Given that the COVID-19 pandemic has remarkably brought a number of changes into a human's life, the sphere of education has started to be redesigned based on more innovative means and technologies in the world. Consequently, offline and online platforms of education have become basic areas of scientific investigations according to the methodological points of views. For instance, blended learning plays an important role in optimizing and modernizing the system of philological higher education if basic strategies of this approach are implemented into practice right by taking all the theoretical and practical basis into consideration deeply.

By implementing the strategies of blended learning into the system of teaching foreign languages at higher education, both a teacher and students (language learners) can work much more cooperatively than just studying only offline or online. Strategies can be set by a teacher of a foreign language individually as the effectiveness of the whole process depends on him or her being able to follow them right. The following strategies of blended learning can be applied into the process of teaching and learning foreign languages at philological higher education [2]:

- Goals (problems) of the process of improving skills must be identified in advance. It is well-known that there are different types of language learners whose levels in the target language are various at higher education. Besides that, students can have certain types of problems in improving their linguistic skills in the process of learning the target language which can affect the productivity of the applied methods, techniques, and approaches by the teacher. Therefore, a teacher should identify problems or weak points that students have before implementing the blended learning strategies for which a teacher can use certain types questionnaires, tests or activities to realise real problems during lessons.

- Materials of the lessons in the target language must be prepared in a systemic way. Successful results can be achieved in teaching foreign languages when the materials, such as multimedia sources, handouts, tasks are prepared by the teacher by taking all the factors which may appear during the lessons into account fully. According to the objectives of the research on this matter, the factors of quality, content, connectedness, and continuousness must be significant elements while presenting the materials in the target language based on the theoretical and practical basis of blended learning.

- Students' motivation must be taken into account in the process. As the writing competence as an example in a foreign language involves language learners to practice writing skills much more rather than the other skills, this situation may result in students' losing their interest in the lessons. Hence, a teacher can utilize various techniques to keep students motivated in blended learning. 
For instance, on the virtual platforms of the lessons, a teacher can present innovative means of testing students' knowledge, skills and providing them with digital forms of assessment and feedback.

- A teacher must be in the centre of the whole process. Strategies of blended learning involve a teacher to control the whole process of teaching and learning foreign languages. Lessons of the writing competence can be taken as an example for this strategy - a teacher presents tasks, materials on a virtual platform before a traditional lesson and continues fostering the competence by working with students at university or vice versa.

- Platforms of blended learning must be easy to use and implement for both a teacher and students. Blended learning aims to assist a teacher to resolve problems in teaching foreign languages and to create the convenient environment for students to foster their linguistic skills effectively. Taking this factor into account, it must be mentioned that virtual platforms of blended learning, for instance, on fostering the writing competence must be easy to use for students in order not to make the process problematic to achieve goals.

- A well-set and effective model of blended learning must be implemented into practice. It can be said that blended learning enables a teacher to create his or her individual model taking their own experiences and methods of teaching foreign languages into account, thereby making the process of applying blended learning into the system of teaching foreign languages at philological higher education in Uzbekistan.

To conclude, the present-day system of teaching foreign languages like the rest spheres of education demands that both a teacher and language learners to work cooperatively which can be achieved by following the strategies of blended learning in a systematic way. As a result, the process of modernizing and optimizing the system of fostering linguistic skills can meet the requirements of digital education.

\section{References:}

1. Speech of the President of the Republic of Uzbekistan Shavkat Mirziyoyev at the Youth Forum of Uzbekistan - Newspaper "Xalq so“zi” № 273 (7775), 26.12.2020.

2. https://edtechnology.co.uk/latest-news/ultimate-guide-to-blended-learning/ 


\title{
EDUCATIONAL VALUE OF "SORROWS OF TURKESTAN" BY ALIKHANTORA SOGUNI
}

\author{
D.B. Mamadjanova \\ Master of Tashkent State Pedagogical University \\ named after Nizami
}

\begin{abstract}
Annotation: The article tells about the life and work of the historical figure, the great scientist Alikhantora Soguni, about the pedagogical and educational significance of his work.

Key words: Alikhantora Soguni, upbringing, education, ideas of freedom, scientific heritage, national history.
\end{abstract}

Alikhantora Soguni is a patriotic, perfect man of the 20th century, one of the great scientists who mastered many sciences, his teachings about patriotism and the development of the country are of great importance in the field of education. The historical work "Sorrows of Turkestan" occupies a special place among the great scientific heritage written by Alikhantor Soguni over the last 30 years of his life. This work is one of the historical, educational, rare works. The work is written in an autobiographical spirit, imbued with the author's life lines and tells about the brave who sacrificed their lives for the people around him. "The words of my pen were added to my bloody tears and spilled on the pages of this book. Therefore, I called it "Sorrows of Turkestan", - writes Soguni at the beginning of his work. This work by Alikhantor Soguni is a living history. It has no texture or fantasy. The events and names of people in the work are clear and true.

The main reasons why our country and nation have been in the hands of invaders and colonial oppression for more than a hundred years are disunity in Turkestan, enemies of science and culture who do not understand religion, and inattention to the country's defense. , the darkness of the superstitions of our people, and Soguni complained that he completely plunged into the swamp of ignorance and did not pay attention to the study and teaching of modern sciences.

"Why did the Turkestan people plunged into such a swamp of ignorance in the following centuries? The main reason for this was that the enemies of science and culture, who did not understand the foundations of religion, came to power. By declaring themselves patrons of religion, they deprived people of the light of enlightenment and completely distanced themselves from modern science. They did not communicate with foreign countries, did not pay attention to education. As a result, Turkestanis were unable to wake up, open their minds and take advantage of the situation. The crisis of the state is the cause of the ignorance of the nation.

From the above, it is clear that the leaders of that time, who misinterpreted our religion, did not promote science and culture in society, prohibited modern science, kept people from enlightenment, did not interact with developed countries. the example of their experience led to the crisis of the state and the stagnation of the consciousness of the nation.

"Therefore, let the children of the Motherland, remembering the coming days, with all their hearts begin to study modern science and hold on to their honest heritage in order to prepare the defense forces for the occupation of their Motherland."

Alikhantora Soguniy said that young people should comprehensively engage in science, master modern techniques and technologies, as well as educate the people of national feeling, preserve their native language and literature. They say that the need to preserve them is one of the factors: "Our educated and understanding children of the Motherland cannot benefit us, that is, their people, if they do not have a national feeling. Maybe they will be a tool to carve and dry our roots in the hands of the enemy, like we carved an ax out of ourselves. In this case, they will dig deep to bury the people of their homeland at the hands of the sons of their homeland."

Soguni considers the national language to be the main link of the national feeling. He believed that the higher the value of the native language, the higher the status of the world, the preservation of the national feeling, the loss of the native language, the loss of the national feeling.

"Even if we temporarily separate from our national power, if we can separate it from our national feelings, we can save ourselves from being swallowed up by our enemies in the future. So, the first condition for achieving this goal is language. If we expand our language literature, increase its value and bring it to the level of other cultural languages, then our nation, our national feelings will continue to grow. If this is not so, but on the contrary, if they do not pay attention to their native language, 
without realizing it, then they will soon say goodbye and forever be parted from their language. This fact must be taken into account. "

He added: "Since then, our schoolchildren have not been taught the religion of Islam due to their lack of religious education. Therefore, even if the children of the Motherland are not allowed to receive religious education, they can no longer be separated from language education in order to preserve their nationality. Because when a nation separates from its religion and loses its language, its nationality is absorbed and its life is in a state of crisis. " he said.

"Just as everyone has a duty to study theology, so everyone has a duty to study modern science in order to preserve their government, homeland and nation," he said, adding that "our boys and girls are well versed in all modern sciences. science "they need to understand and learn as much as possible. Because, fulfilling the words of the wise fathers:" Work is for the knowledgeable, the sword is for the hitters, "the people of the Motherland, especially our modern educated sons and daughters, will do their job and take their rightful place. . They can. "

From the above thoughts of Soguni, we can conclude that he showed that it is permissible not only to receive a religious education, but also to acquire secular, modern knowledge, as well as acquire new knowledge for the development of society and the state.

Soguni strongly condemns ignorance, ignorance, both as human catastrophes:

"An ignorant, ignorant nation is no different from a herd of animals that is driven into a birdhouse in front of its enemies. Man's closest enemy to himself is ignorance."

Soguni's teachings are a great spiritual heritage in the upbringing of modern youth in the spirit of high spirituality, morality and love for the Motherland. We must deeply study the life and work of one of our great ancestors, Alikhantor Soguni, not forgetting his services to the Motherland and our people, and call them one of our progressive ancestors.

\section{List of used literature:}

1. Alikhantora Soguni. "The Sorrow of Turkestan". T., 2012

2. Alikhantora Soguni. "History of Muhammadiy" .T., Movarounnahr, 2017 


\title{
DIFFICULTIES OF TRANSLATING IDIOMS AND PHRASEOLOGICAL UNITS
}

\author{
Gulchehra Rahmanova, \\ Andijan state university, Uzbekistan \\ Mavluda Uliqova, \\ Andijan state university, Uzbekistan
}

\begin{abstract}
Аннотация: Статья посвящена анализу трудностей перевода идиом и фразеологических единиц с родного языка на иностранный и наоборот.

Ключевые слова: идиома, фразеологические единицы, реалии, дословный перевод, устойчивое выражение.

Annotation: The present article is devoted to the analysis of difficulties in translation of idioms and praseological units from L1 to L2 (from mother tongue to foreign language or source language to target) and vice versa.
\end{abstract}

Key words: idiom, phraseological units, realms, word - for - word translation, fixed

As we know, translating idioms or phraseological units from one language into another is challenging issue. Word-for-word translation can lead to misunderstandings and the loss of meaning in target language.

As far as idioms and phraseological units are concerned in translation, the first difficulty that a translator comes across is being able to recognize that she/he is dealing with an idiomatic expression. This is not always so obvious. There are various types of idioms, some more easily recognizable than others. Those which are easily recognizable include expressions which violate truth conditions, such as: It's raining cats and dogs, throw caution to the winds, storm in a tea cup, jump down someone's throat, and food for thought. They also include expressions which seem ill-formed because they do not follow the grammatical rules of the language, for example, trip the light fantastic, blow someone to kingdom come, put paid to, the powers that be, by and large, and the world and his friend. Expressions which start with like (simile-like structures) also tend to suggest that they should not be interpreted literally. These include idioms such as like a bat out of hell and like water off a duck's back. Generally speaking, the more difficult an expression is to understand and the less sense it makes in a given context, the more likely a translator will recognize it as an idiom. Because they do not make sense if interpreted literally, the highlighted expressions in the following text are easy to recognize as idioms (assuming one is not already familiar with them): This can only be done, I believe, by a full and frank airing of the issues. I urge you all to speak your minds and not to pull any punches.

Once an idiom or fixed expression has been recognized and interpreted correctly, the next step is to decide how to translate it into the target language. The main difficulties involved in translating idioms and fixed expressions may be summarized as follows:

(a) An idiom or fixed expression may have no equivalent in the target language. The way a language chooses to express, or not express, various meanings cannot be predicted and only occasionally matches the way another language chooses to express the same meanings. One language may express a given meaning by means of a single word, another may express it by means of a transparent fixed expression, a third may express it by means of an idiom, and so on. It is therefore unrealistic to expect to find equivalent idioms and expressions in the target language as a matter of course.

Idioms and fixed expressions which contain culture-specific items are not necessarily untranslatable. It is not the specific items an expression contains but rather the meaning it conveys and its association with culture-specific contexts which can make it untranslatable or difficult to translate. For example, the English expression to carry coals to Newcastle, though culture-specific in the sense that it contains a reference to Newcastle coal and uses it as a measure of abundance, is nevertheless closely paralleled in Russian by в Тулу со своим самоваром. Both expressions convey the same meaning, namely: to supply something to someone who already has plenty of it.

(b) An idiom or fixed expression may have a similar counterpart in the target language, but its context of use may be different; the two expressions may have different connotations, for instance, or they may not be pragmatically transferable. To sing a different tune is an English idiom which means to say or do something that signals a change in opinion because it contradicts what one has said or done before. To go to the dogs ('to lose one's good qualities') has a similar counterpart in German, but whereas the English idiom can be used in connection with a person or a place, its German counterpart 
can only be used in connection with a person and often means to die or perish.

(c) An idiom may be used in the source text in both its literal and idiomatic senses at the same time. Unless the target-language idiom corresponds to the source-language idiom both in form and in meaning, the play on idiom cannot be successfully reproduced in the target text.

(d) An idiom or fixed expression may have a similar counterpart in the target language, but its context of use may be different; the two expressions may have different connotations, for instance, or they may not be pragmatically transferable. An idiom may be used in the source text in both its literal and idiomatic senses at the same time. Unless the target-language idiom corresponds to the sourcelanguage idiom both in form and in meaning, the play on idiom cannot be successfully reproduced in the target text.

Fernando and Flavell discuss the difference in rhetorical effect of using idioms in general and of using specific types of idiom in the source and target languages and quite rightly conclude that "Translation is an exacting art. Idiom more than any other feature of language demands that the translator be not only accurate but highly sensitive to the rhetorical nuances of the language".

It can be concluded that a translator while translating idioms, phraseological units or realms (terms which are related to a certain language) should be aware of not only the target language but its culture as well. Besides, we have learnt that it's impossible to translate idioms without knowing specific vocabulary and using dictionaries.

\section{Literature:}

1. Baker, M. (1992). In other words: A Coursebook on Translation. Location: Publisher;

2. Bassnett, S. (1980). Translation Studies. London: Methuen \& Co. Ltd;

3. Belloc, H. (1931). On Translation. Oxford: The Clarendon Press;

4. Snell-Hornby, M. (1988). Translation Studies: An Integrated Approach. Amsterdam: John Benjamin. 


\title{
DIDACTIC OPPORTUNITIES OF DISTANCE LEARNING TECHNOLOGIES IN THE ORGANIZATION OF INDEPENDENT EDUCATIONAL ACTIVITIES OF STUDENTS.
}

\author{
Hayitova Iroda Ilhomovna \\ Bukhara Institute of Engineering and Technology. \\ ilhomovna82@bk.ru
}

\begin{abstract}
Annotation. In modern conditions, there is a need to form a flexible distributed system of lifelong learning, through which a person can access global information resources and databases, constantly improve their professional skills and become professionally mobile and creatively active. A promising education system should not only equip students with knowledge, but also shape the need for continuous independent learning due to the constant and rapid updating of knowledge in our time, as well as help to develop an independent and creative approach to knowledge during active life.

Keywords: independent learning, distance learning, modern teaching technologies, pedagogical problem.
\end{abstract}

Promising education system is not only equipped with the knowledge of the reader, but in modern times, constantly and frequently updated because they form a continuous need for the development of an independent, as well as during the active life of human knowledge should contribute to the development of an independent and creative approach. All this leads to the need to introduce new technologies and forms of teaching. Let's define the meaning of the basic concepts in the following sequence: distance learning - "distance learning technologies - didactic possibilities of distance learning technologies in the organization of independent learning activities of students.

Distance education is a modern universal form of vocational education, focused on the individual needs of students and their specialization. This form of education has become a topic of active study by foreign and Uzbek researchers.

Before considering the didactic possibilities of distance learning technologies in the preparation of students, we will analyze the essence of the concept of "distance learning" in general and as a pedagogical problem in particular. There are versions such as "distance learning" and "distance learning" that have emerged in connection with the translation of phrases used abroad.

Synthetic, integrated, humanistic form of education based on the widespread use of traditional and new information technologies, their technical means used for the delivery of distance learning materials, its independent study, the organization of communication between teachers and students".

Distance learning is a new phase of distance learning that provides access to information technology based on the use of personal computers, video and audio equipment.

The concept of distance learning here is probably one of the most qualified experts in the field - experts from the American Distance Learning Association. through distance learning, association professionals understand the geographically segregated learning process of teacher and pupil or students and therefore rely on electronic tools and printed guides to organize the learning process. Distance learning includes distance learning and distance learning (learning activities of students), i.e. the teacher and the student are involved in the learning process. The main factors determining distance learning:

1) separation of teachers and students, at least for a large part of the educational process;

2) the use of educational tools to combine the efforts of teachers and students and ensure the mastery of course content;

3 ) ensuring interactivity between teacher and students, course management and students;

4) The advantage of self-control over teacher supervision.

Here is a table of the most important for pedagogical terms of distance learning (Table 1). 


\section{Table 1. Terms used in distance learning}

\begin{tabular}{|c|c|c|}
\hline \multirow{2}{*}{ Definitions of the authors } & \multicolumn{2}{|l|}{ Phrases } \\
\hline & Distance education & Distance learning \\
\hline Е.С.Полат & $\begin{array}{l}\text { Interaction between teacher and students at a distance carried } \\
\text { out by all components specific to the learning process (goals, } \\
\text { content, methods, organizational forms, teaching aids), } \\
\text { specific tools of Internet technology or others that provide } \\
\text { interactivity. }\end{array}$ & There is no definition \\
\hline $\begin{array}{l}\text { Teams of MO project } \\
\text { specialists }\end{array}$ & $\begin{array}{l}\text { All or most of the teaching procedures are conducted using } \\
\text { modern information and telecommunication technologies, } \\
\text { with the territorial separation of teachers and students. }\end{array}$ & $\begin{array}{l}\text { Education through } \\
\text { distance learning }\end{array}$ \\
\hline $\begin{array}{l}\text { On the portal «Russian open } \\
\text { education» }\end{array}$ & $\begin{array}{l}\text { A form of physical separation of time and space that differs } \\
\text { in the use of distance learning technologies by teachers and } \\
\text { students }\end{array}$ & $\begin{array}{l}\text { Form of education on } \\
\text { methods and means of } \\
\text { distance learning }\end{array}$ \\
\hline $\begin{array}{l}\text { Eidos Center, authored by } \\
\text { A.V Khutorskoy }\end{array}$ & $\begin{array}{l}\text { Teaching with the help of telecommunications, in which the } \\
\text { subjects have a spatial or temporal distance, carries out a } \\
\text { general educational process that corresponds to the creation } \\
\text { of external educational products and internal changes of } \\
\text { educational subjects }\end{array}$ & $\begin{array}{l}\text { The superiority of } \\
\text { distance learning } \\
\text { technologies, forms, } \\
\text { methods and means } \\
\text { of teaching in the } \\
\text { educational process, } \\
\text { as well as education } \\
\text { using information and } \\
\text { educational resources of } \\
\text { the Internet }\end{array}$ \\
\hline MESI team of experts & $\begin{array}{l}\text { Distance learning technology where teachers and students } \\
\text { are physically located in different places. Previously, } \\
\text { distance learning meant distance learning. Now Case is a } \\
\text { learning tool that uses TV and network learning technologies }\end{array}$ & $\begin{array}{l}\text { Human education that } \\
\text { occurs in the process of } \\
\text { interaction with distance } \\
\text { learning resources } \\
\text { and subjects using } \\
\text { information technology } \\
\text { and telecommunications. }\end{array}$ \\
\hline DO IOSO RAO laboratories & $\begin{array}{l}\text { A form of education in which the teacher and the student } \\
\text { interact with each other remotely and reflect all the } \\
\text { components (goals, content, methods, organizational forms, } \\
\text { teaching aids) that are specific to the learning process. }\end{array}$ & $\begin{array}{l}\text { Education through } \\
\text { distance learning. }\end{array}$ \\
\hline
\end{tabular}

Distance education allows everyone to constantly improve their professional level: individual characteristics: in the process of such training the student spends some time independently learning educational materials in an interactive mode with other students of the «virtual» group, takes tests, supervises under the guidance of a teacher and collaborate.

Conclusion: Thus, distance learning, distance learning using information and communication technologies, promotes close collaboration between student and teacher; is the process of delivery of learning materials, its independent study and continuous independent learning activities of students.

\section{References}

1. Polat E.S., Moiseeva M.V., Petrov A.U., Buxarkina M.Yu., Aksenov Yu.V., Gorbunkova T.F. Distantsionnoe obuchenie. $-\mathrm{M}$.: VLADOS, 1998, $304 \mathrm{p}$.

2. Tuninga R.S., Seinen I.B. The Supple and Demand of Distance Education in Russia / - The World Bank, Bureau Cross, 2000.- 110 p.

3. Voronina T.P., Kashitsin V.P., Modchanova O.P. Education in the epoch VIT. ^ M .: AMO, 1995. 4. Abduqodirov A.A., Pardayev A.X. Theory and practice of distance learning. - T .: Fan, 2009.145 p. 


\title{
CHARACTERISTICS OF PATRIOTIC EDUCATION OF YOUNG PEOPLE
}

\author{
Karimova Gavkhar Qudratilla qizi \\ Tashkent State Pedagogical University named after Nizami, \\ Department of Social Pedagogy, etc. associate professors \\ Urakboyeva Ganjina Khairulla qizi, \\ Tashkent State Pedagogical University named after \\ Nizami "Faculty of Pedagogy and Psychology" 103 group students
}

\begin{abstract}
Annotation. This article reflects the views of our thinkers on how to increase the love for the motherland and the family in educating young people.

Keywords: Motherland, family, children, upbringing, love, place, friendship, hospitality, beauty, homeland.
\end{abstract}

Homeland! What is the homeland? Homeland is our mother, father, liver. It is a land where our umbilical cord blood was shed, a neighborhood, a place where our ancestors left traces, a place where we recognized our first love, a dear school. Because of the sense of homeland, a person loves the house he lives in, the neighborhood where he lives, the city and the village, he makes it prosperous, glorifies and protects its glory. The family is the foundation of our society. Patriotism is formed in the family.

The role of parents, community and teachers in the formation of a sense of patriotism in the heart of a child is invaluable. At the same time, increasing the responsibility of parents in instilling a sense of patriotism in young people is recognized as an urgent task.

In this sense, the great Alisher Navoi's words "If you are a man, you are a man, I have no grief for the people" have a deep life wisdom and philosophy. In other words, in this world, the highest criterion of humanity is to live for the people and the country, thinking about the sufferings of the people. Our great ancestor says that a person who thinks only of himself, who is far from the worries of the people, and whose personal interests take precedence over everything, cannot be considered a human being.

In his creative work, Muhammad Reza Oghahi called on young people to serve the people, the country and society. He praised friendship, hospitality and moral beauty. Encourages people to be smart and to speak the truth.

Throughout his career, Berdymurod Berdak, the People's Poet of Karakalpakstan, promotes the ideas of equality, humanity, patriotism and justice.

Resolution of the President of the Republic of Uzbekistan Sh. Mirziyoyev dated May 3, 2019 No PP-4307 "On additional measures to increase the effectiveness of spiritual and educational work" tasks such as improving the environment, focusing on the upbringing of children in the family, increasing parental responsibility in achieving sustainable development of society.

It is important to instill a sense of patriotism in a child from an early age. Do you really have to work at the border or in the military to be a patriot? If a person is a qualified specialist in his profession, if he benefits the society and the people with this activity, then he is a patriot. The value of the homeland is even more evident when it is far away. That is why our wise people say, "Be a beggar in your own country until you become a king in another country." These thoughts are reflected in the poem "Take Me" by the People's Poet of Uzbekistan Abdulla Aripov.

My homeland is Uzbekistan,

There is no way to tell the magic

No, in other countries, I can't give up!

Take me home.

I think it is not difficult to understand what happened in the heart of our master poet Abdulla Aripov when these words were written on paper. Patriotism is a great virtue. What really unites people? A noble goal, a dream, and most importantly a common good! The history, present and future of the country concern everyone. The feeling of homeland is more important than anything else.

As the First President of the Republic of Uzbekistan I.A. Karimov said, "We must all live and work for the children of one country, Uzbekistan - our homeland, and solve problems together. No one has the right to separate neighborhoods, villages, districts, or even provinces, to claim that My umbilical cord blood was spilled in such or such neighborhoods or villages. Now it is necessary to get 
rid of this disease. For us, the Motherland is one country."

In his speech at the solemn ceremony dedicated to the twenty-ninth anniversary of independence, President of the Republic of Uzbekistan Sh. Mirziyoyev said: "No matter what dangerous and turbulent times we go through, no matter what achievements and results we achieve, the idea of independence, the spirit of independence is always with us the basis for a living". Because we are the descendants of Manguberdi, Ulugbek and Tomaris. It is the sacred duty of each of us to be worthy successors to them ...

In conclusion, today we are an example for all young people. Our peers are an example to our peers of respect and honor for their parents, love, love for the Motherland, loyalty to the family and the country. We must always keep in mind the teachings of our great thinkers and scholars by reading the works they have left for us.

\section{References}

1. Karimova G.Q. The role of national and spiritual values in the process of education of youth. ACADEMICIA: An International Multidisciplinary Research Journal. ISSN: 2249-7137 Vol. 10, Issue 10, October 2020 Impact Factor: SJIF $2020=7.13,75-79$ p.

2. Karimova G.Q. Pedagogikaning asosiy masalalari. O‘quv-uslubiy qo'llanma. - T.: "Lesson Press" nashriyoti. 2020, 140 b.

3. https://lex.uz/ru/

4. https://www/sharq-mutafakkirlarining-farzand-tarbiyasi-haqidagi-fikrlari-2/ 
USE OF ELECTRONIC EDUCATION RESOURCES IN THE LEARNING PROCESS

\author{
Khasanov Abdushokhid Abdurashidovich - \\ Head of the Department of Information Technology, \\ Tashkent State Pedagogical University, PhD. Tashkent abdushohid_1983@mail.ru \\ Urokova Sharofat Bakhodir qizi \\ Teacher of the Department of Information Technology
}

\begin{abstract}
Annotation: This article outlines the problems and the causes of their occurrence in the development of means of information resources, including electronic educational resources (EER), ways to solve them, especially the preparation of teachers for use in EER training classes.

Key words: information technologies, electronic educational resources, professional competence, professional training, methodological system.
\end{abstract}

Today, it is difficult to imagine education without informatics, information and computer technologies. In particular, e-learning resources (EER), which greatly help teachers to achieve their work efficiency in the conduct of lessons, also serve to make lessons interesting, increase the educational and pedagogical achievements of students. Therefore, the issue of widespread and effective implementation of EER in the educational process today remains one of the most pressing issues in the professional training of teachers of computer science and information and communication technologies [1].

It should be noted that today it is difficult to express the opinion that EERs are always used in the work of teachers of computer science and information technology. According to research, EERs used in the teaching process are used in traditional teaching methods mainly for the purpose of "filling in the gaps". The pedagogical relevance of many developed and used EERs depends on the "conscience" of the authors of these programs, as many of these developments do not meet today's requirements for information of education, theoretical and conceptual developments in this area does not take into account the requirements of didactic methodology. That is why it is important to study the specifics of the development and preparation of teachers for e-learning resources.

Indeed, EERs are often used in the traditional teaching model in the form of lecture-instructions, which consist of slides, animated objects, and fragments of video material, in order to develop learners' interest in learning. This type of training is passive, although today the training of learners in the opposite way, that is, in an active nature, is on the agenda.

This situation with the use of EERs in teaching contradicts the views expressed in many psychological and pedagogical studies, which highlight the importance of EERs in improving learning outcomes [2]. Information technology has enormous potential to overcome such situations and increase the efficiency and productivity of ETRs. in particular, EER is able to shape the relationship between participants in the learning process based on mutual trust.

Among the identified shortcomings of the low efficiency of the use of EERs is the attempt to adapt EERs to the traditional learning environment, which includes the traditional goals, content, form and methods of teaching. It is important to emphasize the need to take full advantage of the potential and, in particular, the inability of teachers to properly formulate technical tasks in the development of EERs.

With this in mind, it is necessary to take into account the new educational goals in the development and implementation of EERs in the educational process. Today, such goals are designed to meet the demands of the individual, the family, society, and the state on the education system, given the growing potential of information technology. In order to achieve these goals, it is necessary to inform the public, including the education system, and to involve EERs in the educational process, which can incorporate the achievements of information technology.

As noted in almost all modern scientific research, the use of information technology tools (including EERs) at the level of teaching subjects and training of teachers who are able to solve current professional problems with their help. will be necessary. Particular attention will be paid to the creation of EERs that can meet the needs of modern education, with quality content and functionality appropriate to the individual learning systems of the subject, aimed at achieving the planned learning outcomes. As a result, the problem of creating appropriate professional qualities in teachers, as well as the creation of an information and educational environment in the modern education system will 
become a topical issue [3].

In general, it is a promising direction in the training of teachers of computer science, information and communication technologies, teaching not only the technical and technological aspects of working with information technology, but also the study of e-learning resources in the learning process. such as formulation, development, selection, and methodologically correct application.

In general, it is a promising direction in the training of teachers of computer science, information and communication technologies, teaching not only the technical and technological aspects of working with information technology, but also the study of e-learning resources in the learning process. such as formulation, development, selection, and methodologically correct application.

\section{List of used literature:}

1. Sharipov D., Abdukadirov A., Khasanov A. and Khafizov O., «Mathematical model for optimal siting of the industrial plants,» 2020 International Conference on Information Science and Communications Technologies (ICISCT), Tashkent, Uzbekistan, 2020, pp. 1-3, doi: 10.1109/ ICISCT50599.2020.9351476.

2. Hasanov A. A. Peculiarities of preparing teachers for the development and use of e-learning resources // International Scientific Journal Theoretical \& Applied Science № 9. (89). 2020. P.1517.

3. Xasanov A.A., Mirjamolova F.N. Access to electronic educational resources in the education system // European Journal of Research and Reflection in Educational Sciences Vol. 7 No. 12, 2019 ISSN 2056-5852 P. 442-445. 


\title{
ADAPTIVE LEARNING SYSTEM USING FUZZY LOGIC
}

\author{
Rasulova Nasibakhon Yusufjonovna \\ assistant of the Department of Information and Educational \\ Technologies of the Tashkent University of Information \\ Technologies named after Muhammad al-Khwarizmi. Uzbekistan
}

\begin{abstract}
: the article discusses the relevance and effectiveness of individualization of online learning using information and Internet technologies, the features of a multi-agent approach using fuzzy logic, an analysis of intelligent adaptive learning systems with different types is given, their models, advantages and disadvantages are also given.
\end{abstract}

Key words: adaptive learning, intelligent adaptive learning systems, online learning, online learning systems, platforms for online learning, online learning models.

Modern adaptive e-learning is currently actively developing in the field of education, relying on knowledge engineering methods used to create educational information systems, taking into account the behavior and state of knowledge of a person in the learning process .

The method of expert assessments, based on the use of expert information systems, makes it possible to realize the possibility of not pre-setting a sequence of learning steps, since it is built by the information system itself in the process of its functioning. This makes it possible to form for each student a primary individual training plan based on his competence- oriented model, which is based on the analysis of answers to questions from special tests, some of the student's personal characteristics. Expert training systems (ETS) are capable of performing structural and parametric adaptations, which make it possible to bring the structure and parameters of the student's model closer to his real "portrait", but the didactic possibilities presented in this case are very limited. The individual training plan is corrected by the ETS based on the results of mapping the student's current model, based on his learning experience, to the reference model of the course, followed by comparison with fragments of the applied ontology of the course or discipline.

In addition, a technology is being developed for the automated construction of integrated ETS, which simultaneously uses the approaches of both knowledge engineering and ontological engineering, intelligent planning and traditional programming [1].

Fuzzy logic and the theory of fuzzy sets for the first time about the limits of American scholar Lutfi Zade: "The more we analyze the real problem, the more uncertain it becomes a solution." The reason for the emergence of the theory of "fuzzy sets" was the presence of fuzzy reasoning in the description of processes, systems or objects by a person [2]. The human mind, unlike a machine, operates with fuzzy concepts when assessing various situations. Therefore, when making decisions, in conditions of inaccurate information and in the presence of fuzzy goals, the method of fuzzy sets is used.

A fuzzy set is a subset of elements A from E, such that each element is associated with the degree of membership of this element in the set E. The fuzzy set is completely determined by specifying the membership function $\mu \mathrm{A}(\mathrm{x})$ : its domain of definition is $\mathrm{E}$, the range of values is the segment $[0,1]$, where 0 means that the element is not included in the fuzzy set, and 1 describes a fully included element. Values between and indicate elements that are not clearly included. The higher the value of $\mu \mathrm{A}(\mathrm{x})$, the higher the degree of belonging of an element $\mathrm{x}$ from $\mathrm{E}$ to a fuzzy set $\mathrm{A}$ is estimated [2].

In this article it is considered a way to change the level of difficulty of the course with the use of fuzzy sets. The following fuzzy scale of changes in the level of complexity of the course is proposed: "Decrease", "Leave" and "Increase". At the same time, there can be any number of levels of complexity of the course. The change in the level of difficulty of the course for the student occurs step by step. In the first stage, all students start learning at minimum difficulty.

After the number of lessons set by the teacher has expired, an adaptive system for changing the difficulty is connected. Evaluation of the results occurs at the end of two lessons in a row. If the number of mistakes made is acceptable to increase the level of complexity, then the system transfers it to a more difficult level relative to the current one. When the number of errors more than a predetermined threshold, the system determines how to change the difficulty of the course the student - to lower or keep the current level. If the error rate is high for three lessons in a row 
at the lowest difficulty level, the system notifies the student's administrator or teacher.

In conclusion, it can be noted that the use of fuzzy logic in the development of systems for adapting educational content to a student is justified and has a number of the following advantages over steel options for implementation:

- there is no need to accumulate large statistical data to build an adaptation model, which are necessary for systems built using neural networks ;

- the curator can easily make a change in the logic of the system itself by changing the degree of belonging ;

- $\quad$ systems based on fuzzy logic can contain a large number of both input and output variables, which allows building educational content of any degree of complexity.

\section{References}

1. РасуЛова Н. Ю. АДАПТИВНОЕ ОБУЧЕНИЕ В СИСТЕМЕ ВЫСШЕГО ОБРАЗОВАНИЯ //Scientific progress. - 2021. - Т. 1. - №. 3.

2. Алтунина Н.А. Анализ системы адаптивного тестирования остаточных знаний обучающихся на базе нечеткой логики / Н.А. Алтунина, С.А. Ложкина // Вопросы науки и образования. -2017 . - № 4 . 


\title{
TECHNOLOGIES FOR THE DEVELOPMENT OF STUDENTS CREATIVE COMPETENCE IN PROFESSIONAL ACTIVITY
}

\author{
Rasulova Zilola Durdimurotovna \\ $\mathrm{PhD}$ Student Bukhara State University, \\ Bukhara, Uzbekistan \\ E-mail: zdrasulova@mail.ru
}

\begin{abstract}
Аннотация: This article is based on the concepts of creativity and competence. Based on the widespread application of interactive teaching methods and technologies in practice, the importance of further improving the pedagogical mechanisms for the development of creative competence in students is justified.
\end{abstract}

Keywords: creativity, competent approach, teaching methods, innovative educational technologies, professional activity.

Today, the issues of increasing the competitiveness of students on the basis of a competent approach to education, the creation of modern methodological support for designing the creative educational process through the development of creative competence of teachers, the development of students' creative skills, as well as increasing the social role of higher education. being investigated.

In this regard, it is important to modernize the content of modern education on the basis of advanced foreign experience, to create an innovative learning environment based on competencies, to further improve the pedagogical mechanisms for developing creative competence in students through the widespread application of interactive teaching methods and technologies.

The formation of a creative person can be defined as the development of a person in terms of creative activity and the creation of creative products that are performed in a mutually compatible way. The speed and scope of this process depends on biological and social factors, the activity and creative qualities of the individual, as well as the existing conditions, vital and professionally conditioned events. In modern conditions, it is necessary for a teacher to have creative qualities.

In order for students to fully understand the general essence of the process of developing the qualities of creativity, it is first necessary to understand the meaning of the concept of "creativity".

Creativity (Latin, "create" - to create, "creative" - creator, creator) - is the creative ability of the individual, which characterizes the readiness to produce new ideas and is part of the talent as an independent factor.

It is important to create a comfortable environment in the classroom before students develop creative thinking skills.

Students with creative thinking:

- expresses ideas that other students have not come up with;

- chooses a specific way of expressing themselves;

- sometimes asks irrelevant or unusual questions;

- enjoys tasks that remain open;

- prefers to discuss ideas on the basis of concrete evidence;

- chooses an unconventional approach to finding a solution to the problem.

Research shows that the social and economic needs of society depend on the high demands of creative thinking and creativity of the teacher of higher education, which is realized in the higher education system with the help of innovative educational technologies.

An important professional task of a teacher of higher education is to adapt to the innovations of the modern world, to prepare the younger generation for the life of a constantly renewed society and to develop the ability to actively participate in the process of improving it in line with modern requirements.

The Action Strategy identifies areas such as further improvement of the higher education system, increasing the capacity of quality education services, continuing the policy of training highly qualified personnel in accordance with the labor market, improving the quality and efficiency of higher education is of great importance.

Creating an innovative environment in the educational process creates an opportunity for students to develop creative skills on their own.

Under creative education is understood the organization of such creative activity, as a result of 
which it is possible to create new creative products for educational activities by subjects of educational activity, which is characterized by the originality of the solution, ie self-education and the ability to express creative quality.

The formation of the student's creative potential in the formation of professional competence depends on the correct organization of the educational process. Effective use of the creative potential of the listener in the formation of professional potential should be achieved through the proper organization of the educational process [1-3].

The structure and content of students' creative competence

\begin{tabular}{|l|l|l|}
\hline \multicolumn{1}{|c|}{ Type of activity } & \multicolumn{1}{c|}{ Competence } & \multicolumn{1}{c|}{ Competence structure } \\
\hline $\begin{array}{l}\text { The role of creativity in education } \\
\text { and in an informed society }\end{array}$ & $\begin{array}{l}\text { Innovative educational policy of } \\
\text { students and the role of creativity } \\
\text { in the development of the digital } \\
\text { economy of the state }\end{array}$ & $\begin{array}{l}\text { Introduces and discloses the } \\
\text { main normative documents in the } \\
\text { conduct of innovative education. } \\
\text { Represents the positive impact } \\
\text { of creativity on the quality of } \\
\text { education }\end{array}$ \\
\hline Professional development & $\begin{array}{l}\text { The student learns innovative } \\
\text { pedagogical practice on the basis } \\
\text { of modern technologies in the } \\
\text { development of creativity }\end{array}$ & $\begin{array}{l}\text { Identifies information resources } \\
\text { and their content used to develop } \\
\text { methodological knowledge and } \\
\text { skills in science on the basis of } \\
\text { creative teaching methods }\end{array}$ \\
\hline
\end{tabular}

An analysis of the above considerations shows that

1) provision of pedagogical conditions for the development of student creativity;

2) the use of different methods and technologies in teaching. One of the important professional qualities of educators is the pursuit of innovative pedagogical activity.

This innovative pedagogical rise sees new aspects of education and upbringing, based on evidence such as the creation of new pedagogical technologies based on non-traditionalism and originality, and most importantly, the creation of an optimal form of thinking, upbringing, actualization of understanding.

The conclusion is that the formation of the student's creative potential in the formation of professional competence depends on the correct organization of the educational process. Effective use of the creative potential of the listener in the formation of professional potential should be done through the proper organization of the educational process.

\section{References}

1. Rasulova Z.D. Pedagogical peculiarities of developing socio-perceptive competence in learners // European Journal of Research and Reflection in Educational Sciences. Vol. 8, No. 1, 2020, pp. 3034.

2. Rasulova Z.D. Conditions and opportunities of organizing independent creative works of students of the direction Technology in Higher Education // International Journal of Scientific and Technology Research. Vol 9, no. 3, 2020, pp. 2552-2155.

3. Kakhkhorov S.K., Rasulova Z.D. Methodology of improving the professional activity of the future teacher of technology on the basis of modern educational technologies // Universal J. of Educational Research. 8:12 (2020), pp. 7006-7014. 


\title{
РАХБАР ХОДИМЛАРНИ КОММУНИКАТИВ КОМПЕТЕНТЛИГИНИ РИВОЖЛАНТИРИШ ОМИЛИ
}

\author{
Байбаева Мухайё Худайбергеновна \\ Низомий номидаги Тошкент давлат педагогика университети \\ педагогика кафедраси доценти, педагогика фанлари номзоди
}

\begin{abstract}
Аннотация: Мақолада рахбар ходимларни коммуникатив компетентлигини ривожлантириш омиллари, ўзига хос жихатлари хусусида фикр-мулохазалар келтирилган.

Таянч сўзлар: компетенция, бошқарув, рахбар, қобилият, коммуникация, самарадорлик, ривожлантириш, фаолият.
\end{abstract}

Аннотация: В статье представлены факторы развития коммуникативной компетентности управленческого персонала, мнения об их специфических аспектах.

Базовые слова: компетентность, управление, лидер, способность, коммуникация, эффективность, развитие, активность.

Abstract: The article presents the factors of the development of the communicative competence of management personnel, opinions about their specific aspects.

Keywords: competence, management, leader, ability, communication, efficiency, development, activity.

Таълим тизимида рахбар ходимларни тармоқ ўзаро хамкорлик шароитида коммуникатив компетентлигини ривожлантиришни малака ошириш жараёнида таълим муассасаси ва бандликка кўмаклашиш марказларининг ўзаро интеграциясига асосланиб амалга ошириш, ўзаро хамкорликни ривожлантиришнинг ташкилий ва педагогик шарт- шароитларини ишлаб чиқишни талаб қилади.

Бугунги ижтимоий-иқтисодий шароит профессионал таълим битирувчисини барқарор иш билан таъминланишига кафолат бермайди. Бозор иқтисодиёти шароитида профессионал таълим битирувчиларини химоя қилиш учун мўлжалланган асосий механизмни уурганиш шуни кўрсатадики, профессионал таълим рахбар ходимларини малакасини ошириш жараёнида компетенциявий ёндашувга асосланган таълимни амалга ошириш зурурдир.

Фан-техника тараққиёти, янги технологиялар ва мехнат шароитлари иш сохасида сезиларли ўзгаришлар юз бермоқда, баъзи мутахассисликлар маънан эскирганлиги, бошқалари эса мазмунан сезиларли янгиланишни талаб қилади. Бундан ташқари илгари мавжуд бўлмаган янги касбларга бўлган талаб хам ортиб бормоқда. Бу холат профессионал таълим тизимига бўлган ўз талабларини, унинг янги касбларга қайта йўналтирилишинигина эмас, балки унинг мазмунини, технологияларини жадал ривожланаётган мехнат бозорига қаратилган ёндашувларини тубдан ўзгартиришни тақозо этади.

Ижтимоий ва саноат сохасида малакасиз мехнатга бўлган талаб пасайиб, бошқарув тизимларини автоматлаштириш ва компьютерлаштириш ортиб бормоқда ва янги кўникма ва малакаларга бўлган талаб ўзгарувчан иш шароитлари туфайли ортиб бормоқда. Бошқарувда инновацион фаолият олиб боришга қодир бўлган ва тизимли равишда интеллектуал, коммуникатив, рефлексив ва ўз ишини муваффақиятли ташкил эта оладиган профессионал таълим рахбарларини малакасини етарли даражада оширишни талаб қилади.

Таълим муассасаси рахбар ходимининг интеллектуал салохияти: ижодкорлик, ўзига хослик, танқидий фикрлаш, мустақиллик ва бошқалар каби таълимда кенг қабул қилинган қадрият йўналишидир.

Таълим муассасалари битирувчиларининг шахсий сифат ва фазилатларини ривожлантириш, касбий ўз-ўзини ривожлантириш ва хар қандай ишлаб чиқариш мухитига мослашувчанлик қобилиятини ривожлантиришга харакат қилади. Бандликка кўмаклашиш марказлари таълим муассасаси рахбарлари ва ишлаб чиқариш корхоналари билан узлуксиз хамкорлик олиб бориш орқали бўлажак кичик мутахассисларнинг тегишли малака талабларида келтирилган касбий фаолият турларига тайёргарлигини назорат қилиш, истиқболдаги режаларни хамкорликда белгилаши мумкин.

Таълим тизими анъанавий таркибий қисмларга эга: мақсад, вазифа, таълим мазмуни, шу жумладан метод, шакл ва воситалар, таълим субъектлари ва бошқалар. Бироқ, таълим тизими ижтимоий тартибни, иш сохасини ва ижтимоий-маданий мухитини хисобга олиши керак. 
Илмий, таълимий, инновацион, ижтимоий-маданий, саноат муассасалари ва корхоналар ва минтақанинг бошқарув тузилмалари, бандлик муносабатлари, ишлаб чиқариш, фан ва таълим сохаларининг интеграцияси ва жараёнлари билан бирлаштирилган мураккаб ижтимоий ва таълим тизимини иерархик равишда ўзаро боғлиқ компонентлар мажмуи билан қурилган мураккаб тизим деб аташ мумкин.

\section{Фойдаланган адабиётлар:}

1. Кудрявцева Е.И. Компетенция и менежмент: компетенции в менеджменте, компетенции менеджеров, менеджмент компетенции. Монография. Санкт Петербург.: 2012-340 с.

2. Агафонова И. Д. Формирование коммуникативной компетенции у менеджеров в дополнительном образовании : автореферат дисс. .... канд. пед. наук / И. Д. Агафонова. - Екатеринбург, 2009. $-27 \mathrm{c}$.

3. Акапьев В. Л. Модель формирования информационно-технологической компетентности преподавателей / В. Л. Акапьев // Альманах «Пространство и время». - 2012. - Том 1. - № 2. - C. $1-9$. 


\section{МАСОФАВИЙ МАЛАКА ОШИРИШ ТИЗИМИ ВА УНИНГ ТАРКИБИЙ КИСМЛАРИ}

Г.В.Елдашева

Ўзбекистон Республикаси, Тошкент шахар халқ таълими тизими кадрларини малакасини ошириш ва уларни қайта тайёрлаш худудий марказининг кафедра мудири, педагогика фанлари номзоди

Аннотация: мақолада масофавий малака ошириш тизими ва унинг элементлари мазмуни ёритиб берилган. Шу билан бирга, масофавий малака ошириш жараёни иштирокчиларининг вазифалари хамда масофавий таълимнинг характерли хусусиятлари келтирилган.

Калит сўзлар: малака ошириш, масофали таълим, масофавий малака ошириш тизими, масофавий малака ошириш таркибий қисмлари.

Мамлакатимизда замонавий ахборот-коммуникация технологияларининг ривожланиши таълим тизимида хам таълим олишнинг анъанавий шакллари ўрнига масофавий таълим элементларининг жадал кириб келишига замин яратди. Шунингдек, малака ошириш тизимига замонавий ахборот-коммуникацион технологияларнинг жадал суръатлар билан кириб келиши хамда доимо янгиланиб бориши мазкур тизимнинг ривожланишида ижобий ўзгаришларни юзага келтирмокда. Мана шундай ижобий ўзгаришлардан бири, малака оширувчиларга масофадан туриб таълим беришдир.

Масофавий малака ошириш тизими - масофавий малака ошириш шартлари асосида ташкил этиладиган ўқитиш тизими. Барча таълим тизимлари сингари масофавий малака ошириш тизими ўзининг таркибий қисмлари хисобланган мақсади, мазмуни, методлари, воситалари ва ташкилий шакллари, бахолаш механизмига эга. Масофавий малака ошириш мақсади - тингловчиларни иш жойидан ажралмаган холда Давлат талабларига мувофиқ равишда керакли сохалар бўйича мунтазам равишда билим, кўникма ва малакаларини такомиллаштириш хисобланади.

Масофавий малака ошириш мазмуни Давлат талабларидан келиб чиққан холда тингловчиларнинг малакасини ошириш жараёнини, уни жорий этишнинг ташкилий шакллари ва методларини белгилайди. Масофавий малака ошириш мазмунини танлашда малака оширишнинг ўқув-меъёрий хужжатлар бўйича талабларига, тингловчининг эхтиёжига, унинг тайёргарлик даражасига мувофиқ келишини инобатга олиш керак.

Масофавий малака ошириш жараёнида анъанавий малака ошириш каби ахборот-рецептив, репродуктив, муаммоли баён, эвристик ва тадқиқот методларидан фойдаланилади.

Масофавий малака ошириш шакллари анъанавий малака ошириш шаклларидан бирмунча фарқ қилади. Бундай шаклларга интерфаол онлайн машғулотлари, теле- ва видеоконференция, чат, интернет-конференция, электрон почта кабилар киради.

Масофавий малака ошириш воситаларига анъанавий босма воситалардан ташқари, компьютер технологиясини кўллашга асосланган тармоқ ўқув материаллари, компьютерли ўкув дастурлари, аудио- ва видеоматериаллар, виртуал тренажерлар, электрон кутубхоналар каби инновацион воситалардан фойдаланилади.

Масофавий таълимда таълим берувчи вазифасининг ўзига хослиги туфайли “тьютор” деб аталади. Тьютор - масофавий таълим курсини ўзлаштириш бўйича ўрганувчини кўллабқувватловчи маслахатчидир. Тьютор - маслахат берувчи, ўрганувчиларни кўллаб-қувватловчи таълим бериш субъекти хисобланади. Ўқув мақсадига эришишни таъминлаш учун тьютордан технологик, ташкилий, иқтисодий ва ижтимоий-психологик имкониятларни намоён эта олиш қобилияти талаб қилинади.

Тьюторнинг вазифалари куйидагилардан иборат:

- ўрганувчилар билан доимо мулоқотда бўлиш, ўрганувчилар билан “қайтар алоқа”ни ўрнатиш;

• урганувчиларнинг билим олиш кўникмаларини ривожлантиришда ёрдам бериш;

- ўрганувчининг муаммоларини тинглаш ва уларнинг ечимини топиш;

• у урганувчилар билан режа бўйича “юзма-юз” алоқа ўрнатиш;

- урганувчиларни бахолаш; 
- мулоқот ва тест натижаларини йиғиш;

- иш режасини тузиш, режа бўйича ишларнинг ўз вақтида бажарилишини таъминлаш.

Масофавий малака ошириш жараёнида таълим жараёнининг яна бир мухим таркибий қисми хисобланган бахолаш хам ўзига хос хусусиятларга эга. Масофавий малака ошириш ўз-ўзини назорат қилиш ва бахолашга йўналтирилган бўлсада, албатта тьютор томонидан хам назорат қилиб борилади. Масофавий малака оширишда бахолашнинг бошланғич, оралиқ ва якуний турларидан фойдаланилади. Бундай бахолаш турларида тест, амалий топшириқлар, ўзўзини назорат қилиш саволлари, лойиха ишлардан фойдаланилади.

Шунингдек, педагогларни масофавий таълим орқали малакасини ошириш оширишнинг қуйидаги мухим томонларини алохида қайд этиш мумкин:

- тингловчининг мустақил фаолиятига асосланганлиги;

- $\quad$ хохлаган вақт ва хохлаган жойда билимларни ўзлаштириш имкониятининг мавжудлиги;

- $\quad$ тингловчилар томонидан мустақил равишда орттирилган билим фаол характерга эга бўлишлиги;

- ўқитувчи ва бошқа тингловчилар билан доимий алоқада бўлиш учун имкониятнинг мавжудлиги;

- тингловчиларнинг олган билимларини бахолаш тизими тезкор қайтар алоқа асосига қурилган бўлиши;

- турли худудларда яшаётган турли ахоли қатламлари учун масофавий ўқишнинг мумкинлиги;

- ўқишнинг индивидуаллиги;

- педагог кадрларнинг малакасини ошириш тизимининг мослашувчанлиги;

- замонавий инновацион ва педагогик технологиялар билан ўзаро боғлиқлиги.

Масофавий таълим платформасида ўрганувчилар хар бир модулни мавзулар кесимида ўзлаштириб бориши, бунда мавзуни ўзлаштиришда уни тўлиқ кўриб чиқиши талаб этилиши, мавзуни якунламасдан кейинги мавзуга ўтиши бўйича чеклов ўрнатилганлиги ўз навбатида назоратнинг йўлга қўйилганлигининг ифодасидир.

Амалий машғулотларни олиб бориш учун учун MOODLE тизимининг ЧАТ ва ФОРУМ элементлари хамда семинар ўтказиш, топшириқ бериш ва уни жавобини текшириш механизмларидан фойдаланиш йўлга қўйиш эса машғулотнинг интерфаоллигини таъминлайди.

Айниқса бугунги кунда дунёда коронавирус пандемияси хукм сураётган бир даврда мамлакатимизда ўқув жараёнлари масофавий таълим платформаси хамда Zoom дастури орқали амалга ошириш, шунингдек Zoom орқали олиб борилаётган маърузалар ёзиб олиниб, youtube каналига ва ўрганувчиларнинг телеграмм ижтимоий тармоғидаги гурухларига юклаб бориш ижобий натижалар бермоқда.

\section{Фойдаланилган адабиётлар}

1. Жуманазаров С.С. Таълим жараёнида интеллектуал ўқитиш тизимлари// Таълим жараёнини сифатли ташкил этишда илғор педагогик технологияларнинг роли: Республика илмийамалий конференция материаллари.- Тошкент: ЎМКХТМ, 2008.- Б. 59.

2. Елдашева Г.В. Масофавий таълим орқали махсус фан ўқитувчилари малакасини оширишнинг ўкув-услубий таъминотини яратиш. Пед. фан. ном. дисс. ...-Т.: 2011.-146 б. 


\title{
РОЛЬ ИНФОРМАЦИОНОННЫХ ТЕХНОЛОГИЙ КАК СРЕДСТВА ИНОСТРАННЫМ ЯЗЫКАМ
}

\author{
Дилмурадова Нилуфар Асатуллаевна \\ Заведующий кафедрой Узбекский и русский языки \\ Ташкентский Финансовый Институт
}

\begin{abstract}
Аннотация: Эта статья описывает роль и значение информационных технологий в образование. А также обсуждаються такие вопросы как выбор материалов для языковых занятий и вопросы касающиеся эффективных информационно коммуникационных технологий .
\end{abstract}

В настоящее время в реализации общих стандартов образования активно осуществляется внедрение информационных и коммуникационных технологий в процесс обучения особенно в обучение иностранных языков. Все виды современных технологических средств обучения способствует модернизации учебно-воспитательного процесса, активизирует мыслительную деятельность учащихся, способствует развитию творчества педагогов, позволяют проводить дистанционное обучение, развивают систему непрерывного образования, тем самым повышая эффективность образовательного процесса. В сегодняшний день компьютеризация учебного процессарассматриваетсякакодинизактуальныхфактороворганизацииобучениятомуилииному предмету.Новейшие информационные технологии в обучении позволяют активнее использовать научный иобразовательныйпотенциал ведущих университетов иинститутов, привлекатьлучших преподавателей к созданию курсов дистанционного обучения, расширять аудиторию обучаемых.

Использование ИКТ в области образования практически безгранично. Наличие компьютера, подключенного к Интернету, способствует значительной проработке любой темы. Систематическое изучение различных дисциплин невозможно без наглядных средств обучения. До сих пор самым распространенным средством для визуализации новой информации являлись (часто и сейчас в большинстве своем являются) доска и мел, плакаты и карты, различные дидактические рисунки. Компьютер же, особенно подключенный к сети Интернет, соединяет различные виды наглядных пособий, позволяет обновлять дидактические материалы, а также оптимизировать и разнообразить учебный процесс. Базовое овладение навыками обращения с электронной почтой, поиска информации в Интернете, используя различные поисковые машины, умением использовать программы для онлайн-общения, грамотное использование элементов Web-проектирования и Webдизайна необходимы не только студенту, но и в первую очередь преподавателю. Для этого ему следует постоянно повышать свой уровень компьютерной грамотности и ориентированности в Интернет-пространстве, всегда находясь на шаг впереди учащихся. Но здесь следует выразить твердую уверенность в том, что компьютер даже на современном этапе развития технологий не должен и не может брать на себя функции преподавателя. По нашему мнению, правильная организация профессиональной подготовки специалиста в вузе предполагает использование информационно-коммуникационных технологий в качестве лишь вспомогательного средства обучения, обеспечивающего как оптимизацию процесса познания, так и формирование индивидуального стиля профессиональной деятельности. При этом, как уже отмечалось выше, роль преподавателя в условиях использования информационно-коммуникационных технологий остается не только ведущей, но и еще более усложняется. Он подбирает учебный материал, разрабатывает структуры и алгоритмы взаимодействия обучаемых с компьютерными средствами обучения, формирует критерии управления действиями обучаемых и т.д. Преподаватели вузов в современных условиях ищут и применяют на практике новые методы, используя информационные технологии в обучении иностранным языкам. Всѐ чаще при подготовке и проведении занятий преподаватели иностранных языков используют образовательные и справочные интернетсайты, программы текстового, голосового и видео-общения (e-mail,Skype,Telegram,Viber), составляют различные задания для самостоятельной работы студентов по поиску дополнительной информации по пройденным темам в Интернете. Так, например, информационные образовательные ресурсы, используемые в учебном процессе, позволяют представить обучающие материалы по иностранному языку в текстовом и гипертекстовом, а также графическом, аудио-, и видео- форматах, автоматизировать систему контроля 
и оценки знаний студентов, повысить интерес к изучению языка, более эффективно организовать самостоятельную работу. Ведение переписки в специальных сервисах, а также по электронной почте создает благотворную среду для применения иностранного языка в повседневной жизни, дает возможность применять и закреплять полученные языковые знания в ситуациях реального общения в письменной речи, а также, что немаловажно, ускоряет овладение межкультурной компетенцией. Применение компьютерных презентаций в учебном процессе позволяет ускорить и облегчить усвоение нового материала. Визуальная насыщенность и наглядность учебного материала способствуют более полному пониманию и раскрытию различных тем, например при изучении со студентами лингвострановедческого компонента обучения иностранному языку.

Компьютерные презентации акцентируют внимание студентов на значимых моментах информации. Использование презентации позволяет повысить мотивацию студентов, например, через использование большого количества иллюстраций, мультимедиа, привлечения Интернет-источников как источников информации о стране изучаемого языка и дополнительного источника информации. Всѐ это служит более глубокому вовлечению студентов в самостоятельный процесс обучения. Студентам вуза все чаще предлагается подготовка докладов в форме компьютерных презентаций для их выступления перед группой на занятии с последующим коллективным обсуждением. Также одним из основополагающих условий эффективного применения информационно-коммуникационных технологий является личная заинтересованность педагога в ее использовании. Это означает, что преподаватель должен убедиться на собственном опыте, как данная технология помогает ему более эффективно решать некоторые педагогические и дидактические задачи обучения (например, раскрыть значимость изучаемого учебного материала, повысить интенсивность его усвоения, развить и закрепить навыки практической работы, управлять учебной деятельностью и т.д.). Деятельность преподавателя в условиях применения информационнокоммуникационных технологий неизмеримо усложняется. Это связано с тем, что педагог осуществляет ее в новой педагогической среде и с новыми средствами обучения. Он получает возможность оказывать воздействие на обучаемых опосредованно через Интернет. В этих условиях преподавателю приходится реализовывать ряд функций, которые при традиционном обучении отсутствуют. Из вышеизложенного следует, что компьютерная культура преподавателя выступает решающим условием успешного использования информационно-коммуникационных технологий. Таким образом, одним из важных факторов совершенствования системы подготовки профессиональных кадров в высшей школе является активное использование в образовательном процессе современных ИКТ.

\section{Список литературы}

1. Сергеева М.Э. Новые информационные технологии в обучении английскому языку // Педагог. - 2005. - № 2. - С.162-166

2. http://www.de.vlsu.ru/distantsionnoe_obuchenie/publikatsii/?eid=531 


\section{БЎЛАЖАК ЎКИТУВЧИЛАР ЖАМОАСИДАГИ ЎЗАРО МУНОСАБАТЛАРНИ РИВОЖЛАНТИРИШГА ТАЪСИР ЭТУВЧИ ОМИЛЛАР}

Мирзаева Фарохат Одилжоновна Низомий номидаги Тошкент Давлат педагогика университети "Умумий педагогика" кафедраси доценти Педагогикава психология мутахассислиги 1-курс магистранти Бойманова Мухлиса

Ушбу мақолада шахслараро муносабат маданиятни ривожлантириш омиллари, педагогик мулоқотдаги ижодийлик омиллари, педагогика олий таълим муассасаси талабалар жамоасидаги шахслараро муносабатларнинг ўзига хосликлари ва бўлажак ўқитувчиларни тайёрлаш билан ўзаро алоқадорлиги талабаларнинг ўзаро муносабатларини мақсадга йўналтирилган тарзда ривожлантиришга доир маълумотлар келтирилган.

Калит сўзлар: бўлажак ўқитувчи, мулоқот, шахс, муносабат, тарбия, қобилият, фаолият, маданият, бахолаш, хусусият.

Ключевые слова: будущий учитель, встреча, личность, отношение, воспитание, способность, деятельность, культура, аутент, оценивать, особенность.

Key words: future teacher, negotiations, person, reiation, education, ability, activity,culture, authentication, to estimate, quality.

Бугунги кунда таълим жараёнини бошқаришда мулоқотнинг ахамияти катта бўлиб, у бир неча босқичларга бўлинади. Бу бевосита таълим муассасаси рахбарининг ўз қўл остидагилари, олий таълим муассасаларда кафедра мудири ва профессор-ўқитувчилар, профессорўқитувчилар ва талабалар ўртасидаги мулоқотдир. Буларнинг барчасини умумлаштирган холда таълим бошқарувидаги педагогик мулоқотга киритиш мумкин. Педагогик мулоқотпедагогик таъсирнинг ажралмас сифатидир. Бу ўқитувчи ва ўқувчининг таълим-тарбия жараёнидаги профессионал мулоқоти бўлиб, унда маълумот алмашинади ва ўқувчиларга ўкувтарбиявий таъсир ўтказилади. Бунда икки ёқлама мулоқот юзага келиши лозим. Унинг асоси сифатида ўзаро хурмат ва ишонч хизмат қилади. Педагог педагог билан мулоқотга киришиш жараёнида бир биридан хурмат кутади. Бу педагогик таъсирнинг самарали йўли бўлиб, тажрибали педагоглар бир бирини ўзаро хурматлашга асосланган холда муносабатларни ташкил этадилар ва шу орқали ўзаро муносабатларни амалга оширадилар. Мулоқотнинг ўзига хос 3 та даражалари мавжуд. Булар: макро даражада (катта)-ёшдаги педагоглар билан мулоқот қилиш барча одоб-ахлоқ нормаларига суянган холда амалга оширилади. Мезо даражада(ўрта)ёшдаги педагог билан мулоқот маълум мавзу асосида кечади. Микро даража (кичик)-ёшдаги педагог-ходимлар билан мулоқотнинг оддий шакллари, савол-жавоб тариқасида юз беради. Мулоқотнинг турлари: шахслараро (инсон-инсон), шахсий-гурухий (гурух-гурух), оммавий коммуникация (радио, телевидение, рўзномалар ва журналлар) каби турлари мавжуд.

Мулоқот жараёнини ва мулоқотсиз ўзаро таъсир жараёнларини тўғри ташкил этиш билан бир қаторда, таълим муассасаси рахбарлари ўқитувчиларнинг фаолиятини тўғри бахолай билишлари хам зарур хисобланади. Таълим муассасаси рахбари томонидан ёш ўқитувчи фаолиятининг эътироф этилиши, турли тадбирларда илғор тажрибага эга бўлган ўқитувчилар қатори, фаол ёш ўқитувчиларни хам мукофотлаб, рағбатлантириб бориши ўқитувчиларнинг касбий компетентлилигини ривожлантиришда ўзига хос ахамият касб этади.

Бевосита таъсир вужудга келувчи мулоқот жараёнида ихтиёрий иштирокчининг, яъни сухбат жараёнидаги ўқитувчи ёки устоз ўқитувчининг фикри, ғояси, сухбат мавзуси йўналишидаги тушунчалари, унинг сўзлаш динамикаси, нутқи хамда унинг юзидаги табассум, самимийлик ва жўшқинлик, ўз сухбатдошига қараб туриши ва уни тинглай билиши, сухбатдоши учун хам ўз фикрларини билдириши ва самимий сухбатлашиши учун имкониятлар яратиши мазкур жараён иштирокчиларида сухбатлашилаётган мавзуга нисбатан қизиқиш шакллантириши билан бир қаторда, уларда мухим ахамиятга эга бўлган шахсий сифатларни шакллантиришга хизмат қилади. Уқитувчилар ва устоз ўқитувчилар маълум бир белгиланган муносабатда бўлсалар-да, ўқитувчилар ва устоз ўқитувчиларнинг ўз функционал вазифалари бўлиб, мазкур функционал вазифаларни, яъни ўқиш ва ўқитиш, ўргатиш ва ўрганиш каби функционал вазифаларни 
амалга ошириш жараёнида доимий жонли мулоқотда бўлавермайди, шунга қарамасдан, барча ўқитувчилар ўртасида хамда устоз ўқитувчилар билан ўқитувчилар ўртасида хам бевосита ўзаро таъсир мавжудлиги тарбиявий муносабатларда намоён бўлади.

Бўлажак ўқитувчилар жамоасидаги шахслараро муносабатлар тузилмасини тавсифлашда муносабатлар динамикаси, ўзаро муносабатларнинг модаллиги, бўлажак ўқитувчиларнинг психологик яқинлик даражаси каби параметрлар алохида-алохида кўриб чиқилди.

Тадқиқот натижалари педагогика олий таълим муассасаси талабалари жамоасидаги шахслараро муносабатларга хос қатор ўзига хосликларни аниқлаш имконини берди: шахслараро муносабат ёшлик даврида етакчи ўрин тутувчи мулоқотга эхтиёж асосида юзага келади; бўлажак ўқитувчини жамоадаги шахслараро муносабатлар тизимига жалб этиш олий таълим муассасасига муваффақиятли мослашувини белгилаб беради; шахслараро муносабатлар тизимида бўлажак ўқитувчиларнинг холати ва унинг академик ўзлаштириш ўртасида ўзаро алоқадорлик мавжуд; талабалар жамоасидаги шахслараро муносабатларнинг табиий ривожланиш динамикаси бўлажак ўқитувчиларни тайёрлаш жараёни сифатини пасайтиради.

Мазкур йўналишдаги педагогик фаолият бўлажак ўқитувчилар жамоасига таъсир кўрсатувчи омилларга таянилган холда самарали амалга оширилиши мумкин. Бўлажак ўқитувчилар жамоасидаги шахслараро муносабатларни ривожлантиришга таъсир кўрсатувчи омиллар қаторига унинг хаётий фаолияти ва бўлажак ўқитувчининг муваффақиятли тайёрлаш шарт-шароитлари билан боғлиқ. Бундай омиллар қаторига биз талабалар жамоасидаги лидер позицияси, талабалар жамоасидаги гурухий меъёрлар, ижтимоий-психологик мухит, талабалар жамоасининг уюшганлиги, талабаларнинг маълум бир социометрик тоифага мансублиги ва бўлажак ўқитувчини тарбиялашга хизмат қилувчи мухитда намоён бўладиган бошқа омилларни киритдик. Бўлажак ўқитувчилар жамоасидаги ўзаро муносабатларни ривожлантиришга таъсир этувчи омиллар уларнинг умумий хусусиятларини аниқлаштириш натижасида педагогик фаолиятнинг илмий асосланган стратегияси ва тактикасини ишлаб чиқишга имкон берди. Бундай ишларнинг ахамияти шубхасиз, шахс, бўлажак ўқитувчи тарбияланаётган жамоа мазкур гурух ва жамият ўртасида боғловчи бўғин вазифасини бажаради. Шахслараро муносабатлар маданиятини ривожлантиришнинг ички ва ташқи омилларини ажратиб кўрсатиш имконини берди. Ташқи омилларга ижтимоий, ичкисига эса, психологик омиллар киритилди. Ижтимоий омиллар сифатида куйидагилар белгиланди: референт гурухлар; оила; таълим жараёни. Психологик омилларга субъектнинг шахсий сифатлари, айнан: мотивацион-қадриятга йўналтирилганлик, эмпатия ва рефлексияга қобилиятлилик киритилди. Талабаларда шахслараро муносабатлар маданиятининг ривожланишига педагогик таълим мазмунини аксиологик, бўлажак ўқитувчи фаолияти билан боғлиқ ижтимоий ахамиятга эга мазмун билан бойитиш, эмоционал, диалогик мулоқотга асосланган хамкорликдаги ўқув фаолиятини ташкил этиш, ўзаро биргаликдаги фаолият иштирокчиларининг жипслаштирувчи шахслараро муносабатни ривожлантиришга йўналтириш орқали эришиш мумкин. 


\title{
ПУТИ ПОВЫШЕНИЯ ЭФФЕКТИВНОСТИ ПРЕПОДАВАНИЯ СПЕЦИАЛЬНЫХ дИСЦИПЛИН
}

\author{
Муминова Дилнавоз Комиловна, \\ Сайфуллаева Дилафрўз Ахмадовна \\ mdilnavoz@internet.ru \\ Sayfullayeva86@inbox.ru
}

\begin{abstract}
Аннотация: Данный тезис определяет качество подготовки квалифицированных специалистов в образовательных учреждениях профессионального образования, во многом эффективное преподавание специальных дисциплин. Выбор методов обучения по специальным предметам и постановка образовательных целей также требуют специфики.

Ключевые слова: методы деятельности, профессионально-педагогические, профессионально-технические, ремесленные.

Annotation: This thesis determines the quality of training of qualified specialists in educational institutions of vocational education, in many respects the effective teaching of special disciplines. The choice of teaching methods in special subjects and the setting of educational goals also require specifics. The leading component of the special sciences is "methods of activity".
\end{abstract}

Keywords: methods of activity, professional pedtechnical, professional technical, crafting.

Ведущим компонентом специальных наук являются «методы деятельности».

В настоящее время одной из актуальных задач, стоящих перед системой образования профессиональных учебных заведений, является широкое использование инновационных технологий и достижений в преподавании, внедрение их в учебный процесс, а также внедрение опыта развитых стран в систему образования нашей страны.

Качество подготовки квалифицированных специалистов в образовательных учреждениях профессионального образования во многом определяет эффективность преподавания специальных дисциплин. Тот факт, что чем выше практичность при изучении специальных предметов, тем ближе они рассматриваются к производству, свидетельствует о том, что они отличаются от общеобразовательных предметов. Производственные операции осуществляются в связи со специальными науками. Выбор методов обучения по специальным предметам и постановка образовательных целей также требуют специфики. Ведущим компонентом специальных дисциплин является «методика деятельности». Поэтому необходимо проводить углубленный дидактический анализ в создании учебной литературы по специальным предметам и определении содержания образования, связанного с ней, в организации учебного процесса, в выборе эффективных методов обучения.

Специальные дисциплины охватывают процессы, дающие непосредственные глубокие, доскональные знания, отражающие особенности конкретной специальности в конкретных областях производства, формирующие соответствующие навыки и квалификации.

В предложении к таким субъектам относятся субъекты, непосредственно демонстрирующие особенности видов деятельности в различных сферах народного хозяйства: сельскохозяйственные отрасли, предприятия промышленного производства, машиностроение, транспорт, связь, отрасли народных промыслов, направления культуры и искусства и другие сферы, их составляющие.

Содержание специальных наук должно соответствовать описанию того или иного направления или специальности, то есть охватывать методы деятельности, выполняемые той профессией, которую занимает педагог. Для формулирования профессионально политехнических и профессионально - технических понятий в образовании реципиенты должны придерживаться политехнического принципа при определении содержания специальной науки. Профессиональные политехнические понятия включают в себя: структуры оборудования и техники в конкретной области производства, основы эксплуатации и их проектирования, технологии производства, автоматизацию технологических процессов, научные основы организации профессиональной деятельности, экономические факторы трудовой деятельности в данной области. Если педагогу необходимо изучить типы машин и оборудования многих типов, основы их расчета, проектирования, ремонта или технологических процессов в специальной науке, то в учебном материале должны быть даны конструкции 
моделей машин и оборудования в полевых условиях, режим работы или типовые схемы выполнения существующих технологических процессов, с тем чтобы в учебном материале были приведены конструкции моделей машин и оборудования в полевых условиях.

Исследования показывают, что люди могут учиться лучше и легче в спокойной, социальной обстановке Отдыха. В предложение все входит не только позитивная эмоциональная и социальная среда, но и целенаправленно оборудованная, наличие возможности быть активным. Чтобы максимально сфокусировать учебный процесс на студентах, предмет исследования должен быть соотнесен с потребностями студентов. Если студент информирован о результатах своей учебы для того, чтобы быть заинтересованным в учебе, и адаптирован к своим личным целям, то интерес к ним возрастет. В том случае, если студент активно занимается изучаемым предметом, процесс обучения будет развиваться, потому что у него будут первичные и вторичные мотивации.

Произнесение слов похвалы и признания, соответствующих результатам, достигнутым учеником в овладении, положительно влияет на возбуждение его интереса. Такая ситуация повышает их уверенность в собственных силах и уровень предъявляемых к ним требований. В процессе преподавания специальных дисциплин могут возникать различные сложные ситуации. Например, могут быть недостаточные начальные знания студента, отсутствие интереса, сложность решения задач или сложность задания. Эти трудности могут быть преодолены с помощью вспомогательных методов обучения, направленных на достижение образовательной цели.

К ним относятся:

-помощь в преодолении трудностей в обучении;

-поддержка поиска решений;

-поддержка производительности и внедрения;

-поддержка повторений и упражнений;

-помощь, направленная на предоставление освоенных знаний и применение их в новых ситуациях.

Чем лучше структурирована структура учебного материала и чем больше в нем законов, тем лучше запоминаются знания.

На основе проведенных теоретических и практических исследований можно сделать следующие выводы об эффективном изучении специальных дисциплин.

-Обучение должно проводиться маленькими шагами, т.е. шаг за шагом, и всегда должно основываться на базовых знаниях.

-Кроме того, следует поощрять обучение, например, успешное обучение с признанием и поощрением к его продолжению (посредством похвалы).

-Если студенты будут осведомлены о своих академических достижениях, интерес возрастет.

-Студенты учатся по принципу «независимого активизма», необходимо организовывать активные периоды обучения.

-Использование множества благоприятных условий в период обучения должно изменить учебную ситуацию.

-Если студенты много учатся активно, они будут продолжать осваивать и добьются успеха. Необходимо использовать активирующие методы обучения и проводить групповое обучение.

-Возможно повысить эффективность обучения за счет использования вспомогательных методов в процессе обучения.

Итак, будущий учитель ПТУ должен знать вышеперечисленные понятия. 


\title{
РАЗВИТИЕ ИНФОРМАЦИОННЫХ КОМПЕТЕНЦИЙ У БУДУЩИХ УЧИТЕЛЕЙ.
}

\author{
Муратов Эльвин Ильич \\ преподаватель Ташкентского государственного \\ педагогического университета им. Низами \\ muratov.elwin@yandex.ru
}

\begin{abstract}
Аннотация. В статье рассматриваются некоторые вопросы развития Информационных компетенций у будущих учителей на примере Ташкентского государственного педагогического университета (ТГПУ), обсуждаются проблемы подготовки современных учителей с учетом реализации «Программы стратегического развития ТГПУ» в контексте изменения отношения общества к педагогической деятельности в Республики Узбекистан.
\end{abstract}

Annotatsiya. Maqolada Toshkent davlat pedagogika universiteti (TDPU) bo'lajak o'qituvchilarining Axborot kompetensiyalarini rivojlantirishning ayrim masalalari muhokama qilinadi, O'zbekiston Respublikasida jamiyatning pedagogik faoliyatga bo'lgan munosabatini o'zgartirish kontekstida hamda «TDPUning strategik rivojlanish dasturi» ning amalga oshirilishini hisobga olgan holda zamonaviy o'qituvchilarni tayyorlash muammolari muhokama qilinadi.

Tayanch so'zlar: raqamli avlod, rivojlanish, axborot kompetensiyalari, talabalar, o'qituvchi.

Ключевые слова: цифровое поколение, развитие, информационные компетенции, студенты, учитель.

Annotation. The article discusses some issues of the development of Information competencies in future teachers on the example of the Tashkent State Pedagogical University (TSPU), discusses the problems of training modern teachers, taking into account the implementation of the "Strategic Development Program of TSPU" in the context of changing the attitude of society towards teaching in the Republic of Uzbekistan.

Key words: digital generation, development, information competencies, students, teacher.

Значимость повышения развития информационных компетенций современных учителей определяется не только естественной социальной потребностью в высококвалифицированных кадрах для системы образования. По данным центра по изучению общественного мнения «Ижтимоий фикр», большинство опрошенных учителей Республики Узбекистан. отметили тревожные показателями оценки качества современных учебников, степень соответствия учебно-методическим требованиям, а также проблемы, связанные с разработкой и подготовкой учебников и учебных пособий к изданию.

Вследствие чего учителя общеобразовательных школ поддерживают реформы, направленные на поэтапное внедрение принципов индивидуализации учебно-воспитательного процесса и совершенствование методики преподаванияю [1]

Современные исследователи выделяют различные факторы, обусловившие увеличение количества проблем, в том числе относительно низкий уровень сформированной инновационной компетентности у педагогов в условиях меняющего общества, которое требует постоянных и адекватных переменам нововведений.[2]

Отмечается также и влияние многочисленных управленческих решений на расширение неопределенности и стохастичности высшего образования; доминирование позитивистских и сциентистских установок в отечественном педагогическом мышлении.[3]

Под интерактивными компьютерными технологиями будем понимать комплекс инновационных средств организации эффективного диалога для достижения желаемого результата, способствующий приобретению будущими учителями субъектного опыта в процессе информационного обмена и работы с сервисами сети Интернет. [4]

Одним из недостатков интерактивных компьютерных технологий и их применения в образовательномпроцессеявляется их односторонняя направленность, а именно направленность на осуществление самостоятельной деятельности, самообучение, саморазвитие, но они не затрагивают развитие умения обмениваться субъектным опытом и взаимодействовать в группах.[5]

Период перехода к цифровой экономике требует от системы образования новейших подходов и средств их реализации. Будущие учителя должны обладать не только профессиональными компетенциями, но и информационными компетенциями для эффективной профессиональной 
деятельности. В связи с этим и выбор средств формирования и развития информационных компетенций требует тщательности и апробации. Поэтому отбор средств формирования и развития информационных компетенции предусматривает определенные средства для организации практической аудиторной, самостоятельной и внеаудиторной работы у будущих учителей на каждой ступени образования в вузе.

\section{Список используемой литературы}

1. Республиканский Центр Изучения Общественного Мнения «Ижтимоий фикр» [Электронный ресурс] Учителя об учебниках: мнения, проблемы, решения , 2020 -. - Режим доступа https://ijtimoiyfikr.uz свободный. - Загл. с экрана

2. План основных мероприятий по реализации Программы стратегического развития ФГБОУ ВО «НГПУ» на 2016/2017 учебный год / сост.: А.Д. Герасев, Н.В. Алтыникова, Н.А. Ряписов, Б.О. Майер, Н.Н. Киселев, О.Г. Хмелев. - Новосибирск: Изд-во НГПУ, 2016.

3. Артамонова Е.И. Подготовка учителя к инновационной деятельности в современном вузе / Е.И Артамонова.// Педагогическое образование и наука. - 2016. - № 6. - С. 86-97.

4. Табачук Н.П. Комплекс интерактивных компьютерных технологий в развитии информационной компетенции личности студента/Н.П. Табачук// Социальные-педагогические технологии в социализации будущего профессионала. - 2018 - С. 79-82.

5. Лапчик М. Подготовка педагогических кадров в условиях информатизации образования : учеб. пособие/М. П. Лапчик.-М.:БИНОМ,2013.-182 с. - Режим доступа: http:/prof.notoproject. org/ courses/formirovanie-informacionnoj-kompetentnostipedagoga-v-oblasti-razrabotki-cifrovyhobrazovatelnyhresursov/ 


\section{ЎЗБЕКИСТОНДА ОИЛАЛАРНИНГ БАХТЛИЛИК ИНДЕКСИНИ БЕЛГИЛАШ: ХОРИЖИЙ ТАЖРИБА}

Нодира Мелибоевна Эгамбердиева

профессор, педагогика фанлари доктори

Махалла ва оилани кўллаб кувватлаш вазирлиги хузуридаги

"Махалла ва оила" илмий тадқиқот институти директори

Хуршида Ходжиакбаровна Сайдивалиева юридик фанлари бўйича фалсафа доктори (PhD)

Махалла ва оилани кўллаб қувватлаш вазирлиги хузуридаги "Махалла ва оила" илмий тадқиқот институти катта илмий ходими akbarova1982@inbox.ru $+998903286185$

Нодира Мелибоевна Эгамбердиева профессор, доктор педагогических наук Директор Научно-исследовательского института «Махалли и семьи» при Министерстве по поддержке махалли и семьи Республики Узбекистан

Хуршида Ходжиакбаровна Сайдивалиева доктор философии по юридическим наукам (PhD) старший научный сотрудник Научно-исследовательского института «Махалли и семьи» при Министерстве по поддержке махалли и семьи Республики Узбекистан

Nodira Melibaevna Egamberdieva Professor, Doctor of Pedagogical Sciences Director of the Scientific Research Institute "Makhalla and family" under the Ministry of the Support of Makhalla and Family of the Republic of Uzbekistan

Khurshida Khodjiakbarovna Saydivalieva Doctor of Philosophy in Law (PhD) Senior Researcher at the Scientific Research Institute "Makhalla and family" under the Ministry of the Support of Makhalla and Family of the Republic of Uzbekistan

Аннотация: Мақолада бахт тушунчасининг илмий назарий жихатининг амалий микдорий кўрсаткичларга айланиб бораётганлиги, бахт тушунчаси билан боғлиқ янги ёндашувларнинг юзага келаётганлиги, сиёсат ва давлат бошқарувида хам мазкур тушунчанинг микдорий жихатларини аниқлаган холда жамиятда мавжуд муаммоларни бартараф этиш, давлат органларининг самарали фаолиятини назорат қилишда фойдаланилаётганлиги, Халқаро Бахтлилик индексининг мақсади ва индикаторлари тахлили, хорижий давлатларда бахтлилик индикаторларини жорий қилган холда махсус давлат органларининг фаолият олиб бораётганлиги хамда мазкур жараёнда юзага келаётган муаммолар ва таклифлар келтирилган.

Аннотация: В статье анализируется переход понятия счастья с научно-теоретического аспекта абстрактном виде в количественный показатель, новые подходы в политике и управлении связанные с понятием счастья, также выявляются количественные аспекты этого понятия, устраняются существующие в обществе проблемы, пользование государственных органов для контроля их эффективной деятельности, цель международного индекса счастья и его индикаторы, а также приводиться зарубежный опыт деятельности специальных государственных органов счастья, а также проблемы и предложения, возникающие в этом процессе.

Annotation: The article analyzes the transition of the concept of happiness from a scientific and theoretical aspect in an abstract form to a quantitative indicator, new approaches in politics and management related to the concept of happiness, also identifies the quantitative aspects of this concept, eliminates existing problems in society, the use of state bodies to monitor their effective activities, the purpose of the international happiness index and its indicators, and also provides foreign experience 
of the activities of special state bodies of happiness, as well as problems and proposals that arise in this process.

Калит сўзлар: бахт, бахтлилик индекси, фаровонлик, давлат бошқаруви, жамият, ахоли, оила, рейтинг, индикаторлар, бахтни ўлчаш, бахтга эришиш, ислохотлар.

Ключевые слова: счастье, индекс счастья, благополучие, государственное управление, общество, население, семья, рейтинг, индикаторы, измерение счастья, достижение счастья, реформы.

Keywords: happiness, happiness index, well-being, public administration, society, population, family, rating, indicators, measuring happiness, achieving happiness, reforms.

Маълумки, “бахт”, “бахтга эришиш” ва “бахтли бўлиш” каби тушунчалар фалсафий категория хисобланади. Бахт тушунчаси билан боғлиқ кўплаб Ғарб ва Шарқ файласуф, шоир, ёзувчи, давлат арбобларининг афоризмларини кундалик хаётимизда хам учратиб турамиз. Бахт тушунчасига илмий нуқтаи назардан ёндашиш ўзининг узоқ тарихига эга эканлиги аниқ. Хозирда уни тадқиқ этиб келаётган фан намоёндаларининг кўлами хам ошиб бормокда, жумладан, бахтни психология, социология, сиёсатшунослик, иқтисодиёт хамда сўнгги йилларда юриспруденция соха вакиллари хам ўрганиб келмокдалар. Бугунги кунга келиб, бахт тушунчаси биз уйлаб фараз қилган мавхум назарий тушунчадан секин аста амалий характерга эга бўлиб бормоқда. Замонавий технологиялар асрида бахт тушунчаси ва унга бўлган интилишнинг қай даражадалиги, бахтнинг субъектив ва объектив характердалиги, бахтли бўлиш хуқуқи, оилавий бахт, бахтли шахар, бахтли давлат, бахт менежери лавозими, тавлимда бахт, бахтлилик индекси каби тушунчаларнинг юзага келганлиги шулар жумласидандир. Хатто бахтни ўлчаб, унинг асосида давлат бошқаруви ва сиёсатини белгилаш таклифлари хамда бу амалиётни ўзида жорий қилиб, муайян ютуқларга эга бўлишга улгурган давлатлар хам бор. Бу даражадаги қизиқиш ва эътиборнинг албатта ўзига хос сабаблари мавжудки, бу борада тадқиқот ўтказиш, ижобий амалиёт билан танишиш долзарб ахамиятга эгадир.

1970 йиллардан бошлаб халқаро ташкилотлар томонидан бахт кўрсаткичини хисоблаш хақидаги маълумотларни тўплаш фаоллашди [1]. 2011 йил 19 июльда БМТ “Бахт: Ривожланишга мақсадли ёндашув” деб номланган Резолюцияни қабул қилди. Унда барча аъзо давлатларни ривожланиш жараёнини бахолаш учун қўллашга чақирилади. 2012 йил 2 апрелда БМТнинг порталида «Ялпи ички Бахт» - янги иқтисодий парадигма? деб номланган мақола эълон қилинди. Мақолада БМТнинг Бош котиби Пан Ги Муннинг конференциядаги "Бахт ва фаровонлик" нутқи мазмуни ўз аксини топган. Ўз нутқида БМТ рахбари ялпи ички махсулот кўрсаткичини иқтисодий ва сиёсий ривожланишнинг кўрсаткичи сифатида эътироф этиш билан бир қаторда жамиятнинг ижтимоий ва экологик холатларини ўзида мужассам этувчи янги кўрсаткични киритишни таклиф қилди[2].

Бахт тушунчасини хукуқий жихатдан белгиловчи нормалар 1776 йилда қабул қилинган АҚШнинг Мустақиллик Декларациясида белгиланган. Декларацияда “бахтга бўлган интилиш” ва бахтли бўлиш хукуқи хақида норма мавжуд. Шунингдек, АҚШ судларида бахт билан боғлиқ муносабатлар (happiness legal relations) юзасидан вужудга келувчи низоларни кўриб хал этиш амалиёти йўлга қўйилган[3].

1945 йилги Вьетнам Мустақиллик Декларациясида, Япония Конституциясининг 13-моддасида, Корея Конституциясининг 10-моддасида, ва Преамбуласида хам бахтли бўлиш ( бахтга эришиш) хуқуқи мустахкамлаб кўйилган.

Хукуқшунос Т.Зяблова фикрига кўра, бахтли бўлиш хуқуқи махсус тадқиқотни талаб этади. Бунда бирламчи ўринда бахт ва хукуқ тушунчалари ўртасидаги муносабатни ўрганиш зарур. Бир қарашда бахт хеч қандай тарзда хукук билан боғланган эмас деган фикр пайдо бўлади, бахт тушунчаси ўзининг мавхумлилиги билан қонунчиликнинг талабларига жавоб бериши имконсиз. Хукуқ нуқтаи назаридан бахтни ўрганиш шуни кўрсатадики, давлат ва хуқуқ нуқтаи назаридан бахт назарий мавхум тушунчадан кўпроқ амалий ахамиятга эга бўлган тушунчага айланиб бормокда[4].

Индонезияда оиланинг бахтлилик индексини аниқлаш махсус тести ва мобил илова яратилган бўлиб, оилавий низолар ва ажралишларни олдини олишда, оилани диагностика қилишда фойдаланиб келинмоқда. E-Happiness Tool мобил иловаси[5]да 20 та тест саволи берилади. Шунингдек, махсус вебсайт хам ишга туширилган бўлиб, унда Индонезия харитасининг қайси қисмларида бахтлилик индикаторлари орқали анқиланган натижалар намойиш этиб борилади. 
Малайзияда таълим жараёнини яхшилаш ва мониторинг юргизиш мақсадида Тэйлор Университетининг мухандислик мактабида янги ялпи институционал бахтлилик индекси (GIHI)жорий қилинган[6]. У орқали ууқитувчи ва талабаларнинг бахтлилиги ўлчанади. Ушбу индекснинг методологияси 9 та асосий доменга боғланган индикаторлардан иборат. Мазкур доменларга 1.Психологик хотиржамлик; 2.Соғлиқ; 3.Вақтни сарфлаш; 4.Таълим; 5.Маданий турли туманлик; 6.Яхши бошқарув; 7.Жамоа жизнеспособность; 8. Экологик турли туманлик; 9. Яшаш стандартлари. Улар ўз навбатида индикаторлар ва субиндикаторларга бўлинди. Ушбу индекс орқали мазкур мактаб ўқитувчилари ва талабаларининг фикри ўрганилиб таълим жараёнини яхшилаш устида иш олиб борилмокда.

Иқтисодий хамкорлик ва тараққиёт ташкилоти фаровон хаёт индекси (Better life index) орқали бахтлилик ва фаровонликни аниқлаб келмокда. Шунингдек, кенг оммалашиб келаётган индекслардан бири халқаро бахтлилик индекси хисобланади.

Happiness Index - Халқаро Бахтлилик индекси. Бахтлилик индекси бахтни, фаровонликни, мустахкам барқарорликни бахолайдиган кўрсатгичдир. 2012 йилдан бошлаб World Happiness Report хисоботларида эълон қилиниб келинмокда. Бахтлилик индекси хаётни қондириш, бахтиёрлик хисси ва бошқа психологик фаровонлик, соғлиқни сақлаш, вақт баланси, жамоа, ижтимоий қўллаб-қувватлаш, таълим, санъат ва маданият, атроф-мухит, бошқарув, моддий фаровонлик ва иш кабиларни қай даражада эканлигини аниқлаш мақсадида ишлаб чиқилган. Ушбу индекс билан Happiness Alliance, Global Happiness Council ва Gallup каби ташкилотлар иш олиб борадилар[7].

Индекснинг кўрсаткичлари: 1. ЯИМ (ялпи ички махсулот); 2. Ижтимоий қўллаб қувватлаш; 3. Кутилаётган умр давомийлиги; 4. Хаётий мухим қарорларни қабул қилиш эркинлиги; 5.Сахийлик; 6.Коррупция таъсири. Респондентларга 0 дан 10 гача бўлган шкала доирасида ахолидан сўровнома асосида аниқланади.

2020 йил World Happiness Report рейтинги бўйича Ўзбекистон 153 та мамлакат орасида 38-ўринни эгаллади. Мазкур индекс бўйича Финляндия 7.80 кўрсаткичи билан биринчи ўринда. Кейинги ўринларни Дания (7.64), Швейцария (7.56), Исландия (7.5), Норвегия (7.48) Нидерландия (7.44), Швеция, Янги Зеландия, Австрия ва Люксембург каби давлатлар эгаллашган. Шунингдек, етакчи давлатлардан Буюк Британия 13-ўринни, Германия 17-ўринни, АҚШ 18-ўринни, Франция 23-ўринни, Хитой 94-ўринни эгаллаган. Хиндистон, Малави, Яман, Ботсвана, Танзания, Марказий Африка Республикаси, Руанда, Зимбабве, Жанубий Судан, Афғонистон (2.56) рейтингнинг куйи поғоналаридан жой олган[8].

Бахтлилик индексини миллий кўрсаткич сифатида ўрнатган холда давлат ички сиёсатини йўналишлари ва бошқарувдаги камчиликларни аниқлаб жорий қилган давлатлар хам бор. Масалан, бугунги кунда кўплаб мамлакатларида жумладан Бутан Қироллиги, Бирлашган Араб Амирликлари[9], Хиндистон[10], Венесуэла, Нигерияда[11] “Бахт Вазирлиги” мавжуд.

Бутан Қироллигида, 1972 йилда Джигме Вангчук Бутан қироли томонидан Миллий Бахтлилик индексини жорий қилган[12].Уларда ЯИМ ялпи ички махсулот тушунчаси Ялпи Миллий Бахтлилик тушунчаси билан алмаштирилган. 1998 йилда Бутан хукумати "Бахтнинг 4 кўрсаткичи" номи билан янги режа қабул қилган. Уларга 1) иқтисодий ривожланиш; 2) атроф мухит мухофазаси; 3) миллий маданият тарғиботи ва самарали бошқарув; кўрсаткичлари киритилган. Улар хар икки йилда алмаштириб турилади. Шунингдек 72 та кўрсаткич буйича Бахтлилик ўлчанади. Мисол учун, медитация ва ибодат қилиш, худбинлик даражаси, рашк, совуққонлик, хамдардлик, сахийлик, ўз-ўзини ўлдириш фикрининг мавжудлиги кабилар. Давлатда буддизм қоидалари амал қилади, коррупция умуман йўқ қилинган, яхши экологик таббий мухит яратилган, химик ўғитлар давлатга умуман киритилмайди, ахолининг кўпчилиги вегетарианлардан иборат. Бутан Конституциясида хам ахолининг бахтли турмуш тарзини кечириш учун шароит яратилган. Бутан хукумати томонидан хар бир фуқаронинг бахтини таъминлаш имкониятини яратиб берувчи дастур ишлаб чиқилган.

Франция 2008 йилда Николя Саркози иқтисодий ютуқлар ва ижтимоий ўсишни аниқлаш бўйича махсус комиссия ташкил қилган. Комиссия хаёт сифатини аниқлашнинг кўрсаткичларига ривожланиш барқарорлиги, фуқароларнинг сиёсий хуқуқлари, экология даражасини киритган[13]. Комиссия иши якунлангач Саркози давлатда Бахтиёрлик ва тиббий хизматга бўлган имконни ўлчаш мезонларини киритишни таклиф қилган.

Буюк Британия 2010 йилда Миллий Бахтиёрлик индексини аниқлаш учун 2 миллион фунт стерлинг ажратди. Буюк Британия Бош вазири Д.Кэмерон томонидан хам хукукматнинг ишлаш кўрсаткичи сифатида жорий қилишни таклиф қилган[14]. Индекс социологик сўровномалар асосида аниқланган. Сўровномалар натижасида британияликлар учун мустахкам соғлиқ, оила 
ва яқин инсонлар билан илиқ муносабатлар хамда севимли иш бахтиёрлик хиссини бериши аниқланган. Буюк Британия хам ўз миллий индекси орқали жамият ва давлатда мавжуд муаммоларни аниқлаш хамда уларга ечимлар топишда фойдаланмоқда. Шунга қарамай олимлар ва сиёсатчилар бу борада бахслашиб келмоқдалар. Позитив психология намоёндаси Мартин Селигман Британия хукуматини кўпроқ инсонларнинг фаровонлигига эътиборни қаратилишни, бахт тушунчасининг аниқ илмий таърифга эга эмаслиги ва турли инсонлар учун турлича ахамият касб этишини эътиборга олишликка чақирган. Бу борада Селигманнинг “бахт тушунчасидан фаровонлик ғояси сари” концепциясида психолог олим фаровонликнинг кенг тушунча эканлигини хамда унинг афзалликларини қўллашнинг психологик хусусиятларини тушунтиришга харакат қилади[15].

Хитой 2011 йилда 16 та кўрсаткич асосида ўз Миллий Бахтлилик индексини жорий қилди. Индекс илмий тадқиқотлар, таълим, маданият ва спортга бўлган харажатларни инобатга олади. Бундан ташкари, хар бир инсоннинг яшаш майдон метражи, хар 1000 та фуқарога шифокорларнинг тўғри келиши, яшил экинлар майдони ва хатто ЯИМ хажмига нисбатан карбонат ангедриднинг эмиссия хажми хам киритилган. Хитойда Хэнань провинциясида мансабдор шахсларни иш фаолиятини бахолаш учун Бахтлилик индекси жорий килинган. Хитойда хам хукумат томонидан ахоли турмуш даражасини кўрсатиб берувчи 16 та кўрсаткич жорий қилинган. Бахтлилик индекси Хитойда давлат мансабдор шасхларининг иш самарадорлигининг кўрсаткичи хисобланади. Салбий натижалар олинганда кадрлар тизимида ўзгаришлар ўтказилган. Хэнань деб номланувчи провинцияда бахтлилик индекси кўлланиб келмокда, кўрсаткичлар натижасида ишдан бўшатишлар амалга оширилди ва кўплаб амалдорларга хизмат бўйича даражаларини ошириш аризалари рад этилди[16].

Японияда Аракава шахрида Бахтлилик индекси ишлаб чиқилди ва Япония хукуматига бутун давлат миқёсида жорий этиш таклифи киритилди. Аракава Бахтлилик Индексини (GAH) яратишда 2009 йилда Аракава шахар махаллий хокимият учун илмий тадқиқот институти ташкил этилди. Мазкур институт махсус илмий гурух тузулиб улар томонидан ахоли фикри сўровномалар ва интервьюлар статистик тахлил ва мухокама давра сухбатлари орқали индикаторлар шакллантирилди. 2 хил ёндашув танлаб олинди яьни -аниқ мақсадга асосланган ва эхтиёжларга асосланган. 2006 йилдан бошлаб хар йили ўтказилиб келинадиган Аракава шахар жамоат фикри хам олиниб тахлил қилинди. Ахоли фикрини ўрганиш чоғида кўплаб мунозаралар хам келиб чиқди. Улардан бири бахт тушунчасининг қувонч, шодлик каби тушунчалардан фарқи, шунингдек хаётдан қониқиш тушунчаси билан айни эмаслиги бахсларга сабаб бўлди. Шунингдек, GAНни шакллантиришда субъектив бахт танлаб олинадими ёки объектив бахт танлаб олинадими деган узоқ тортишувлардан сўнг респондентлар - хам субъектив, хам объектив бахт эътиборга олиниши ёқлаб овоз бердилар. 5 йил (2006-2010)ичида сўровномалар асосида йиғилган Аракава шахри ахолисининг фикри 86\% респондент “соғлом бўлиш"ни биринчи навбатдаги бахт кўрсаткичи эканлигини ва кейинги ўринда 56\% “оила билан яхши муносабатда бўлиш”ни ёқлаб овоз берганлар. Шундан сўнг 2011 йил августда Аракава шахри хукумати томонидан бахтлилик индекси жорий қилинди. Аракава бахтлилик индекси (GAH-Gross Arakawa Happiness) 6 та мухим индикаторлар асос қилиб олинди[17]:

1. Узоқ умр ва соғлиқни таъминловчи шахар;

2. Болаларга ғамхўрлик ва таълимни таъминловчи шахар;

3. Инновацион саноатга бой шахар;

4. Атроф табиий мухитга кўпроқ эътибор қаратадиган шахар;

5. Маданият ва яратувчанлик шахри;

6. Тинч ва хавфсиз шахар.

Япониядаги мазкур лойиха шахар хокимиятини ўз худудида яшовчи ахолини бахтлироқ қилиш учун ва уни аниқлашда ёрдам сифатида қўлланиб келинмоқда.

Хорижий давлатлар тажрибасини тахлил қилиш натижасида кўзга ташланаётган ижобий хусусиятлар билан бир қаторда салбий холатлар хам мавжуд. Бахтлилик индексини жорий қилишнинг самарадорлик даражаси Бутан Қироллиги, Хитой, Япония ва Бирлашган Араб Амирликларида кузатилмоқда. Ушбу давлатларда ахолининг турмуш даражаси, ижтимоий таъминот масалалари ва унда хам иқтисодиёт хам тўғри йўналтирилган сиёсат ва бошқарувга эришилганлигини кузатиш мумкин. Венесуэла ва Хиндистонда Бахт Вазирлиги ташкил этилганлигига қарамасдан, улар амалда иш самарасини бермаган. Камбағаллик, оддий гигиеник холатларнинг паст даражадалиги ачинарли[18].

Шу ўринда савол туғилади нима учун бундай қарама қарши холатлар юзага келган ? Назаримизда мазкур бугунги кундаги жараёнларда қуйидаги омилларнинг таъсири мавжуд: 
Биринчидан, бахт тушунчасининг хануз мавхумлилиги ва унинг илмий фалсафий жихатларини конкретлаштириш имкониятларининг чегараланганлилиги;

Иккинчидан, бахт тушунчасининг субъектив характерга эга эканлиги;

Учинчидан, жорий қилинган бахтлилик индексларининг методологияси ва индикаторларнинг турлилиги хам ўз навбатида бошқарув самарадорлигига таъсирини ўтказиши мумкин хамда бахтни ўлчовчи ягона методика хали ишлаб чиқилмаганлиги;

Тўртинчидан, Бахтлилик индекси асосланаётган ахолининг сўровномаларда иштирок этиш хохиш истагининг сустлиги. Жумладан, Россия тадқиқотчилари бугунги кунда ижтимоий сўровномалар инқирозга дуч келганлигини бунинг сабаби уларга ишончнинг йўқлиги, кўплаб фуқаролар уларга хеч ким қулоқ солмаслигини бунга вақт кетгазиш ахамияти йўқлиги хамда хавфсиз эмаслигини билдиришган. Ахоли нигохида ижтимоий сўровномалар мустақил институт сифатида кўрилмаётганлиги қайд этилди. Мазкур жараён Қозоғистонда хам кузатилмокда[19].

Хулоса қилиб, Ўзбекистонда бахтлилик индексини жорий қилишда қуйи поғонада оилаларнинг бахтлилик индикаторларини ишлаб чиқишдан бошлаб, махаллаларда низоли оилалардаги ажралишларни олдини олишда хамда махалладаги масъул шахсларни фаолиятларини мониторинг қилишдан бошлаб, синов тариқасида пилот худудларда жорий этиш мақсадга мувофиқ хамда хорижий мамлакатларнинг ижобий тажрибаларидан фойдаланиш ўринли.

\section{Манба ва адабиётлар:}

1. Зяблова Т.Е. Комарова Я.Б. Право на счастье и его содержание. // Вестник Владимировского юридического института №2(47) - 2018. -С. 178-184.

2. Алексеева И.Ю. Индекс счастья и конец истории// Философия и общество.№ 4, 2019 C.56-64. https://news.un.org/ru/story/2012/04/1199561

3. Солопова Н.С. Право на счастье на стремление к счастью в конституционном праве США и ОАЭ: вопросқ соотношения, реализации и судебной защиты.// Вестник современных исследований. 2018 с.229-231.

4. Зяблова Т.Е. Комарова Я.Б. Право на счастье и его содержание./ Вестник Владимировского юридического института №2(47) - 2018. -С. 178-184.

5. Hendarno A. E-Happiness Tool (web application), measuring of poor family happiness.// advances in social science and humanitites research (410) 2019. P.13-18

6. Applasamy V. Measuring happiness in Academic Environment: A case study of the school of engineering at Taylors University (Malaysia)// Procedia Social and Behavioral Sciences. 123(2014) P.106-112.

7. Musikanski L. Happiness index Methodology. Walden University https://scholarworks.waldenu.edu /cgi/ viewcontent.cgi? article $=1131 \&$ context $=$ jsc

8. https://worldhappiness.report/

9. https://u.ae/en/about-the-uae/the-uae-government/government-of-future/happiness

10. https://www.bbc.com/news/world-asia-india-38741238

11. https://www.bbc.com/russian/international/2011/07/110722_bhutan_happiness_index_un

12. Шматова Ю.Е., Морев М.В. "Измерение уровня счастья: литературнқй обзор российских и зарубежнқх исследований.// Экономические и социальнқе переменқ: фактқ, тенденции, прогноз 3(39)2015. С. 141-162.

13. Зяблова Т.Е. Комарова Я.Б. Право на счастье и его содержание. Вестник Владимировского юридического института №2(47) - 2018. -С. 178-184.

14. Селигман М. Путь к процветанию, новое понимание счастья и благополучия.-М.: Манн,Иванов и Фербер.-2013. -440 с.

15. https://forbes.kz//life/opinion/nujno_li_kazahstanu_ministerstvo_schastya/

16. K.Kentaro. A case study of Happiness Index by Local Government: Gross Arakawa Happiness (GAH) in Arakawa City//https://core.ac.uk/download/pdf/144440843.pdf

17. https://vokrugsveta.ua/unique/ministerstva-schastya-gde-oni-est-i-zachem-ih-sozdayut-2301-2017 https://forbes.kz//life/opinion/nujno_li_kazahstanu_ministerstvo_schastya/ 


\title{
ДУХОВНЫЕ И НАЦИОНАЛЬНЫЕ ОСОБЕННОСТИ ПОДГОТОВКИ МОЛОДЕЖИ К САМОСТОЯТЕЛЬНОЙ ЖИЗНИ В СЕМЬЕ
}

Умрихина В.И.,

преподаватель ТГПУ Низами, Узбекистан, Ташкент, v.umrikhina@mail.ru

\begin{abstract}
Аннотация: в статье рассматриваются вопросы подготовки к семейной жизни молодежи Узбекистана. Рассматриваются аспекты формирования у молодежи осознанного подхода к планированию семьи, рождению и воспитанию детей.

Ключевые слова: подготовка к семейной жизни, планирование семьи, осознанное родительство.
\end{abstract}

В Узбекистане семья является непреходящей ценностью. Каждый житель страны с трепетом относится к семье.

В государстве ведется политика, направленная на сохранение и укрепление семейных уз. Подготовка к семейной жизни начинается в раннем детстве в семье и продолжается во всех типах учебных заведений.

Подготовка к семейной жизни - это комплекс мероприятий и взаимодействий, осуществляемых семьей, специалистами, социальными институтами и государством с целью поэтапной помощи подрастающему поколению в формировании супружеской и родительской идентичности и

развития готовности к браку, рождению и воспитанию детей. Это комплекс всесторонних взаимодействий с родителями, учителями, сверстниками, с другими людьми, со средствами культуры и массовой информации, в результате которых происходит осознание особенностей брачно-семейных взаимоотношений, развитие соответствующих чувств, формирование представлений, взглядов, убеждений, качеств и привычек, связанных с готовностью к браку и семейной жизни.

Целью подготовки к семейной жизни является вооружение юношей и девушек знаниями о брачно - семейных отношениях, формирование представлений об идеальной семье, потребностей в ее создании и родительстве, умений правильно строить внутрисемейные отношения, воспитывать будущих детей, развитие соответствующей системы ценностей.

Подготовка к семейной жизни должна осуществляться по направлениям: общесоциальная, мотивационная, этическая, правовая, психологическая, физиолого - гигиеническая, хозяйственно-экономическая, педагогическая.

Подготовка к семейной жизни происходит в определенной последовательности:

на первом ориентационном этапе строится перцепционный образ семьи, в основе которого лежит синтез духовно-нравственных ощущений. Разрешаются противоречия между представлениями о браке и объективными требованиями, которые брак предъявляет к человеку, приоритетом блага других и собственного блага;

на оценочно-смысловом этапе происходит с понимание и осмысление знаний о семье и семейных духовно-нравственных ценностях, умений и способов поведения в контексте этих понятий. Новые представления, понятия и ценности соотносятся с системой ранее усвоенного, в единое целое объединяются потребности, интересы, установки, позиции, национальные традиции;

на - ценностно - деятельностном этапе происходит присвоение субъектом личностного духовного смысла, духовная ценность становится личностной ценностью, регулятором образа жизни, семейные ценности «входят» в мировоззрение личности, человек обретает целостность мировоззрения и поведения.

Результатом является - готовность к браку- система социально-психологических установок личности, определяющая эмоционально положительное, активное деятельностное состояние личности, характеризующееся сформированностью мотивов, знаний, умений и навыков в области семейной жизни, установкой на создание крепкой, морально здоровой семьи.

Критериями готовности к семейной жизни становятся: правильное понимание роли семьи и брака, установка на вступление в брак, его обязательную регистрацию в органах ЗАГС; готовность принять систему обязанностей по отношению к своему брачному партнеру и детям; го- 
товность к конструктивному межличностному общению и сотрудничеству; готовность к самопожертвованию, альтруизм; эмпатия, этическая и эстетическая культура чувств и поведения; умение предотвращать / конструктивно разрешать конфликты; экономическая состоятельность и трудовая занятость; планирование семье - осознанное рождение и воспитание детей.

На наш взгляд, наиболее сензитивным в формировании готовности к семейной жизни является старший юношеский возраст $14-18$ лет и ранняя взрослость $18-25$ лет - период жизненного самоопределения и интереса к вступлению в брак. В Узбекистане молодежь рано вступает в брак. В Семейном Кодексе определен минимальный возраст для вступления в брак - 18 лет для юношей и девушек. Наша задача состоит в том, чтобы вступление в брак было осознанным решением молодых людей, которые крепко стоят на ногах, получили образование и могут самостоятельно нести ответственность за созданный союз.

При подготовке к семейной жизни мы считаем важным выделить педагогическую направленность - формирование ответственного родительства, субъективного ощущения себя родителем, готовность к обеспечению и воспитанию детей. Это связано с тем, что молодые супруги рано становятся родителями.

Осознанное родительство начинается с ответственного подхода к планированию рождения ребенка.

Планирование семьи - это комплекс мероприятий, направленных на снижение заболеваемости и сохранения здоровья женщин и детей, имеющих своей целью способствовать супружеской паре в решении следующих задач: избежать нежеланных беременностей; иметь только желанных детей; регулировать интервалы между беременностями; регулировать количество детей; контролировать выбор времени рождения ребенка в зависимости от возраста родителей.

Осознанное родительство - система взаимодействий ценностных ориентаций, родительских установок, ответственности, отношений, чувств и позиций. Это осознанность во всех видах взаимодействия с ребенком, глубокая связь с ним и разностороннее развитие его личности.

В чем заключается духовные и национальные-особенности подготовки в самостоятельной жизни в семье в Узбекистане?

Семья в Узбекистане - является непреходящей национальной ценностью, воплощением добра, света, любви к детям, почитания старших, чуткого отношения к ближним, чужому горю. Традиционно семье присуще верность, постоянство, забота, уважение, строгая дисциплина, культ родителей.

Главная цель семьи - рождение, воспитание детей и подготовка их к самостоятельной жизни.

Мальчика растят и воспитывают как кормильца - продолжателя рода, будущего отца, ответственного за свою семью. Девочку - как будущую мать, верную и целомудренную хранительницу очага, обладающую премудростями ведения домашнего хозяйства, гостеприимства, воспитания детей, носительницу национальных традиций.

\section{Литература:}

1. Постановление Кабинета Министров Республики Узбекистан О мерах по дальнейшему развитию семьи и подготовке молодежи к семейной жизни Ташкент 2020

2. Семейный Кодекс Республики Узбекистан

3. Мухсиева А.Ш. Семейная педагогика/ учебное пособие Ташкент, 2018.

4. Подготовка молодежи к семейной жизни и осознанному родительству: учеб. метод. материалы/ авт. - состав. Комарова И.А., Могилев, 2012. 


\title{
НРАВСТВЕННОЕ ВОСПИТАНИЕ КАК ОСНОВА РАЗВИТИЯ ГАРМОНИЧНОЙ ЛИЧНОСТИ
}

\author{
Урумбаева Айгуль Нагметовна \\ кандидат педагогических наук, доцент \\ Нукусский государственный педагогический \\ институт им. Ажинияза
}

\begin{abstract}
Аннотация: В статье рассматриваются вопросы нравственного воспитания как основы развития гармоничной личности. На анализе педагогических взглядов великого русского писателя Л.Н.Толстого раскрывается сущность и содержание нравственного воспитания в формировании личности, подчёркиваются его значение и роль.

Ключевые слова: нравственное воспитание, основа, развитие, гармоничная личность, великий русский писатель Л.Н.Толстой, педагогика, управляемый процесс.

Abstract: The article deals with the issues of moral education as the basis for the development of a harmonious personality. The analysis of the pedagogical views of the great Russian writer Leo Tolstoy reveals the essence and content of moral education in the formation of personality, emphasizes its significance and role.
\end{abstract}

Key words: moral education, foundation, development, harmonious personality, great Russian writer Leo Tolstoy, pedagogy, controlled process.

Известно, что нравственное воспитание ребёнка как развитие гармоничной личности составляет одну из главных задач современного общества. Преодоление отчуждения человека от его подлинной сущности, формирование духовно развитой личности в процессе исторического развития общества не совершается автоматически. Оно требует усилий со стороны людей, и эти усилия направляются как на создание материальных благ, объективных социальных условий, так и на реализацию открывающихся на каждом историческом этапе новых возможностей для духовно-нравственного совершенствования человека. В этом двуедином процессе реальная возможность развития личности обеспечивается всей совокупностью материальных и духовных ресурсов общества.

Однако наличие объективных условий само по себе ещё не решает задачу формирования развитой личности. Необходима организация систематического, базирующегося на знании и учёте объективных закономерностей развития личности процесса воспитания, который служит необходимой и всеобщей формой этого развития.

Ещё на рубеже XX столетия великий русский писатель Лев Николаевич Толстой поставил перед всем человечеством чрезвычайно простой и одновременно архисложный вопрос: Что же происходит с человеком в современном мире? Почему простые и ясные основы его жизни, как труд, забота о ближнем, любовь и бережное отношение к природе, сострадание к человеку и мн. др. вдруг начинают терять для него весь свой смысл и значение?

Что же такое эта самая «цивилизованность» современного человека, если благодаря ей он утрачивает целостность нравственного сознания и начинает стремиться к самым варварским формам саморазрушения, зачастую сам не замечая этого? При этом писатель как бы предчувствовал, какие чудовищные формы примет в «массовом» сознании обывателя XX столетия эта «эмансипированная» стихия «животности».

Пытаясь разобраться во всём этом, Л.Н.Толстой вскрыл противоречия нравственного бытия человека современного общества, указав, что главная причина утраты им веры и осмысленности своего существования кроется в слепом эгоизме, извратившем духовно ценностную природу познания.

Отвергая представление о существовании человека исключительно как биологического существа, всецело подчинённого диктату инстинктов, писатель не отрицал полностью власть «природы» над человеком, а также не возлагал все надежды по усовершенствованию человеческого бытия на деятельность его разума.

Наоборот, он неоднократно подчёркивал, что чрезмерная рационализация бытия человека ни в коей мере не приблизит его к постижению смысла жизни. По глубокому убеждению Л.Н.Толстого, только способность личности возвыситься над своим естеством и опираясь на него, как на необходимое условие существования, утверждать разумные, истинно человеческие 
основы бытия - есть единственный критерий осмысленности её жизни.

По мнению писателя, обессмысливание представления о жизни, происходящее в результате полного порабощения человека «плотью», служит самым главным препятствием на пути постижения им смысла своей жизни, в то время как освобождение из-под её власти вновь возвращает его к самому себе как духовному и нравственному, человеческому существу - Homo moralis. Это открытие человека в себе бесконечности своей сущности, которая и становится единственным реальным основанием бесконечности своего существования, и есть, как, у утверждал Л.Н.Толстой, тот высший смысл жизни, который может стать доступен каждому человеку.

Однако, в суждениях о возможных путях достижения целей нравственного воспитания, Л.Н.Толстой, как известно, отводил основную роль нравственному просвещению, разделяя при этом взгляды просветителей XVIII века. Разумеется, нравственное формирование личности не равно нравственному просвещению. Установлено, что ценностно-ориентированная внутренняя позиция ребёнка возникает не как итог некоторых «педагогических воздействий» или даже их системы, а в результате организации общественной практики, в которую он включён.

Однако организация общественной практики воспитания личности ребёнка может быть ориентирована двояко. Один тип направлен на воспроизведение уже сложившегося социального характера. Такому типу организации соответствует приспособление педагогического процесса под уже достигнутый уровень психического развития ребенка. Подобная организация воспитания ни в коей мере не соответствует целям построения гуманного общества, поскольку здесь требуется решение задачи преобразования сознания человека.

В связи с этим, современные учёные и педагоги-практики исходят из того, что воспитание не может плестись «в хвосте детского развития», ориентируясь на его вчерашний день, а должно соответствовать «завтрашнему дню детского развития». В этом тезисе чётко отражается принцип подхода к психическому развитию личности как к управляемому процессу, который способен создавать новые структуры личностных ценностей растущих людей.

Управление процессом воспитания, осуществляемое как целенаправленное построение и развитие системы задаваемой многоплановой деятельности ребёнка, реализуется педагогами, вводящими детей в «зону ближайшего развития». Это означает, что на определённом этапе развития ребёнок должен продвигаться дальше не самостоятельно, а в сотрудничестве и под руководством взрослых.

\section{Использованная литература:}

1. Выготский Л.С. Педагогическая психология // М., 1990

2. Леонтьев А.Н. Избранные психолог. произведения, Том 1.// М., 1983

3. Мудрость воспитания. Книга для родителей // Москва, 1989

4. Толстой Л.Н. Полное собрание сочинений // Москва, 2001 


\title{
МАКТАБ ЎКУВЧИЛАРИДА ТАРИХИЙ ТАФАККУРНИ РИВОЖЛАНТИРИШ
}

\author{
Хайдаров Усмон Амиркулович \\ ТДИУ қошидаги академик лицей ўқитувчиси \\ uhaydarov86@gmail.com
}

\begin{abstract}
Аннотация. Ўкувчиларда тарихий тафаккурни ривожлантиришга доир таянч, фанлараро ва хусусий компетенциялар тизими тарих хамда миллий истиқлол ғояси ва маънавият асослари туркумига кирувчи одобнома, Ватан туйғуси, миллий истиқлол ғояси ва маънавият асослари фанлари бўйича узвийлаштирилган.

Калит сўзлар: Компетенциялар тизими, умумий ўрта таълим, битирувчилар, малака талаблар, ўкув дастурлари, дарслик ва ўкув қўлланмалар.
\end{abstract}

КИРИШ. Таълим-тарбия жараёнида педагогик инновацияларни кенг миқёсда қўллаш жахон тараққиётининг глобал тенденцияси хисобланади. Айни пайтда интерфаол таълим мухитини яратиш, ўкувчиларнинг тафаккури ва дунёкарашини ривожлан тиришнинг инновацион метод ва технологияларини такомиллаштириш янада мухим ахамият касб этмокда.

Мамлакатимиз мустакилликка эришгач, янги демократик таълим концепциясини яратиш вазифасига алохида эътибор қаратилди. «Таълим Узбекистон халки маънавиятига яратувчилик фаоллигини бахш этади. Ў сиб келаётган авлоднинг барча энг яхши имкониятлари, унда намоён бўлади, касб-кори махорати узлуксиз такомиллашади, катта авлодларнинг доно тажрибаси англа бўлинади ва ёш авлодга ўтади. Ёшлар, уларнинг иктидорлилиги ва билим олишга чанкоклигидан таълим ва маънавиятни тушуниб етиш бошланади» деган қатъий хулосага келинди.

АДАБИЁТЛАРТАХЛИЛИВАМЕТОДОЛОГИЯСИ.Тарихийтафаккурниривожлантириш тарих фалсафасининг мухим йуналиши сифатида Шарқ мутафаккирлари Абу Наср Форобий, Абу Райхон Беруний, Алишер Навоий, Махмудхужа Бехбудий, Абдурауф Фитрат, Абдулла Авлоний, Абдулла Қодирий кабиларнинг илмий-адабий йуналишлари асосини ташкил этган. Умумтаълим мактаби ўкувчиларида янгича тафаккур тарзини шакллантиришнинг миллий модели Ш.Э.Курбонов, У.И.Иноятов, Э.А.Сейтхалилов, Ш.С.Шарипов, Э.Р.Юзликаевалар томонидан тадқиқ этилган.

НАТИжАЛАР. Умумтаълим мактаби ўкувчиларида тарихий тафаккурни ривожлантиришнинг нейропедагогик хусусиятлари ва диагностик тизими аниқлаштирилган; фалсафий-антропологик ёндашув асосида ўкувчиларда тарихий тафаккурни ривожлантириш босқичлари, мазмуни, шакл, метод ва воситаларини яхлитликда ўз ичига қамраб олган локалмодулли технология ишлаб чиқилган. Ўкувчиларда тарихий тафаккурни ривожлантиришга доир ўқитувчининг инновацион фаолиятини ташкил этиш моделлари ва супервизорлик амалиётини ташкил этишнинг дидактик таъминоти ишлаб чиқилган; «тарихий тафаккур», «дидактик таъминот», «модернизациялашган дидактик таъминот», «умумтаълимий компетенция», «ахборот истеьмоли маданияти» каби тушунчаларнинг мазмун-мохияти хамда тарихий тафаккурнинг таркибий қисмлари (тарихий онг, тарихий билим, тарихий хотира, тарихий дунёқараш) муаллифлик ёндашуви асосида педагогик талкин этилган; ўкувчиларда тарихий тафаккурни ривожлантиришга доир омилларнинг яхлит тизими аниқлаштирилган ва модернизациялашган дидактик таъминот мазмунида ўз ифодасини топган;

Тарихий тафаккур фуқаролик жамиятини тараккий эттиришнинг мухим омили бўлиб, ўтмишни англаш, уни тўғри тушуниш орқали ўқувчиларнинг онги ва рухиятида жиддий ўзгаришларни таркиб топтириш, бу орқали хаётни, турмуш тарзини маънавий ислох қилишга эришилади. Тарихий тафаккур атамаси ва унинг педагогик мазмуни, таркибий қисмлари, ўкувчиларда тарихий тафаккурни ривожлантириш омиллари илмий асосланди. Тахлиллар натижасига кўра, тарихий тафаккур - миллий мустакиллик ва тараққиётнинг «ўзбек модели» асосини ташкил этиб, у ўқувчи томонидан яхлит тарихий воқеликни ўзлаштириш, уларнинг ўзаро муносабати хамда алоқадорлигини умумлаштириш орқали тарихий жараёнларнинг туб мохиятини англаш, тарих сабоқларидан оқилона хулоса чикариш қобилиятидир, деган таърифни беришимиз мумкин.

Дидактик таъминот ўкувчиларда амалий фаолият тажрибасини ўзлаштириш учун ахборотларнинг тўлиқлиги ва етарли хажмда бўлиши, ўқитувчи ва ўқувчиларнинг 
биргаликдаги интеллектуал-эмоционал ўзаро харакати мазмуни ва усулларининг вариативлиги, интерфаоллик, диалоглик, муаммолилик, амалий йуналтирилганлик тамойиллари асосида ишлаб чиқилган дидактик воситаларнинг ракобатбардошлилиги ва тартибга солинганлиги билан тавсифланади. У ўқувчиларнинг ахборотларни ўзлаштириш жараёнини ташкил этиш, назорат қилиш ва коррекциялаш мақсадида фойдаланилади хамда таълим олувчи шахсини шакллантириш ва ўз-ўзини ривожлантириш воситаси бўлиб хизмат қилади.

Илмий-назарий адабиётлар хмда ўкувчиларда тарихий тафаккурни ривожлантириш бўйича амалиётдаги холатни ўрганиш мазкур муаммонинг ечимини топишда қуйидаги масалаларга эътибор қаратишни талаб этди:

-ўқувчиларда тарихий тафаккурни ривожлантиришда умумтаълим босқичлари ўртасида узвийлик ва узлуксизликни таъминлаш;

-ўқувчиларда тарихий тафаккурни ривожлантириш жараёнига компетент ёндашувни татбиқ этиш, умумтаълимий компетенцияларни лойихалаштириш босқичларини аниқлаш;

-ўкувчиларда тарихий тафаккурни ривожлантиришнинг устувор йўналиши сифатида уларда ахборот истеъмоли маданиятини таркиб топтиришнинг педагогик механизмларини такомиллаштириш;

-ўкувчиларда тарихий тафаккурни ривожлантиришнинг нейропедагогик хусусиятларини тахлил этиш ва диагностик тизимини ёритиб бериш;

-фалсафий-антропологикёндашув асосидаўқувчилардатарихийтафаккурниривожлантириш технологиясини ишлаб чиқиш ва амалиётга татбиқ этиш;

-дидактик бирликлар сифатида кўриб чиқиш хамда таълимнинг анъанавий уч элементи: «Билим - Кўникма - Малака»ни яратади.

ХУЛОСА. Ўкувчилардатарихийтафаккурниривожлантиришмазкуржараёнсамарадорлигини оширишга хизмат қилувчи ижтимоий-сиёсий, миллий- маънавий, психологик ва педагогик омиллар хамда уларнинг модернизацион кўрсаткичларига боғлик; эканлиги илмий жихатдан асосланди. Модернизациялашган дидактик параметр сифатида компетент ёндашувни таълим амалиётига татбиқ этиш, умумтаълимий компетенцияларни лойихалаш технологиясининг ишлаб чиқилиши хамда умумтаълимий компетенцияларни аниқлаштириш компонентларининг ўзаро уйғунлигини тўлиқ таъминланишига эришиш ўқувчиларда тарихий тафаккурни ривожлантиришга доир таянч, фанлараро ва хусусий компетенцияларни белгилаш ва уларнинг амалий ахамиятини ошириш имконини берди. Глобаллашув шароитида ахборот хуружларининг турлари ва кўринишлари, ахборот тахдидларига қарши курашишнинг педагогик-психологик механизмларининг аниқланиши хамда ахборот истеьмоли маданиятининг концептуал ва ташкилий-технологик шарт-шароитларининг ишлаб чиқилиши асосида умумтаълим мактаби ўқувчиларида миллий тарихимиз ва ўзлигимизни англашга қарши ғайри шуурий фикрлар уйғотишга харакат қилишга қарши курашишга доир модернизациялашган иммунологик химоя тизими таркиб топтирилди.

\section{Adabiyotlar ro'yxati}

1. Xodjayev B.X.Falsafiy-antropologik yondashuv asosida o'quvchilarda tarixiy tafakkurni rivojlantirish texnologiyasi // Pedagogika. - Toshkent, 2015. - №1. - B.60-67. (13.00.00. № 6)

2. Xodjayev B.X. Falsafiy-antropologik yondashuv asosida o'quvchilarda tarixiy tafakkurni rivojlantirishning ayrim metodologik masalalari // Pedagogika. - Toshkent, 2015. - №2. - B.79-85. (13.00.00. № 6)

3. Xodjayev B.X. Respublika pedagoglarining ilmiy maktabi // Pedagogika. - Toshkent, 2015. - №4. - B.6-10. (13.00.00. № 6)

4. Xodjayev B.X. O'quvchi-yoshlarni axborot xurujlaridan muhofaza qilishda axborot iste'moli madaniyatining ahamiyati. // Xalq ta'limi. - ^shkent, 2015. - №5. - B. 92-95. (13.00.00. №17)

5. С.А. Хайдаров. (2020). Ўзбекистон тарихини ўқитишда “Зафарнома”дан фойдаланишни имкониятлари. Science and Education. 1(7). 192-198

6. Сулаймон Амирқулович Хайдаров. (2020). Тарих дарсларида интеграциялашган технологиялардан фойдаланиш. Science and Education. 1(8). 666-671

7. Хайдаров С. (2020). Ўзбекистон тарихи дарсларида педагогик технологияларни уйғунлашган холда қўллашнинг методик талаблари. Academic Research in Educational Sciences.1 (3). 1313-1321.

8. Хайдаров Сулаймон Амирқулович. (2020). Тарих фанини ўқитишга оид экологик му- 
аммолар масаласи «Scientific Progress» Scientific journal 1(1). 12-17.

С.А. Хайдаров. (2020). Тарих дарсларида тасвирий санъат асарларидан фойдаланиш. Science and Education. 1(9). 458-461.

Хайдаров Сулаймон Амирқулович. (2021). Ўзбекистон тарихи фанини ўқитишда тасвирий санъат асарларидан фойдаланишнинг ўзига хослиги«Scientific Progress» Scientific journal 1(3). 9-14.

9. Khaydarov S.A. (2021). The role of the use of fine arts in teaching the history of the country. International scientific and practical conference. CUTTING EDGE-SCIENCE. Conference Proceedings. Page 41-43.

10. Хайдаров. С. (2021). Ёшларда ватанпарварлик хиссини тарбиялашда "Бобурнома" асарига ишланган миниатюраларнинг ахамияти. Халқаро илмий-амалий конференцияси тўплами. 33-37 б.

11. Хайдаров. С. (2021). Захириддин Мухаммад Бобур хорижлик татқиқотчилар нигохида: подшохлик мўйқалами. Халқаро илмий-амалий конференцияси тўплами. 43-46 б.

СулаймонХайдаров. (2020). Ўзбекистон тарихи фани дарслари самарадорлигини оширишда тасвирий санъат воситаларининг роли. Science and Education, 1(6), 174-179.

C.А. Хайдаров. (2020). Педагог-ўқитувчиларда ахборот-коммуникация кўникмасини шакллантириш асослари.»Science and Education.» Scientific journal. 1(7).610-617 б.

Хайдаров.С. (2021). Рақамли таълим мухитида тарих дарсларида талабалар билимини назорат қилиш воситалари ва методлари. Халқаро илмий-амалий конференцияси тўплами. 160163 б. 


\section{СОЦИАЛЬНО-ПЕДАГОГИЧЕСКИЕ ОСОБЕННОСТИ ФОРМИРОВАНИЯ ЛИЧНОСТИ РЕБЕНКА В НЕПОЛНОЙ СЕМЬЕ}

Шаумарова Зилола Абдушукуровна

$\mathrm{PhD}$, в.б.доцент кафедры «Социальная педагогика» Ташкентского государственного педагогического университета

В мире обращается особое внимание защите правовой культуры ребёнка, созданию благоприятных условий для всестороннего гармоничного развития детей, повышению обязательств родителей по образованию и воспитанию детей. В соответствии с показателями исследования центра Pew Research Center ${ }^{1}$ самое большое количество неполных семей в США $-23 \%$. Во Франции и России - $18 \%$, Великобритании - $21 \%$ неполных семей. А в Китае и Вьетнаме количество неполных семей равно 3-4\%. На основании данных Всемирной организации здравоохранения (ВО3) ${ }^{2}$ одним из факторов, приводящих к суициду несовершеннолетних детей является среда неполной семьи; в настоящее время проводятся системные работы по исследованию социально-педагогических особенностей формирования личности.

В нашей республике обращается особое внимание укреплению института семьи, уменьшению количества разводов и как следствие количества в неполных семей, предупреждению преступности среди молодёжи и женщин, совершенствованию системы психологической и педагогической профилактики суицидального поведения. В Стратегии действий по дальнейшему развитию Республики Узбекистан предусмотрена дальнейшая реализация комплекса мер по укреплению здоровья семьи, защите материнства и детства, дальнейшее расширение пользования матерями и детьми качественными медицинскими услугами, оказанию медицинских услуг, основанных на специализированных для них и высоких технологиях, снижению смертности младенцев и детей. ${ }^{3}$

Неполная семья - это семья, в которой нет отца или матери, воспитанием ребёнка занимается отец или мать. Исходя из того, кто из родителей занимается воспитанием ребёнка, с кем проживает ребёнок, такие семьи называется отцовские или материнские неполные семьи.

Педагогические и психологические, социально-экономические особенности неполной семьи могут оказать влияние на формирование личности ребёнка в будущем. Выделены педагогические, психологические, социальные и экономические проблемы, оказывающие влияние на формирование личности ребёнка в неполной семье (см. рисунок 1).

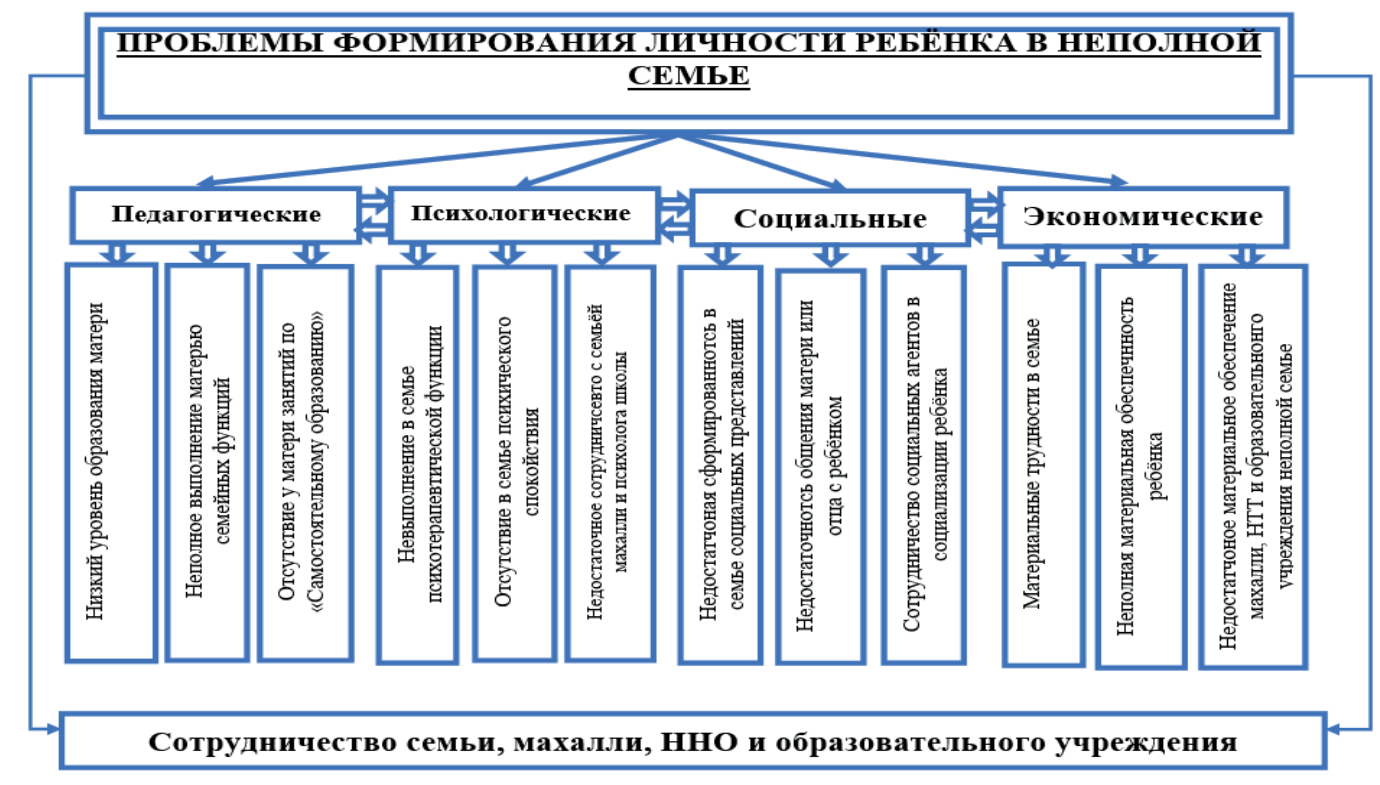

\footnotetext{
${ }^{1}$ https://www.pewresearch.org/fact-tank/2019/12/12/u-s-children-more-likely-than-children-in-other-countries-tolive-with-just-one-parent

2 ВОЗ. Предотвращение самоубийств: глобальный императив. ISBN: 978928905067 8. 2014 й. 102-б

3 Указ Президента Республики Узбекистан от 7 февраля 2017 года № УП-4947 «О Стратегии действий по дальнейшему развитию Республики Узбекистан”. - Собрание законодательства Республики Узбекистан, 13 февраля 2017 г., № 6, ст. 70.
} 
По уровню полноценного выполнения семейных функций неполные семьи условно можно разделить на следующие виды:

Семья, выполняющие эти функизии на высоком уровне. Это неполная семья, которая полноценно выполняет все функции, будучи неполной семьей временно или на протяжении долгих лет. В таких семьях в большинстве случаев помогают поколения зрелого возраста - дедушки, бабушки, которые вносят свой достаточный вклад в полноценное выполнение такой функции как материальное обеспечение. При этом (если это не семья вдов) супруг, находящийся в разводе, тоже по своей инициативе вносит, исходя их своих возможностей, достаточный вклад в выполнение семейных функций.

Неполная семья среднего уровня. В выполнение семейных функций супруг, не проживающий с семьёй, не вносит никакой вклад в выполнение семейных функций, кроме алиментов. В вопросах выполнения самой важной семейной функции - воспитание ребёнка - у матери, иногда у отца (если отец проживает с ними) встречаются достаточные трудности. Вместе с тем, мать в большинстве случаев из-за занятости трудовой деятельностью не выполняет в семье в достаточной степени психотерапевтические, регулятивные, коммуникативные функции.

Неполная семья, выполняющая функции на низком уровне. Семьи, где больше половины семейных функций не выполняется, дети предоставлены самому себе, мать часто не выполняет свои материнские обязанности, во многих случаях пьянствует, в семье постоянно царит нездоровая психологическая среда, материально состояние плачевное. Семейная среда такого вида встречается иногда и в полных семьях.

На наш взгляд, при формировании на уровне требований личности ребёнка в неполной семье необходимо обратить внимание на следующее:

1. Молодым матерям, воспитывающим ребёнка в неполной семье, необходимо оказывать педагогико-психологическую помощь. Психологи махалли могут оказывать эту помощь в форме педагогико-психологических тренингов, психологического мониторинга, педагогикопсихологической пропаганды, семинаров, специальной учёбы (в рамках университета родителей), специально подготовленных буклетов, брошюр и других формах. При этом необходимо учитывать специфические особенности, социально-экономическое положение каждой неполной семьи.

2. Необходимо организовывать встречи учащихся школ с известными артистами, спортсменами, учёными, руководителями, писателями, поэтами и другими, которые выросли в неполных семьях, беседы за круглым столом о том, как они достигли таких успехов, как преодолевали жизненные трудности. Целью этого является не идеализация неполной семьи, а обучение молодёжи, особенно, детей, достигающих совершеннолетия в неполных семьях, умению мобилизовывать волю для преодоления трудностей, встречающихся в жизни. Такие встречи оказывают также сильное воспитательное влияние на детей из неполных семей.

3. Целесообразно, чтобы над мальчиками, растущими в неполной семье (если свой отец не выполняет обязанность образца), взяли временное попечительство являющиеся всесторонне образцом родственники, соседи или близкие знакомые. Мужчина, взявший на себя попечительство, должен время от времени, наряду со своими детьми, культурно организовывать свободное время ребёнка, достигающего совершеннолетия в неполной семье, до тех пор, пока растущие мальчик или девочка полноценно не воспримут отношения в семье, статус отца и матери, образцовые отношения между ними и примут их в будущем для себя как образец.

4. Необходимо привлечь детей в неполной семье к спорту, музыке, изобразительному искусству и другому, с учётом врождённых наклонностей и интересов. 


\title{
THE EFFECTIVE USE OF INNOVATIVE TECHNOLOGIES IN TEACHING FOREIGN LANGUAGES
}

\author{
Bozorova Muborak Sharapovna \\ Tashkent Institute of Finance \\ A senior teacher of Uzbek and foreign \\ languages department
}

\begin{abstract}
Annotation: This articles examines the role of information technologies and effective ways of teaching foreign languages. It also discusses creation of multimedia apps and new methods of using Internet resources in teaching foreign languages.
\end{abstract}

The digital age has changed the conditions of life, formation and education. Everything changes around, and accordingly, the attitude towards learning must change. The role of innovation in education is great. The effective use of Innovative technologies, such as computers, the Internet, multimedia resources in the educational process is the only way to show the quality of education. One of the innovative technologies of improving the students' communicative abilities is using multimedia in the process of teaching and learning in the classroom. Proper use of multimedia in classroom will provide the opportunity for interacting with diverse texts that give students a solid background in the tasks and content of mainstream courses. Furthermore, because educational technology is expected to become an integral part of the curriculum, students must become proficient in accessing and using electronic resources. The uses of technology are wide open, and there are many ways to innovate the learning process there. To raise own culture, to develop and to go forward is a vital necessity of our century and the young state. The same vital necessity is the study of foreign languages in order to keep pace with the times. Today, knowledge of English opens a window into a large global world with its wide flow of information and innovations. Innovative methods of teaching are a goal of many educators. Teaching students in ways that keep them engaged and interested in the material can sometimes be a challenge.

This can prove especially true when it comes to high school students. In this short attention span world we now live in, thanks to the internet, it seems to be harder than ever to keep high school students excited and engrossed in learning what they're there to learn.

However, finding new and innovative methods of teaching can prove to be one of the best things an educator can do for high school students. Brain research has shown that certain methods and approaches can truly enhance the learning process for students. Encouraging them to visualize the outcomes they desire is one way to enhance lessons in all subjects. . Technology can provide students with opportunities for using important learning principles, such as pre-existing knowledge, mental models, active learning, transfer and learning for understanding. Applying innovative energy and attention-management techniques in schools is a win-win for both students and teachers. At the present stage of the development of the society, the modernization of the content of education in Uzbekistan is not connected with the innovation processes in the organization of teaching foreign languages. Therefore, the main goal of the modern teacher is to choose the methods and forms of organizing the learning activity of trainees, which optimally meet the goal. In recent years, the usage of new information technologies in schools has been raised increasingly. Since the main goal of teaching foreign languages is the formation and development of a communicative culture of schoolchildren, the training of practical mastering a foreign language, the use of computer technology, Internet resources is the best approach in teaching. It's been quite a few years since a computer entered our life, and we no longer imagine a modern lesson without the use of information technology.The using of multimedia in classroom cannot be denied anymore. That will make possible for teachers giving more opportunity to students being happier and more enjoy during the learning course. Through their interactions with multimedia texts, students become increasingly familiar with academic vocabulary and language structures. As they pursue sustained study of one content area through focus discipline research, the students become actively engaged in the process of meaning construction within and across different media. Learners obtain most of the information 
from electronic devices, which has made such tools, a very essential component of their daily life. Using innovative technologies in a classroom as a tool for language learning has many benefits. It gives stimulus to undertake the tasks. And could help in creating a long lasting impact on the learners. The role of teacher will change from an instructor's role to a coordinator.

Today, new methods of using Internet resources are opposed to traditional teaching foreign languages. To teach communication in a foreign language, you need to create real life situations that will stimulate the study of the material and develop adequate behavior. Now everyone understand that the Internet has tremendous information capabilities and no less impressive services. Many students have long appreciated all the advantages of the Internet and use its services actively in their educational process, while for teachers the space of this world web remains mostly unknown, unfamiliar and to some extent frightening. This is one of the forms of research organization and cognitive activity, in which group activity is successfullyrealized that allows to increase the motivation for learning a foreign language.As language teachers, we have a tradition of integrating new media into our teaching. We have embraced any new technology, which was likely to improve learning. These were replaced by reel-to-reel tape recorders when the price was right and appropriate recordings became available. The most important advantage is that media helps to improve their four language skills like listening, reading, speaking and writing. Moreover, information technology develops students' critical thinking. Furthermore, multimedia provides us with individualized learning, which means that multimedia resources can help you meet needs of many different types of learners. Like, Visual learners can watch a video, while auditory learners listen to streaming audio hands-on learners play and interactive game. Students who need extra practice can use online exercises to improve their grammar or vocabulary skills. In my opinion, multimedia resources can help our students to experience today's global community. With multimedia students can learn about new cultures and countries in immediate and authentic ways - and prepare to interact with that broader community. In addition, the last three points show that multimedia is oriented towards the learner's cultural background and addressing students' learning needs. Information and communication technologies are the most important parameter of contemporary socio-cultural system. Online Resources are familiar and convenient means of exploring the culture of other countries and peoples, communication, information, inexhaustible source of educational process. That is why, based on a systematic approach to reforming the methods of learning a foreign language using the new information technologies based on the concept of information and learning environment, which is seen in close connection with the system of developmental education.

\section{References:}

1. Dudley-Evans, T. Developments in English for Specific Purposes: A multi-disciplinary approach. Cambridge University Press, 1998.

2. Anthony Edward M. 'Approach, method and technique. English Language Teaching. -1963PP.65-67, 


\title{
TEACHING TEXT TYPES:"THE LAST LEAF" BY HENRY (BLOOM'S CUBE AND PRESS FORMULA)
}

\author{
Dildorakhon Nasirdinova \\ Military-academic lyceum "Temurbeklar maktabi"
}

\begin{abstract}
Annotation: The following article dedicated to the classification of different text types such as expository texts, narratives and argumentative texts, and teaching them through efficient pedagogical technologies. It emphasizes awareness of reading materials those consist of different text types is as essential as teaching. Moreover, it discusses theories on text types, different teaching technologies in teaching text types and proposes two interactive techniques such as Bloom's cube and PRES formula by thoroughly explaining and creating some examples on teaching Henry's "The last leaf".

Key words: expository text, narratives, argumentative texts, Bloom's Taxonomy, Bloom's cube, PRES formula.
\end{abstract}

President of the Republic of Uzbekistan signed a Resolution on June 28, 2019 that is dedicated to military-patriotic education of the Armed Forces military personnel of the Republic of Uzbekistan. In accordance with the Resolution fundamentally novel Military-academic lyceums "Temurbeklar maktabi" were established in the Ministry of Defense, Ministry of Internal Affairs, Ministry of Emergency Situations of the Republic of Uzbekistan, the State Security Service and the National Guard $^{1}$. According to the Resolution foreign language literacy and competence of the military personnel including the students of "Temurbeklar maktabi" academic lyceums were prioritised by the State education system. Over the last years the tendency and the whole attitude to the world and teaching foreign languages has been changed a lot. Integration in teaching language skills and systems has made sufficient progress in teaching languages. This made an effect on the quality and way of the educational system in our country too. One of priorities that is valued nowadays is multilingual abilities of our military serviceman and the youth of Uzbekistan.

Knowledge of text types helps language learners organize their thoughts when receiving, retelling or reporting on a particular reading. Students unaware of text types may become confused or include unnecessary details in reports or retellings of a read aloud. Knowledge of text type aids reading comprehension and assists learners in compartmentalizing texts. Explicit instruction of text type is vital to understanding how letters form words, words form sentences and sentences form paragraphs and they form meaning. Moreover, teaching text types helps develop writing which could also be used as a critical tool for thinking. Using different pedagogical technologies on teaching text types guarantees the effectiveness of teaching and fulfils the pedagogical aims of English classes.

A text is a piece of writing that you read, listen or create. The type or the characteristics of a text are very important for any work of summarisation on it. It is easier to select the main ideas from certain types of texts, as the narrative ones (texts "telling a story") then from others, such as expository texts (texts "speaking about"). The type of a texts depend on their purpose, structure and language features. One of the most commonly used classification text materials is that one based on text's purpose and meaning. In this classification, there are three main categories:

1. Expository texts

2. Narrative texts

3. Argumentative texts.

An expository text is intended to identify and characterise experiences, facts, situations, and actions in either abstract or real elements. Expository texts are meant to explain, inform or describe and they are the most frequently use to write structures. Expository structures can be classified into five categories:

$>$ description: where the author describes a topics characteristics, features, attributes, etc. and gives examples.

$>$ procedure or sequence: the author lists different activities in their chronological order or enumerates items in a numerical order.

${ }^{1}$ Mirziyoyev Sh.M O`smirlarni harbiy-vatanparvarlik ruhida tarbiyalash hamda O`zbekiston Respublikasi Qurolli Kuchlari va davlat xizmati uchun kadrlar zaxirasini tayyorlash tizimini takomillashtirishga oid qo'shimcha chora-tadbirlar to'g'risida// PQ-4375-T., Xalq so'zi,28-iyun 2019-yil. 
$>$ comparison: the author explains how two or more objects, events, experiences, are alike and/or different.

$>$ cause-effect explanation: the author presents ideas, events in time, or facts as causes and the resulting effect(s) in time.

$>$ problem-solution presentation: the author describes a problem and gives one or more solutions to the problem.

In the expository category, the non-fictional texts have specific role to inform or to teach the readers. They can come in a various formats, depending of the area of use:

$>$ business: reports, letters, executive summaries.

$>$ journalism: essays, news reports, press releases, sports news.

$>$ technical communication: user guides, technical reports or standards.

$>$ academic and scientific communication: textbooks, student guides, scientific reports, scientific journals' articles, encyclopedia articles.

$>$ general reference works: encyclopedia articles, or on-line, multi-domain informative texts, as the Wikipedia articles.

A narrative text entertains, instructs or informs readers by telling a story. Narrative texts deal with imaginary or real world and can be fictional (fairy tales, novels, science fiction, horror or adventure stories, fables, myths, legends, etc.) and non-fictional (articles, newspaper reports, historical writings).

Argumentative texts aim is to change the readers' beliefs. They often contain negative qualities or characteristics of something/someone, or try to persuade their readers that an object, product, idea is in some way better than others. We should note that few texts are purely one type: expository or argumentative texts can contain narration or evaluative elements. It's worth remembering that the text types refer to the meaning the writing, and they should not be confused with writing (or other materials) formats: book, article, letter, report, essay, etc.

There has been research in developing reading comprehension in the field of foreign language teaching for years. Although the studies on developing reading strategies are many in number in the ESL context, there are relatively few studies conducted specifically on the three phases of instruction in EFL context. Strategy training, therefore, is important in developing reading skills. At this point students' background knowledge is a contributory factor, especially in developing the pre-reading stage strategies since this knowledge will help the student on their predicting/guessing abilities. Solely, this stage will enhance the transition to the rest two strategies.

Also we can effectively use Bloom's cube in ESL teaching. This cube template uses the various levels of Bloom's Taxonomy to get students to think critically about the stories read in class. These can be used in groups and pairs. These are greatly differentiated instruction tools, as you can use different cubes for different groups (if you base groupings on ability level, learning style, etc.). You can print these out on card stock, cut, and assemble them with tape. They can be rolled like dice in the groups. Or you can purchase acrylic golf ball display cubes for greater durability.

\begin{tabular}{|c|c|c|c|}
\hline & $\begin{array}{l}\text { In your } \\
\text { opinion }\end{array}$ & & \\
\hline \multirow[t]{2}{*}{ Describe } & Explain & Develop & Classify \\
\hline & $\begin{array}{l}\text { Create a } \\
\text { new }\end{array}$ & & \\
\hline
\end{tabular}

We can apply above mentioned cube to comprehend narratives and stories too. For example, "The Last Leaf" is a short story (narrative) by O. Henry published in 1907 in his collection The Trimmed Lamp and Other Story.

The following cube can be used for the story: 


\begin{tabular}{|c|c|c|c|}
\hline & $\begin{array}{l}\text { In your opinion: } \\
\text { did you find the } \\
\text { story interesting/ } \\
\text { useful? }\end{array}$ & & \\
\hline \multirow[t]{2}{*}{$\begin{array}{l}\text { Describe: } \\
\text { When, where did the } \\
\text { story happen? }\end{array}$} & $\begin{array}{l}\text { Explain: Why is the } \\
\text { picture of the last } \\
\text { leaf important? }\end{array}$ & $\begin{array}{l}\text { Develop: Why the } \\
\text { picture of a leaf } \\
\text { is considered as } \\
\text { the masterpiece of } \\
\text { Behrman? }\end{array}$ & $\begin{array}{l}\text { Classify: What are } \\
\text { the similarities of the } \\
\text { time in the story to } \\
\text { the current Covid } 19 \\
\text { pandemic? }\end{array}$ \\
\hline & $\begin{array}{l}\text { Create a new: How } \\
\text { would you behave } \\
\text { if you were Sue/ } \\
\text { Behrman? }\end{array}$ & & \\
\hline
\end{tabular}

PRES formula technique provides students with a tool to develop their arguments and opinions. It helps them clarify their thoughts, and articulate and present their opinions clearly and concisely. The P.R.E.S. method provides a useful format for conducting controversial issue discussions and public policy lessons.

\section{Procedures:}

1. Post or provide a handout with the four steps in the P.R.E.S. method.

$>$ (P) State your point of view

(R) Give one reason for your point of view

$>$ (E) Give an example to clarify your reason

$>$ (S) Summarize your point of view

Here is the example of questions for "The last leaf" by Henry. This formula is efficiently organises post reading stage for the short story "The last leaf" by Henry:

What: What did you like most about the story?

Why: Why do you think so?

How: How did the plot of the story reflect on you?

What if: What if the artist hadn't drawn his masterpiece on the wall?

Students will have their own version of answers and these questions will help them to organize their thoughts precisely. Teacher should give some possible discourse markers to assist the students.

\begin{tabular}{|l|l|}
\hline Point & I think, in my opinion, in my mind \\
\hline Reason & Because, the reason why \\
\hline Example & For example, for instance, \\
\hline Summary & So, to sum up, to put in a nutshell \\
\hline
\end{tabular}

To sum up, awareness of reading strategies, integrating different aspects and using pedagogical technologies in teaching text types guarantee an effectiveness of teaching English.

\section{References}

1. Mirziyoyev Sh.M. "Together we will build a free and prosperous, democratic state of Uzbekistan." Speech at the joint session of the chambers of the Oliy Majlis dedicated to the inauguration ceremony of the President of the Republic of Uzbekistan. Tashkent, Uzbekistan. 2016

2. Alyousef, H. S. (2005). Teaching reading comprehension to ESL/EFL learners. The Reading Matrix,5(2), 143-154. 2018.

3. Armstrong, Patricia. "Bloom's Taxonomy." Center for Teaching, Vanderbilt University, 13 Aug.

4. Bloom, Benjamin Samuel. Taxonomy of Educational Objectives. New York: David McKay, 1956. 


\title{
THE MOST EFFECTIVE WAYS OF IMPROVING FOREIGN VOCABULARY
}

Ivliyeva Galina Gafurovna

a senior teacher Tashkent Institute of Finance

\begin{abstract}
Annotation: Teaching and learning English, which has become the most widely spoken language in the world, has already become an integral part of our lives. What is the most important and necessary thing in this system? Of course, this is the vocabulary of the language. This article also covers how to increase vocabulary of English and use it effectively in learning and teaching.
\end{abstract}

Language and speech are the means of communication of the universal being and apply not only to humanity but also to the whole world. Therefore, the field of language learning, which is becoming one of the most pressing issues of modern demand, is a great future foundation, especially for young generation. Nowadays, the English language is taking its first steps on every field as it covers the whole world. For example, in the field of education, this language can be divided into 4 stages, which include preschool education, secondary education, secondary special education and higher education. In addition, the rapidly growing business direction is also due to the strong ties established with foreign countries, which is directly related to the foreign languages, especially English.

The fact of the matter that when learning a new language, your focal point should always lean more toward finding new ways to improve your vocabulary rather than grammar. Regardless of whether you are studying English at school, enjoying your summer vacation or you are not even a student, at all, these 10 methods are your secure path to growth and enrichment in the English vocabulary department. Some statistics and scientists claim that words are the basic blocks of the language, and one of the key predictors of someone's education level, profession and social status. Below ten proven tactics to overcome learning problems and learn new words faster, recall them more effectively, and remember them forever.

Here you can get acquainted with the most effective tips of extending your banking vocabulary.

1. Make Friends with the Dictionary

A dictionary is the first indispensable resource to improve your vocabulary. It's only by looking up a word in a dictionary that you will learn its precise meaning, spelling, alternate definitions, and find much more useful information about it. A thesaurus is also a valuable resource for learning by finding connections between words, such as their synonyms and antonyms. Consider adding a good dictionary and thesaurus to your bookshelf. Here are some recommendations:

Oxford Advanced Learner's Dictionary; The New Oxford American Dictionary; The Oxford American Writer's Thesaurus.

\section{Make the vocabulary personal, and emotional}

You have probably heard stories of car crash survivors who can remember every little detail before the accident. We have also all experienced how difficult it can be to forget something we have been told that touched us to the heart. Rather than settling for a boring sentence like "The photo is on the table," try something like "The photo of my wife fell of the desk just when I got the call". There is now a very visual story forming around the vocab, it is emotionally impactful, and assuming you keep a photo of your significant other on your desk, also immediately relatable! Try to think of new vocabulary in context of the people you know, places you are familiar with or important events in your life. Just make sure not to go overboard with the imagery, lest you get traumatized every time you need to use one of the words...

\section{Have some fun with the words you learn}

Word games may not be enough in and of themselves, but they are a fun and effortless way to increase the recall speed of the vocabulary you know already, as well as to pick up an occasional new word from your peers. You may, for example, try your own variation of "Word Evening": at a specific day of each week, a different person brings a new word to the meal. The person reads the word, defines it, and the others must come up with a sentence using the word.

\section{Make each new word meaningful}

Research has shown that our brain understands new verbal concepts better when they are linked to an image or another concept. For example, if you learn the word "temperament", you may link its meaning to "temperature" to memorize it easier, and more importantly, be able to recall its meaning 
based on that connection at any given time. The concepts you connect do not have to be related in any way as long as they help you memorize new vocabulary.

\section{Make observations}

Once you have a specific amount of words in your vocabulary list, try to look at the world around you to find examples of their usage, e.g. in songs, movies, newspapers, etc. This is highly beneficial because not only can you observe the context this new vocabulary is being used in but you can also see the collocations that can be formed, as well - something you cannot necessarily achieve by sheer flipping through a dictionary. Knowing when and how vocabulary is used is actually more important than just knowing its meaning.

\section{Use Lists and Flash Cards}

It can also be helpful to learn new words in groups centered on a particular theme. You can use a textbook to find useful vocabulary word lists, or you can look online for ready-made flash cards to practice new words by category. Your dictionary, flash cards can be tailored to your own interests and then shared with others, or you can browse some collections to find an existing list that covers that topic. Flash cards are a great way to study for a test, prepare for the SATs (Standard Assessment Test) or just explore vocabulary for your personal enjoyment.

\section{Learn a Word Each Day}

There is a reason why word-a-day desktop calendars are so popular. Adding to your vocabulary in small bites is very manageable and more easily remembered. You may even find yourself looking forward to a new ritual of reading about an interesting word, its definition and linguistic heritage. If you do not want a physical calendar, try using an online dictionary to look up words at random every morning before you open your email. You can also try downloading a daily vocabulary app or game to play on your smartphone for a few minutes each day.

\section{Follow a Process}

To make vocabulary improvement a permanent habit in your everyday life, you should make it as habitual, automatic and tightly integrated in your daily workflow as possible - otherwise you will not do it when your days get too busy.

\section{Diversify}

Do something different from your daily routine: hunting, fishing or blogging - any activity that is not a part of your normal life can become a great way to learn new words, as every niche has its own jargon and unique ways of communicating. Read different books and magazines than the ones you are used to. Watch foreign-language movies. Take up new hobbies, hang out with different people. By doing things out of the ordinary you will not only improve your vocabulary but also make your life much more interesting.

10. Discover your own words.

Take a new approach to each new word you memorize. Is it hard to remember or pronounce them? So, different pictures, characters and colors will help you. Always stick the words you are learning in eye-catching places with pictures, and find that word by giving it your own description every time you look at it. Imagine if you memorized every word that was difficult for you in this way, a new world would appear in your life. Then these words in the common language have their own meaning, that is, the same for everyone, but they mean the same thing to you based on your own worldview.

\section{Used literature:}

1. Grabe, W., \& Stoller, F. L. (2002). Teaching and researching reading. New York: Pearson Education.

2. Bull, S., \& Ma, Y. (2001) Raising learner awareness of language learning strategies in situations of limited recourses.

3. Harmer, J. (2007). The practice of English language teaching. England 


\title{
APPROACHES TO THE STUDY OF LEGAL DISCOURSE IN LINGUISTICS
}

Jumaniyozova N.A

Uzbekistan state world languages university

\begin{abstract}
Annotation: This very article partly discusses the approaches of the study of legal discourse in linguistics and its main peculiarities. It also provides some examples in order to prove its actuality. Legal discourse is an important and urgent research problem, since it is an integral part of modern society. Many works in the field of linguistics are devoted to the study of this concept and our main goal within this article is to put more emphasizes on the types of discourse with their characteristics, the definition of legal discourse and its functions as well as approaches.

Key words: Legal discourse, approaches, discourse analysis, institutional discourse, functions, communication, framework
\end{abstract}

\section{ПОДХОДЫ К ИЗУЧЕНИЮ ЮРИДИЧЕСКОГО ДИСКУРСА В ЛИНГВИСТИКЕ}

\author{
Жуманиёзова Н. А. \\ Узбекский государственный \\ университет мировых языков
}

Аннотация: В данной статье частично обсуждаются подходы к изучению юридического дискурса в лингвистике и его основные особенности. Он также предоставляет несколько примеров, чтобы доказать его актуальность. Юридический дискурс - важная и актуальная исследовательская проблема, поскольку он является неотъемлемой частью современного общества. Многие работы в области лингвистики посвящены изучению этого понятия, и наша основная цель в этой статье - уделить больше внимания типам дискурса с их характеристиками, определению юридического дискурса и его функций, а также подходам.

Ключевые слова: Юридический дискурс, подходы, анализ дискурса, институциональный дискурс, функции, коммуникация, рамки

For a start, discourse or discourse analysis has been a contentious topic in linguistics so far as it still remains as an abstract notion. However, there are many views provided by lots of linguists and scholars in a bid to clarify this very term. In this article we mostly tried to write regarding the approaches to the legal discourse. Obviously, discourse is divided into two main categories by M.L. Makarov: colloquial and institutional [1, p.175] and he assesses the indicated types of discourse according to six criteria:

\begin{tabular}{|l|l|}
\hline \multicolumn{1}{|c|}{ Conversational discourse } & \multicolumn{1}{c|}{ Institutional discourse } \\
\hline process orientation & structure orientation \\
\hline minimum speech restrictions & maximum speech restrictions \\
\hline relatively free exchange of communicative roles & relatively fixed exchange of communicative roles \\
\hline greater conditioning by direct co-text & less conditioning by direct co-text \\
\hline primacy of local organization & primacy of a global organization \\
\hline $\begin{array}{l}\text { there are many goals, and they usually have a local } \\
\text { character }\end{array}$ & goals are few, and they are usually global in nature \\
\hline
\end{tabular}

When it comes to legal discourse, it is evident that it is one of the subtypes of institutional discourse and mainly refers to the acts of communication used in the realms of law. The functions of legal discourse are determined by the characteristics of law as a regulatory phenomenon. The main functions of the legal discourse entail prescriptive, informative, argumentative and declarative functions. The prescriptive function is presented in legal statements that directly or indirectly instruct the recipient to perform any actions or refrain from their commission. The informative function is contained in statements that report any fact that has occurred or a decision has been made.

Apart from that, several approaches to the study of legal discourse have been formed among which the following are distinguished: "sociolinguistic, pragmalinguistic and cognitive" [2, p. 5-7].

The first approach - the sociolinguistic one - focuses on the communication situation itself, the characteristics of communicants that are significant from the point of view of sociolinguistics, such 
as status, gender, age, education, ethnicity, etc. It follows from this that within the framework of the sociolinguistic approach, legal discourse is considered "as status-oriented" [3, p.5].

Karasik and Makarov state that the pragmalinguistic approach will make it possible to further develop the provisions of the socio-linguistic approach, since its purpose is to study the issues of using the language proper in the context of the judicial space. It deals with the study of legal discourse in terms of the linguistic means used in the communication process, as well as the intentions of the addressee and speech strategies. That is, locution, illocution and perlocution are studied.

The third approach - cognitive - examines legal discourse from the standpoint of mental images - frames that inevitably arise in the minds of communicants and their interpretation [4, p. 6]. These structures and methods of manipulating them are actively investigated within the framework of critical discourse analysis, which proves that the senders of a message deliberately use certain images in order to exert the desired effect on recipients.

In conclusion, there are several approaches to the study of legal discourse as institutional and presently topic is becoming one of the major issues in modern linguistics. Even though there is much research done in this field, it still requires the study towards the approaches of legal discourse.

\section{References}

1. Карасик, В. И. Языковой круг: личность, концепты, дискурс [Текст] / В. И. Карасик. Волгоград : Перемена, 2002. - 6 с.

2. Косоногова, О. В. Характеристики юридического дискурса: границы, содержание параметры [Текст] / О. В. Косоногова // Гуманитарные науки: Историческая и социально-образовательная мысль. - 2015 - Том 7, №1. - С. 61- 68.

3. Макаров, М. Л. Основы теории дискурса [Текст] / М. Л. Макаров. - М. : ИТДГК «Гнозис», 2003. -175 с. 


\title{
INNOVATIVE TECHNIQUES OF TEACHING ENGLISH TO NON-LINGUISTIC UNIVERSITY STUDENTS
}

\author{
Khalilova Himoyat Khatamovna \\ Tashkent Institute of Finance \\ A senior teacher of Uzbek and foreign \\ languages department
}

\begin{abstract}
Annotation: This articles examines the issues of teaching foreign languages in this case it is English, innovative methods and techniques of teaching English in ESP classes .It also discusses creation of multimedia apps and how to use them during the English classes.
\end{abstract}

Promoting foreign language teaching has been an important issue over the last several decades. And technological changes, Information and Communication Technology play a critical role in implementing resolutions in the field of teaching English as a foreign language (EFL). With the blossoming of the ICT as a new tool in language teaching, EFL and ESL teachers are expected to adopt a new view of integrating basic ICT skills in English classes appropriately. The application of ICT requires certain language skills and strategies. Introducing ICT into language classroom has great implications for curriculum reform, classroom teaching and student learning. It is believed that the increase of information and communication technologies (ICT) has dramatically reinforced and created powerful learning atmosphere. The implementation of ICT into real language context is more critical today than ever before since its growing power and capabilities are triggering a change in language learning environment. The integration of new ICT tools such as laptop, interactive whiteboard, LCD projector, internet and social networks in education support will help learners to use English in a very natural, real, communicative and stress free language learning environment. There are many multimedia technologies that are available for developers to create these innovative and interactive multimedia applications, such as Adobe Photoshop and Premier, Sound Forge and 3D Studio Max etc. The teacher uses multimedia to modify the contents of the material. It helps him/her to represent in a more meaningful way, using different media elements. These media elements can be converted into digital form, modified and customized for the final presentation.

They engage much more of the brain in the process of assimilating and connecting facts than conventional notes. The key notion behind mind mapping is that student learns and remembers more effectively by using the full range of visual and sensory tools at his/her disposal. Pictures, music, color, even touch and smell play a part in the learning armory, since it helps to recollect information for long time.

The sense of humor can also be an innovative teaching technique. Students always like lively and delightful personalities and that's natural. If one teaches whatever he/she wants in a humorous, delightful and entertaining way, he/she can easily achieve target. There are many devices with the help of which one can teach effectively. This method involves learning through delight. E.g. the games like word-antakshari, Spin-a-yarn, Role-Playings etc. are very effective in developing their linguistic competence. If this method is used properly, language learning becomes more interesting and easy.

Humor strengthens the relationship between student and teacher, reduces stress, makes a course more interesting and if relevant to the subject, may even enhance recall of the material. Humor has the ability to relax people, reduce stress and tension, and thereby create an atmosphere conducive for learning and communication. Numerous studies in the field of advertising have noted that humor is the most effective tool for enhancing recall of advertisements. It is easy to create a humor in the classroom by reading books of jokes and to listen to professional comics. The students should be encouraged to take notes, especially to learn about the professionals' use of such techniques as exaggeration, pauses, and timing. Observe reality and exaggerate it - much humor lies in observations about real life and truthful situations. In conclusion, humor not only plays an important role in the healing process but is also very important in education.

Another innovative teaching technique is the mnemonics words. Here the teacher is not supposed to talk on a particular concept for a quite long time. But to make it clear to the students he/she can just go on saying mnemonics or its associated meaning in words. Here he/she goes on saying only words instead of sentence, and once they come to a basic understanding of the meaning of a particular concept, then the teacher will explain in sentences. For example, in teaching language courses this 
technique can be used as an effective medium by the teacher to develop word power.

Moreover, role playing and scenario analysis is another innovative technique of teaching.

Science and engineering courses have practical but in support of those practical if students are given a scenario and other options to solve a particular issue, then the students are exposed to decision making in a given environment. One main advantage of role-playing is the possibility to encourage evaluation and synthesis of the subject matter, while practically taking students out of their chairs and allow them to learn it by doing. In addition it is the role of the teacher to explain for the students that it is not only fun, but an opportunity to participate in the learning process. In legal education it might be a court exercise, building up a negotiation strategy and observing a conclusion of a contract, or an alternative dispute resolution role-playing. They are appropriate to develop the argumentation and text analyzing and research skills of the students that they would need definitely in their professional life. Furthermore, student s can achieve deep-learning that is prerequisite of long-term knowledge.

From the above, we can make out that the Information and Communication

Technology has made many innovations in the field of teaching and also made a drastic change from the old paradigm of teaching and learning. In the new example of learning, the role of student is more important than teachers. The concepts of paperless and pen less classroom are emerging as an alternative to the old teaching learning method. Nowadays there is democratization of knowledge and the role of the teacher is changing to that of facilitator.

We need to have interactive teaching and this changing role of education is inevitable with the introduction of multimedia technology and the spawning of a technologically-savvy generation of youths. The analysis reveals some of the suggestions that the teaching community can practice in the classrooms. Ultimately the teaching people are satisfied when they could reach the students community with his their ideas and views. So, teaching depends upon successful mode of communication and Innovation, though we mean the changes that we propose to be included in our medium of communication or even inclusion of some other elements in communicating information.

\footnotetext{
References: 67 ,

1. Anthony Edward M. 'Approach, method and technique. English Language Teaching. -1963PP.65-

2. Dudley-Evans, T. Developments in English for Specific Purposes: A multi-disciplinary approach. Cambridge University Press, 1998.

3. Ellis, R. Task-based Language Learning and Teaching.- Oxford: Oxford University Press. 2003.
} 


\title{
THE USE OF INTERACTIVE TECHNOLOGIES IN TEACHING ENGLISH TO PART- TIME STUDENTS
}

\author{
Mukhabbat Mamadjanovna Kurbanova \\ teacher, Tashkent State Transport Univercity, Tashkent \\ Toshmurotov Umidjon Baydulla $0^{6} \mathrm{~g}^{6} \mathrm{li}$ \\ Student 2 course Tashkent State Transport university, Tashkent
}

\begin{abstract}
Annotation. The article substantiates the importance of introducing interactive teaching methods into the educational process. The main focus is on teaching English to part-time students. The author emphasizes that it is not enough for a teacher of the new generation to be competent in their field of knowledge; it is necessary to use methodological innovations in the educational process, which today are associated with the use of interactive teaching methods. The author considers a number of interactive methods, the implementation of which will contribute to the achievement of the set goal - increasing the efficiency of the educational process, achieving high performance by all students.

Key words: interactive methods, problem learning, discussion, training, "brainstorming".
\end{abstract}

At the present stage of development of society, knowledge of the English language becomes very important. There is no need to convince anyone of the need to learn a foreign language, life itself bears witness to this. TV programs are conducted in English, scientific literature is published, modern songs are played and foreign films are shown, in addition, instructions for various household appliances are written in English, etc. In most cases, if there is a translation, it is not always correct and therefore learning English is very relevant. But in order to make the process of language acquisition more effective, it is necessary to use interactive teaching methods. The introduction of interactive forms of education is one of the most important areas for improving the training of students in modern universities. It is not enough for a teacher of the new era to be competent in his field of knowledge; it is necessary to use methodological innovations in the educational process, which today are associated with the use of interactive teaching methods. Interactive learning is based on the direct interaction of students with their experience and the experience of their friends.

The purpose of interactive learning is to improve the efficiency of the educational process, in which all students achieve high learning outcomes. Let us consider this problem using the example of teaching part-time students a foreign language, in particular, English. All participants in the educational process interact with each other, exchange information, jointly solve problems and simulate the situation. The use of interactive forms of education when working with correspondence students has a number of advantages, namely:

- involvement of students in the learning process no longer as passive listeners, but as active participants;

- increasing the motivation of this category of students to study the subject; $\bullet$ mastering modern technical teaching aids;

- formation and development of skills of independent work on information search and productive use of the acquired knowledge in practice.

It should be noted that the educational process with correspondence students, based on the use of interactive technologies, aims to involve all students in the educational process, regardless of their level of language training. Collaboration means that all participants exchange information and ideas. In such a lesson, an atmosphere of free communication is created, which is characterized by cooperation between the participants in the educational process, equality of arguments, the accumulation of common knowledge, fair assessment and mutual control.

Consider a number of interactive teaching methods, the implementation of which will help achieve this goal - increasing the efficiency of the educational process and achieving results for all students.

Group discussions are usually held on a specific topic and are aimed at finding the right solution and achieving better mutual understanding. Group discussions contribute to a better assimilation of the studied material. At the first stage of the group discussion, correspondence students are given an assignment for a certain time, during which they must prepare a substantiated, detailed answer.

Training is a form of interactive learning, the purpose of which is to develop interpersonal skills and professional behavior in communication. The advantage of the training is that all participants are actively involved in the learning process. 
The teacher conducting the training must have psychological and pedagogical knowledge and be able to skillfully use it in the learning process, know the methods of obtaining information, collect and present it to the participants, influence their behavior and their relationships.

During the discussion, participants should discuss problems publicly or freely exchange knowledge, opinions, ideas on controversial issues. Its essential feature is the combination of dialogue-discussion and dispute-collision of different points of view and positions. Discussion is student-centered learning. It is characterized by active interaction of students with each other and intensive, person-centered learning on the part of the teacher.

During the discussion, participants should discuss problems publicly or freely exchange knowledge, opinions, ideas on controversial issues. Its essential feature is the combination of dialogue-discussion and dispute-collision of different points of view and positions. Discussion is student-centered learning. It is characterized by active interaction of students with each other and intensive, person-centered learning on the part of the teacher.

\section{Reference:}

1. Safonova L. Yu. Application of interactive forms of teaching. Methodical instructions. Velikie Luki, $2015.39 \mathrm{p}$.

2. Shaidarova OG Using interactive methods and techniques in teaching group communication in English // Foreign languages: linguistic and methodological aspects: interuniversity. Sat. scientific. works. Issue 33. Tver: Tver. state Univ., 2015, pp. 101-107. 


\title{
SOME FEATURES OF TEACHING SPECIAL VOCABULARY FOR NON- LINGUISTIC STUDENTS
}

\author{
Nigmatova Dilsoz Yadgarovna \\ a senior teacher \\ Tashkent Institute of Finance
}

\begin{abstract}
The article discusses the main features in teaching a foreign language for ESP students in a specific sphere. Significant issues related to teaching process in higher education system have been considered.
\end{abstract}

The importance of the role and place of specialists who speak one or more foreign languages is increasing due to the strengthening of international relations in the economic and socio-political fields. So, thanks to the knowledge of a foreign language, students can study foreign media, professional, fiction, communicate with foreign specialists, etc., supplementing their knowledge in professional and other fields. In addition, for modern and foreign companies conducting international activities, qualified employees with deep knowledge of one or several foreign languages are necessary.

Teaching a foreign language involves the formation of a general cultural foreign language competence, which includes communicative, cognitive, compensatory, intercultural and discursive components. For the successful formation of all these components, students need to know the vocabulary and grammar of the foreign language being studied. At the same time, vocabulary still plays an imperative role. The goal of teaching a foreign language is to be able to communicate in a foreign language. And, of course, the richer and more diverse a student's vocabulary, the more freely he will speak and express his thoughts in English. In this connection an emphasis should be placed on the methodology and tools for teaching vocabulary, in particular in a non-linguistic university.

Teaching foreign language vocabulary is a compulsory stage of the educational program in higher education and is carried out traditionally at the initial stages. Teaching should be based on an integrated approach, in other words, it is necessary to ensure the repetition of lexical material in lexicalgrammatical, phonetic exercises, tests, dialogues, creative and project tasks. However, at present according to some scientists' point of view, in modern textbooks in teaching a foreign language, the methodology of teaching vocabulary is not effective enough. When presenting lexical material, two techniques are used in most textbooks: students are either offered some word lists to memorize, or words have to be memorized as they appear in the exercises. But in both cases, the input dictionary is not systematized in the general list. This method, undoubtedly, cannot prevail in the system of teaching foreign language vocabulary, because the development of knowledge, skills and abilities in this area involves the use of a systematic approach. Unfortunately, in some modern textbooks, words are traditionally introduced that are not related to the topic being studied, they are rarely found in authentic texts, and therefore are little used. Accordingly, the teacher often has to correct the word lists, proactively build the educational process to meet the program requirements of the educational organization. The study of vocabulary by memorizing isolated words has another significant drawback: the studied word is correlated with one specific word of the native language; as a result, special attention is not paid to the peculiarities of the lexical system of the target language, which leads to interference and lexical errors in oral and written speech.

The following criteria are important for students of non-linguistic universities studying foreign language vocabulary:

- The teaching material should have a personal significance for the student and be used in speech statements about familiar topics of discussion, for example, in the context of a future professional sphere. This condition increases the motivational factor in learning a foreign language.

- In the process of teaching foreign language vocabulary, the student should act as a subject to determine the list of the most significant lexical units on the topic, their connections and mastery of them. In this context the student acts as the creator of his own "educational scope", regardless of the level of language proficiency.

- It is worth agreeing with the opinion of O.Yu. Digtyar [1] that incidental learning in the development of foreign language lexical knowledge is especially significant in formation of skills and abilities, as well as an increase in learning efforts to master service-structural and abstract (nonthematic) vocabulary. 
In addition to the main methods that are relevant for teaching foreign language vocabulary, among which are audiovisual, audiolingual ("a method of teaching a language that involves repeated listening to audio recordings and pronouncing language structures and speech patterns, which leads to their automation" the methods of the suggestive group become relevant. Suggestopedic teaching method is "a system of introduction and consolidation of speech material in communication situations that imitate the natural speech environment, as well as the activation of students during the educational process and the mobilization of their hidden psychological reserves . In this context, active (innovative) methods are interesting and practically significant.

Considering above-mentioned suggestions, it can be noted that playful and illustrative-explanatory methods can be actual active methods of teaching foreign language vocabulary for students of non-linguistic specialties. So, active game exercises for mastering and (or) improving every day or professional foreign language terminology, contributing to more effective memorization of not only specific scientific terms, but also their meaning with the mandatory use of an audiovisual approach (for example, through an interactive whiteboard, the Videotext program, etc.)

From the point of view of L.G. Karandeeva, the play method has a high practical potential, since, for example, all those actions, attitudes and intentions that are components of translation activity can be incorporated into the scenario of a role-playing game. The method under consideration gives nonlinguistic students the opportunity to explore, understand and acquire practical skills that can greatly facilitate future professional communication. In addition, the creative nature of games allows you to create a learning language environment, including all participants in the educational process in its space, while promoting creative search, self-expression, and self-development of students.

The most successful way in teaching specialists in a certain sphere is through linguistic corpora. Thus, Corpus of Contemporary American English (COCA) is recognized as one of the largest corpuses of the English language. It is the only large corpus of American English with 445 million tokens. It contains in equal proportions oral speech, fiction, magazine articles, newspapers, scientific texts.

In this system, a special role is given to teaching foreign language vocabulary. As a result, teaching foreign language vocabulary is a formed set of lexical knowledge, skills and abilities of their use in various contexts, as well as a strategy and tactics for mastering lexical material. In order to obtain an effective result, it is advisable to focus on the methodology and teaching tools. Words and combinations that are often used by native speakers, learned by students in the process of research activities, become meaningful for students and form their lexical and grammatical skills. Also, research activities develop cognitive skills and the ability to independently and correctly use the language.

\section{References:}

1. Digtyar O.Yu. Organization of lexical material and its assimilation as a factor that co-determines the effectiveness of teaching a foreign language, 2009, p. 23.

2. Lebedinsky S.I., Herbik L.F. Methods of teaching Russian as a foreign language. Tutorial. Minsk, 2011, p. 309.

3. Karandeeva L.G. Development of translation competence based on the role-playing method, Terms of pedagogical practice, 2018, pp. 14-21.

4. Mohova O.L., Nazarova N.B., Sokolovskaya M.A., Basherov O.I. Teaching Foreign Language Vocabulary in a Non-Language University, Modern problems of science and education, 2019, No. 2. pp. 1-11. 


\author{
Nurboboeva Asila Kenjayor qizi \\ $4^{\text {th }}$ course student of Karshi State University, \\ Faculty of Foreign Languages, \\ Supervisor: Holiqova Husnora \\ Contact number +998912574002 \\ e-mail: gulnozaqurbonova@mail.ru
}

\begin{abstract}
Annotation: A polite, knowledgeable, hard-working, faithful child is the greatest wealth not only of a parent, but of the whole society. Indeed, every child is formed in an individual family. So the family is the foundation of a harmoniously developed generation. Therefore, the moral and legal upbringing of children in the family, especially the formation of justice, duty, patriotism, awakening a sense of love for the motherland is very important.
\end{abstract}

Key words: knowledge, parents, education, primary education, family.

This is the basis for a sincere relationship between parents, close and friendly relations with their children, understanding of their future dreams and goals, the healthy development of children. A person has good behavior, habits and intelligence in the process of upbringing. if he has, he understands life lessons so well and does good deeds, and conversely, the less educated he is, the less life skills he has, the more he sometimes commits bad deeds, knowingly or unknowingly.

We must never lose sight of the mistakes we make in raising children. In our present life, there are some people who are rude, ignorant, stupid, addicted, addicted to their parents and causing their children to live unhappily. Is it their parents who are to blame? Their human behavior was caused by their indifference to upbringing.

Good parenting is not an hour or a day's work, as some think. Targeted upbringing requires endurance, perseverance, great knowledge and experience from the educator. This means that every parent and teacher must have the knowledge and skills related to upbringing. In order to quickly achieve positive results in the upbringing of children, it is desirable to educate them, to involve them in certain labor processes, to teach them the secrets of profession and specialty. One of the main reasons why educational work is sometimes ineffective is the lack of discipline in the educational process. The more a person is brought up on the basis of love and discipline, the farther away from bad behavior actions will be. The main purpose of upbringing is to bring up young people as happy, dear, respected and selfless people of their time. The complexity of upbringing is that it never ends, that is, it is necessary from birth to death. In addition, it is necessary to re-educate the children who replaced one generation. This shows the relentless periodicity and eternity of upbringing.

According to Islamic teachings, a child is a deposit in the hands of the parents, who are responsible for that deposit. Neglecting the upbringing of children is a huge mistake, a betrayal of trust and a shortcoming of one's religion. Parents are the first guardians of their children. In the Qur'an, Allah states how much attention is needed to the family:

"O you who believe, guard yourselves and your families from a Fire whose fuel is men and stones, over which are angels who are stern and steadfast, and do not disobey what Allah has commanded them, but do what they are commanded." (Tahrim, 6) how upbringing, especially counseling, begins in the family.

The main purpose of education is to bring up people who love each other. Parents should not forget that today a person who does not pay attention to the upbringing of their children will be left homeless and familyless years later. Abu Hamid al-Ghazali says the following about parenting: "Know! Raising a child is one of the most important things. The child is entrusted to the father and mother. The child's heart is pure, delicate, simple and a jewel free from any patterns and images. It is formed according to the pattern in which it is placed, it bends in the direction of the bend.

If a child learns goodness and grows up in goodness, he will find happiness in this world and in the hereafter. Of course, his parents, teachers and everyone who brought him up share in this blessing. If a child is neglected, grows up in evil, he will suffer misery and perish. In this case, the burden of guilt falls on those who put it, the parents. "In this regard, Allah warns in Surat at-Tahrim: "O you who believe, protect yourselves and your families from the Fire."

There are two foundations of discipline: good morals that protect virtue and vigilance that protects 
one from the evil path, from bad behavior. The more a father protects his child from the fire of this world, the more he must protect him from the fire of the hereafter. Through etiquette, a father protects his child from the fire of the Hereafter by teaching him good manners, forbidding him from evil, not accustoming him to luxury, and not arousing love for adornment. The earlier a child's upbringing begins, the more effective the parenting outcome will be. Because it is easy to turn them to good at an early age.

Bad behaviors and habits that result from ignorance can be corrected by later re-education. But it takes a lot of work.

Morality is the fear of every human being. Etiquette (plurality of Arabic etiquette) is a socially recognized norm of behavior. Etiquette reflects the appearance of one's spiritual life and is reflected in one's relationships with others (family, various ceremonies, work community). It includes aesthetic education, such as how a decent person should behave in public, how he should treat people, how he should organize his life, his leisure time, and what he should look like (modesty, humility, kindness, cleanliness). Man's manners show how he was brought up.

\section{Used literature:}

1. Collection of settled works. Tashkent, 1960.

2. Tursunov H, Yerbayev B., Aliev A. History of Uzbek literary language. Tashkent, 1995.

3. Karimov G.K. History of Uzbek literature. Tashkent, 1987. 


\title{
LECTURER AT THE DEPARTMENT OF UZBEK LANGUAGE AND LITERATURE
}

\author{
Nuritdinova Rayhona Numonovna \\ Fergana State University, Faculty of Philology
}

\begin{abstract}
Annotatation: The article examines the emergence of the science of sociolinguistics, role in the area of linguistics. About the researchers who contributed to the development of science and their scientific activities.
\end{abstract}

Key words: sociolinguistics, social conditions, external factors, language, parole, blingvism, multilingualism

The term "sociolinguistics" was first used in 1952 by the American sociologist Herman Kerry. However, sociolinguistics as a science in the early 1950 year not formed. The origin of this science goes back to antiquity, and its basis can be traced back to European and Russian linguistics.

The most important components of modern sociolinguistics in the first half of the twentieth century were I.A. Baudouin de Courtenay, E. Polivanov, L. Yakubinsky, V. Zhirmunsky, B.M. Selishchev, V.V. Vinogradov, G. OB. Distiller; Francades F. Bruno, A. Mee, P. Lafargue; Switzerland S. Bally and A. Sesche; J. Vandrislar, Belgium; B. Havranek, Czechoslovakia; We see this in the study by A. Matezius et al.

The famous Russian linguist I.A. Baudouin de Courtenay was "one of the first to introduce the study of language as a living human language" [1]. At the same time, he argued that the language must be study live, as well as the human factors that generate it. As a result, the human factor itself demanded a sociological approach to language.

We see that many scholars in the field of world linguistics have taken the sociological aspect of language as the main condition in their research. In particular, the approach of the German scientist Schleicher to language as an organism also had a certain social dimension. These were his ideas, developed by I. A. Baudouin de Courtenay, who called the term "organism" "a function of the organism" and explained it as follows: "Language is ... a means arising from the activity of organs." [2]. In the quoted passage of the scientific text, we see how much attention is paid to the social function of language. Since language is a spoken member of a person, it is thanks to this person that it arises, develops and improves. In particular, I. A. Baudouin de Courtenay began to analyze its phonetic structure, walking among these people to study the Slavic language[3]. Develops transcription system independently. The famous Russian scientist L. V. Sherba assessing the work of Baudouin de Courtenay and states: "... he was one of the first to practice phonetics with his own understanding"'[4].

Baudouin de Courtenay achieves this goal in this way, taking into account not only the «pure side» of the language, but also the «external» factors. [5].

From all of the above, it follows that non-linguistic factors are precisely the social and psychological factors of the language.

The scientific study of linguistic phenomena in connection with social phenomena began to be observed in countries such as France, Russia and the Czech Republic at the beginning of the twentieth century. The language institutes of these countries study the language without sharply separating it from "pure" linguistics. In general, such views can be observed not only in Russian linguistics, but also in European linguistics. First of all, F. de Saussure's views can be a prime example of this. U language and speech (parole) and speech activity (language).

\section{Reference}

1. I.Los. Bauduen de Kurtene. «Encyclopedic dictionary Brokgauza - Efrona», t. IV., 1894, p. 222.

2. «August Schleicher» see orign publish t I, p. 38

3. V.V.Vinogradov.I.A.Bauduen de Kurtene https://danefae.org/lib/vvv/baudouin.htm

4. «Некоторые общие замечания о языковедении и языке». См. наст. изд., т. I, стр. 136

5. Связь фонетики и морфологии языка. - изд. Наука., Варшава, т. I, 1908, стр.10

6. Звегинцев В.А. «История языкознания XIX и XX веков в очерках и извлечениях.» Часть 1. M., 1960. www.slovesnik.ru 


\title{
PRINCIPLES OF COGNITIVE METAPHOR AND ALLEGORY IN DISCOURSE.
}

\author{
Rajapova Malika Ahmadali qizi, \\ a teacher of Kokand state pedagogical institute \\ Hamdamova Mohidil To'xtasinovna, \\ a teacher of school №25, Dang'ara region \\ Email: malikarajapova1993@gmail.com \\ Phone number: +99891 1501014 ; +998912054169
}

\begin{abstract}
Annotation: This article describes the functions of allegory and metaphor in cognitive linguistics. It gives useful information about allegory and metaphor, their similarities and differences as well as usage of them.
\end{abstract}

Key words: cognitive linguistics, cognitive grammar, cognitive linguistics, transference of meaning, derivative meaning

Cognitive Linguistics is a new branch of linguistics. Cognitive linguistics studies relationship between language and mind; it views the process of producing speech as a cognitive, psychological process. The term "Cognitive Grammar" has two meanings. In wide sense Cognitive Grammar is synonymous with Cognitive Linguistics as it views language phenomena in their connection to cognitive processes such as memory, perception, attention and thinking. In a narrow sense Cognitive Grammar is a direction of Cognitive Linguistics. Great linguists Talmy and Langacker can be defined as the most famous researchers in the field of Cognitive Grammar. Talmy argued that grammar categories specify cognitive ones. Grammatical category of number is subdivided into "singular", "dual", "plural", while cognitive category will continue this classification to: "even", "odd", "dozen" or "numerable". While talking about "Cognitive Grammar" it is important to say that the term "Grammar" is used in its broad sense and it refers to the whole language system, including sound, meaning and morph syntax. From this point of view grammar is considered to be a symbolic phenomenon (Langacker).

The stylistic device based on the principle of identification of two objects is called a metaphor. The term "metaphor", as the etymology of the word reveal means transference of some quality from one object to another. From the times of ancient Greek and Roman rhetoric, the term has been known to denote the transference of meaning from one word to another. It is still widely used to designate the process in which a word acquires a derivative meaning. Quintilian remarks: It is due to the metaphor that each thing seems to have its name in language. "Language as a whole has been figuratively defined as a dictionary of faded metaphors. Thus by transference of meaning the words grasp, get and see come to have the derivative meaning of understand. When these words are used with that meaning we can only register the derivative meaning existing in the semantic structures of the words. Metaphor is a stylistic device that can add artistic color to any kind of text, make it attractive and explain it more clearly to the speech receiver.

Allegory is a form of symbolism in which a symbolic word is used instead of an abstract concept of an event or thing to express a clear image, that is, a way of expressing in a literary work a concept that is vague to the reader with familiar features. An allegory also expresses an abstract concept or idea through a clear image. For example, the word "wolf" means evil, wickedness; the use of the word "fox" as a metaphor is one of the first examples of allegory.

Allegory is also a form of art in which an image or story can convey the idea conveyed to the reader through the use of various symbols. Some linguists consider that allegory to be an extended form of metaphor. However, some of them interpret allegory and metaphor as different stylistic devices. Because if an allegory is used as a means of artistic imagery, a writer can use an allegory to express an event or message based on moral, educational, political, historical, and so on. An allegory is a story within a story. It has a "surface story" and another story hidden in it. For example, the surface story might be about two neighbors throwing rocks at each other's homes, but the hidden story would be about war between countries. Some allegories are very subtle, while others (like the rock-throwing example) can be more obvious. In most allegories, the hidden story has something to do with politics, religion, or morality - complex subjects that are difficult to understand directly. Many authors find it easier to think through these issues by translating them into allegories, which are easier to understand and more fun to read than dense philosophical arguments. Allegories deliver difficult messages in 
easy-to-read stories. That makes them extremely useful and expressive tools. So for centuries, human beings have used allegories to say things they couldn't say any other way. Some scholars believe that myths and religious stories originated as allegories for the deep secrets of the universe and the human mind - secrets that humans cannot comprehend without the help of an allegorical story. On this interpretation, the allegory is the oldest form of story in the world. People often use allegories in order to understand the world around them whether it's the world of politics, new technology, or the many ethical problems that challenge us today. Thus we can see a peculiar connection and a peculiar difference between the allegory and the metaphor. Connection is that both stylistic devices are used to convey easily the abstract concept in the text to the listener in an interesting way.

\section{Used literatures:}

1. Galperin I. R. "Stylistics" Moskva. 1995

2. Oxford Advanced Learners' Dictionary of Current English. Oxford Press. 2005

3. Roger Perez. Conceptual metaphor theory and Sartre's philosophy. Universitat Autonoma de Barcelona. Department de Filologiya Catalona. 2001.

4. Boboxoxnova L. T. "Ingliz tili stilistikasi” Toshkent, O'qituvchi. 1995

5. Znamenskaya. Stylistics of the English language. Москва 2004 


\title{
CHET TILLARINI O`QITISHDA ZAMONAVIY TEXNOLOGIYALAR.
}

Sattorova M

Toshkent moliya institute $\mathrm{O}^{`} z$ zek va xorijiy tillar kafedrasi katta' o'qituvchisi

\begin{abstract}
Annotation : This article discusses the important features of teaching foreign languages nowadays, issues and resolutions concerning this topic, their implementation and the role of information communication technologies in teaching foreign languages.
\end{abstract}

Bugungi kunda xorijiy tilni bilish o"ta muhim ahamiyat kasb etayotganligi bois chet tili o"qitish tizimini ham isloh etish, dars jarayonlarida zamonaviy pedagogik va axborot-kommunikatsiya texnologiyalaridan foydalangan holda o'qitishning ilg'or usullarini qo'llash ta'lim tizimidagi dolzarb masalalardan biriga aylandi. O‘zbekiston Respublikasi Prezidenti Islom Karimovning 2012-yil 10-dekabrda PQ-1875 sonli «Chet tillarni o'rganish tizimini yanada takomillashtirish chora-tadbirlari to 'g'risida»gi Qarori chet tili ta'limini rivojlantirish, o'sib kelayotgan yosh avlodni zamon ta lablariga mos yetuk mutaxassis etib tayyorlash kabi ezgu- maqsadlarga yo"naltirilganligi bilan alohida ahamiyat kasb etadi. Mazkur Qarorning ahamiyatli jihati shundaki, unda ta'lim tizimining barcha bosqichlarida chet tillarni uzluksiz o'rganishni tashkil q ilish, shuningdek, o'qituvchilar malakasini oshirish hamda zamonaviy o'quv-uslubiy manbalar bilan ta'minlashni yanada takomillashtirish, zamonaviy pedagogik va axborot-kommunikatsiya texnologiyalaridan foydalangan holda o'qitishning ilg'or uslublarini joriy etish, o'sib kelayotgan yosh avlodning chet tillarga bo'lgan qiziqishini yanada oshirish va $0^{6} z$ navbatida, chet tillarda erkin so'zlasha oladigan mutaxassislarni tayyorlash tizimini tubdan takomillashtirish, shu bilan bir qatorda, ularning jahon sivilizatsiyasi yutuqlari hamda jahon axborot resurslaridan keng ko 'lamda foydalanishlari, xalqaro hamkorlik va muloqotni ivojlantirishlari uchun sharoit va imkoniyatlar yaratish ko'zda tutildi.

Demak, o'qituvchi, yangi pedagogik texnologiyalar, nazariyalar, konsepsiyalar muallifi, tadqiqotchi, foydalanuvchi va targ'ibotchi sifatida namoyon bo'ladi. O'qituvchi innovatsion faoliyatining tahlili yangilik kiritishning samarasini belgilovchi muayan me'yorlardan foydalanishni talab qiladi. Bunday me'yorlarga yangilik, optimallik, natijalilik, ommaviy tajribalarda innovatsion ijodiy qo'llash imkoniyatlari kiradi. Bugungi kunda ta'lim jarayonida texnik vositalardan foydalanish juda muhim o'rinni egallaydi. Ushbu vositalar yordamida mashg'ulotlarni zamonaviy talablarga javob beradigan tarzda olib borish hamda ta'lim oluvchilarning diqqatini jalb etishda keng foydalanish mumkin.Ta'lim beruvchi texnika vositalari, yani kompyuterlar, yangi elektron darsliklar, internet tizimi,o'quv va o'quv-uslubiy qo'llanmalar va boshqa vositalar o'quv axborotini o'zlashtirilishi kerak bo'lgan ma'lumotlarni ta'lim oluvchilarga yetkazib beruvchi texnik vositalardir. Axborot beruvchi texnika vositalariga turli elektromexanik asboblar, mashg'ulotda ko'rgazmali tasvirlarni ko'rsatishga mo'ljallangan demonstratsion ossillograflar va ularning asboblari, shuningdek, televizor, videoproyektor, smartfon mobil aloqa vositalari, tovushli multimedia texnologiyalari va boshqa vositalar kiradi. Ular talabalar savodxonligini oshirish, nutqini o'stirish, aqliy qobiliyatini rivojlantirish, mantiqiy fikrini takomillashtirish, ijodiy fikrlay olish hamda ta'lim tizimlari orasidagi uzviylikni ta'minlashga qaratilgan.

Ma'lumki, ta'lim jarayonini kompyuterlashtirish nafaqat ta'limiy axborotlarning yaxshi, balki yangi axborot texnologiyalari elementlarini ham o'zlashtirilishiga yo'naltiriladi. Ayniqsa, chet tillarini o'rganishda kompyuterlar o'qituvchining mehnatini osonlashtirib, dars jarayoni samaradorligini oshirishini alohida ta'kidlash zarur. Yaxshi multimediyali dasturlar maqsadga yo'naltirilishi zarur, shu sababli o'quv materiali aniq bir mavzuni yorita olishi, dastur o'quv jarayonining barcha komponentlarini qamrab olishi shart.

Zamonaviy kompyuter auditoriya mashg'ulotlari davrida eng qulay texnik vosita hisoblanadi. Chet tili darsi jarayonida zamonaviy pedagogik texnologiyalardan unumli foydalanish, talabaning tilga bo'lgan qiziqishini yanada oshirish va ularning tildan egallaydigan bilim, ko'nikma va malakalarini yuqori bo'lishini ta'minlaydi. Shuning uchun chet tillar ta'limida quyidagi turli xil yangi pedagogik texnologiyalardan foydalanish nazarda tutiladi:

- kompyuter texnologiyasi ;

- test topshiriqlarini kompyuter orqali amalga oshirish, elektron xabarlar, elektron darslik, o'quv qo'llanmalar, lug'atlar yaratish; 
- chet tilparni o'qitishda Internet yordamida bevosita masofaviy ta'limdan foydalanish;

- til materiali, nutqiy malaka va ko'nikmalarni shakllantirishga tabaqali yondashish;

- talabalarning o'quv faoliyatini, mustaqil ishlarini tabakali tashkil etish hamda kompyuterli nazoratni tashkillashtirish;

- texnik vositalar(video, audiomagnitafon, proyektorlar)dan foydalanish;

- ko'rgazmali qurollardan foydalanish:

- texnik vositalar yordamida dars mavzulari bo 'yicha taqdimotnomalarni yoritish.

Bugungi kunda kompyuter va uning tarkibiga kiruvchi texnik vositalar mavjudligi, shuningdek, yangi multimediya tizimidan to 'g'ri foydalangan holda ta'lim tizimida o'quv jarayonini, ayniqsa, chet tilini o'qitish mashg'ulotlarini tashkil etish imkoniyati vujudga keldi. Interaktiv metodlar: suhbat, loyiha metodi, aqliy hujum, diskussiya, klaster metodi, Case metodi, rolli uyinlar, juft bo'lib ishlash, musobaqa, ko'rik -tanlovlar, Jigso metodi, davra suhbatlari, ko llokvium, muammoli o'qitish va boshqalar. Agar chet tillarni o'rgatishda kasbiy yondashilsa, masalan talabalar bilan chet til amaliy darslari olib borilganda quyidagi ayrim metodlarni qo "llashni amaliy misollar orqali yoritib beriladi.

- Klaster metodi - bu tarmoqlarga bo'lish metodi bo'lib, bunda o'qituvchi tomonidan tanlangan mavzu qamrab oladigan barcha yo"nalishlar talabalar ishtirokida yoritiladi. Bu metodni quyidagi tarzda amalga oshiramiz. Masalan: «Hotels of Uzbekistan» matni auditoriyada noutbuk orqali eshittiriladi, ko'nikma hosil qilish uchun klaster usulidan foydalanamiz. Undagi berilgan yo"nalishlar umumlashtirilib, asosiy hikoya tuziladi. Natijada talaba ushbu mavzu haqida ko"nikma hosil qiladi.

- «Debating», «Discussion» (munozara, muhokama qilish) usulida guruh talabalari 2 jamoaga bo'linadi. O'qituvchi tomonidan proyektor yordamida dars mavzusi bo'yicha savollar ekranda ko'rsatiladi va ikki jamoa a'zolari mavzu bo'yicha javob berib, o'z-fikr mulohazalarini bildiradi. O'qituvchi berilgan javoblarni to'g'ri yoki noto'g'ri ekanligini aniqlab beradi va qaysi jamoa g'olibligini e'lon qiladi. Bu usul chet tilni o'rganishda so'z boyligini oshirish, fikrni mustaqil bayon etish malakasini oshiradi.

- «Work in pairs» (juft bo'lib ishlash) usulida 2tadan talaba tanlanib, mavzu beriladi. Namuna sifatida dars mavzusiga birorta suhbat (dialog) texnik vositalar yordamida eshittiriladi. Talabalar tomonidan berilgan mavzu asosida suhbat (dialog) tuziladi. Bu usul talabalarni mustaqil ishlashga undaydi va og'zaki nutqmalaka va ko'nikmalarini shakllantiradi.

"Chet tillarni o'rganish tizimini yanada takomillashtirish chora-tadbirlari to'g'risida»gi Qarorda ta'lim muassasalarida xorijiy tillar o'quv xonalarini zamonaviy axborot kommunikatsiya va o'qitishning texnik vositalari va anjomlari bilan jihozlashning jadallashtirilgan dasturini ishlab chiqish talabi ilgari surilgan. Ta'lim-tarbiyaga bo'lgan hukumatimiz e'tiborini kuchayishi, ushbu sohaning har bir vakilini yanada izlanishga, o'z kasbiga sidqidildan yondashishga undaydi.

\section{Qo'llanilgan adabiyotlar:}

1. Saydaliyev S. Chet til o'qitish metodikasidan ocherklar.-N., 2004.

2. Yangi pedagigik texnologiya:tahlil, ta'rif, mulohazalar: Maqolalar to'plami.-T., 2010. 


\title{
CHET TILLARNI O`QITISHDA INNOVATSION TEXNOLOGIYALARDAN FOYDALANISH
}

Shodmonbekova K

Toshkent moliya institute $\mathrm{O}^{`} z$ zbek va xorijiy tillar kafedrasi katta`o'qituvchisi

\begin{abstract}
Annotation: New methods and techniqus of information technologies and their usage during the language lessons are described in this article. This article also examines new system in teaching sphere and implementation of information technologies into the educational system.
\end{abstract}

Til o'rgatish va o'rganish o'ziga xos murakkab jarayon. u bir-biriga uzviy bog'liq bo'lgan bir necha jihatlarni o'z ichaga oladi. Bu jarayon eshitish, anglash va nutqdan iborat. albatta nutq bu to 'la ma'nodagi fikr anglatish bo'lmay, xatolardan holi bo'lmagan, gramatik qoidalarga to'la to'kis javob bermaydigan so'zlar tizimi ham bo 'lishi mumkin. Ta'lim sifatini yaxshilash, talabalarning intelektual pedagokikaning asosiy vasifasi hisoblanadi

Inteluktual faollikni oshirishda interfaol usullaridan foydalanish yahshi samara beradi.Interfaol usullari esa o"zaro harakat yoki hamkorlik asosidagi harakatni bildiradi.Mazkur usulning bir qancha turlari mavjud: "Fikriy hujum", "Sinektika", "Mojaro", "Dumaloq stol”, "Uch bosqichli interviyu" "Qor bo'ron"va boshqa usullari kiradi.

Dars qiziqarli o tishi uchun shu usullardan foydalanish kerak. shulardan ayrimlari bilan tarnishing.

"Dumaloq stol" usuli. Topshiriq yozib qo'yilgan qog'oz varag'i davra bo 'ylab aylantiriladi. Har bir talaba o'zining javob variantini yozib qo'ygach, varaqni boshqa talabaga uzatadi. Keyin muhokama bo'ladi. Noto'g'ri javoblar o'chiriladi, to'g'ri javoblarga qarab talabaning bilimiga baho beriladi. $\mathrm{Bu}$ usulni faqat yozma shakilda emas og'zaki shakilda ham qo'llash mumkin.

"Ruchka stol o'rtasida" usuli. Butun guruhga topshiriq beriladi. Har bir talaba bitta javob variantini bir varaq qog'ozga yozib, uniqo'shnisiga beradi, o'z ruchkasini esa stolning o'rtasiga surib qo'yadi. O'qituvchi guruhga topshiriq beradi. $10-15$ daqiqa ichida guruh mumkin qadar ko'proq sonda javab variantlarini berishi kerak. Bir varaq qog'ozga ozilgan topshirish bir talabadan ikkinchisiga uzatiladi. Yangi asr bo'sag'asida turgan amlakatimizda chuqur, keng qamrovli iqtisodiy, siyosiy, ijtimoiy islohotlar amalga oshirilmoqda. Shunday ekan yosh avlodni tarbiyalash va ularga mustahkam bilim berish har bir o'qituvchining oldida turgan vazifadir. Bundan tashqari talabalar bilim saviyasini o'stirishda darslarda turli interfaol usullardan foydalanish uchun o'qituvchi doim izlanishda bo'lishi kerak. Darslarni qanday qilsak qiziqroq va samaraliroq o'tishi har bir o'qituvchi boshini qotiradigan masaladir.

Birinchi kurslarda ko'proq "True and False" (to'g'ri va noto'g'ri) metodikasi tarzida o'tkazish mumkin. Pedagogik texnologiya aslida insonlarni tarbiyalash vositasi sifatida azaldan mavjuddir. "Texnologiya" so"zi 1872 yilda fanga kirib kelgan va yunoncha "texnos"-hunar,"logos"- fan degan ma'noni bildiradi.

"Pedagog” esa boshqaruvchi, yetaklovchi degan ma'nodan olingan. Demak, pedagogik texnologiya o'qituvchi tomonidan boshqariladigan ta'limtarbiya jarayoni ekan. Uning samarasi esa o'qituvchining pedagogik mahoratiga bog 'liq. Innovatsion texnologiyalar ta'lim sohasida yangi soha, "Innovatsiya" degan so 'zning o'zi ham "yangilik", "yangilik olib kelish" degan ma'noni anglatadi. Zamonaviy yangi pedagogik texnologiyalarning kirib kelishi ananaviy pedagogikani hech qachon butunlay yo"qqa chiqarmaydi. Uning imkoniyatlaridan keng foydalanilyapti. Usulning asosiy qoidalariga amal qilish vaziyati eng ma'qul yechimini topishga, muloqot olib borish himoya qilinyotgan usul talabalarni $\mathrm{O}^{6} \mathrm{z}$ nuqtai nazaridan isbotlash, himoya qilish, har qanday nuqtai nazarning to'g'riligiga hammani ishontirishga o'rgatadi. Usulning maqsadi guruhdan qisqa vaqt ichida ko'p miqdor variantlarni olish, talabalar nimalarni bilishini aniqlash. Mashg'ulot davomida muammoni hal eta oladigan g'oyalar taklif etilishi, umumiy tajriba yuzasidan firk almashish uchun zamin yaratilishi va talabalar $0^{6} \mathrm{z}$ istaklarini bildirishi mumkin. $\mathrm{Bu}$ jarayon mohiyati shundan iboratki, guruhga mavzu, savol yoki tugallanmagan taklif beriladi. Guruh azolari bir necha daqiqa davomida shu mavzu yuzasidan gaplashib, qanday fikr kelsa, shularni hammasini aytishadi va bularning hammasini tinglash, bo' $r$ bilan doskaga yoki daftarga yozib berish tavsiya etiladi. Gaplarning hammasi, ular qanchalik noaniq, bemani yoki bahsli bo'lmasin yozib qo'yilaveradi. Hamma o'z fikrini muhokama qilmasdan turib, bayon qiladi, chunki maqsad ko'proq miqdorda va hilma - hil takliflar olishdir. Bu paytda hech 
qanday ta'qiqlar bo'Imaydi. Qatnashuvchilarda takliflarni taxlil qilish, norozilik bildirish va taklif etilgan hamma fikrlarni muhokama qilib sust bo'lsa o'qituvchi o'z fikrlaridan ba'zilarini yozib olishni taklif etishi mumkin. Ishlab chiqarish ta'lim jarayonining eng muhim jihatdan biri ta'lim metodlari dir. Ishlab chiqarish ta'limi metodlari deganda, ustoz va o'quvchilarning birgalikda tashkil etilgan faoliyatining shunday usullari tushuniladiki, ularning yordamida o'quvchilar amaliy bilimlarni, ko'nikma va bilimlarni egallaydilar, ularning kasbiy mahorati, mehnatga munosabat asoslari shakillantiriladi, aqliy va jismoniy kuchlar, ijodiy qobilyatini rivojlantiradi. Bunda o'qituvchining vazifasi- ta'lim olayatganlarning fanga bo'lgan qiziqishini yanada oshirish, ularda mustaqil ta'lim olish malakasini shakillantirish va aqliy salohiyatini ortishini taminlash, ularni nostandart masalalarni yechish davomida ta'lim oluvchiga ko'maklashish, uning yo'l qo'ygan samarali o'qitishni tanlash kabi vazifalarni bajarishda qo'llanadi. Ta'limni tashkil etishdagi yangicha yondashuvlar quydagi hollarda namoyon bo'ladi.

- ta'lim muassalarida o'qitishni tashkil etish bo'yicha yangi inno vatsion texnologiyalarga asoslangan maqsadga yo'naltirilgan siyosat olib borish; ta'lim muassalarida ta'limning yangi innovatsion texnologiyalarga asoslangan tarmoqlarini rivojlantirish. Ta'lim muassalarida amalga oshirilayotgan masofadan o'qitish YaIT ga misol bo'la oladi.

Hozirgi vaqtda ta'limning yangi tashkiliy tuzilmalari, uning yangi turi va shakllari davlat va nodavlat ta'lim muassalarida paydo bo 'lmoqda. Dunyoning qator mamlakatlarida qator zamonaviy nodavlat gumanitar universitetlar, o'qitishning yangi shakllari ta'limni boshqarishning yangi tamoillari asosida faoliyat ko'rsatmoqdalar. Ta'limning boshqarishning yangi mexanizimi, ta'lim sohasida komputerlar va telekommunikatsion texnologiyalardan foydalanish texnologik innovatsiyalarni o'zlashtirish yaxshi samara beradi. O'zbekistonda iqtisodiy islohotlar jarayonlari tezkor rivojlanish dinamikasi ta'lim tizimi oldida ijodkorlik va tashabbuskorlik qobilyatiga ega, mustaqil qaror qabul qila oladigan va texnik ehnologiyalarga tez moslashishga layoqatli, malakali mutahasislarni tayyorlash vazifasini qo'yadi. Shuningdek, oily va kasb-hunar tizimi oldida turgan dolzarb biri o'qitishda zamonaviy pedagigik texnologiyalar va yutuqlardan keng foydalanish, ularni o'quv jarayoniga joriy qilib borish muhim hisoblanadi. Zamonaviy ped agogik taxnalogiyaning maqsadi-ommaviy ta'lim sharoitida ta'lim jarayonining zaruriy samaradorligini ta'minlash va talablar tomonidan o'qishning ko'zlangan natijalariga erishish kafolatidan biridir. Mazkur jarayonda mantiqiy fikrlash, tasavvur qilish bilish faoliyatini rivojlantirish kabi jihatlar muhim ahamiyatga ega. Hozirgi vaqtda mutahassislarning nazariy bilimi va kasbiy tayyorgarligiga, zamonaviy axborot va pedagogic texnologiyaldan foydalanishga bo'lgan talab keskin ortmoqda. Shu maqsaddan kelib chiqqan holda ta;lim muassalarning resurs, kadrlar va axborot bazalarini yanada mustahkamlash hamda o'quv tarbiya jarayonini, zamonaviy pedagogic texnologiyalar bilan yo'liq taminlash vazifalari belgilab qo‘yilgan.

\section{Qo'Ilanilgan adabiyotlar:}

1. Saydaliyev S. Chet til o'qitish metodikasidan ocherklar.-N., 2004.

2. Informatsion pedagogik texnologiya: tahlil, ta'rif, mulohazalar: Maqolalar to 'plami.-T., 2010 


\title{
TIBBIY REKLAMA MATNLARIDA MOTIVLAR
}

\author{
Sobirova Dilnoza Rasulovna \\ Buxoro davlat universiteti \\ tayanch doktoranti $(\mathrm{PhD})$ \\ sobirova.2018@inbox.ru
}

Annotatsiya. Ushbu tezisda reklamalarda iste'molchilarni ma'lum bir preparatni xarid qilishga undovchi motivlar xususida so 'z boradi. Keltirilgan fikrlar ommaviy axborot vositalari orqali e'lon qilinayotgan tibbiy reklamalar misolida dalillanadi.

Kalit so'zlar: tibbiy reklama, motiv, dori-darmon, ratsional motiv, hissiy motiv, salomatlik, ta'sir.

Reklamashunos olimlar - A.Krilov va O.Zuenkova tomonidan "Реклама биоактивных добавок и витаминов" nomli tadqiqotida dori-darmon vositalarini reklama qilishda ratsional va hissiy motivlarning faol qo'llanishi xususida so'z yuritiladi [2]. Quyida biz ushbu motivlar asosida reklama matnlarini tahlilga tortishga harakat qilamiz.

Ratsional motivlar bevosita adresat ongiga ta'sir etuvchi motiv bo'lib, uning quyidagi ko'rinishlari mavjud:

Foydalanish qulayligi motivi. Ushbu motiv qo'llangan dori-darmon reklamasida asosiy urg'u preparatni qabul qilishning qulayligiga qaratiladi. Tabiiyki, bu tibbiy reklama matnlarida $\mathrm{o}^{6} \mathrm{z}$ aksini topadi: "Koteks" bu faqatgina himoya emas, uning yumshoq, to 'rli yuzasi, tez shimuvchi markazi tufayli men o 'zimga yuz foiz ishonch va qulaylikni his etaman. Kotex har kun olg'a intil!

(Koteks tibbiy vositasi reklama matnidan). Korega kun davomida qulaylik (Korega dori vositasi reklama matnidan).

Xavfsizlik motivi. Trombopol infarkt va insult xavfini bartaraf qiladi. Ichakda eruvchan qobig'i tufayli oshqozonning shilliq pardasiga ziyon yetkazmaydi. (Trombopol dori vositasi reklama matnidan).

Individual moddalarning ta'siri motivi. Bunda preparat tarkibidagi moddalarning ijobiy xususiyatlari adresatga yetkaziladi.

Tarkibida lanolin, Hamda besh provitamin, Foydalansangiz shifo bo 'lishi tayin. Minglab-minglab onaning Ishongani bipanten (Bipanten dori vositasi reklama matnidan).

Davolanish vaqtini tejash, ta'sir tezligi motivi. Kreon yuzlab fermentli minimikrosferalardan iborat bo 'lib, ular atigi o' $n$ besh daqiqada ta'sir ko 'rsata boshlaydi va hazm qilishni yaxshilaydi (Kreon dori vositasi reklama matnidan).

Ishonchlilik va kafolat motivi. Antibiotik qabul qilishimning birinchi kunidan ishonaman Lineks forte bilan oshqozon ichagim ishlashi himoyalangan. Lineks Forte antibiotik qabul qilishning birinchi kunidan (Lineks forte dori vositasi reklama matnidan).

2. Hissiy motivlar adresat hissiyotiga ta'sir ko'rsatadi. Uning quyidagi ko'rinishlari mavjud:

Go'zallik, yoshlik, uyg'unlik motivi. Lazolvan eng yaxshi damlar siz bilan (Lazolvan dori vositasi reklama matnidan). Loratal. Ajoyib tabiat bilan uyg 'unlik (Loratal dori vositasi reklama matnidan).

Qo'rquv, muammolardan xalos bo'lish motivi. Bunda stress, xavf, kasallik, muammolardan himoya qilish, dori vositalariga bo'lgan ehtiyojga urg'u beriladi. Yaqinlarim bilan quchoqlab kulishishni yaxshi ko 'raman. Qorin og 'riganda esa quchoqlashish ko'ngilga sig'maydi. Noshpa kerakli joyga ta'sir qiladi. Bolaligimizda onamiz bizni silab-siypalaganidek ehtiyotkorlik bilan og 'riqni spazm yo 'qotishga yordam beradi. Nosh-pa qorin og 'riganida. Sanofi Fransiya (No-shpa dori vositasi reklama matnidan).

Zamonaviylik, yetakchilik motivi. Aktrisa bo 'lish oson emas: suratga tushishlar, sovg'alar, mashhurlik... - Dada mening mashhurlikka allergiyam bormi? - Sening qulupnayga allergiyang bor. Zodak! Allergiyasiz, baxtli onlar...Sanofi Fransiya (Zodak dori vositasi reklama matnidan).

Bolalarga g'amxo'rlik qilish motivi. Mening kichkintoyim qorinchasining yaxshi faoliyati uchun nima yordam beradi. Lineks dlya detey uning bifodobakteriyalari xuddi bolajonlar ichaklaridagi kabi hazm qilish buzilishining oldini olish hamda ichak mikroflorasini tiklashga yordam beradi. Bayram dasturxoni ham qorinchamiz dam bo 'lishi uchun bahona emas. Lineks dlya detey bolajonlarni birinchi kundan qo 'llab-quvvatlash (Lineks dori vositasi reklama matnidan).

Bolaning qorni og'risin, faqat qotib-qotib kulganda. Me'da-ichak faoliyatining buzilishida Enterojermina suspenziyasini qabul qilish uchun tayyor shaklda. Enterojermina ichak mikroflorasini 
tiklashga yordam beradi. En-te-ro-jer-mi-na (Enterojermina dori vositasi reklama matnidan).

Tadqiqotlarda ikki tomonlama ta'sir motivi yetakchilik qilishi xususida so'z boradi [2]. Biroq biz kuzatishlarimiz davomida uch tomonlama ta'sir motivi faol qo'llanishda ekanligiga guvoh bo'ldik. Uch yoqlama kuch: og 'riqni, qizarishni va infeksiyani yo 'qotadi. Ekzoderil uch yo 'nalishda ta'sir ko 'rsatib, achishishni va qizarishni yo 'qotadi. (Ekzoderil dori vositasi reklama matnidan). Valtaren og'riq, yallig'lanish, va shishni davolash uchun uch tomonlama ta'sir ko'rsatadi (Valtaren dori vositasi reklama matnidan).

Essensiale forte Nuch tomonlama ta sirga ega bo 'lib jigar hujayralarini qayta tiklaydi. (Essensiale forte $N$ dori vositasi reklama matnidan).

Xulosa qilib aytganda, reklama matnlarini, xususan, tibbiyotga oid reklama matnlarini tuzishda motivlarga ahamiyat berish g'oyat muhim. Kuzatishlar davomida tibbiy reklamalarda hissiy motivlar faol qo'llanishda ekanligiga guvoh bo'ldik.

\section{Adabiyotlar:}

1. Крылов А., Зуенкова О. Реклама биоактивных добавок и витаминов. 2003.

2. https://knowledge.allbest.ru/marketing/3c0a65635b2ad78a4d53a88521206d37_3.html 


\title{
ТАЪЛИМДА “CASE-STUDY” ТЕХНОЛОГИЯСИДАН ФОЙДАЛАНИШ ВА УНИНГ АХАМИЯТИ
}

\author{
Абдурахимова Шахноза Абдурашитовна \\ ЎзДжТСУнинг Хорижий тилллар кафедраси ўқитувчиси \\ Рахимкулиева Гуласал Матчановна \\ УзДЖТСУнинг 3-курс талабаси
}

\begin{abstract}
Аннотация: Мазкур мақолада “case-study" ууқитиш технологияси услубларининг кўп вариантлилиги ва уни спортпедагогикаси йўналишдаги фанларга хам қўллаш мумкинлиги, шунингдек, мазкур масаланинг хозирги кундаги муаммолари ва уни бартараф этиш чоралари тўғрисида мулохаза юритилади. “Case-study" технологиясининг педагогик ахамияти ёритиб берилади.
\end{abstract}

В данной статье речь идёт о многовариантности технологии обучение "case-study" и возможности использования данной технологии в предметах по спортивному педагогическому направлению, сегодняшнее состояние и проблемы данного вопроса а также, пути их предотвращения. Раскрытыпедагогическоезначениетехнологии "case-study".

This article discusses the many variants of the case study methodology and its application to sport pedagogy subjects, as well as the current issues of the issue and the measures to overcome it. The pedagogical significance of Case-Study technology is highlighted.

Таянч сўзлар: “case-study” ўқитиштехнологияси, кейс-услубдаўқитиш, анъанавийўқитиш, аудитория-дарстизими, интерфаолусуллар, педагогиктехнология, халокатлармуаммоси, авторитартизим, мантиқий-аналитикфаолият.

Ключевые слова: технология обучение “case-study”, обучение по методу кейс, традиционое обучение, система урок-аудитория, интерактивные методы, педагогическая технология, логическо-аналитическая деятельность

Key words: Case study teaching technology, Case-mode teaching, traditional teaching, auditorium, interactive methods, pedagogical technology, logical and analytical activities.

Мамлакатимиз миқёсида олиб борилаётган кенг қамровли ислохотлар ўлароқ Олий таълим тизимининг модернизациялаш йўлига ўтаётганлиги муносабати билан Ўзбекистонда ўқитишнинг янги самарадор услубларини излаш амалга оширилмоқда. Жумладан, Ўзбекистон Республикаси Президентининг 2012 йил 28 майдаги “Малакали педагогик кадрлар тайёрлаш хамда ўрта махсус, касб-хунар таълими муассасаларини шундай кадрлар билан таъминлаш тизимини янада такомиллаштиришга оид чора-тадбирлар тўғрисида"ги Қарорида Олий ва ўрта махсус таълим, ўрта махсус, касб-хунар таълими муассасалари таълим жараёнида илғор педагогик услуб ва технологиялардан бири “casestudy" ўқитиш технологиясининг жорий этилиши хусусида хам тўхталган [1].

"Case-study" услубининг ривожланиш тарихи, илк бор ишлаб чиқилган жой Гарвард университети (АҚШ) хисобланади. Дастлабки кейсдан 1870 йили Гарвард университетининг хукуқ мактаби ўқув жараёнида фойдаланган. Ушбу услуб 1920 йилдан Гарвард бизнес мактаби (Harvard Business School) жорий қилинган.

Хозирги кунда Гарвард бизнес мактаби кейслардан таълим сохасида фойдаланиш бўйича етакчи хисобланади ва уларнинг мухокама қилишга ўқув вақтиниг 90 фоизи ажратилган. $\mathrm{XX}$ асрнинг 50 йилларидан бизнес- кейслар Ғарбий Европага кириб келди ва кенг тарқалди. Бугунги кунда узоқ ғарбий давлатларда кейслар ўқув режасининг 25 фоизини ташкил қилади.

“Case-study" услуби 2000 йил бошидан эътиборан табиий-илмий ва техника фанларини ўқитишда хорижий давлатлар амалиётида кенг фойдаланиб келимокда. Масалан, Journal of Chemical Education журнали мос услубий материалларни доимий равишда чоп этиб келмоқда. “Case-study” услуби собиқ иттифоқда кўп вақтлар қўлланилмади. Унга қизиқиш фақат XX асрнинг 20 - йиллари охирида пайдо бўлди. Ушбу услуб Россия таълим муассасаларида XX асрнинг 90 - йилларидан бошлаб қўлланиб келинмоқда. Хозирги вақтда “case-study" ишлаб чиқишнинг иккита классик мактаблари мавжуд бўлиб, булар Гарвард (Америка) ва Манчестер (Европада) хисобланади. Бу мактабларнинг кейсни ўқитиш бўйича ўз йўллари мавжуд бўлиб, ўхшаш ва фарқли томонлари хам бор. Масалан, муаммоли вазиятнинг ечимини топишни ўрганиш йўли бўйича: Гарвардда - ягона тўғри ечимни излашга ўргатиш бўлса, Манчестерда 
- муаммони хал этишнинг кўп ечимли вариантини кўзда тутади. Хажм жихатдан: Америка кейслари ўнлаб сахифали матнни ва кўплаб иллюстрацияларни ўз ичига олса, Европа кейслари эса-хажми бирмунча камроқ бўлган.

“Case-study” ўқитиш технологиялари бугунги кунда нима учун долзарб бўлиб бораётганлиги, нима учун мазкур технологиялар таълимнинг хозирги куни, келажаги бўлиб қолганлиги хамда уларнинг мохияти нимадан иборат эканлиги каби саволлар кетма-кетлиги бўлиши табиийдир. "Case-study" ўқитиш усулининг долзарблиги шундаки: - биринчидан, аниқ вазият таълим беришни хақиқийликка боғлайди, яьни кейс таълим олувчиларга вазиятни ташхис қилиш, фаразларни ифодалаш, муаммоларни аниқлаш, кўшимча ахборотларни йиғиш, фаразларга аниқлик киритиш ва муаммоларни ечиш бўйича аниқ босқичларни лойихалашда амалий фаолиятларини моделлаштириш имконини беради; - иккинчидан, кейс таълим олувчиларга тахлил қилиш, тенглаштириш йўлларини қидириш ва муаммони ечиш эркинлигини беради; учинчидан, кейсни кўриб чиқишда таълим олувчилар таълим олиш жараёнини яратадилар ва жараёнда ўзаро харакатда хақиқий фикр алмашиш холатларини яратадилар. Энг асосийси, тажриба ва тахлилий натижаларга кўра, тингловчи хотирасига 10 фоизкўриш орқали (кўрганда) - 20 фоиз кўриб, эшитиш орқали (кўрганда ва эшитганда) - 50 фоизи кўриб, эшитиш орқали қабул қилиш ва мунозарада (кўрганда, эшитганда ва бажарганда) -70 фоиз кўриб ва эшитиш орқали қабул қилиш ва мунозарада, амалий имконятларни қўлланилганда (кўрганда, эшитганда, бажарганда ва сўзлаб берганида) - 90 фоиз ахборот қолиши аниқланган бўлиб, мазкур ўқитиш усули юқоридаги жараёнларни ўзида тўлиқ қамрагандир. Вазиятни тахлил қилиш услуби - кейс услуби номи билан маълум бўлган ўқитиш услуби хақидаги сўз бўлиб, Кейс-стади (инглизча caseтўплам, аниқ вазият, stady-таълим). Унинг мохияти шундан иборатки, талабаларга реал хаётий вазиятни мулохаза қилиш таклиф этилади, унинг тавсифи бир вақтнинг ўзида нафақат қандайдир амалий муаммони акс эттириб қолмай, балки ушбу муаммони ечимини топишда ўзлаштириладиган маълум билимлар тизимини долзарблигини таъминлайди. Шу билан бирга муаммонинг ўзи бир хил ечимга эга бўлмайди.

"Case-study" таълим, ахборотлар, коммуникация ва бошқарувнинг қўйилган таълим мақсадини амалга ошириш ва кейсда баён қилинган амалий муаммоли вазиятни хал қилиш жараёнида прогноз қилинадиган ўқув натижаларига кафолатли етишишни воситали тарзда таъминлайдиган бир тартибга келтирилган оптимал усуллари ва воситалари мажмуидан иборат бўлган таълим технологиясидир. Бошқача қилиб айтганда, у амалий холатларни ўқитиш усули хисобланади. Мазкур услуб ўқитишнинг специфик яъни (ўзига хос) услуби сифатида унинг ўзигагина хос бўлган таълим масалаларини хал қилиш учун қўлланилади. Ўқитишни технологиялаштириш ва оптималлаштириш, ўқитишда турлича типлар ва формаларни қўллаш ва уларни услубий жихатдан бойитиш кейс-услубнинг асосий муаммолари бўлиб хисобланади. "Case-study" услуби ўқитишнинг интерфаол услуби бўлганлиги сабабли у талабаларда ижобий таассурот уйғотади, талабалар унда назарий билимларни ўзлаштириш ва материалдан амалда фойдаланишни таъминлайдиган уй̆инни кўрадилар.

Вазиятларни тахлил қилиш талабаларнинг профессиналлашувига, уларнинг улғайишига етарлича кучли тарзда кўмаклашиши, уларда ўқишга нисбатан қизиқиш ва ижобий мотивацияларни (ундовчи сабабларни) шакллантириши хам мухим ахамият касб этади. Кейсуслуб ўқитувчининг фикрюритишинингтимсоли сифатида, унгаянгича ўйлаш ва харакатқилиш, ўзининг ижодий салохиятини янгилаш имконини берадиган ўзига хос модельсифатида чиқади. Бу ўринда ўқув жараёнини кенг демократлаштириш ва модернизациялаш, ўқитувчиларни қарамликдан халос қилиш, уларнинг педагогик фаолиятида фикр юритиш, этика ва ундовчи сабабларнинг ривожланиш усулларини шакллантириш асосий муаммолар бўлиб хисобланади. Кейс ўзида қандайдир-бир ролли тизимни тақдим қилади. Роль деганда маълум бир ижтимоий позицияларни эгаллаган шахсларга нисбатан куйиладиган талабларнинг жамланмаси тушунилади. Кейсда ролларнинг юқори даражада концентрациялашуви (жамланиши) кейсуслубнинг ўта ролли формага - ўқитишнинг ўзида интеллектуал ривожланишнинг нозик технологиясини ва кенг қамровли назорат қилишни бирлаштирадиган уйин услубига айланишига олиб келади. Кейсда харакатлар ёки тасвирланишлар билан берилади - бунда уларни (оқибатлар, самарадорликни) ўйлаб кўриш талаб қилинади, ёки улар муааммони хал қилиш усуллари сифатида таклиф қилиниши лозим бўлади. Бироқ хар қандай холатда хам амалий харакатлар моделини ишлаб чиқиш ўқувчиларнинг профессионал фазилатларини шакллантиришнинг самарали воситаси бўлмоғи лозим. 
Кейс-услубда ўқитиш билан анъанавий ўқитиш услублари органик яхлитликда фойдаланиш лозим бўлади, чунки анъанавий ўқитиш услублари талабаларда мажбурий меъёрий билимларни хосил қилса, “case-study” яъни вазиятли ўқитиш эса мулохаза юритишнинг кўп вариантли, тизимлилигини ривожлантириш билан динамик вазиятлар шароитларида ечимни қидириш ва билимлардан фойдаланишни ўргатади. Улардан фойдаланмаслик шунга олиб келиши мумкинки, бунда бўлғуси мутахассис зарурий меъёрий “скелет” га эга бўлмасдан қолади. Унинг барча билимлари хеч қандай услубий принциплар ёки тизимларга эга бўлмаган вазиятлар кўплигини билишга қаратилади халос.

Мутахассис тўплаган билимларини, ўзи аввал тўқнаш келган вазиятларни мулохаза қилиш учунгина фойдаланиш мумкин бўлади, янги вазиятларга эса у “қуруқ қўл билан ва рулсиз" кириб келади. Бошқача қилиб айтганда, аниқ мақсадсиз дуч келган томонга, таваккқлига харакат қилади. Хозиргача жахонда энг кўп таркалган ўқитишнинг аудитория-дарс тизимида машғулотлари асосий бирлиги дарс бўлиб, у битта фанининг битта мавзусига бағишланади ва ўқитувчи томонидан бошқарилади. Талаба фаолиятида пассивликни келтириб чиқараётган сабабларни тахлил этадиган бўлсак, талабаларнинг ўз устида мустақил изланишларга қизиқишнинг сўниши, талаба рухиятини бир хилликдан ўзини табиий химоя қилиши туфайли пайдо бўлаётгандир.

Талабаларни фанга бўлган муносабатини фаолллаштиришда олий таълимнинг замонавий педагоглари бирон бир ечим ўйлаб топмасалар, талабалар пассивлигича қолаверадилар. Талабаларни фаолллаштириш, яъни машғулотларга нисбатан “қўзғатиш” учун замонавий педагогиканинг турли интерфаол усулларини сайқаллаш ва навбатма-навбат ўз ўрнида қўллаб бориш даркордир. Интерфаол усулларни адабиётларда берилганидек, яъни айнан қўллаши шарт эмас. Балки усулларни янгиликлар билан бойитиши, сайқаллаш, яъни такомиллаштириб бориш лозим бўлади. Тегишли адабиётлар тахлили шуни кўрсатмоқдаки, педагогик технологиянинг туб мохияти ўқитишнинг анъанавий, ўқитувчи томонидан баён қилиш, талабаларга тайёр билимларни бериш усулидан воз кечиб талабаларни кўпроқ мустақил таълим олишга ундашдан иборат. Бунда ўқитувчи талабалар билиш фаолиятининг бошқарувчиси, маслахатчи, якуний натижага йўлловчи шахс вазифасини бажарадилар. Одатда, инсонда фикрлаш зарурати, унинг олдида янги муаммо, янги холат, янги мақсад пайдо бўлганда вужудга келади. Масалан, шундай холат хайдовчида автомобилининг двигатели номаълум сабабларга кўра ишламай қолиб, йўлда тўхтаб қолган вазиятда бўлади. Хайдовчининг двигателни ўт олдириш ва унинг манбалари хақидаги билимлари етарли бўлмаганлиги туфайли, у двигателни ўт олдиришга қийналади. Бундай пайтда одамнинг фикри ёрдамга келиши керак бўлган (хотира шундай қилади) ностандарт вазият вужудга келади. Одатда, бу холатда, янги мақсад пайдо бўлиб, унга эришишга маълум восита ва усуллар зарур бўлса-да, улар етарли бўлмайди. Бундай вазиятлар муаммоли деб аталади. У аниқ бўлмаган ва кам англанган тасаввурлар вазиятни яхшилаб ўйлаб кўриш зарурати хақида сигнал бераётган вақтда, фаолиятда пайдо бўладиган қийинчилик (тўсиқ)ларда рўй беради. Уни англаш жараёнида бир вазиятдан, ечиш учун анча яқин, лекин ечилмаган бошқа вазиятга ўтиш содир бўлади. Уни хал қилиш учун, маълумни номаълумдан ажратган холда, муаммоли вазиятни тахлил қилиб чиқиш лозим.

Натижада муаммо, ечимни излаш масаласи қўйилган масаланинг мавқеини, олинган маълумотлар (маълум ва номаълумлар) эса, фикр мақсадга йўналтирилган, унгача маълум бўлмаган янада янги шартлар ва талаблар аниқланадиган масала мавқеини оладилар [3]. Бу янги далиллар масалани ечишга ёрдам берадиган кўрсатмалардан иборат бўлиб қолиши мумкин. Вазият (масала)нинг саволларини ифодалашга боғлиқ равишда унинг ечимини излаш йўналиши хам аниқланади.

1. Гладких И.В. Методические рекомендации по разработке учебных кейсов / Гладких И.В. // Вестник Санкт - Петербургского университета .- 2005. - Вып .

2. - С. 165-173. 84 ТОШКЕНТ ДАВЛАТ ПЕДАГОГИКА УНИВЕРСИТЕТИ ИЛМИЙ АХБОРОТЛАРИ ПЕДАГОГИКА 3/2017 (12) 2. Темирова М.А. Таълимтехнологиясида “Сasestudy” услубларинингқўлланиши.//Ноанъанавийкимёвийтехнологияларваэкологикмуаммолар: Респ. илмий- амалийанжумани. - ФарПИ, 2015.

3. Темирова М.А. Замонавий мухандислар тайёрлашда “case-study” услубида ўқитишнинг ахамияти. //Таълимда фалсафанинг долзарб масалалари: респ. илмий-амалий конф. - ТАЙИ, 2016. 


\section{УДК: 81`32}

\section{РОЛЬ ЛИНГВИСТИЧЕСКИХ КОРПУСОВ В НАУЧНЫХ ИССЛЕДОВАНИЯХ}

Бурнашев Ринат Фаритович, ст. преподаватель кафедры гуманитарных наук и информационных технологий Нематуллаева Нилуфар Баходировна, студентка факультета теории и практики перевода Худоярова Парвина Нодиржоновна, студентка факультета романо-германских языков Самаркандский государственный институт иностранных языков г. Самарканд, Узбекистан rinat.burnashev@inbox.ru

Аннотация: в статье рассмотрены технологии проведения научных исследований на базе лингвистических корпусов для устанавливания границы, иерархии и хронологии смыслов слов и выражений.

Ключевые слова: лингвистический корпус, значение, частотность, толковый словарь, двуязычный словарь, статистический словарь.

Лингвистические корпуса имеют очень широкий спектр использования в самых различных областях человеческой жизни: от высокой теории до обыденной рекламы. На переднем плане с точки зрения востребованности корпусов в современном мире находятся научные исследования на их базе. Но, во-первых, о них, так или иначе, говорится постоянно и предметно, а во-вторых, научные исследования тоже редко являются самоценной и замкнутой на саму себя задачей. По этой причине определим сферы более конкретно, подчеркнув, что последовательность их расположения не характеризует степень важности данного направления и удельного веса его использования по сравнению с другими. Последовательность произвольна.

Для любой области языкознания полезны корпусные исследования. Любую область они способны поднять на новый уровень осмысления материала. Актуальны они и для других наук, в первую очередь, истории, литературоведения, социальной антропологии, социологии, политологии, психологии и философии. Без корпусов теперь сложно себе представить составление достоверных толковых словарей. Именно корпуса позволяют фиксировать появление новых слов, динамику семантики уже существующих, выход слов из активного употребления [1].

Например, с помощью The Collins Corpus можно установить, что до 2005 г. слово «сloud» - «облако» использовалось, главным образом, в его метеорологическом значении. В 1990-х гг. 100 \% всех примеров «облако» в письменном подкорпусе относятся либо к метеорологии, либо к облакам пыли, дыма и т. п. В последние же годы с сохранением прежнего значения стало частым «cloud» - «облако» в смысле веб-хранилища для файлов: «хранить в/на облаке». Так, в 2005-2009 гг. более 60 \% найденных в корпусе записей относятся к вычислительной технике. Наряду с новым значением возникло новое словосочетание «cloud computing» - «облачные вычисления» (т. е. вычисления, которые производятся через Интернет на арендованных мощностях и программном обеспечении) [2]. Этого выражения не существовало в корпусе 1990-х гг., но есть более 500 фиксаций в корпусе 2005-2009 гг. Появилась новая фраза «in the cloud» - «в облаке».

The Collins Corpus в несколько раз больше Национального корпуса русского языка, в котором статистический анализ по временным отрезкам затруднён, в конечном счёте, его приходится осуществлять вручную. Но в целом перебор примеров из Национального корпуса русского языка позволяет констатировать, что аналогичная картина со словом «облако» наблюдается в русском языке, но с существенными особенностями. Словосочетание «облачные вычисления» фиксируется в русском языке несколько позже, с 2011 г., и представлено 17 вхождениями по разным грамматическим формам. 17 в 29,4 раза меньше, чем 500. При этом Национальный корпус русского языка в 7,5 раза меньше, чем The Collins Corpus. Из простой пропорции видно, что частотность употребления словосочетания в английском языке значительно выше, чем в русском.

В русском языке словосочетание «cloud computing» кроме перевода «облачные вычисления» 
имеет ещё перевод «“облачная” платформа», «“облачная” программная платформа» и даже «проводить проектные работы “в облаке”, т.е. в режиме удалённого доступа» (4 вхождения, 2011 г.). На статистику они не влияют, но указывают на то, что выражение с достаточной степенью точности не адаптировано. В Национальном корпусе русского языка из 84 вхождений «в облако» только одно относится к компьютерной сфере. Из 306 вхождений «в облаке» только одно относится к компьютерной сфере. Эти единицы очень показательны в сопоставлении с 60 \% компьютерных значений в The Collins Corpus. Согласно Национального корпуса русского языка 99,99 \% словоупотреблений «в облаке» остаётся за традиционной сферой.

Любой филолог понимает, что подобного типа информация бесценная для толковых, двуязычных и статистических словарей. Она устанавливает границы, иерархию и хронологию смыслов. Она позволяет носителям языка адекватно воспринимать свой и иностранный язык. Эта же информация позволяет делать массу выводов общекультурного плана от mривиальных до спорных. К числу тривиальных относится то, что компьютерные программы в англоязычных странах существенно опережают, так как компьютерная тематика имеет приоритетное значение для социума. К числу спорных можно отнести два предположения. Сейчас русский язык гораздо консервативнее английского. Национальный корпус русского языка недостаточно последовательно отражает современную речевую практику. Очень показательны в этом отношении 60 \% от общего числа «в облаке» в значении «внешнее по отношению к компьютеру сетевое хранилище информации» в The Collins Corpus против 0,01 \% в Национальном корпусе русского языка (подсчёты 27.02.2021). Многоязычные корпуса позволяют проводить такие сопоставления автоматически.

\section{Список литературы}

1. Бурнашев Р.Ф., Фаррухова Ф.Ш. Лингвистический корпус как база для организации информационного поиска. // Научный журнал «SCIENCE AND EDUCATION» Volume 2, Issue 3, Март 2021. ISSN 2181-0842. C. 195-199.

2. Бурнашев Р.Ф., Фаррухова Ф.Ш. Особенности использования облачных технологий в современных условиях. // Научный журнал «SCIENCE AND EDUCATION» Volume 2, Issue 3, Март 2021. ISSN 2181-0842. C. 200-205. 


\section{ИНОСТРАННЫЕ ЯЗЫКИ И ИСПОЛЬЗОВАНИЕ ИНФОРМАЦИОННЫХ ТЕХНОЛОГИЙ В ИХ ОБУЧЕНИИ}

Жумаева $\Gamma$

Студентка термезского филиала Ташкентского педагогического института им Низами

Annotation: This article examines the usage of information technologies, methods and techniques of it, informatization and computerization of education system. applying internet and new informational application to educational system is also described here.

В сегодняшнем мире информационные коммуникационные технологии интенсивно проникают в процесс обучения иностранным языкам во всех сферах обучения.

Учебные пособия по обучению и методике преподования иностранному языку с использованием коммуникационных и информационных компьютерных технологий, разрабатываются методики применения компьютера в преподавании иностранных языков в ВУЗах, также исследуется использование Интернета в обучении иностранному языку .

Изучается формирование иноязычной компетенции в социокультурном пространстве диалога на основе использования информационных и коммуникационных технологий, также создается методическая система формирования поликультурной языковой личности посредством Интернет-коммуникации в процессе обучения иностранным языкам. И нужно отметит, что в условиях стремительного развития информационных и коммуникационных технологий и их широкого применения в сфере экономики и бизнеса, умение пользоваться компьютерными технологиями в профессиональном контексте становится реальной необходимостью.

Одним из приоритетных направлений процесса информатизации современного общества является информатизация образования - внедрение средств новых информационных технологий в систему образования.

Это сделает возможным:

- совершенствование механизмов управления системой образования на основе использования автоматизированных банков данных научно-педагогической информации, информационнометодических материалов, а также коммуникационных сетей;

- совершенствование методологии и стратегии отбора содержания, методов и организационных форм обучения, соответствующих задачам развития личности обучаемого в современных условиях информатизации общества;

- создание методических систем обучения, ориентированных на развитие интеллектуального потенциала обучаемого, на формирование умений самостоятельно приобретать знания, осуществлять информационно-учебную, экспериментально -исследовательскую деятельность, разнообразные виды самостоятельной деятельности по обработке информации;

- создание и использование компьютерных тестирующих, диагностирующих, контролирующих и оценивающих систем.

В настоящее время значительные преобразования в области образования затронули и обучение иностранному языку в вузе. В частности стали интенсивно внедрятся в учебный процесс новые информационные технологии, такие как использование Интернет-ресурсов, обучающих компьютерных программ и, т.п.

Компьютеры стремительно вошли в нашу жизнь и в процесс обучения английскому языку, несколько потеснив традиционные методики и заставив преподавателей иностранных языков решать проблемы, о существовании которых несколько десятков лет назад ни один лингвист даже не подозревал. Нет ничего удивительного в том, что не все преподаватели оказались готовыми к широкому внедрению компьютеров в такую нетрадиционную сферу, как обучение иностранным языкам.Система образования не может быть независимой от общественного и политического устройства государства, она во все времена откликалась на социальный заказ. Именно в силу этого политика государства в последнее время направлена на то, чтобы внедрить информационные технологии в школы и вузы, превратить стихийный процесс, каким он по преимуществу был в течение целого ряда лет, в управляемый и контролируемый, привлечь к работе над новыми учебными материалами специалистов в предметных областях, стимулировать компьютерные фирмы к созданию электронной обучающей продукции для 
российских школьников и студентов.Необходимо, чтобы каждый преподаватель понял простую мысль: компьютер в учебном процессе - не механический педагог, не заместитель или аналог преподавателя, а средство при обучении детей, усиливающее и расширяющее возможности его обучающей деятельности. То, что преподаватель желает получить в результате использования машины, в неѐ необходимо запрограммировать.

Таким образом, компьютер берѐт на себя львиную долю рутинной работы преподавателя, высвобождая ему время для творческой деятельности, которая на современном уровне развития техники не может быть отдана компьютеру.

Как известно, пригодность технических средств обучения и контроля для использования на занятиях по иностранному языку определяется по следующим критериям: во-первых, они должны способствовать повышению производительности труда и эффективности учебного процесса, во-вторых, обеспечивать немедленное и постоянное подкрепление правильности учебных действий каждого учащегося; в-третьих, повышать сознательность и интерес к изучению языка, в-четвѐртых, обеспечивать оперативную обратную связь и пооперационный контроль действий всех обучаемых, в-пятых, обладать возможностью быстрого ввода ответов без длительного их кодирования и шифрования. Как показывает практика, из всех существующих средств обучения компьютеры наилучшим образом «вписываются» в структуру учебного процесса, наиболее полно удовлетворяют дидактическим требованиям и максимально приближают процесс обучения английскому языку к реальным условиям. Компьютеры могут воспринимать новую информацию, определѐнным образом обрабатывать еѐ и принимать решения, могут запоминать необходимые данные, воспроизводить движущиеся изображения, контролировать работу таких технических средств обучения, как синтезаторы речи, видеомагнитофоны, магнитофоны. Компьютеры существенно расширяют возможности преподавателей по индивидуализации обучения и активизации познавательной деятельности учащихся в обучении английскому языку, позволяют максимально адаптировать процесс обучения к индивидуальным особенностям учащихся.

Каждый учащийся получает возможность работать в своѐм ритме, т.е. выбирая для себя оптимальные объѐм и скорость усвоения материала. Применение компьютеров на занятиях английского языка значительно повышает интенсивность учебного процесса. При компьютерном обучении усваивается гораздо большее количество материала, чем это делалось за одно и то же время в условиях традиционного обучения. Кроме того, материал при использовании компьютера усваивается прочнее.

\section{Литература:}

1. Карпов К.В. Применение информационно-коммуникационных технологий в обучении иностранным языкам . М. «Высш. школа», 2013

2. Городилова Г.Г. Аудиовизуальные и технические средства в обучении. Изд. МГУ,2012 


\title{
ҚАДИМГИ ТУРКИЙ ТИЛДАГИ АRÏ ЛЕКСЕМАСИНИНГ ХОЗИРГИ ТУРКИЙ ТИЛЛАРГА МУНОСАБАТИ
}

\author{
Киличов Назарбай Раджапбаевич, \\ филология фанлари бўйича фалсафа доктори $(\mathrm{PhD})$, \\ Қорақалпоқ давлат университети
}

Каримова Дилфуза,

Қорақалпоқ давлат университети талабаси тел.: +97-787-92-97; e-mail: nkilichovr@mail.ru

Қадимги ёзма манбалар тилига хос луғавий бирликлар кейинги даврларда, туркий диалектларнинг алохида тиллар бўлиб шаклланиб, дифференциация бўлган даврларда хам қатор туркий тилларда сақланиб қолган, туб, асл луғавий қатламидан ўрин олган хамда хозирги кунгача кўлланилиб келинмоқда.

Маълумки, сўзнинг лексик маъноси қотиб қолган, ўзгармас ходиса эмас, у анча барқарор бўлса-да, маълум омиллар таъсирида узоқ йиллар давомида ўзгариши мумкин ${ }^{1}$. Мазкур ўзгаришлар маълум бир тилдаги ташқи ва ички таъсирлар, яъни ижтимоий-иқтисодий-сиёсий тузум ўзгариши, инсоният ақл-тафаккури, мехнат фаолияти, маданият, санъат, спорт, техника сохалари тараққиёти, шунингдек, тилларнинг бир-бирига таъсири натижасида юз беради. Масалан, мустақиллик йилларида фан-техника ютуқлари натижасида мавжуд маъноларини сақлаган холда бандлик, юкламоқ, ўқимоқ сўзларининг янги маънолар касб этганлиги, қўшимча семалар кўшилганини кузатишимиз мумкин ${ }^{2}$. Демак, лексик маъно тараққиёти деганда маъно кўчиши, кенгайиши ва торайиши, бундаги миқдор ва хажм ўзгаришлари шулар жумласидандир ${ }^{3}$.

Дархақиқат, қадимги туркий тилдаги arï= лексемасининг маъно тараққиёти, мазкур лексеманинг қадимги туркий тилдаги маънолари ва хозирги туркий (ўзбек, қорақалпоқ, туркман) тиллари, хусусан, ўзбек диалектларига муносабатини тадқиқ қилиш тилшунослик учун мухимдир.

arï / arïmaq «тозаламоқ, айирмоқ, йўқ қилмоқ» сўзи қадимги туркий тилда 'тозаланмоқ, тоза бўлмоқ', ‘софланмоқ', ‘покланмоқ', ‘кетказмоқ' маъноларида қадимги туркий ёзма манбалардан дастлаб “Олтун ёруғ” асарида кўлланилган. Замонавий туркий тилларда мазкур феъл фаол кўлланилиб, маъно торайиши ва маъно кенгайиши ходисасига учраган. Жумладан, хозирги ўзбек адабий тилида аримоқ феъли 'борлиги кетмоқ, йўқолмоқ (бор холда давом этаётган нарсалар хақида)' маъноларини ифодалайди: касали аримоқ, дарди аримоқ. Кексалар бор хонадонлардан хайру баракот аримайди ${ }^{4}$. Бу маъно феълнинг харакат номи шакли орқали хам юзага чиққанлигини кузатишимиз мумкин: Ахмаднинг фалокати ариши эхттимоли борлиги хуақ̧ида қ̧исқагина сўзлади. [ЎТИЛ, I, 98]5. Бундан кўришимиз мумкинки, ушбу феъл касал, дард, фалокат каби инсон жисми ва рухиятига ёт салбий мавхум тушунчалар хамда кир, чанг кабиларнинг йуқ бўлиши маъносида аниқ маънога эга бўлган сўзлар билан валентлик хосил қила олади.

Қорақалпоқ тилида арыльй феьли 'айрилмоқ, йўқ бўлмоқ, янгиланмоқ, яхшиланмоқ, қутулмоқ, озод бўлмоқ, жудо бўлмоқ' маъноларини ифодалайди. Масалан: Acay̆ толқынлы Әмиудәрья, Қысққы муздан арылды, Қызкеткенниң тарнаўында, Сарқырады сарылды (Т.Сейтжанов) ${ }^{6}$. Ушбу феъл асосдан хосил бўлган арылтылу, арылмай, арылмас каби шакллар қадимги туркий тилдаги маъноларини сақлаб қолган: Қулласы усы бала туўzалы аўырыўдан арылмайды [ҚТТС, I, 104].

\footnotetext{
1 Jamolxonov H. Hozirgi o'zbek adabiy tili. -T.: "Talqin”, 2005. 156-b.

2 Одилов Ё. Мустақиллик даври лексикасида маъно тараққиёти // Ўзбек тили ва адабиёти, 2016 йил 2-сон, 42-б.

3 Jamolxonov H. Hozirgi o'zbek adabiy tili. -T.: "Talqin”, 2005. 156-b.

4 Ўзбек тилининг изохли луғати. 5 жилдлик, I жилд. - Т.: «Ўзбекистон миллий энциклопедияси» Давлат илмий нашриёти, 2008, Б.97. Ушбу манбадан кўчирма олинган кейинги ўринларда ЎТИЛ шаклида қисқартирилиб, жилди ва сахифаси кўрсатилади.

5 I том 98-бет

${ }^{6}$ Қарақалпақ тилиниң түсиндирме сөзлиги. 4 томлық, I том. -Нукус: «Каракалпакстан», 1982. Б.53. Ушбу манбадан кўчирма олинган кейинги ўринларда ҚТТС шаклида қисқартирилиб, жилди ва сахифаси кўрсатилади.
} 
Шунингдек, ўзбек тилида артмоқ феъли мавжуд бўлиб, қадимги туркий тилдаги arid/ arït феъли асосидаги $i$, $\ddot{i}$ фонемаларининг тушириб қолдирилиши натижасида хосил бўлган. Артмоқ феъли хозирги ўзбек адабий тилида қуйидаги маъноларни ифодалайди: 1) 'бадандаги ёки унинг бирор қисмидаги нам, хўлни сочиқ, латта билан ишқаб кетказмоқ. Шошилмай, ваннахонага кириб, юз-кўлини чайиб, артиниб, шундан кейингина ичкарига ўтди; 2) 'нарса юзасига ўрнашган (илашган, юққан) кир, чанг, сув ва б.ни ишқаб кетказмоқ’: Хонани супуриб, хўл латтада артиб тозалади....сап-сариқ олмалардан йирикровини танлаб, белбов учига артган бўлди-да, очкўзлик билан карсиллатиб тищлади; 3) шв. 'пўстини, пўчоғини олмоқ'; 'арч(и)моқ': сабзи артмоқ; картошка артмоқ [ЎТИЛ, I, 101]. Шуни таъкидлаш жоизки, ушбу сўзнинг тарихий тараққиёти натижасида ўзбек тилидаги 'артмоқ' сўзи морфологик структурасида ўзгариш юзага келган. Бу сўз аслида ари ўзагидан хосил бўлган (ари феълининг маъноси: йўқолмоқ, йўқ бўлмоқ - кетмоқ). Қиёсланг: кўйлакнинг кири ариди, дарди-касали ариди, калла солган жойдан ит аримас (Мақол).Кўринадики, сўз составидаги бу ўзгаришда фонетик ходисанинг роли бор (и тушган) ${ }^{1}$.

Хозирги туркман тилида artmak умумтуркий омонимлик хосил қилади ва куйидаги маъноларда кўлланилади: I. Ортиб қолмоқ, ортиқ бўлмоқ, микдор жихатдан кўпаймоқ, кўп бўлмоқ ва б. II. Тозаламоқ, кеткизмоқ, арчимоқ. Биз учун ушбу омонимик вариантнинг иккинчи маъноси мухим. Унинг маъноларини мисоллар ёрдамида тахлил қиламиз. Жумладан, туркман тилида мазкур сўз қуйидаги маъноларга эга: 1) ‘тозаламоқ, покламоқ, артмоқ’: Artmaz, ýuwmaz tabagynyn̆ daşyny (Magtymguly)'; 2) 'мева-сабзавотларнинг пўстини, пўчоғини олмоқ ёки ейилмайдиган қисмини олиб ташламоқ’ (Daşynyň gabygyny aýyrmak, gerekmez ýerini aýryp arassalamak): Sogan artmak. Käşir artmak; 3) ‘бел ёки курак билан ердаги қорни қириб айирмоқ’: Gar artmak [ТДДС, I, 77].

Умуман, қадимги туркий тилга хос луғавий бирликларни хозирги туркий тиллар ва уларнинг диалектларига муносабатини ўрганиш замонавий туркийшунослик учун мухимдир.

1 Ўзбек тили грамматикаси. Морфология. І том. -Т.: «Шарқ» 1975. Б.109.

2 Türkmen diliniň düşündirişli sözlügi. Iki tomluk. I tom. - Aşgabat: Ylym, 2016 ý. -77-nji s. Ушбу манбадан кўчирма олинган кейинги ўринларда ТДДС шаклида қисқартирилиб, жилди ва сахифаси кўрсатилади. 


\title{
САИД АХМАД ХИКОЯЛАРИДА МИЛЛИЙ МАДАНИЯТ ТАЛКИНИ (“Остона" миллий маданият сифатида)
}

\author{
Махмудова Садоқат Холматовна
}

БухДУ докторанти

\begin{abstract}
Аннотация Ушбу мақолада тадқиқ этилаётган “Остона” концептининг лингвомаданий тахлили миллий “остона”нинг қадрият сифатида кўринишларидан бири Ватан остонаси тушунчаси эканлигидадир. Миллий қадриятлар муттасил ривожланиб, такомиллашиб боради. Ишда миллий маданиятимиз унинг кўп қиррали қадриятларидан бири бўлган Ватан туйғуси, остонаси ва унга сингдирилган мехр-мухаббат тушунчаларини ёш авлодга етказишдир. Тадқиқот натижалари мақолада ўз аксини топган.
\end{abstract}

Таянч сўз ва иборалар: Ватан, остона, қадрият, лингвомаданият,концепт, якдиллик, тарих синовларига, мумтоз қадриятлар.

Маълумки, миллий маданият бутун бир халқнинг ўзига хос тарихини, асрлар давомидаги турмуш тарзи, илмий, маънавий ва моддий салохиятини белгилаб берувчи ходисадир. Миллатнинг жахон сахнасидаги инъикоси десак муболаға бўлмайди. Миллий маданият тушуншасини изохлар эканмиз миллатимиз, миллий маданиятимизни энг аввало биз яшаётган, аждодларимиз яшаб ўтган шу табаррук заминда кўрамиз.

Ота-боболаримиздан бизга мерос қолган бу замин миллий маданият билан тирикдир. Ўз маданиятини йўқотган уни унутган хеч қайси миллат узоқ яшамайди. Миллий маданият нафақат бир миллатнинг маданияти балки, умуминсоний маданият эканлигини хам унутмаслигимиз лозим.

Маданият -жамият, инсон ижодий куч ва қобилиятлари тарихий тараққиётининг муайян даражаси. Кишилар хаёти ва фаолиятининг турли ко 'ринишларида, шунингдек, улар яратадиган моддий ва ма'навий бойликларда ифодаланади. “Маданият” тушунчаси муайян тарихий давр конкрет жамият, элат ва миллат, шунингдек, инсон фаолияти ёки турмушининг о“зига хос сохаларини изохлаш учун қо“лланилади. "Маданият" арабча мадина (шахар) сўзидан келиб чиққан.

Мазкур мақола хам С.Ахмад хикояларида фойдаланилган миллий маданият бирликларига бағишланган бўлиб, унинг ички хусусиятларини ўрганишга бағишланган.

Адиб С.Ахмаднинг “Қоракўз Мажнун” хикоясида хам миллий маданият намунаси бўлган миллий тилнинг йўқотилиши қуйидаги парчада ўз аксини топган.

Қишлоқ̧дагилар товамни «Буррихон» демай, «дядя Боря» деб чақұришар экан. Бу гапларни эшитиб, кампир ер ёрилмади-ю, кириб кетмади. Боласи тушмагур-эй, куйнни хотинларнинг олдида шу гапларни айтиб уттирибди-я! Бировга сўзини бермайдиган эррайим кампирнинг шохи синди, остона хуатламай уйда муқ̧им ўтириб қ̧олди.

Хикоядан келтирилган мисолда онанинг фарзанди томонидан мухаббати сабаб унутилиши, хатто бошқа динга ўтиши хам миллий маданиятни йўқолишидан далолат беради. Миллий маданиятини йўқотган оғли хақидаги гапларни эшитиб саксон ёшли кампирнинг остона хатлаб кўчага чиқа олмаслиги, бир кечадаёқ онанинг сочлари оқариши, ўзлигини йўқотган оғлининг она тилидан айтилаётган сўзларни тушунмаслиги, мехр-мухаббатнинг йўқолиши бунинг яққол исботидир. Туғилган юртга мухаббат туйғуси уни тарк қилганига кўп йиллар бўлган. Она тили эса қадим-қадим замонлардаёқ унитилганини биргина парчадаёқ ифодаланганини кўришимиз мумкин. Онаизорнинг остона хатламай уйда ўтириши, Ватанини унутган ўғли хақидагига гапларни хазм қилолмаслиги, миллийлик ундаги буюк маданият, ўглида эса буларнинг бирортаси қолмагани онани ич-ичидан эзарди. Тахлилдан мақсадимиз остонадан ташқарига чиққан гаплар эмас балки, унинг Ватан билан боғлиқ миллий маданиятини ёритишдан иборат. Биз тахлил қилаётган остона шу юртнинг Ватаннинг остонасидир.

Ўзбек хикоячилигининг равнақига муносиб хисса кўшган С.Ахмаднинг “Буқаламун билан учрашув" хикоясидан.

Менинг кўксимда овир тош қ̧олди. Бир ярим йилдан кейин янги аср бошланади. Нахуотки шу исқирт хуам биз билан янги аср дарвозасидан кирса. Янги аср остонасида бу суприндиларни эски калишдек ечиб ташлаб кетсак құандоқ яхши булларди-я.

Келтирилган мисолда хамма замонларда хам учрайдиган табиати оғир инсон тасвири 
ёритилган. Лекин халқ бундай инсонлар билан бирга яшашни хохламас эди. Исқирт сўзи билан бежизга ифодаланмаган. Ўз отасидан воз кечган ўғилни халқ кечирмади. Бундай нобакор фарзандлар халқ учун, Ватан учун жонини фидо қилмасдан, бу мустақиллик бизга нима берди дея таъна қилган. Халқ фидоийлари буқаламунга ўхшаган инсонлар билан бирга яшашни, улар билан бирга нафас олишни, ич-ичидан истамади. Янги аср остонасига бу каби инсонлар қадам кўйса, миллий маданиятимизга, ёмонлиги эса янги аср фарзандларига таъсир қилади дея уй̆лашди. Инсонлар янги асрни янги омад ва бахт билан кутиб олишни ният қилишган эди. Бу каби инсонларнинг эски калишдек шу асрда қолиши ижобат бўлди ва бу инсон вафот этди. Хатто мурдасини хам худди хайвондек чакалакзорга кўмишди. Миллий маданият, одамийлик сифатлари бўлмаган бундай инсонларга янги аср тугул мозордан хам жой ажратишмади. Бу инсон миллийлигини йўқотган оқпадар эди.

Адиб хикояларининг яна бири “Сувлар оқиб кетди” деб номланади.

Гуудаклигидан эсида қуолгани шу. Кейин буйи чўзилиб қолганда онаси тахи бузилмаган бахмал кўрпани бузиб, унга тўн тикиб бергани, кийдириб мактабга юборгани хฺам эсида. Ўшанда онаси мактаб остонасига етмай, йўл урттасида қъараб қ̧олган эди.

Юқоридаги хикоядан келтирилган мисолда мактаб остонаси бирикмасида боланинг хаётга қадам қўйишидаги онанинг машаққатлари, миллийлигимиз акс этган. Биз биламизки, барча мамлакатларда хам фарзандлар ота-она томонидан қадрланиб, мехр туйғуси ила суғорилиб тарбияланади. Бу миллатларга тегишли бўлган маданиятлар ўз навбатида инсониятга хам боғликдир.

Янги УЗббекистон остонаси мактабдан бошланади десам, уйлайманки, бутун халқимиз бу фикрни кўллаб-кувватлайди”,- деб таъкидлаган эди Президентимиз Ш.М.Мирзиёев.

Президентимиз таъкидлаганларидек, миллий маданият инсонларда йиллар давомида шаклланади, неча-неча авлодлардан ўтиб келаётган бу қадриятлар келажак авлод тарбиясида мухим ахамият касб этади. Парчада келтирилган мактаб остонаси бирикмасида хам она мехри ила тарбияланган фарзанд юксаклик сари интилганини кўриб, фан номзоди даражасидаги фарзанднинг ўрни келса она дийдорига мехрига жавоб бера олмаслигини кўришимиз мумкин.

\section{Фойдаланилган адабиётлар:}

1.хттпс://уза.уз/уз/постс/збекистон-республикаси-президенти-шавкат-мирзиеевнингитув-30-09-2020

2.Ватанимиз келажаги учун мас'ульмиз - Халқ сўзи - Хс.уз

3.С.Ахмад Танланган асарлар. Хикоялар. “Шарқ”Нашриёт матбаа контсерни бош тахририяти Тошкент-2000 


\title{
РУС ТИЛШУНОСЛИГИДА СИНОНИМ ЛУҒАТЛАРНИНГ ШАКЛЛАНИШ БОСКИЧЛАРИ
}

\author{
Мирханова Гуландом Рустамовна \\ Бухоро Давлат университети ўқитувчиси, \\ мустақил тадқиқотчи
}

\begin{abstract}
Аннотация. Мазкур мақолада синоним сўзлар, уларнинг ўрганилиши хамда рус тилшунослиги тарихида яратилган синонимик луғатлар хақидаги фикрлар баён этилган.

Таянч сўзлар: лексикография, ўқув луғатчилиги, рус луғатшунослиги, араб луғатшунослиги, синонимик луғатлар.
\end{abstract}

Маълумки, дунё тилшунослигида синоним сўзлар луғатларининг турли шакллари учрайди. Рус тилшунослигида синоним луғатларнинг шаклланиши узоқ даврларга бориб тақалса-да, бу тоифадаги илк луғатлар фақатгина XVIII аср охирларидан учрайди. Мазкур луғатларнинг юзага келиши Россияда илм-фан тараққиёти, империянинг давлат тили - рус тилининг бой имкониятларини очиб бериш, адабий тилни ривожлантиришга эътибор ортган даврга тўғри келади. Рус тилида яратилган синоним луғатлар тараққиётида тўрт босқич фарқланади:

1. Синонимлар гурухини тузишга асосланган илк луғатлар. Бу босқичга куйидаги луғатларни киритиш мумкин: 1) Д.И.Фонвизиннинг 1783 йилда “Опыт российского сословника" номи билан “Собеседник любителей Российского слова” журналининг I, IV ва X сонларида чоп этилган луғати. Луғат лексикографик нашрга қараганда кўпроқ публицистик қўлланмани эслатган. Луғат корпуси алифбо тартибига риоя қилинмаган холда тартибланган 32 та синонимлар қаторидан таркиб топган бўлиб, 1866 йилда алохида китоб сифатида нашр этилади; 2) П.Ф.Калайдовичнинг 1818 йилда нашр этилган 77 та синонимик қатордан ташкил топган “Опыт словаря русских синонимов" китобининг биринчи қисми ; 3) 1840 йилда психолог ва философ А.И.Галич тахрири остида чоп этилган "Рус синонимлари луғати ёки гурухлари" луғатининг биринчи қисми. Луғат 226та луғат мақоладан ташкил топган бўлиб, синонимик қаторлар ажратилган ва ўзаро маънодош сўзларнинг этимологияси, қўлланиш ўринлари, услубий хосланишига доир хусусиятлари изохланган. 4) 1890 йилда Н.Абрамовнинг хажман унча катта бўлмаган “Русча синонимлар ва маъно жихатидан яқин иборалар луғати” нашр этилди. Луғат синонимларнинг шунчаки гурухларга ажратилган оддий рўйхати эди, бироқ ўз даврида ундан мукаммалроқ кўлланманинг йўқлиги боис Н.Абрамовнинг мазкур синонимлар ўқув луғати бир неча бор қайта нашр қилинган ва узоқ йиллар давомида таълим масканларида (1915 йилдан 1994 йилга қадар) асосий қўлланма вазифасини ўтаган. (13)

2. Мактаб ўкувчилари учун яратилган соф ўқув характеридаги синоним луғатлар. XX аср бошларидан рус тили синонимик луғатлар тараққиётида сезиларли силжиш кузатила бошлади. Уқув қўлланма сифатида учта луғат нашр этилди: 1) В.Д.Павлов-Шишкин ва П.А.Стефановскийнинг "Рус адабий тилининг синоним ўқув луғати" ; 2) В.Н.Клюеванинг "Рус тилининг қисқача синонимлар луғати”; 3) 2800 га яқин синонимик қатор берилган "Рус тилининг синонимлар ўқув луғати”, унда мавжуд.

3. Хажман катта академик ўқув синонимик луғатлар. Бундай луғатлар, одатда, олий ўкув юрти талабалари, махсус соха вакиллари - ёзувчи, журналист, таржимонлар учун мўлжалланган бўлиб, анча мукаммаллиги билан шу турдаги бошқа луғатлардан фарқланади. Уларнинг ичида энг машхури 3.Э.Александрованинг хозирга қадар бир неча марта қайта-қайта нашр этилган "Рус тилининг синонимлар луғати” дир. Луғат журналист, телебошловчилар ва ижодкорларга мўлжалланган бўлиб, маъно жихатидан яқин бўлган синонимлар ўз қаторлари билан изохсиз тартибланган. Дастлабки учта нашрда 9000га яқин, кейинги нашрларда 11000га яқин синонимик қатор ажратилган.

1970-71 йилларда Россия Фанлар академиясининг Рус тили институти ўқув луғатчилиги сектори ходимлари жамоаси томонидан А.П.Евгенъева рахбарлигида замонавий рус адабий тили синонимларини илк марта тўлиқ қамраб олган ва уларнинг ўзига хос хусусиятлари, рус адабий нутқида ишлатилишўринлари тавсифлаган 2 жилддан иборат “Рус тилининг синонимлар луғати” нашр этилади. Аввалги луғатлардан фарқланиб мазкур луғатда синонимлар қатори гурухларга ажратилиб тавсифланади ва хар бир сўзга бадиий асарлардан олинган расмлар, мисоллар келтирилади. Тавсифларда сўзнинг семантик хусусиятлари, эмоционал-экспрессив 
бўёғи, услубий хослиги билан боғлиқ фарқли жихатлари акс этади. 1975 йилда А.П.Евгеньева тахрири остида “Синонимлар луғати. Уқув маълумотнома” си нашр этилди. Ушбу юқоридаги икки жилдли луғат негизида, бадиий асарлардан олинган расмларни чиқариш йўли билан ихчамлаштирилган холда битта китоб холида чоп этилади.

4. Замонавий ўкув синонимик луғатлар. 1997 йил Россия Фанлар академиясининг В.В.Виноградов номидаги рус тили институтида Ю.Д.Апресян рахбарлигида рус тилининг янги синонимлар изохли луғати нашр этилади. Луғат тилни интеграл тавсифлаш (грамматика ва сўз бойлигини изчил тавсифлаш) тамойилларига мувофиқ тузилган ва "оламнинг энг содда лисоний манзараси"ни акс эттиришга қаратилган. Луғатда синоним сўзларнинг ўзаро семантик, прагматик, коммуникатив ва бошқа ўхшашлик ва фарқли жихатлари хамда ушбу фарқларнинг тўлиқ ёки қисман мўтадиллашганлиги хусусидаги маълумотлар максимал даражада тўлиқ қамраб олинган.

Хулоса қилиб айтганда, илк босқичга оид синонимлар луғатлари, асосан, рўйхатлардан ташкил топгани, сўзлик мавзувий тамойил асосида тартиблангани, нотиқликка ўргатиш, сўзнинг нозик маъно фарқларини англаш ва нутқда улардан ўрнида фойдаланиш учун хизмат қилгани билан характерланса, кейинги босқичларга мансуб синоним луғатларда рўйхатларнинг такомиллашиб боргани, шунчаки рўйхатлар эмас, уларнинг изохи хам берилгани, изохларда синонимларнинг тарихий тараққиёти, оғзаки нутқ ёки адабий тил учун хосланганлиги, ўз ёки ўзлашма қатлам сўзи эканлигига доир маълумотлар хам акс этгани кузатилади.

\section{Адабиётлар:}

1. Расулов. Р. Умумий тилшунослик. - Тошкент: Фан ва технология, 2007.

2. Mirxanova G.R. The role of educational lexicography in the world language system and the study of synonymous dictionaries. Modern scientific challenges and trends: a collection scientific works of the International scientific conference (30th April, 2020) - Warsaw: Sp. z o. o. "iScience", 2020.

3. Бахриддинова Б.М. Ўзбекистонда ўкув луғатчилиги: лингвистик асослари, тарихи ва истиқболлари: Филол.фан... доктори (DSc) дисс. - Самарқанд. 2020., -252 б.

4. Волошина О.А. Речь божественная и человеческая в словаре-тезаурусе Амаракоша // Индоевропейское языкознание и классическая филология. 2016. №1. URL: https://cyberleninka. $\mathrm{ru} /$ article/n/rech-bozhestvennaya-i-chelovecheskaya-v-slovare-tezauruse-amarakosha

5. http://rushist.com/index.php/philosophical-articles/-dialogi-platona

6. Mirxanova G.R.The importance of lexicography in the development in education. Инновационное развитие науки и образования. Международная научно-практическая конференция, Казахстан, 2020. 


\title{
ОСНОВНЫЕ ИНТЕРАКТИВНЫЕ ТЕХНОЛОГИИ ОБУЧЕНИЯ ИНОСТРАННОМУ ЯЗЫКУ
}

\author{
Шоазизова Азиза \\ Преподователь кафедры Узбекский язык и \\ иностранные языки Ташкентский Финансовый Институт
}

\begin{abstract}
Annotation: The article describes the methods and techniques of selecting teaching materials for English lessons using information communication technologies. Multimedia programs and all kinds of apps, effective internet sites which could be used during foreign language classes are also described here.
\end{abstract}

В преподавании иностранных языков появляется необходимость использования таких систем, методов и технологий обучения, которые будут обеспечивать развитие познавательных, коммуникативных и многих других способностей учащихся.

В условиях компетентностного подхода они направлены на развитие познавательных пособностей учащихся и их активность в процессе обучения.

Основная образовательная ценность информационных коммуникационных технологий в том, что они позволяют создать интерактивную среду обучения с почти неограниченными потенциальными возможностями. В отличие от обычных технических средств обучения информационные коммуникационные технологии позволяют не только насытить обучающегося большим количеством знаний, но и развить интеллектуальные, творческие способности учащихся, их умение самостоятельно приобретать новые знания, работать с различными источниками информации. . На современном этапе развития образовательного процесса среди первоочередных стоят задачи резкого повышения качества обучения, мотивации учения, преодоления накопившихся деструктивных явлений.

Использование информационных технологий в обучении иностранным языкам изменило подходы к разработке учебных материалов в значительной мере по этой дисциплине. В отличие от традиционного, интерактивное обучение на основе мультимедийных программ позволяет более полно реализовать целый комплекс методических, дидактических, педагогических и психологических принципов, делает процесс познания более интересным и творческим. Возможности учитывать уровни языковой подготовки обучаемых и разрабатывать задания различной степени сложности в рамках одной программы служат хорошей основой для реализации принципа индивидуализации и интерактивного подхода обучению иностранным языкам и всем другим дисциплинам. При этом обеспечивается соблюдение принципа сложности заданий, учитывается индивидуальный темп работы каждого обучаемого.

Использование новых информационных технологий в обучении иностранным языкам предполагает активную позицию самого обучаемого в процессе усвоения знаний. Новый вид познавательной деятельности исключает пассивное восприятие информации и способствует развитиюпознавательнойсамостоятельностиучащихся, формированиюумений самостоятельно пополнять знания, осуществлять поиск и ориентироваться в потоке информации .

Мультимедиа - это совокупность программно-аппаратных средств, реализующих обработку информации в звуковом и зрительном виде. Мультимедиа передает звук, тексты и изображения по местным, региональным и глобальным сетям .Графика, анимация, фото, видео, звук, текст в интерактивном режиме работы создают интегрированную информационную среду, в которой обучающийся обретает качественно новые возможности. Некоторые интерактивные технологии представляют собой неразделимый симбиоз аппаратного и программного обеспечения.

Примером служит Language Teacher Partner - аппарат, используемый для интерактивного обучения английскому языку и проверки знаний. Он содержит подробный грамматический справочник и туристический разговорник на 7 европейских языках и встроенный образец экзамена TOEFL. Синтезатор английской речи с возможностью регулировки тональности и частоты воспроизведения в сочетании с системой интерактивной фонетической практики позволяет услышать и отработать правильное произношение слов и фраз.

Мультимедийные программы одновременно стимулируют у обучаемого сразу несколько каналов восприятия, лучше поддерживают его внимание, способствуют снижению. В свою очередь, сочетание зрительного образа, текста и звукового ряда предоставляет большие 
возможности для комплексного развития навыков речевой деятельности учащегося на иностранном языке. Этот процесс приобретает интерактивный характер благодаря возможности двусторонней связи, диалога с компьютером, когда обучаемый и компьютер могут задавать друг другу вопросы, получать на них ответы, когда компьютер может давать корректирующие подсказки и к нему можно обратиться за помощью .

В этом смысле Интернет тоже очень помогает и обусловлена несколькими моментами. Во-первых, поскольку Интернет представляет собой безграничный источник информации, он позволяет преподавателю сэкономить время на поиске необходимого современного аутентичного материала и сосредоточиться на методической работе по обработке текстовой, звуковой, визуальной информации.

Во-вторых, Интернет предоставляет большие возможности для творчества, т.к. при использовании онлайнового материала преподаватель становится автором: сам определяет цели, разрабатывает структуру урока, изобретает новые виды работ. При этом подготовленный преподавателем материал будет привлекательным для студентов, поскольку будет ориентирован на конкретные цели и задачи .Использование Интернета позволяет повысить эффективность обучения иностранному языку за счет повышения мотивации студентов, овладения навыками критического осмысления аутентичных текстов и проведения исследовательской работы в сети, в целом погружения в языковое

пространство. Таким образом, интерактивные методы обучения - это создание педагогом условий, в которых учащийся сам будет открывать, приобретать и конструировать знания. Это является принципиальным отличием целей активного обучения от целей традиционной системы образования.

\section{Список литературы}

1. Селевко, Г.К. Современные образовательные технологии. Учебное пособие для педагогов вузов и институтов повышения квалификации / Г.К.Селевко. - М., 2008.

2. Пассов, Е.И., Цель обучения иностранному языку на современном этапе развития общества. Общая методика обучения иностранным языкам. Хрестоматия / Е.И. Пассов, В.П. Кузовлев, В.С. Коростелев. - М.:Просвещение, 2011.

3. Григальчик, Е. К. Обучаем иначе. Стратегия интерактивного обучения / Е.К. Григальчик, Д.И. Губаревич. - Минск, 2003. - с. 13-14

4. Полат, Е.С. Новые педагогические технологии /Пособие для учителей-М., 2007. 


\title{
OTA - ONALARDA TARBIYAVIY BILIMLARNI SHAKLLANTIRISH VOSITALARIDA PSIXOLOGIK TAVSIFLANISHI
}

\author{
Ernazarova Shahnoza Nizomiddin qizi \\ Zafarobod tumani 14-maktab amaliyootchi psixologi \\ Avalova Kamola Sobirovna \\ Arnasoy tumani 19-maktab amaliyotchi psixologi \\ Urisheva Mohira Ibrohim qizi \\ Zomin tumani 46-maktab amaliyotchi psixologi \\ Jizzax viloyati
}

Annotatsiya: ota-ona, bola, ta'lim, tarbiya, ahloq, oila, barkamol shaxs

Аннотация: родители, воспитание, пристойность, семья, совершенный личность

Annotatsiya: parents, child, education, educate, morals, family, perfect, person

Yoshlarni milliy istiqlol g`oyalari ruhida tarbiyalashda oila mafkurasi, ma'naviyati muhim ahamiyat kasb etadi. SHunga ko'ra oilaning muqaddasligi, ota-ona va farzandning burchi, tejamkorlik, sabrqanoat, o'zaro muamola munosabatlari, uy tutish, mehnat tarbiyasiga ham ahamiyat beriladi.

Shu sababli yoshlarni tarbiyalashda ota-onaning vazifalariga:

- oilada sog'lom muhitni yaratish, milliy ruh va turmush tarzini hisobga olish, farzandlar uchun ota-ona har tomonlama o'rtak bo'lishi, farzandlarning ota-onasiga, Vataniga mehr-muhabbat tuyg'usini shakllantirish, o'zaro g'amxo'r bo'lishni ta'minlash;

- farzandlariga chuqur axloqiy bilim asoslarini berish, ma’rifatli va ma’naviyatli kishilar bo 'lib etishishlarini ta'minlash;

- farzandlarning ma’naviy barkamol va jismonan sog 'lom bo 'lishlari uchun iqtisodiy va ijtimoiy muhitni yaratish;

- farzandlarda tejamkorlik va ishbilarmonlikning ma'naviy-axloqiy tomonlarini shakllantirish;

- $\quad$ sanitariya-gigienik, ekologik ko'nikmalarni singdirish, diniy aqidaparastlik, ichkilikbozlik, giyohvandlikka qarshi tarbiyani amalga oshirish kabilar kiradi.

$\mathrm{Bu}$ haqda psixologiya fanlari doktori, professor Vasila Karimova «Ham jismonan, ham ta'nan va ruhan $\operatorname{sog}^{6} l$ lom odam turli g'alamislarning kirdikorlariga uchmaydi, o' $\mathrm{z}$ yurti, Vatani va xalqi manfaati yo'lida halol mehnat qiladi» - deydi.

Maqsadli oilaviy tarbiya shaxsni shakllantirishning boshqa omillaridan sifat jihatdan shu bilan farq qiladiki, tarbiyalovchi oila o'z oldiga ongli sur'atda ma'lum bir maqsad qo'yadi va shu maqsadga erishish uchun intilib, uni amalga oshirish vositalarini topadi. Tarbiya shaxsni muayyan yo"nalishda shakllantirfish bilan turli odamlarning bir-biriga ta'sir ko'rsatadigan ijtimoiy munosabati hisoblanadi.

G'oyaviy tarbiyada tarbiyalanuvchilarning rivojlanishini yoshini, tipologik va individual xususiyatlarini hisobga olinishi qator pedagogik muammolarning oldini oladi. Masalan: g'oyaviy jihatdan bilimi sust bo 'Igan ota-onalar farzandiga tarbiya berishda xatoliklarga yo"1 qo"yishadi va natijada bola yoshi osha borgan sari ota-onadan uzoqlasha boradi hamda o'smirlik davrida buzg'unchi g'oyalarga nisbatan moyilligi kuchayib boradi. Ayrim ota-onalar bolani fiziologik yoshini hisobga olmaydi va bu xato-kamchiliklarni ularning o'zlari anglashmaydi. SHu bilan birga oilaviy sharoiti nochor bo'lgan bola ota-onadan norozi boiib, 14-15 yoshga etganda oilasi, ota-onasidan turli kamchiliklar topib, ayblay boshlaydi, ya'ni unda muxolif fikr tug'iladi. Bu norozilik kayfiyati ulg'aygan sari jamiyatga, davlatga qarshi buzg'unchi g'oyalarga aylanishi mumkin.

Ota-onalarning g'oyaviy-tarbiyaviy bilimlarini oshirish bilan oilada farzand tarbiyasi bo'yicha quyidagi ishlarni ijobiy tomonga o'zgartirish mumkin:

Aqliy tarbiya — bolada milliy istiqlol g'oyasiga nisbatan ijobiy fikrlarni hosil qilish.

Axloqiy tarbiya - axloq ijtimoiy ong shakllaridan biridir. Axloq tamoyillari xalq ommasi tomonidan uzoq vaqt davomida shakllangan halollik, rostgo'ylik, oddiylik, kamtarinlik, o'ziga talabchanlik, oilada bir-birini hurmat qilish, bolalar tarbiyasi to ' $\mathrm{g}$ 'risida $\mathrm{g}^{6}$ amxo'rlik qilish kabi axloq normalarini $\mathrm{o}^{6} \mathrm{z}$ ichiga oladi. 
Estetik tarbiya-shaxsning estetik did va ideallarini shakllantirish, uning voqelik va san'at asarlarini badiiy idrok etish, san'at sohasida mustaqil ijod qilish qobiliyatini o'stirish, go 'zallikdan lazzatlanish va go'zallik kashf etishdir.

Har qanday narsaning ham me’yorda ko'p yoki kam bo'lishi, ushbu jarayonning buzilishiga olib keladi. Oila tarbiyasida o'ta darajada nasihatgo'ylik bolaning ota-onadan bezishiga va buzg'unchi g'oyalarning ta'siriga berilib ketishiga olib keladi. Ayniqsa, hozirgi zamon yoshlariga o'zaro teng huquqli shaxslar sifatida ular bilan muamola qilish maqsadga muvofiqdir.

Ota-ona bilan o'spirin bola o'rtasida cheklov bo'lmasligi uchun:

- ular farzandlarining o'zlariga nisbatan ishonchini suiiste'mol qilmaslik:

- yoshiga qarab bolada g'oyaviy, diniy tushunchalarni shakllantirib borish;

- arzimas xato uchun bolani qattiq urishib jazolamaslik;

- bolani tengdosh do'stlari oldida izza qilmaslik;

- bolani do'stIariga nisbatan mumkin qadar moddiy jihatdan kam qilmaslik;

- bolaga shaxs sifatida muomala qilish lozim. Ota-onaning naning ijobiy tarbiyaviy usullari o'z natijasini berishi kerak:

- ona mehr beruvchi;

- to'g'ri yo'lga yo'naltiruvchi;

- bilim beruvchi;

- jasurlikka yo'naltiruvchi;

- maqsadga yo'naltiruvchi;

- ma'rifatga boshlovchi va boshqa fazilatlari bolani buzg'unchi g'oyalardan himoya qilib, uni barkamol irison bo'lib etishishida asosiy omil boiib xizmat qiladi. Muhim masalalardan biri oilaning o'zini buzg'unchi g'oyalardan himoya qilishning metodlaridan oqilona foydalanishga bog'liq.

\section{Foydalanilgan adabiyotlar ro'yxati:}

1. Alharov I.Sh., Mamatqulova R., Norqulov D. Oila tarbiyasi asoslari. - T.: "G'ofur G'ulom nomidagi nashriyot - matbaa ijodiy uyi", 2009. - 142 b. 11.

2. Beknazarov J. Tabiiylik va sun'iylik: Chegara qaerda? // “Tafakkur” jur. - T.: 2006. - №2. - B.

3. Durdonalar xazinasi: hikoyatlar, masallar, rivoyatlar, nasihatlar, hikmatlar, latifalar // Jamoatchilik asosida muharrir: M.Qoriev. - T.: "Sharq", 1999. - 192 b.

4 . Isroilov A. Giyohvandlik umr zavoli. Ommabop nashr. - T.: "Fan”, 2007. - 28 b. 


\title{
ОСОБЕННОСТИ ПРОЯВЛЕНИЯ СТРЕССА И ЕГО ПРОФИЛАКТИКА У СТУДЕНТОВ ВО ВРЕМЯ СДАЧИ ЭКЗАМЕНАЦИОННОЙ СЕССИИ
}

\author{
THE CHARACTERISTICS OF THE MANIFESTATION OF STRESS AND ITS \\ PREVENTION OF STUDENTS DURING THE DELIVERY OF THE EXAMINATION \\ SESSION
}

\author{
Yusupov Bakhadir \\ Jumoboyev Dilshod \\ Yusupova Hurliman \\ NSPI (named after Ajinyaz) \\ Karakalpakstan, Nukus
}

\begin{abstract}
Аннотация: в работе проанализированы особенности проявления стресса у студентов во время сдачи экзаменов в период экзаменационной сессии, а также направления снижения и профилактики стрессовых ситуаций.

Ключевые слова: стресс, стрессовый фактор, стрессоустойчивость, экзаменационный стресс, экзаменационный невроз, психоэмоциональное напряжение, стрессовая реакция, саморегуляция.
\end{abstract}

Abstract: the paper analyzes the features of stress manifestations in students during exams during the examination session, as well as the direction of reducing and preventing stress situations.

Keywords: stress, stress factor, stress resistance, examination stress, the examination neurosis, psychoemotional tension, stress reaction, self-regulation. человека, так как оказывают влияние на его поведение, здоровье, работоспособность, а также взаимоотношения с окружающими.

Сдача экзаменационной сессии сопряжена с огромными умственными и эмоциональными нагрузками, большой психической напряженностью и ответственностью.

Изучением проблемы стресса и стрессоустойчивости занимались как отечественные, так зарубежные исследователи, такие как Ф. Б. Березин, Дж.

Гринберг, Л. А. Китаев-Смык, Г. Селье, Ю. Л. Ханин и другие.

Человек с течением времени приспосабливается к условиям, вызывающим психофизиологическое напряжение. Такое напряжение называется стрессом. В общем виде стресс - это реакция организма на действие какого-либо фактора, а стрессовый фактор - это любое воздействие на организм, вызывающее реакцию напряжения.

В. В. Марков приводит пять стадий развития стресса, связанного с профессиональной деятельностью. На первой стадии появляется ощущение тревоги и некоторого напряжения; на второй - прибавляется чувство усталости и отчуждения (с этого момента начинается депрессия); на третьей - возникают физиологические реакции: несколько возрастает сердцебиение и повышается давление, появляются признаки нарушения пищеварительной системы, тупые боли в области живота; следующая, четвертая стадия, когда человек осознает начало болезни, и последняя, пятая стадия, когда человеку ставится диагноз болезни, причиной которой явился стрессовый фактор [1].

Экзаменационный стресс занимает одно из первых мест среди причин, вызывающих психическое напряжение у студентов. Во время сдачи экзаменов студенты сталкиваются с различными стрессовыми ситуациями, поскольку за короткий промежуток времени необходимо повторить большой объем материала, сдать несколько предметов, общаться с различными экзаменаторами. Экзаменационный невроз характеризуется различными нарушениями вегетативных функций: изменением электрического сопротивления кожи, ее температуры, потоотделения, частоты сердечных сокращений, артериального давления, сужением или расширением кровеносных сосудов, частоты дыхания, расстройством пищеварительной системы, выделением слюны, изменением диаметра зрачка, работы сфинктеров, меняется электрическая активность мозга, гомеостаз, основной обмен, у девушек часто наблюдается расстройство менструального цикла. Чаще всего обучающиеся отмечают состояние тревоги и депрессии, быструю утомляемость, нарушение сна. При сильном стрессе наряду с перечисленными изменениями меняется общее поведение человека, возникает общая реакция 
возбуждения, проявляющаяся в беспорядочных, некоординированных движениях, жестах, сбивчивой и неясной речи. При чрезмерном стрессовом воздействии наблюдается обратная реакция - общее торможение, скованность, отказ от деятельности.

Изменить предэкзаменационную и экзаменационную ситуацию, уменьшить интенсивность подготовки, процедуру проведения экзамена невозможно, однако возможно помочь созданию позитивного эмоционального настроя студентов на экзамен, снизить экзаменационные страхи, тревоги, обучить эмоциональной саморегуляции при сдаче экзаменов, тем самым способствовать сохранению психологического здоровья учащихся. Исследования Г. Селье показали, что стресс в небольшом количестве является полезным для человека, так как содействует его приспособлению к окружающей реальности. Тем не менее, если человек оказывается в сильном стрессовом состоянии, которое длится продолжительное время, то происходит перегруз адаптационных возможностей человека, что приводит к различным «поломкам» в организме человека [2].

Кроме того, как в быту, так и в научной литературе существует такое понятие как стрессоустойчивость, характеризующее не состояние стресса, а подверженность человека стрессу.

Ф.Б. Березин отмечает, что стрессоустойчивость является интегративным свойством личности, включающим в себя взаимодействие эмоционального, волевого, интеллектуального и мотивационного компонентов психической деятельности человека, которые обеспечивают оптимальное успешное достижение цели деятельности в сложной эмоциональной обстановке [3].

Стрессоустойчивость определяет успешность социального взаимодействия индивида, характеризуется эмоциональной стабильностью, высоким уровнем саморегуляции, низким уровнем тревожности, и высоким уровнем психологической готовности к стрессу.

Следует отметить, что в период экзаменационной сессии у студентов наблюдаются выраженные нарушения вегетативной регуляции сердечнососудистой системы. Продолжительное и очень сильное эмоциональное напряжение может приводить к активации симпатического или парасимпатического отделов вегетативной нервной системы, а также к развитию переходных процессов, сопровождающихся нарушением вегетативного гомеостаза и повышенной лабильностью реакций сердечнососудистой системы на эмоциональный стресс.

Все это приводит к тому, что во время экзамена существенно увеличивается частота сердечных сокращений, повышается артериальное давление, увеличивается уровень мышечного и психоэмоционального напряжения. Однако, даже после сдачи экзамена физиологические показатели не сразу возвращаются к исходной норме, для этого может потребоваться несколько дней. Таким образом, экзаменационный стресс, имеющий массовый характер, представляет собой серьезную угрозу для здоровья студентов.

Важным профилактическим средством экзаменационного стресса является сразу выставленная оценка. Незнакомые помещения, преподаватели и длительное ожидание усугубляют обстановку. У учащихся с высоким уровнем тревоги во время экзаменов происходит ослабление адаптационно-приспособительных механизмов, поэтому они представляют собой потенциально невротическую группу в состоянии предболезни.

\section{Список литературы}

1. Марков В.В. Основы здорового образа жизни и профилактика болезней: учеб. пособие для студентов пед. вузов / В. В. Марков. - М.: Академия, 2001. - 320 с.

2. Селье Г. Очерки об адаптационном синдроме / Г. Селье. - М., 2010. - 437 с.

3. Березин Ф.Б. Психическая и психофизиологическая адаптация человека / Ф.Б. Березин. Л.: Наука, 1988. - 322 с.

4. Баевский Р. М. Оценка адаптационных возможностей организма и риск развития заболеваний / Р.М. Баевский, А.П. Берсенева.—- М.: Медицина, 1997.— 256 с. 


\title{
ИЖТИМОИЙ МУНОСАБАТЛАРДА САМАРАЛИ МУЛОҚОТГА ЭРИШИШНИНГ ПСИХОЛОГИК МЕХАНИЗМЛАРИ
}

\author{
И.Х. Калонов \\ ИИВ Академияси катта ўқитувчиси
}

\begin{abstract}
Аннотация: Ижтимоий муносабатлар тизимида мавжуд психологик тўсиқлар ва уларни бартараф этишда самарали мулоқотни амалга оширишнинг психологик жихатлари илмийамалий жихатдан ёритилган.

Калит сўзлар: мулоқот, касбий муомала, шахснинг индивидуал-психологик хусусиятлари, мулоқотнинг асосий босқичлари, психологик тўсиқлар, психологик алоқа ўрнатиш, психологик таъсир этиш усуллари, ижтимоий-психологик фазилатлар.

Аннотация: Существующие психологические барьеры в системе социальных отношений и психологические аспекты эффективного общения в их преодолении освещаются научно и практически.

Ключевые слова: общение, профессиональное общение, индивидуально-психологические особенности личности, основные этапы общения, психологические барьеры, психологический контакт, методы психологического воздействия, социально-психологические качества.

Resume: The existing psychological barriers in the system of social relations and the psychological aspects of effective communication in overcoming them are covered scientifically and practically.

Key words: communication, professional communication, individual psychological characteristics of the personality, the main stages of communication, psychological barriers, psychological contact, methods of psychological influence, social and psychological qualities.
\end{abstract}

Ижтимоий муносабатлар, аслида, одамнинг сиёсий муносабатларидан тортиб, унинг шахслараро муносабатлари хусусиятларини ўз ичига олган мураккаб жараёндир. Психологияга оид луғатда мулоқот тушунчасига куйидагича таьриф берилган:

Мулоқот - бу одамлар ўртасида алоқаларни ўрнатиш ва ривожлантиришнинг мураккаб, кўп қиррали жараёни бўлиб, биргаликдаги фаолиятнинг эхтиёжлари натижасида вужудга келади ва шу билан бирга ахборот алмашинуви, ўзаро алоқанинг ягона стратегиясини ишлаб чиқиш, бошқа одамни идрок этиш ва тушунишдир ${ }^{1}$.

Педагогик мулоқ̧от - билиш ёки бахолаш характеридаги ахборот алмашув жараёнида икки ёки ундан ортиқ шахс (ўқитувчи, ўқувчи)нинг ўзаро таъсирга эга фаолияти².

Шундай бўлса-да, шартли равишда мулоқотга нисбатан умумий бўлган куйидаги таърифни бериш мумкин: мулоқ̧от - камида икки кишининг ўзаро таъсир жараёни бўлиб, бу таъсир давомида ахборот алмашинади, муносабат ўрнатилади ва ривожлантирилади, тугатилади ёки коррекцияланади ${ }^{3}$.

Мулоқотнинг психологик жихатдан мураккаб эканлиги хақида Б.Д.Парыгин шундай ёзади: «Мулоқот шунчалик кўп қиррали жараёнки, унга бир вақтнинг ўзида куйидагилар киради: индивидларнинг ўзаро таъсир жараёни; индивидлар ўртасидаги ахборот алмашинуви жараёни; бир шахснинг бошқа шахсга муносабати жараёни; бир кишининг бошқаларга таъсир кўрсатиш жараёни; бир-бирларига хамдардлик билдириш имконияти; шахсларнинг бир-бирларини тушуниши жараёни.

Мулоқот жараёни шахсларнинг қизиқишлари, дунёқараши, муомала маданиятига хам боғлиқ бўлади, чунки шахслардаги ўзаро мулоқот бу табиий эхтиёждир.

Мулоқот орқали шахсларнинг биргаликда алоқа қилиш методикаси кетма-кет бўлган олти босқичдан иборат: ўзаро бир-бирини тушуниш; умумий ёки мос келадиган қизиқишларни топиш; мулоқот учун таклиф этиладиган сифат ва қабул қилинадиган принциплар; мулоқот учун хавфли бўлган сифатларни аниқлаш; индивидуал таъсир этиш ва сухбатдошга мослашиш; умумий қоидаларни яратиш ва ўзаро харакат қилишдан иборат бўлиб, бунда босқичлар

\footnotetext{
1 Краткий психологический словарь / Сост. Л.А. Карпенко; Под общ. ред. А.В. Петровского, М.Г. Ярошевского. - М., 1985. - С 213.

2 Педагогик атамалар луғати / Р.Х.Джураев ва бошқ. - Т., 2008. - Б 56.

3 Ички ишлар идоралари ходимлари фаолиятида касбий муомала: Ўкув кўлланма / Б.Н.Сирлиев, Ё.А.Фарфиев, О.А.Турсунова. - Т., 2016. - Б 6-7.
} 
кетма-кетлигига риоя қилиш тўғри таъсир этишни ташкиллаштиришда мухим ахамиятга эга. Босқичлар алоқа қилиш жараёнида амалга оширилаётган фаолиятнинг кетма-кетлигини кузатиш дастури сифатида намоён бўлиши, ўзаро таъсир йўлларини назорат этиши мумкин ${ }^{1}$.

Касбий муомала хар бир шахснинг фаолиятида мухим ўрин эгаллайди. Шунинг учун хам муомаланинг хар бир тури фаолият жараёнида иштирок этади. Инсон муомала қонуниятларига суянган холда бошқа шахслар билан муносабатга киришади. Мулоқот жараёнида шахснинг барча касбий сифатлари (хотира, диққат, идрок, сезги, тафаккур, хаёл) иштирок этади. Бу жараёнлар шахснинг мантиқий фикрлашига, воқеани ўтмишдаги вазият билан боғлашига, ўзаро солиштириш ва қиёслаш, объект ва шароитни мукаммал тарзда идрок этишига ёрдам беради.

Одамлар бир-бирлари билан муомала қилишар экан, уларнинг асосий кўзлаган мақсадларидан бири ўзаро бир-бирларига таъсир кўрсатиш, яъни фикр-ғояларига кўндириш, харакатга чорлаш, установкаларни ўзгартириш ва яхши таассурот қолдиришдан иборат.

Психологик таъсир - бу турли воситалар ёрдамида инсонларнинг фикрлари, хиссиётлари ва хатти-харакатларига таъсир кўрсата олишдир 2 .

Шунга қарамай турли хил тоифадаги, турли хулқ-атворга эга инсонлар билан мулоқотга қиришиш, уларга психологик таъсир кўрсатишда айрим тўсиқлар ёки зиддиятли вазиятларга дуч келиш холатлари кўп учрайди.

Мулоқот жараёнида объектнинг ўзига хос томонлари борлигини хам хисобга олиш лозим. Шуни айтиш жоизки, кўп холатларда девиант хулқли шахслар жамиятдаги ахлоқсиз, одобсиз ва виждонсиз кишилар бўладилар. Натижада мулоқот жараёнида хар хил психологик тўсиқлар пайдо бўлиб, кўпроқ улар сунъий равишда вужудга келтирилади.

Мулоқуот жараёнида қуйидаги психологик тугсиқлар вужудга келиши мумкин: мотивацион тўсиқлар; ақлий тўсиқлар (интелектуал); эмоционал тўсиқлар; тарбиявий жараёндаги тўсиқлар ${ }^{3}$.

Мулоқот жараёнида психологик тўсиқларни бартараф этишнинг зарурий шарти фуқаролар билан психологик алоқа ўрнатишдан иборат бўлиб, бундан кўзланган мақсад кутилаётган мулоқот жараёнида субъектнинг психик (рухий) фаолиятини жадаллаштириш, мулоқотда қўрқув ва хавотирларни олиб ташлаш хамда психологик мослашув (адаптация) жараёнини осонлаштириш имконини беради.

Шунингдек, психологик алоқа ўрнатишда бўлажак мулоқотни башорат қилиш, алоқани енгиллаштирувчи ташқи омилларни яратиш, ташқи коммуникатив сифатларнинг намоён бўлиши, умумий ва бетараф қизиқиш доираларини аниқлаш, муомаладаги оғишларни бартараф этиш ва индивидуал таъсир кўрсатиш каби босқичларда амалга оширилса, ижобий натижа беради. Хар қандай тоифадаги инсонлар билан самарали мулоқот қилиш учун чукур билим ва қуйидаги ижтимоий-психологик фазилатларга эга бўлиш керак: нотаниш шахслар билан тезда мулоқотга киришиш, уларга маъқул бўлиш; бошқа шахсларнинг гапини эшита олиш қобилиятига эга бўлиш; одамларга психологик таъсир кўрсата билиш; мулоқот жараёнида психологик тўсиқларни бартараф этиш ва хоказо.

Хулоса ўрнида шуни айтиш мумкинки, шахслараро муносабат жараёнида мулоқотнинг қонуниятлари, механизмлари хамда шахснинг индивидуал-психологик хусусиятларини инобатга олган холда амалга ошириш кўзланган натижага эришиш гарови хисобланади.

\footnotetext{
1 Филонов Л.Б. Тренинги делового общения сотрудников органов внутренних дел с различными категориями граждан. - М., 1992. - С.5-6.

2 Ички ишлар идоралари ходимлари фаолиятида касбий муомала: Ўкув кўлланма / Б.Н.Сирлиев, Ё.А.Фарфиев, О.А.Турсунова. - Т., 2016. - Б 18.

3 Ички ишлар идоралари ходимлари фаолиятида касбий муомала: Ўкув кўлланма / Б.Н.Сирлиев, Ё.А.Фарфиев, О.А.Турсунова. - Т., 2016. - Б 38.
} 


\title{
ПСИХОЭМОЦИОНАЛЬНЫЕ АСПЕКТЫ ВОЗДЕЙСТВИЯ СТРЕССА НА ЧЕЛОВЕКА И ЕГО РАЦИОНАЛИЗАЦИЯ
}

Хакимова Ирода Мухаммаджоновна Преподаватель кафедры Психология служебной деятельности Академии МВД Республики Узбекистан

Khakimova Iroda Mukhammadzhonovna

Lecturer at the Department of Psychology of Performance Academy of the Ministry of Internal Affairs of the Republic of Uzbekistan

\begin{abstract}
Аннотация. В данной статье даны основополагающие определения понятия «стресс», его роль в нашей повседневной жизни, а также связанные с механизмами психологических и физиологических изменений у человека воздействия стрессорного фактора, его положительные и отрицательные стороны и, самое главное, способ его рационализации для нивелирования его последствий.
\end{abstract}

Ключевые слова: стресс, эмоциональный стресс, психология стресса, физиология стресса, адаптация к стрессу.

Annotation. This article gives the fundamental definitions of the concept of "stress", its role in our daily life, as well as the effects of the stress factor associated with the mechanisms of psychological and physiological changes in humans, its positive and negative aspects and, most importantly, the method of its rationalization to level its consequences.

Key words: stress, emotional stress, stress psychology, stress physiology, adaptation to stress.

Проблема возникновения стресса у человека, его протекания и последствий привлекает внимание специалистов различных областей науки, от медиков до социологов и психологов. В последние годы значительно возросло число публикаций по прикладным аспектам изучения стресса, затрагивающих самые разные стороны жизни человека. ${ }^{1}$ В то же время, до сих пор не достигнуто не только концептуального, но даже терминологического единства. ${ }^{2}$ Это привело к расширению понятийного аппарата, когда под термином «стресс» стали понимать очень широкий круг явлений, что особенно четко прослеживается на примере психологического стресса.

В первой половине 20 столетия в одном из европейских журналов от 4 июля 1936 года в разделе «Письма к редактору» появилась небольшая заметка молодого ученого Ганса Селье. Заметка состояла всего из 74 строчек и называлась «Синдром, вызываемый разными повреждающими агентами». Именно эта статья означает начало концепции стресса. Чуть позже американец Уолтер Кэннон в своих классических работах по универсальной реакции «бороться или бежать» ввел термин «стресс» в физиологию и психологию. Стресс (от англ. stress - нагрузка, давление, напряжение) - неспецифическая (общая) реакция организма на воздействие (физическое или психологическое), нарушающее его гомеостаз, а так же соответствующее состояние нервной системы организма (или организма в целом). Таким образом, это определение отражает то, что на каждое требование среды организм реагирует особым напряжением. Стресс воспринимается происходящим и возникает в момент наиболее сильной реакции, выходящей из-под контроля. Проблема стресса заключается в том, что подобное проявление может быть выражено неординарно, сдержанно или вовсе не проявляться. При этом, стресс является одной из наиболее распространенных причин неблагополучия, страданий и неудач любого человека, потому, что современный стиль жизни - это постоянная спешка, нервы, эмоции. Ганс Селье подчеркивал, что не надо этого бояться, стресс является обязательным компонентом жизни человека. Он может, как снижать, так и повышать устойчивость организма. Стресс проявляется и в любви, и в творчестве, безусловно, приносящих удовольствие и защищающих от ударов жизни. Радость, конечно, в исключительных случаях, приводит к трагическим последствиям,

\footnotetext{
1 Леонова А.Б. Основные подходы к изучению профессионального стресса // Вестн. Моск. ун-та. Сер. 14. Психология. - 2000. - № 3. - С. 4-22.

2 Бодров В.А. Система психической регуляции стрессоустойчивости человека-оператора // Психол. журн. 2000. - T. 21, № 4. - C. 32-40.
} 
в большинстве же случаев она стимулирует к жизни.

В 30-50-е годы XX века Г. Селье разработал биологическую, или, как ее еще называют, физиологическую, теорию стресса, основное положение которой гласит, что стресс есть неспецифический ответ организма на любое предъявляемое ему требование. ${ }^{1}$ Стресс, сказывающийся положительно на активности организма, был назван Г. Селье эустрессом. Избыточно сильные воздействия и требования ситуации могут сопровождаться возникновением дистресса, ухудшающего состояние и поведение человека. Биологический стресс выступает как природный защитный механизм, стереотипная реакция организма человека на любой тип воздействий. При этом в организме происходят такие изменения, как учащение сердечных сокращений, повышение кровяного давления, усиление кровообращения, активация симпатоадреналовой системы, угнетение иммунной системы, углубление, учащение дыхания, напряжение мышц, сдвиг в обмене веществ, что связано с торможением работы желудочнокишечного тракта, преобладание процессов метаболизма и т. д. В биологической адаптации, то есть в приспособлении к стрессу, можно выделить три стадии: 1) стадия тревоги - экстренной мобилизации защитных функций организма; 2) стадия сопротивляемости - устойчивого поддержания достигнутого уровня адаптированности; 3) стадия истощения - спада сил, возникновениедезадаптации. В настоящеевремя подстрессомпонимается состояние, вызванное чрезмерно сильным воздействием на организм, которое принято называть стрессором. Стресс может вызываться стрессовыми ситуациями, к которым относятся все сильные физические и нервно-психические нагрузки, в том числе чрезвычайно тяжелая работа, охлаждение и перегрев, недостаток кислорода во вдыхаемом воздухе, гипогликемия, заболевания, операции, раны, шумовое воздействие, внезапный испуг, беспокойство, боль и гнев.

Состояние стресса, возникающее в экспериментальных условиях у некоторых людей, выражается в дезорганизации интеллектуальных процессов и поведения. Исследование природы стрессовых состояний показало, что стрессовое состояние может наступить в результате различных отрицательных воздействий: при неблагоприятных социальных условиях и отношениях (положение в обществе и рабочем коллективе), при травмирующем эмоциональном или психическом воздействии (потеря близкого человека, обида, унижение, ссора), при болевом воздействии или угрозе его (оперативное вмешательство, болевое наказание), в ситуации повышенной моральной или материальной ответственности (аварии на производстве, управление транспортом и т. д.). ${ }^{2}$

Первоначально под эмоциональным стрессом понималась ситуация, порождающая сильные эмоции. Концепция стресса ввиду своей направленности на целостное понимание адаптивных реакций организма привлекла внимание специалистов по разработке режимов жизнедеятельности человека в экстремальных условиях. Будучи увлеченными изучением исключительно неблагоприятных для организма проявлений стресса, они обозначали этим термином те адаптационные эмоциональные реакции, которыми сопровождались вредные для организма физиологические и психофизиологические изменения. ${ }^{3}$ Соответственно, под эмоциональным стрессом понимались аффективные переживания, сопровождающие стресс и ведущие к неблагоприятным изменениям в организме человека. Когда же накопились сведения о существовании большого круга физиологических и психических реакций, сходных при отрицательных и положительных эмоциональных переживаниях, то есть о том, что неспецифичность проявлений собственно стресса сочетается со специфически дифференцированными эмоциями, под «эмоциональным стрессом» стали понимать широкий круг изменений психических проявлений, сопровождающихся выраженными неспецифическимиизменениямибиохимических, электрофизиологическихидругихкоррелятов стресса. ${ }^{4}$ Психологический стресс принадлежит к тем психологическим явлениям, которые называют психическими состояниями и под которыми понимают целостное своеобразие всех процессов, происходящих в психике человека в данный момент или за определенный отрезок времени. ${ }^{5}$ По мнению А.М. Столяренко, нельзя сводить психологический стресс только лишь

\footnotetext{
Селье Г. Стресс без дистресса / Пер. с англ.; общ. ред. Е.М. Крепса. - М.: Прогресс, 1979. - 124 с.

2 Гельгорн Э., Ауфборроу Дж. Эмоции и эмоциональные расстройства - М.: Мир, 1996. - 254 с.

3 Суворова В.В. Психофизиология стресса. - М.: Педагогика, 1975. - 318 с.

${ }^{4}$ Кассиль Г.Н. Внутренняя среда организма. - М.: Наука, 1978. - 224 с.

${ }^{5}$ Столяренко А.М. Экстремальная психопедагогика. - М.: ЮНИТИ ДАНА, 2002. - 75 с.
} 
к эмоциональной реакции. Эмоция - лишь одна из характеристик психической деятельности, носящей всегда целостный характер и включающей мотивационные, познавательные, волевые и психомоторные компоненты. Отсюда следует, что термины «эмоциональный стресс» и «психологический стресс» не совсем корректно отождествлять друг с другом, понимая, что психологический стресс - это системная психологическая реакция на ситуацию.

Что нужно делать? Как снизить уровень стресса в организме? Нередко используется термин рациональная терапия среди психологов и психотерапевтов. Рациональная терапия издавна применяется для уменьшения эмоционального стресса. Рациональная терапия может быть использована в комплексе с другими методами на заключительном этапе коррекции эмоционального стресса, когда общий уровень возбуждения уже снижен до приемлемого уровня. Высокотревожным людям рациональная психотерапия помогает снижать субъективную значимость ситуации, переносить акцент на осмысление деятельности и формирование уверенности в успехе, а лицам с низким уровнем тревожности она, напротив, помогает повышать внимание к мотивам деятельности, усиливая чувство ответственности. Рациональная терапия помогает по-новому взглянуть на психотравмирующую ситуацию, снизить уровень эмоционального напряжения.

Литература:

1. Леонова А.Б. Основные подходы к изучению профессионального стресса // Вестн. Моск. ун-та. Сер. 14. Психология. - 2000. - № 3. - С. 4-22.

2. Бодров В.А. Система психической регуляции стрессоустойчивости человека-оператора // Психол. журн. - 2000. - Т. 21, № 4. - С. 32-40.

3. Селье Г. Стресс без дистресса / Пер. с англ.; общ. ред. Е.М. Крепса. - М.: Прогресс, 1979. - 124 c.

4. Гельгорн Э., Ауфборроу Дж. Эмоции и эмоциональные расстройства - М.: Мир, 1996. $-254 \mathrm{c}$.

5. Суворова В.В. Психофизиология стресса. - М.: Педагогика, 1975. - 318 с.

6. Кассиль Г.Н. Внутренняя среда организма. - М.: Наука, 1978. - 224 с.

7. Столяренко А.М. Экстремальная психопедагогика. - М.: ЮНИТИ ДАНА, 2002. - 75 с. 


\title{
AGRICULTURE
}

УДК. 57.086.83

\section{ВACILLUS THURINGIENSIS-ЭКОЛОГИК ПРЕПАРАТ}

\author{
Ф.А.Мустафакулова \\ Ассистент, \\ С.Н.Мирзаабдуллаева
}

Талаба.

Андижон қишлоқ хўжалиги ва агротехнологиялар институти

Маълумки, қишлоқ хўжалик экинларини зараркунанда хашаротлардан химоя қилишда фойдаланишда асосан кимёвий препаратлардан фойдаланилади. Аммо, кейинги йилларда энг долзарб муаммолардан бирига айланаётган экологик холатнинг бузилиб бориши, тупроқ микрофлораси, унинг физик кимёвий таркиби, сув хавзаларининг ифлосланиши, булар оқибатида инсонлар ва иссиқ қонли хайвонлар организмида кескин салбий оқибатлар хосил бўлаётганлиги кимёвий препаратлардан фойдаланиш имкониятларини чегараланиб бормоқда.

Бу каби муаммолар олимлар олдига зараркунанда хашаротларга қарши кураршишнинг альтернатив усулларини ишлаб чиқиш ва амалиётда кўллаш каби вазифаларни қуймокда. Худди шундай альтернатив усуллардан бири микробиологик препаратлар асосида зараркунанда хашаротларга қарши кураш хисобланади. Бу усулнинг кимёвий усулга нисбатан бир қанча афзалликлари мавжуд бўлиб, улардан куйидагиларини келтириш мумкин: экологик тозалиги, тупроқда тўпланиб қолмаслиги, уларни тайёрлаш, сақлаш, ташиш ва қўллашнинг кулайлиги, иқтисодий самарадорлиги ва айниқса иссиқ қонли хайвонларги нисбатан зарарсизлиги олимлар эътиборини тортиб келмокда.

Микробиологик препаратлар орасида Bacillus thuringiensis спора-кристалл токсин хосил қилувчи энтомопатоген бактериялари алохида ўрин тутади. Илмий манбалардан маълумки, дунёнинг бир қатор ривожланган давлатларида (АҚШ, Франция, Англия, Германия, Италия, Россия ва х.к.), шунингдек, иқтисодий ривожланмаган давлатларида хам Bacillus thuringiensis бактериялари асосидаги биопрепаратлардан самарали фойдаланиб келинмокда ва кимёвий препаратларга тўлақонли рақобатбардош альтернатив усул эканлиги исботланган.

Бациллус турингиензис гурухидаги энтомопатоген бактерия спора ва кристалл асосида тайёрланилган инсектицидли препаратларнинг янги формалари хозирда кенг тарқалган.

Хозирги вақтда қишлоқ хўжалик экинларини зараркунандалардан химоя қилишда хашаротларда касаллик туғдирувчи микробиологик препаратлардан кенг фойдаланилмокда.

Микробиологик препаратлар кимёвий препаратлардан хар томонлама фарқ қилиб, жуда кўпгига афзалликларга эга. Бу препаратлар иссиққонли хайвонлар табиатда учрайдиган фойдали хашаротларга безиёнлиги, зараркунандалар ўртасида касалликни юқтириб тарқата олиши, хашаротнинг келгуси авлодларига таъсир кўрсатиши ва бошқалар.

Хамма бактерияли препаратлар ўсимлик зараркунандаларига ичак орқали таъсир қилиш хусусиятига эга. Бу препаратлар хашаротнинг озиқланиш натижасида уларнинг ички органларига тушади. Ишчи аралашмаларни етарли холатда тайёрлашимиз, яъни қўлланилаётган бактерияли препаратнинг салмоғи белгиланган нормадан ортиқ ёки кам бўлмаслиги керак. Ўсимлик баргининг хар 2 томонига препарат бир хилда тақсимланиши лозим. Касаллик тарқатувчи препаратлар хашарот организмига озиқа орқали киради, бактерия споралари, токсинлар ичак ва ошқозон органларига тушгандан кейин хашарот фалажланади ва овқатдан қолади, хашаротлар тирик бўлган тақдирда хам ишловдан бир неча соат кейин уларнинг ўсимликка зарари камаяди. Бир неча кундан кейин хашарот секин аста нобуд бўла бошлайди.

Шуни айтиш лозимки, хашаротнинг биопрепаратларга нисбатан чидамлиги ёшига қараб ўзгаради, яъни кичик ёшдаги қуртлар биопрепаратлар таъсирига берилувчан бўлади. Аксинча, катта ёшдаги қуртларнинг чидами юқори бўлиб, нобуд бўлмайди, аммо унинг келгуси авлодига таъсир этади.

Микробли препаратлардан самарали фойдаланиш учун бир қанча омилларга: хавонинг харорати, куёш нури, ишлатиш муддати, хашаротнинг тури, ёши, препаратга нисбатан 
таъсирчанлиги, препаратнинг неча марта қўлланиши, ўсимликка препарат эритмасининг бир текис тушиши ва бошқаларга эътибор бериш керак. Шуларга тўғри риоя қилинса юқори техник ва иқтисодий самарадорлик таъминланади.

Шунинг учун биопрепаратларни қишлок хўжалигида зараркунандаларга қарши курашда биологик самара берибгина қолмай, балки экологик, социологик самарадорликлари борки, бу хусусиятлари микробиологик усулнинг келажагидир.

Микробли препаратларни ўз вақтида тўғри қўлланилса кутилган натижага эришиш мумкин. Бунда хосилни зараркунандалардан сақлаб қолиш билан биргаликда табиатдаги экологик вазият мутаносиблиги сақланади, атроф - мухитнинг мусаффолиги таъминланади.

\section{Фойдаланилган адабиётлар}

1. Хужамшукуров Н.А. Влияния биопрепарата Antibac Uz на Helicoverpa armigera Hb. ВЕСТНИК НГУ (Вестник Новосибирский государственный университет), Россия (в печати).

2. Khujamshukurov N. Qobilov G. Influence of salinity on growth, development and symbiotic properties of legumes, rhizobia symbiosis of alfalfa in vegetation experiments. International Journal of Biology Research. India (in press).

3. «Микроорганизмы и плодородие». Ж.Войнова-Райкова, В.Ранков, Г.Ампова. Издательство «Агропропиздат» Москва-1986 год.

4. Выживаемость фитопатогенных бактерий в природе. И.В.Воронкевич. Из-во "Наука" Москва-1974г.

5. Красильников Н.А. Микробы-антагонисты и антибиотические вещества в растениеводстве. Изв. АН СССР. 1953,N2, с.49-66 


\title{
ENSURING INEVITABILITY OF LIABILITY FOR CORRUPTION OFFENSES IN THE REPUBLIC OF UZBEKISTAN
}

\author{
Ismailov Bakhodir Islamovich \\ Head of the Department \\ Academy of the General Prosecutor's Office \\ Uzbekistan, DSc, Professor \\ Inoyatullaev Sadullajon Khabibullaevich \\ Senior Lecturer \\ Academy of the General Prosecutor's Office \\ Uzbekistan
}

\begin{abstract}
The article highlights the significance of legal reforms in the field of combating corruption and relevance of international cooperation in this regard. In addition, taking into account the international standards, the author develops proposals to improve the anti-corruption legislation.
\end{abstract}

Keywords: corruption, prevention, reforms, criminal liability, integrity

Uzbekistan approved the country's Development Strategy for a five-year period ${ }^{1}$ in 2017 . The Strategy included, as part of the main directions, the improvement of organizational and legal mechanisms for combating corruption, raising the level of the legal culture of the population, expanding the interaction of the state with civil society institutions and the media, as well as strengthening international cooperation in this area.

With the purpose of implementing this priority area, for the first time in the history of the country the national law "On Combating Corruption" was adopted in 2017, which defines the government policy in this regard. In 2019, the State Anti-Corruption Program was adopted for 2019-2020 years ${ }^{3}$.

Thus, within the framework of the program, the mechanisms of informing state bodies about the facts of corruption were improved, including through mobile applications, helplines and other "hot lines", the organizational and legal mechanisms for the protection of persons reporting corruption offenses have been improved.

In 2019 only, the "helplines" of the prosecutor's office received 161970 complaints, including complaints about facts of corruption. In order to facilitate immediate and timely notification of corruption offenses in the bodies and institutions of justice, a special bot "@antikorbot" has been launched.

The Law "On Combating Corruption" provides for the liability of officials, as well as employees of state bodies, non-state commercial or other non-state organizations for committing corruption offenses. The liability can be of criminal, administrative, civil and disciplinary type.

Even though the legislation of Uzbekistan does not contain the concept of corruption offenses, 13 crimes were classified as corruption offenses in order to introduce a uniform practice of classification of criminal offenses, by a joint decision of the General Prosecutor's Office and other criminal prosecution bodies (December 30, 2019). These include theft by embezzlement, fraud with the use of official position, bribery of an employee of both a non-governmental organization and a state body, an organization with state participation or a citizen's self-government body, abuse by officials of a non-governmental commercial or other non-governmental organization of their powers, taking bribe, giving bribe and mediation in bribery, as well as the legalization of proceeds from the above crimes.

Penalties such as fines, restriction of freedom, compulsory community service, deprivation of a certain right and imprisonment for up to fifteen years can be applied to persons who have committed corruption crimes. In addition, instruments, objects of crime and proceeds of crime are subject to confiscation.

\footnotetext{
${ }^{1} \mathrm{http}: / /$ lex.uz/docs/3107042\#3109624

2 http://lex.uz/docs/3088013

3 http://lex.uz/docs/4355399. Также, в 2017 году принята Государственная программа по противодействию коррупции на 2017-2018 гг. http://lex.uz/docs/3105127
} 
Over the past 3 years, within the framework of the fight against corruption in the framework of $\mathbf{3}$ 441 criminal cases, 4969 officials were brought to justice (including 2018 - 1907 officials, 2019 1339 officials, 2020 - 1723 officials). ${ }^{l}$ (see figures 1-2)

Law enforcement agencies are taking measures to ensure liability for crimes, regardless of their social status and position.

Out of 4969 officials prosecuted for corruption offenses, 97 were employees of the republican, 351 were employees of regional and 4521 were employees of district (city) departments of ministries, departments and organizations. ${ }^{2}$ (see figures 1-2)

The crimes committed and prosecuted in this regard are such crimes as theft of someone else's property by embezzlement (2 522 persons), fraud (462), bribery (567), abuse of office (237), abuse of power (82), negligence (69), official forgery (51) and other crimes (979). ${ }^{3}$ (see figures 3-4)

Law enforcement agencies pay special attention to the seizure of corruption proceeds or property in an equivalent value, proceeding from the fact that as a result of corruption crimes, significant damage is caused to the interests of society and the state. During 2018-2020, reimbursement amounted to 2 trillion 626 billion 528 million soums of damage, which accounted for 90 percent of the damage caused by corruption crimes. ${ }^{4}$ (see figures $1-2$ )

The Code of the Republic of Uzbekistan On Administrative Liability ${ }^{5}$ classifies bribery of an employee of a state body, an organization with state participation or a self-government body of citizens and illegal receipt by an employee of a state body, an organization with state participation or a selfgoverning body of citizens of material values or property benefits to the category of administrative offenses of a corruption nature. Over the past four years, over 3 thousand employees have been brought to administrative responsibility for the above offenses.

Figure 1-2
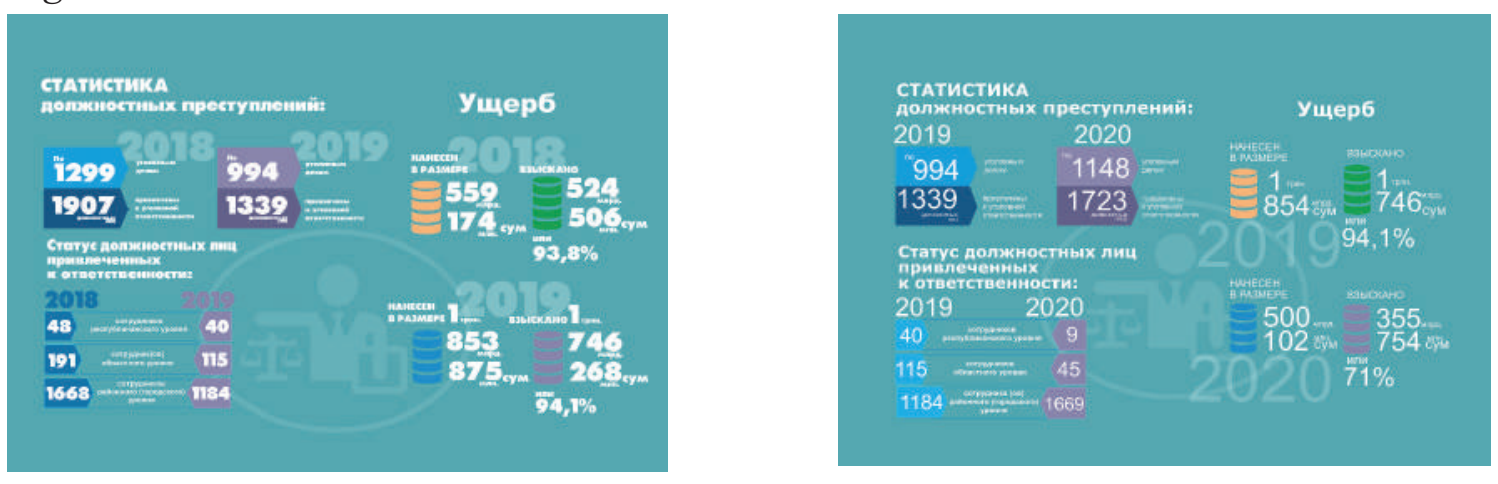

Figure 3-4
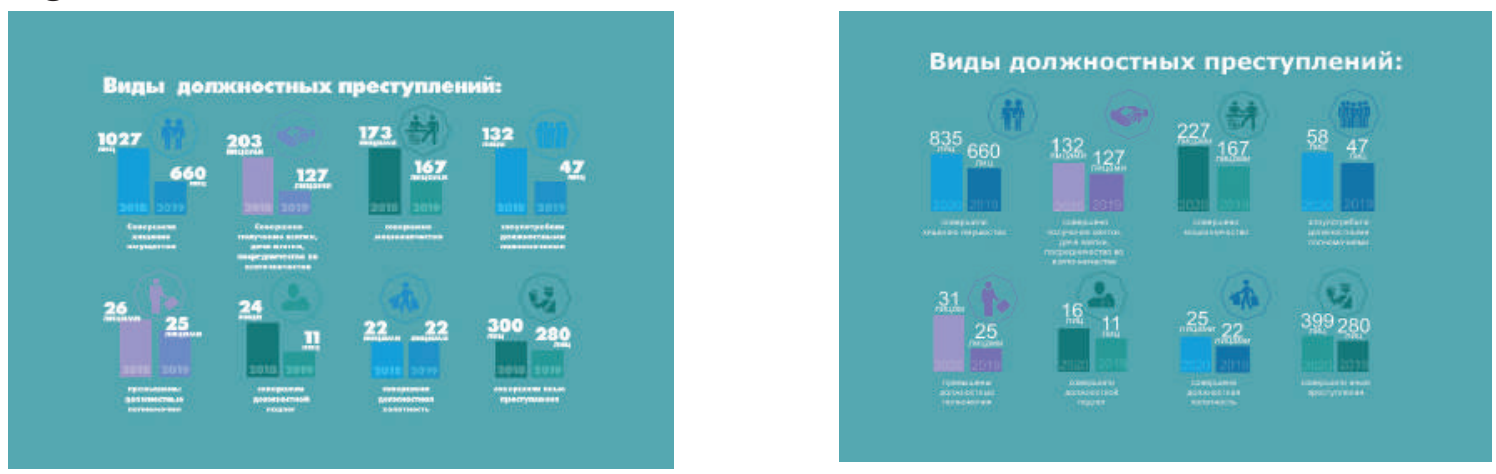

\footnotetext{
${ }^{1}$ http://prokuratura.uz/\#/korrupsiyagaqarshi. Также, статистика Генеральной прокуратуры Республики Узбекистан @uzbprokuratura

${ }^{2}$ См. там же

${ }^{3}$ См. там же

${ }^{4}$ См. там же

${ }^{5}$ http://lex.uz/docs/97661query
} 
Due to the fact that officials committed cases of violation of legislation on the prevention of conflicts of interest, the Code of the Republic of Uzbekistan on Administrative Liability was supplemented by Article $175^{8}$ providing for liability for violation of legislation on public procurement. ${ }^{1}$

Based on the requirements of Article 6 of the UN Convention against Corruption, the experience of more than 40 foreign countries, as well as the recommendations of the Organization for Economic Cooperation and Development (OECD), the United Nations Office on Drugs and Crime (UNODC), the Council of Europe $(\mathrm{CoE})$ and other international organizations, the Anti-Corruption Agency ${ }^{2}$ has been established as an authorized special body responsible for the formation and implementation of state policy in the field of preventing and combating corruption.

In terms of ensuring the inevitability of liability for corruption offenses, the Agency is empowered to send materials to law enforcement agencies to initiate criminal cases, in relation to persons in whose activities there are signs of corruption offenses, submit to state bodies, organizations and their officials mandatory warnings about the inadmissibility of corruption offenses, as well as requests on taking measures to eliminate the causes and conditions contributing to the manifestation of corruption.

Proceeding from the fact that ensuring the inevitability of responsibility for corruption crimes cannot be provided without the active participation of civil society institutions, the system and mechanisms of public oversight ${ }^{3}$, are being improved, as well as the protection of victims, witnesses and other participants in the criminal process. ${ }^{4}$

Thus, in May 2020, the Academy of the Prosecutor General's Office, with the support of UNDP, organized an international web conference for national non-governmental non-profit organizations on the interaction of state bodies and non-governmental organizations in the fight against corruption, at which experts from Kazakhstan, Latvia, Russia and Slovenia, representing national branches of the international organization Transparency International informed the participants about their experience in exercising public oversight in the field of public procurement, compliance with ethical standards by civil servants, checking their income declarations, conducting anti-corruption expertise of regulatory legal acts and many other issues related to the participation of the civil sector in promoting integrity and "zero" tolerance to corruption.

Based on the analysis of best foreign practices (Great Britain, USA, Italy, Singapore, France, Germany, etc.), a Government Act was adopted, which provides for the encouragement of persons who reported corruption offenses or otherwise provided assistance in the fight against corruption. ${ }^{5}$

Law enforcement agencies pay special attention not only to issues of ensuring the inevitability of punishment for corruption offenses, but also to issues of early prevention of illegal actions of officials.

In 2020, the prosecution authorities carried out 15021 inspections within the framework of supervision measures for compliance with the rule of law, 22783 protests were brought in, 11238 submissions (requests) were made, 13460 decisions were issued, 19359 warnings were announced (in civil cases and administrative cases - 4814, in economic cases - 1641).

In ensuring the inevitability of liability for corruption offenses, a significant focus is given on the implementation of international anti-corruption standards in the legislation of the Republic of Uzbekistan.

In particular, as part of the implementation of the recommendations given to Uzbekistan as a result of the fourth round of monitoring within the framework of the OECD ACN Istanbul AntiCorruption Action Plan, administrative responsibility has been introduced for making decisions in situations of conflict of interest; within the framework of the new version of the Criminal Code being developed, it is envisaged strengthening of liability for corruption crimes, bribery includes such mandatory elements as a bribe of an intangible nature, promise and offer of a bribe, etc. It also provides for the translation of the compositions of administrative offenses, concerning petty theft and bribery of employees in the Criminal Code, the calculation of the statute of limitations for corruption cases increases significantly, an autonomous definition of a foreign official or international organization is

\footnotetext{
1 Закон Республики Узбекистан от 14.01.2021 г. № ЗРУ-666 - Национальная база данных законодательства, 15.01.2021 г., № 03/21/666/0032 — Вступает в силу с 16.04.2021 г. https://lex.uz/docs/5220725

2 Указ Президента Республики Узбекистан № УП-6013 от 29.06.2020 г. «О дополнительных мерах по совершенствованию системы противодействия коррупции в Республике Узбекистан». http://lex.uz/docs/4875786

3 Закон Республики Узбекистан «Об общественном контроле» от 12.04.2018 г. http://lex.uz/docs/3679099?query

4 Закон Республики Узбекистан «О защите потерпевших, свидетелей и иных участников уголовного процесса» 14.01.2019 г. http://lex.uz/docs/4159922?query

5 Постановление Кабинета Министров Республики Узбекистан от 31.12.2020 г. № 829 «Об утверждении Положения о порядке награждения лиц, сообщивших о коррупционных правонарушениях или оказавших иным образом содействие в борьбе с коррупцией». http://lex.uz/docs/5197424
} 
introduced. ${ }^{1}$

Based on the recommendations of the UNODC, UNDP and a number of other international organizations regarding the implementation of the requirements of Article 20 of the UN Convention against Corruption, the new version of the Criminal Code of the Republic of Uzbekistan provides for criminal liability for illegal enrichment. ${ }^{2}$

In order to strengthen the expert potential of state bodies, since 2019, the Academy of the Prosecutor General's Office has been preparing Specialists through conducting training courses for the targeted Master's Program "Combating Corruption", in cooperation with the leading foreign experts from Austria, Georgia, Slovenia, the USA, France, Sweden, the Republic of Korea, Ukraine, etc. with the support of international partners (INGO Regional Dialogue, UNDP, World Bank, UNODC, OECD, UNESCO, OSCE, Council of Europe, EU, Tetra Tech USAID project, JICA, INL, German Foundation for International Legal Cooperation (IRZ), International Anti-Corruption Academy (Vienna), Institute for Legal Initiative in Central and Eastern Europe (CEELI), Berlin Graduate School of Democracy and Good Governance (Germany), Cambridge (Great Britain), Lund (Sweden) universities and others.

Since 2019, the qualifications of employees of the prosecutor's office and other law enforcement agencies are being systematically improved together with international partners (OECD, the StAR Initiative of the World Bank and UNODC, INL, etc.) within the framework of the seminars on "Identification, investigation and proceedings in complex corruption case", "Criminal liability for corruption" etc.

Despite the abovementioned related measures and grand leaps, we believe that in the field of combating corruption there are still problems of both institutional and legal nature. In particular, the activities of state civil servants and law enforcement officers are not sufficiently regulated.

Uniform requirements regarding the procedure for performing service have not been established, a list of restrictions and prohibitions for civil servants has not been determined, the procedure for declaring assets, income and large incomes by civil servants and members of their families has not been introduced. Besides, such elements of crime as abuse of influence, illegal enrichment have not been criminalized, and measures have not been taken to prevent conflicts of interest.

The system of competitive selection for the civil service has not been introduced. The issues of preventing conflicts of interest in the activities of employees are not sufficiently regulated, insufficient attention is paid to the issues of preventing primary manifestations of corruption such as nepotism, cronyism, favoritism, clientism, lobbyism, protectionism.

Uzbekistan is moving away from the methods of criminal-legal response to the facts of corruption to the model of early prevention of corruption offenses, identifying the risks of asocial behavior of officials, minimizing their discretionary powers, maximizing the involvement of civil society institutions, the media and citizens in the fight against corruption offenses, dramatically improving quality public administration, ensuring the transparency of the activities of state bodies, specialization of state bodies in combating corruption and, the maximum involvement of each leader, each state body in the systemic fight against all manifestations of corruption.

The analysis of international standards and best foreign practice in the field of ensuring the inevitability of liability for committing corruption crimes revealed that activities in this area can be optimized by:

improving the activities of investigative bodies to investigate corruption offenses, introduction of the latest ICTs for effective investigation and prosecution of complex financial crimes, improvement of financial investigation of corruption and official crimes, establishing criminal liability for any unlawful gaining, both material and non-material, introduction of contemporary means and methods of disclosing modern forms and methods of committing corruption crimes, strengthening mechanisms to protect whistleblowers, development of international cooperation in this area, active involvement of citizens and civil society institutions in the processes of identifying corruption offenses, etc.

\footnotetext{
${ }^{1}$ Опубликован для всеобщего обсуждения на портале https://regulation.gov.uz/uz/d/29646

${ }^{2} \mathrm{C}$ In order to strengthen the expert potential of state bodies, the Academy of the Prosecutor General's Office from 2019 with the involvement of leading foreign experts from Austria, Georgia, Slovenia, the USA, France, Sweden, the Republic of Korea, Ukraine, etc. with the support of international partners (INGO "Regional Dialogue”, UNDP, World Bank, UNODC, OECD, UNESCO, OSCE, Council of Europe, EU, Tetra Tech USAID project, JICA, INL, German Foundation for International Legal Cooperation (IRZ), International Anti-Corruption Academy (Vienna), Institute for Legal Initiative in Central and Eastern Europe (CEELI), Berlin Graduate School of Democracy and Good Governance (Germany), Cambridge (Great Britain), Lund (Sweden) universities and others. Specialists are being trained in the targeted master's program “Combating Corruption”.м. там же
} 


\section{KORRUPSIYA JAMIYAT RIVOJINING ZAVOLI}

\section{Raxmonqulov Shoxrux Akram o'g'li}

Mustaqillikning ilk kunlaridan boshlab mamlakatimizda demokratik huquqiy davlat va kuchli fuqarolik jamiyati qurishning umumiy strategiyasini amalga oshirish doirasida qonun ustuvorligini ta'minlash, fuqarolarning huquq va erkinliklarini himoya qilish, sud-huquq tizimini isloh qilish yuzasidan qator chora-tadbirlar izchil amalga oshirib kelinmoqda.

Tarixan qisqa davr ichida mamlakatda qonuniylik va huquq-tartibotni ta'minlashning institutsional va huquqiy asoslari shakllantirildi, korrupsiyaga qarshi kurashishning samarali tizimi yaratildi.

Mazkur yo"nalishdagi islohotlarni amalga oshirish davomida milliy qonunlarga xalqaro huquqning umume'tirof etilgan normalarini singdirish masalasiga alohida e'tibor berildi va bu munosabat 2008 yilda qabul qilingan «Birlashgan Millatlar Tashkilotining korrupsiyaga qarshi konvensiyasiga (NyuYork, 2003 yil 31 oktyabr) O‘zbekiston Respublikasining qo“shilishi to'g'risida»gi Qonunda o“z aksini topdi.

2010 yilda O`zbekiston Iqtisodiy hamkorlik va rivojlanish tashkiloti Korrupsiyaga qarshi kurashish tarmog'ining Istambul harakat dasturiga qo'shildi.

So'nggi yillarda korrupsiyaga qarshi kurashishning huquqiy mexanizmlarini takomillashtirishga qaratilgan bir qator muhim normativ-huquqiy hujjatlar, jumladan Byudjet va Bojxona kodekslari (yangi tahrirda), «Huquqbuzarliklar profilaktikasi to'g'risida»gi, «Ijtimoiy sheriklik to'g'risida»gi, «Davlat hokimiyati va boshqaruvi organlari faoliyatining ochiqligi to 'g'risida»gi, «Tezkor-qidiruv faoliyati to' $\mathrm{g}^{6}$ risida»gi, «Elektron hukumat to' $\mathrm{g}^{6}$ risida»gi, "Ichki ishlar organlari to' $\mathrm{g}^{6}$ 'risida»gi qonunlar qabul qilindi.

Iqtisodiyotni erkinlashtirish, ishchanlik muhitini yaxshilash, kichik biznes va xususiy tadbirkorlik uchun qulay sharoitlar yaratish, ma'muriy to'siqlarni bartaraf etish hamda litsenziyalash va ruxsat berish tartib-taomillarini soddalashtirish, davlat xaridlari mexanizmlarini takomillashtirish, davlat xizmatchilarining odob-axloq qoidalarini tasdiqlashga doir bir qator chora-tadbirlar amalga oshirildi.

Korrupsiyaga qarshi kurashishning huquqiy asoslarini yanada takomillashtirish maqsadida O‘zbekiston Prezidenti Shavkat Mirziyoyev tomonidan 2017-yil 3-yanvar kuni "Korrupsiyaga qarshi kurash to 'g'risida"gi qonun imzolandi. E'lon qilingan kundan boshlab kuchga kiruvchi qonun 4-yanvar kuni "Xalq so "zi" va "Narodnoye slovo" gazetalarida chop etildi.

Qonundan ko"zlangan maqsad korrupsiyaga qarsha kurash sohasidagi munosabatlarni tartibga solishdan iborat. Hujjatda "korrupsiya", "korrupsion huquqbuzarlik" va "manfaatlar mojarosi" kabi tushunchalarga izoh berilgan.

Hujjatda korrupsiyaga qarshi kurashning asosiy tamoyillari sifatida qonuniylik; fuqarolarning huquqlari, erkinliklari va qonuniy manfaatlari ustuvorligi; ochiqlik, shaffoflik va tizimlilik; davlat va fuqarolik jamiyatining o'zaro hamkorligi; korrupsiyadan ogohlantirish va javobgarlikning muqarrarligi bo'yicha choralar ustuvorligi keltirib o'tilgan.

Qonun korrupsiyaga qarshi kurash sohasida davlat siyosatining asosiy yo"nalishlarini keltirib o'tadi:

- aholining huquqiy savodxonligi va huquqiy madaniyatini oshirish, jamiyatda korrupsiyaga nisbatan toqatsizlikni shakllantirish;

- davlat va jamiyat hayotining barcha sohalarida korrupsiyadan ogohlantirish bo'yicha choralarni amalga oshirish;

- $\quad$ korrupsion huquqbuzarliklarni o'z vaqtida aniqlash, ular oqibatlari, sabablari va keltirib chiqargan sharoitlarni bartaraf etish hamda korrupsion huquqbuzarliklar sodir etilgani uchun muqarrar jazolash tamoyilini tadbiq etish.

Hujjatda davlat boshqaruvi sohasida korrupsiyadan ogohlantirish bo'yicha choralarni keltirib o'tadi. Jumladan, davlat organlari faoliyatining ochiqligi va hisobdorligini ta'minlash, parlament va jamoatchilik nazorati, mansabdor shaxslar faoliyati sifatini baholash hamda ishga qabul qilish va mansab pillapoyalaridan ko 'tarilishda ochiqlik va xolislik tamoyili asosida tanlovli saralashlarni olib borish tizimlarini joriy etish belgilangan. Davlat organlari xodimlarining huquqiy maqomi aniqlanib, ularning ijtimoiy himoyasi, moddiy ta'minoti, har tomonlama rag'batlantirish choralari ko'riladi.

Ijtimoiy-iqtisodiy taraqqiyot va tadbirkorlik sohalarida korrupsiyadan ogohlantirish bo'yicha choralar qatoridan esa ma'muriy va byurokratik to'siqlarni bartaraf etish, ro'yxatga olish, ruxsat berish va litsenziyalash jarayonlarini soddalashtirish va tezkorligini oshirish, davlat organlarining 
nazorat-tekshiruv vakolatlarini optimallashtirish hamda ular va tadbirkorlik sub'ektlari o'rtasida o'zaro munosabatlarning masofaviy shakllarini joriy etish belgilangan.

Ma'muriy jarayonlar sohasida korrupsiyadan ogohlantirish choralari ro'yxatiga ularning batafsil reglamentini belgilash, ushbu jarayonlarni soddalashtirish va byurokratik rasmiyatchiliklarga yo'1 qo“ymaslik kiritilgan.

Qonunda davlat organi xodimi biror bir shaxs tomonidan uni korrupsion huquqbuzarlikni sodir etishga da'vat qilish holati, shuningdek, boshqa ishchilar tomonidan shu kabi holatlarning amalga oshirilishi bo'yicha unga oshkor bo'lgan ma'lumotlarni o'z rahbari yoki huquqni muhofaza qilish organlariga murojaat etishi belgilangan. Mazkur majburiyatlarning bajarilmasligi qonunchilikka muvofiq tegishli ravishda jazoga tortilishiga olib keladi.

Korrupsion jinoyat to ' $\mathrm{g}$ 'risida oshkor qilgan shaxs davlat himoyasi ostiga olinadi. Biroq mazkur qoida yolg'on ma'lumotlarni taqdim etganlarga nisbatan amal qilinmaydi.

Qonunning alohida moddasi har kim tashkilotlar va davlat organlari faoliyati, mazkur shaxslar yoki shaxslar guruhiga taalluqli qabul qilinayotgan aktlar to'g'risida ma'lumot olish huquqiga ega ekanligini ko'zda tutadi. Davlat organlari, fuqarolarning o'zini o'zi boshqarish organlari va tashkilotlar OAVga korrupsiya bilan bog'liq hodisalar, dalillari, voqealar va jarayonlan to' $\mathrm{g}^{\text {' }}$ risida jamoatchilik uchun qiziqarli bo'Igan ma'lumotlarni taqdim etadi. 


\title{
КИБЕРЖИНОЯТЛАРНИ ТЕРГОВ КИЛИШДА ЭКСПЕРТ КЎРСАТУВЛАРИНИ ТЕКШИРИШ ВА БАХОЛАШ
}

\author{
Б.Х. Хамидов \\ Тошкент давлат юридик университети \\ Криминалистика ва суд экспертизаси \\ кафедраси катта ўқитувчиси \\ E-mail: Bahtiyor1984bsj@mail.ru
}

Ушбу мақолада Ўзбекистон шароитида кибержиноятларни тергов қилишда эксперт кўрсатувларини текшириш ва рақамли далилларни бахолашга доир умумназарий масалалари тахлил этилган. Мақола кибержиноятларга қарши кураш фаолиятининг услубий асосларини такомиллаштиришга қаратилган назариётчи олимлар, амалиётчи ходимлар қарашлари хамда илмий мақолалар тахлили асосида тайёрланган. Унда сохада юзага келаётган муаммолар тизимли, хуқуқий, илмий-методик жихатдан ўрганилган ва бу юзасидан муаллифлик хулосалари берилган.

Калит сўзлар: давлат дастури, эксперт, мутахассис, кибержиноятлар, рақамли далил, рақамли далиллар мақбуллиги.

Сўнги йилларда кибержиноятларни тергов қилишга оид қонунчилик базасини такомиллаштириш бўйича хукуматимиз томонидан қатор ишлар амалга оширилмоқда. Хусусан, Ўзбекистон Республикаси Президентининг 2021 йил 3 февралдаги ПФ-6155-сон Фармони билан тасдиқланган Давлат дастурига мувофиқ Интернет тармоғида, шу жумладан ижтимоий тармоқларда содир этилаётган хуқуқбузарлик ва жиноятларнинг олдини олиш чораларини такомиллаштириш белгиланган ${ }^{1}$.

Рақамли далиллар бўйича эксперт кўрсатувларини текшириш ва бахолаш тартибига оид қоидалар Ўзбекистон Республикаси Жиноят-процессуал қонунчилигида мавжуд эмас. Шу боис, экспертиза амалиётида муайян процессуал ва услубий хатоликлар юзага келмокда.

Қоида тариқасида, эксперт рақамли далилларни тўплаш, текшириш ва бахолаш натижалари бўйича илмий асосланган хулоса беради. Суд мухокамасида ўтказилган тадқиқотнинг хусусиятлари, методлари хамда воситалари бўйича илмий асосланган тушунтиришлар беради. Бунда эксперт (мутахассис) далилларни тўплаш, тахлил қилиш ва бахолаш жараёнида ўзининг барча хатти-харакатларини босқичма-босқич хужжатлаштириши, далилларни олиш ва текшириш усуллари хамда воситалари кўрсатилиши, бахолаш мезонларини ва қийматлаш масалалари батафсил изохлаб берилади. Шу билан бирга, эксперт (мутахассис) натижалар (жараён)ни амалда қайта бажариб кўрсатиб бериши шарт.

Экспертиза тадқиқоти натижалари судья, прокурор, адвокат томонидан текширилганда бир хил қийматни бериши шарт. Шу орқали далилларнинг мақбуллиги таъминланади. Компьютер ахбороти билан боғлиқ жиноятларни тергов қилишда рақамли далилларни эксперт (мутахассис) кўрсатувларини текширмасдан бахолаш хатоликларга олиб келади.

Рақамли далиллар бўйича эксперт (мутахассис) кўрсатувлари содда ва тушунарли шаклда бўлиши мақсадга мувофиқ. Тергов ёки экспертиза натижалари судда иштирок этаётган барча томонлар учун объектив шаклда тавсифланиши зарур. Бунда махсус терговчи ёки мутахассисларларнинг иштироки исботлаш жараёнини муваффақиятини таъминлайди².

Эксперт (мутахассис) тегишли электрон қурилмада мавжуд бўлган рақамли далилларни тўплаш, текшириш, хужжатлаштириш, сақлаш ва тахлил қилиш учун жавобгар хисобланади. Шунинг учун хам ушбу шахс судда далилларнинг қандай топилганлиги, яратилганлиги ва олинганлиги хамда далилларни олиш жараёнидан қасддан ёки эхтиётсизлик натижасида рўй бериши мумкин бўлган ўзгаришлар тўғрисида гувохлик беради ва ўзи амалга оширган жараёнларни такрорлаб, кўрсатиб беради хамда натижанинг ишончли эканлигини исботлайди.

1 2017-2021 йилларда Ўзбекистон Республикасини ривожлантиришнинг бешта устувор йўналиши бўйича Харакатлар стратегиясини “Ёшларни қўллаб-кувватлаш ва ахоли саломатлигини мустахкамлаш йили”да амалга оширишга оид давлат дастури 36-банди.

${ }_{2}$ Marie-Helen Maras. "Computer Forensics: Cybercriminals, Laws, and Evidence”. 2nd Edition. USA. Jones \& Bartlett Learning, LLC. 2015. - 564 p. 
Мария-Хелен Мараснинг таъкидлашича рақамли криминалистик амалиётда терговчилар фақатгина далилларни топиш, тиклаш ёки олиш билан чекланиб қолмасдан, тергов давомида қўлга киритилган маълумотларни судга тақдим этиши ва асослаб бериши лозим ${ }^{1}$. Хақиқатан хам бу ўринда М. Мараснинг фикри ўринли. Ушбу жараён бир неча ижобий жихатларни яъни, далилларни мақбуллиги, ишончлиги, яхлитлигини хамда бошқа коррупциявий элементлардан мухофаза қилинишини таъминлайди.

Ривожланган давлатлар қонунчилигида хам эксперт кўрсатувларини текшириш ва далилларни бахолаш (АҚШ ${ }^{2}$, Буюк Британия ${ }^{3}$, Австралия ${ }^{4}$, Норвегия 5 , Шведция ${ }^{6}$ ва х.к.)да хам қатъий тартиблар жорий этилган.

Далилларни бахолашда рақамли далилнинг барча хусусиятлари хисобга олинади. Далиллар уларнинг алоқадорлиги, мақбуллиги, ишончлилиги ва етарлилиги жихатидан бахоланади. Мазкур хусусиятлар уларни бахолашда мухим ахамиятга эга бўлиб, уларнинг бири талабга жавоб бермаган холларда далил айблаш ва хукм қилиш учун асос бўлиб хизмат қила олмайди. Айрим олимлар далилларни бахолаш мазмунига уларнинг иш бўйича объектив хақиқатга эришишга таъсир этувчи барча хусусиятларини белгилаш киради그 деб хисоблашган.

Далилни бахолаш мезонлари бўйича қатор фикр ва мулохазалар мавжуд. Айрим олимлар далилларни бахолашда унинг ишончлилиги асосий мезон сифатида қабул қилишган бўлса, бошқалари далил кучи ва ахамиятини, учинчи гурух олимлар эса далилнинг мақбуллиги, ишончлилиги, алоқадорлиги ва ахамиятини кўзда тутадилар.

Рақамли далилларни бахолашда уларнинг алоқадорлиги, мақбуллиги, ишончлилиги ва етарлилиги билан бирга уларнинг яхлитлиги хам текширилади. Ривожланган мамлакатларда, жумладан АҚШ ${ }^{8}$ да рақамли далилларни бахолашда текширилиши лозим бўлган дастлабки талаблар белгиланган. Бу борада, Вассил Роуссев томонидан ишлаб чиқилган мезонлар хақиқатга анча яқин. У Дауберт стандартига мос равишда рақамли далилларни судга тақдим этиш ёки улар юзасидан кўрсатувларни бахолашнинг куйидаги асосий мезонларини таклиф этган 9

1. Тергов ва экспертиза давомида қўлланилган методлар назарий асосланган бўлиши;

2. Криминалистик амалиётда қўлланилган услублар хуқуқни мухофаза қилувчи органларнинг журналлари, рўзнома ёки интернет сайтларида чоп этилиши кераклиги;

3. Тадқиқот усулининг хато қилиш даражасини қандай эканлиги;

4. Амалиётда қўлланиладиган методлар бирор илмий жамиятда қабул қилиниши кераклиги.

Ушбу стандартлар рақамли далилларининг тўғрилиги ва эксперт кўрсатувларини хаққонийлигини текширишда кенг имконият беради. ${ }^{10}$ Бироқ, улар рақамли далилларни тўплаш жараёнларини хам қамраб олади. Шу боис, ушбу мезонлар рақамли далилларни бахолаш мезонларини тўлиқ акс эттирмайди.

Суд мухокамасида эксперт ёки мутахассиснинг рақамли далиллар юзасидан хисоботи тингланади. Агар лозим бўлса, эксперт ёки мутахассисдан тушунтиришлар ва изохлар талаб қилиниши мумкин. Агар суд ёки томонлардан бири эксперт ёки мутахассисдан бажарилган харакатларни такрорлашни талаб қилса, улар буни амалга оширадилар ва томонлардан бири

\footnotetext{
1 Marie-Helen Maras. "Computer Forensics: Cybercriminals, Laws, and Evidence”. 2nd Edition. USA. Jones \& Bartlett Learning, LLC. 2015. - 564 p.

2 Albert J. Marcella, Jr. Doug Menendez. "Cyber Forensics: A Field Manual for Collecting, Examining, and Preserving Evidence of Computer Crimes”. 2nd Edition. New York, USA. Taylor \& Francis Group, LLC. 2008. - 498 p.

3 Anthony T.S. Ho and Shujun Li. "Handbook of digital forensics of multimedia data and devices". Guildford, UK. John Wiley \& Sons, Ltd., 2015. - 688 p.

${ }^{4}$ Richard Boddington. "Practical Digital Forensics". Birmingham, UK. Packt Publishing Ltd., 2016. - 372 p.

5 Andre Arnes. "Digital Forensics". Hoboken, Norway. John Wiley \& Sons Ltd, 2018. - 366 p.

6 Joakim Kävrestad. "Fundamentals of Digital Forensics". Skövde, Sweden. Springer International Publishing, 2018. $-227 \mathrm{p}$.

7 Фаткуллин Ф.Н. Общие проблему процессуального доказўвания. Казань, 1973. С.150

${ }^{8}$ Andre Arnes. Digital Forensics. John Wiley \& Sons, Inc., 111 River Street, Hoboken, USA 2018 - pp. 68-69

9 Vassil Roussev. Digital Forensic Science: Issues, Methods, and Challenges. - Morgan \& Claypool Publishers series. University of Texas, San Antonio. 2016. - p. 10

${ }^{10}$ Goodstein, D. Reference Manual on Scientific Evidence, 3rd ed., National Academies Press, 2011, ch. The Admissibility of Expert Testimony, pp. 37-54.
} 
ёки суд хам ушбу жараённи такрорлаб кўриши мумкин. Жараённи такрорлаш натижасида бир хил натижага эришилса, демак олинган далиллар мақбул ва ишончли хисобланади. Олинган фактик маълумотлар ижтимоий хавфли қилмишнинг бир ёки бир неча қисмини боғлашга имкон берса, демак далиллар алоқадор хисобланади.

Тергов ва экспертиза жараёнида олинган маълумотларнинг яхлитлигини текшириш рақамли далилларни тўплаш, сақлаш, текшириш босқичларини қамраб олади. Бунда рақамли курилма ва ахборот ташувчиларнинг тадқиқот жараёндан олдинги ва кейинги хеш қийматлари хамда барча маълумотларнинг хеш ва назорат қийматларини текширилади. Агар қийматлар бир хил бўлса, демак ушбу далиллар яхлит ва ўзгармаган хисобланади. Агар техник жихатдан далилларнинг қийматлари ўзгарган бўлса, эксперт ёки мутахассис буни тушунтириши ва асосли сабаб келтириши лозим. Акс холда, далиллар номақбул деб хисобланади.

Техник талаблар бўйича, суд른

рақамли далилларни олиш, сақлаш ва тахлил қилиш учун фойдаланилган процедура ва воситаларини;

рақамли суд экспертизаси лабораторияси (кейинги ўринларда лаборатория деб юритилади) экспертлари берган хисоботлари ва хулосаларини танқидий бахолайди ${ }^{2}$.

2017 йилда, Антви-Боасиако (Antwi-Boasiako) ва Вентерлар (Venter) томонидан рақамли далилларни мақбуллигининг техник ва хуқуқий талаблари бўйича "Рақамли далиллар мақбуллигини бахолашнинг ягона модели"ни (Harmonized Model for Digital Evidence Admissibility Assessment (HM -DEAA )) ишлаб чиқилган. Мазкур моделда рақамли далилларни бахолашнинг қуйидаги уч босқичи кўрсатилган.

рақамли далилларнинг мақбуллигини бахолаш;

рақамли далиллар кўриб чиқиш;

рақамли далилларнинг мақбуллиги бўйича қарор қабул қилиш.

а) Рақамли далилларнинг мақбуллигини бахолаш

Мазкур босқичда рақамли далилларни олишда процессуал қонунчилик ва халқаро стандларга риоя этилганлиги хамда уларнинг ахамияти криминалистик жихатдан бахоланади.

Процессуал қонунчиликда белгиланган талаблар рақамли қурилмани кўздан кечириш, тинтув ва олиб қўйиш, санкция олиш ва х.к. масалаларни қамраб олади. Стандартларга риоя этиш дегада рақамли далилларни олиш, сақлаш ва текшириш бўйича умумэътироф этилган қоидаларни хисобга олингани текширилади.

б) Рақамли далиллар кўриб чиқиш

Ушбу босқичда рақамли далилларнинг яхлитлиги, яъни уларни олиш, сақлаш ва тахлил қилишда экспертиза процедуралари ва воситаларига риоя қилинганлиги бахоланади. Хорижий давлатлар (масалан АҚШ, Англия, Жунубий Африка ва б.)да мазкур босқичда экспертнинг малакаси ва ушбу экспертиза ўтказилган муассасалар хам судлар томонидан бахоланади ${ }^{3}$.

Эксперт хулосаларини судда асосланиши.

Экспертлар томонидан рақамли курилма, Интернет платформалар ва бошқа манбалар қандай ишлаши, рақамли далиллар қандай олингани, сақлангани ва тахлил этилгани, ўтказилган тахлил натижаларини шархланиши (шархдаги аниқлик), иш учун ахамиятга эга бўлган хар қандай ўзгаришлар (нима учун ўзгартирилгани) асослаб берилиши зарур.

Бундан ташқари, лаборатория тадқиқотида амал қилинган стандартлар ва протоколлар хам ўрганилиши лозим. Бундан мақсад лабораторияда рақамли далилларни тахлил этиш ва натижаларни ишончлилигини таъминлаш учун ишончли методлар, рақамли қурилмалар ва дастурий воситалар, компетентли ходимлар хамда асосланган хулосалар бериш имконияти мавжудлигини аниқлашдир.

с) Рақамли далилларнинг мақбуллиги бўйича қарор қабул қилиш.

Ушбу босқичда рақамли далилларнинг хақиқийлиги, яхлитлиги ва ишончлилиги иккинчи босқич натижаларига асосан бахоланади. Масалан, рақамли далилларни олиш методлари ва воситалари ишончлилиги нуқтаи назаридан бахоланади хамда экспертларнинг кўрсатувлари солиштирилади ${ }^{4}$.

\footnotetext{
1 Миллий қонунчиликка кўра терговчи, прокурор ва суд назарда тутилади.

${ }^{2}$ https://www.unodc.org/e4j/ru/cybercrime/module-6/key-issues/digital-evidence-admissibility.html

3 SWGDE Overview of the Accreditation Process for Digital and Multimedia Forensic Labs, 2017

${ }^{4}$ Antwi-Boasiako and Venter, 2017; US National Institute of Justice, 2004a
} 
Рақамли далиллар ишнинг хақиқий холатини аниқлаш имконини берган тақдирда хамда барча экспертиза жараёнларида ўзгаришсиз қолсагина мақбул деб топилади. Шу билан бирга, экспертиза натижалари хақиқий, ишончли ва эксперт бахолашидан ўтиши шарт ${ }^{1}$. Натижалар хақиқий деб топилиши учун улар холис тарзда талқин қилиниши, натижалардаги хатолар ва ноаниқликлар, шунингдек натижаларни талқин қилишдаги чекловлар хақидаги маълумотлар ошкор қилиниши керак.

Хулоса қилиб айтганда, эксперт кўрсатувларини текшириш ва рақамли далилларни бахолашда терговчи, прокурор ва суд:

эксперт хулосасининг процессуал қонун талабларига риоя қилинган холда расмийлаштирилганлиги;

эксперт кўрсатувлари ахлоқ қоидалари доирасида амалга оширилгани;

рақамли далилларни тўплаш, сақлаш ва текширишнинг илмий асосланган методлари ва воситаларига амал қилингани;

рақамли далилларнинг мақбуллиги таъминлангани;

эксперт кўрсатувларини қайта такрорлаш орқали бир хил қийматга эришиш имкониятининг мавжудлигини хисобга олишлари шарт.

\footnotetext{
${ }^{1}$ Brezinski and Killalea, 2002; US National Institute of Justice, 2004a; European Network of Forensic Science Institute, 2015
} 


\title{
ВЛИЯНИЕ ДОГОВОРНЫХ ХАРАКТЕРИСТИК НА ЭФФЕКТИВНОСТЬ ГОСУДАРСТВЕННО-ЧАСТНОГО ПАРТНЕРСТВА
}

Каюмов Бахтиёр Эркинжонович

Начальник кафедры Академии Генеральной прокуратуры Республики Узбекистан, самостоятельный соискатель Ташкентского государственного юридического университета

\begin{abstract}
Аннотация. В статье анализируются четыре важные особенности договора государственно-частного партнерства, чтобы понять их влияние на результативность: 1. возможность, предусмотренная договором, наложения санкций, 2. сложность договора; 3. гибкость и 4. возможность повторных переговоров. Автор приходит к выводу, что единственная особенность, которая имеет какое-либо существенное влияние на эффективность - это возможность введения санкций.
\end{abstract}

Ключевые слова: государственно-частное партнерство, санкции, договор, гибкость, переговоры, эффективность, инфраструктура.

Развитие государственно-частного партнерства (ГЧП) стало общей стратегией управления во многих странах для улучшения предоставления государственных услуг и для крупных проектов государственной инфраструктуры. ГЧП вовлекает частный сектор, который, как предполагается, лучше и эффективнее управляет строительством, финансированием, обслуживанием и эксплуатацией инфраструктуры (например, за счет использования новых технологий, новых идей или новых способов ведения дел). Договоры ГЧП призваны стимулировать партнеров из частного сектора использовать свои навыки для создания более качественных государственных услуг на основе инфраструктуры. В академической литературе по контрактам на проектирование, строительство, финансирование, техническое обслуживание и эксплуатацию (design, build, finance, maintain and operate - DBFMO) в рамках ГЧП подчеркивается, что договоры имеют решающее значение для успеха [1].

Продолжительность срока действия договора и возможности наложения санкций, если услуги или продукты не соответствуют условиям договора, как правило, считаются особенно важными. Долгосрочные договоры позволяют частным партнерам использовать более инновационные методы осуществления условий договора. Санкции необходимы, чтобы предвидеть оппортунистическое поведение партнеров по договору и реагировать на него, а также для повышения их эффективности в ходе выполнения контракта.

С точки зрения заключения договоров [2] подчеркивается гибкость договора и пространство, которое он оставляет для переговоров. Еще одна важная характеристика - сложность договора. Составление и реализация сложных договоров требует большего внимания и более высоких транзакционных издержек и, следовательно, может повлиять на эффективность партнерских отношений [3].

Аргументы в пользу ГЧП обычно связаны с условиями договоров. Их относительно жесткий характер с четкими положениями о мониторинге и санкциях рассматривается как их сильная сторона [4]. Длительный договорный период позволяет частным лицам распределять риски и вводить новшества. Оба эти допущения вдохновлены неоэкономической институциональной теорией и новыми идеями государственного управления (на которые сильно влияют экономические теории). Другие дисциплины подчеркивают реляционный характер ГЧП и, таким образом, возможности для пересмотра условий и построения доверия [5].

В литературе по договорам DBFMO продолжительность договора упоминается как важная, потому что частным партнерам нужно время, чтобы вернуть свои первоначальные инвестиции [6]. Длительные договоры также могут способствовать общему качеству продукта или услуги. Поскольку эти проекты объединяют несколько этапов, подрядчики могут и заинтересованы инвестировать в более качественные материалы на этапе строительства, чтобы в дальнейшем иметь меньшие затраты на техническое обслуживание. Таким образом, длительные периоды договоров могут быть связаны с хорошей общей производительностью: меньшими затратами (рентабельностью), более качественными услугами и продуктами, а также более инновационными решениями и продуктами.

Еще одна особенность договоров ГЧП, отмеченная в литературе, - это использование 
санкций [7]. Учитывая возможность непредвиденного развития событий в будущем, правительству необходимо иметь инструменты, позволяющие влиять на поведение и результаты деятельности частного партнера в период действия договора. Для этого в договорах может быть предусмотрена возможность применения положительных и отрицательных санкций во время выполнения условий договора. Это означает, что в договоре должны быть указаны показатели эффективности и система мониторинга. Конкретные инвестиции - это вложения в виды деятельности или продукты, которые не могут быть легко использованы в других проектах. Это делает партнера-инвестора зависимым от другого партнера, что может привести к оппортунистическому поведению, например, сокращению пути или экономии на качестве. Поэтому очень важно, чтобы подрядчик (принципал) имел возможность контролировать и налагать санкции на подрядчика (агента), если последний не может предоставить обещанный продукт и в обещанном качестве. Таким образом, предполагается, что угроза санкций способствует эффективности ГЧП.

Роль транзакционных издержек и тип отношений являются важными вопросами, которые необходимо учитывать при выборе типа договора. Когда транзакции проводятся нечасто и инвестиции осуществляются конкретными партнерами, возникает необходимость либо в сложных договорах, в которых указываются все возможные варианты, либо в дополнительных механизмах управления (например, больше инвестиций в управление договорами).

Согласно O.E. Williamson [3] всякий раз, когда инвестиции являются идиосинкразическими в нетривиальной степени, увеличение степени неопределенности делает все более настоятельной необходимость того, чтобы стороны разработали механизм для «решения проблем», поскольку договорные пробелы будут больше, а возможности для последовательной адаптации увеличатся в количестве и важности по мере того, как степень неопределенности увеличивается. В качестве решения он предложил следующее - существуют две возможности. Можно было бы пожертвовать ценными конструктивными особенностями в пользу более стандартизированных товаров или услуг. Тогда будет применяться управление рынком. Вовторых, сохранить структуру, но окружить транзакцию продуманным аппаратом управления, способствуя тем самым более эффективному адаптивному последовательному принятию решений.

Конечно, выбор его первого варианта означал бы отказ от потенциала добавленной стоимости (на самом деле это означает выбор другого типа решения / продукта). Второй вариант влечет за собой дополнительные транзакционные издержки.

Сложные проекты, реализуемые в рамках ГЧП, требуют определенных транзакций. Следовательно, для управления этими проектами необходимы более сложные договоры или, в качестве альтернативы, различные формы управления (например, более реляционныедоговоры). Преимущество сложного договора состоит в том, что он включает в себя множество разных условий, но к его недостаткам относится то, что его составление дорого (потому что требуется много информации и переговоров), он менее гибкий и приведет к высоким транзакционным издержкам на мониторинг и реализацию. Следовательно, можно предположить, что чем сложнее договор, тем меньше его общая эффективность. Взаимосвязь между сложностью и инновациями труднее понять, поскольку в литературе мало четких идей.

Теория неоинституционализма утверждает, что разные ситуации могут требовать разных форм договоров. Другие авторы теории договоров подчеркивают, что реляционные договоры более подходят для сложных партнерств, где требуются инновации и специфические транзакции, чем для более классических договоров, которые имеют фиксированные показатели эффективности [2]. Реляционные договоры относятся к договорам с глобальными соглашениями, которые предполагают, что партнеры будут действовать в соответствии с духом соглашения в конкретных ситуациях, которые не могут быть указаны заранее.

Некоторые авторы подчеркивают, что, особенно когда отношения становятся более сложными, очень важно, чтобы договоры были гибкими. «Гибкость» означает, например, что технические характеристики могут быть изменены, а условия договора пересмотрены [8], чтобы учесть неизвестные изменения условий во время выполнения условий договора. Жесткий договор, не допускающий пересмотра условий, может привести к неоптимальным результатам или даже к краху партнерства. Кроме того, жесткий договор может не позволять сторонам реализовывать новые идеи и решения.

Таким образом, мы пришли к выводу, что более длительный срок договора положительно 
влияет на эффективность и на инновации в ГЧП, договор с возможностью применения санкций положительно влияет на результативность ГЧП, сложность договора отрицательно влияет на общую эффективность проекта ГЧП, договоры, которые являются более гибкими и дают возможность для переговоров, положительно влияют на общую эффективность проекта ГЧП, и договоры, которые являются более гибкими и позволяют вести переговоры, положительно относятся к инновациям в ГЧП.

\section{Список использованной литературы:}

1. Koppenjan, J.F.M. (2015), Public-private partnerships for green infrastructures. Tensions and challenges. Current Opinion in Environmental Sustainability, 12, pp. 30-34. doi: 10.1016/j. cosust.2014.08.010.

2. Deakin, S. and Michie, J. (Eds), (1997), Contract, Co-operation, and Competition: Studies in Economics, Management and Law (Oxford University Press).

3. Williamson, O.E. (1996), The Mechanisms of Governance (Oxford University Press).

4. Weihe, G. (2009), Public-Private Partnerships: Meaning and Practice (Copenhagen Business School).

5. Brown, T.L., Potoski, M. and Van Slyke, D.M. (2007), Trust and contract completeness in the public sector. Local Government Studies, 33, 4, pp. 607-623. doi: 10.1080/03003930701417650.

6. Hodge, G., Greve, C. and Boardman, A. (2010), International Handbook on Public-Private Partnerships (Edward Elgar).

7. Van de Velde, D., Veeneman, W. and Schipholt, L.L. (2008) Competitive tendering in The Netherlands: central planning vs. functional specifications. Transportation Research Part A: Policy and Practice, 42, 9, pp. 1152-1162.

8. Verweij, S. (2015), Achieving satisfaction when implementing PPP transportation infrastructure projects. International Journal of Project Management, 33, 1, pp. 189-200. doi: 10.1016/j. ijproman.2014.05.004. 


\title{
ЁШЛАР ТАРБИЯСИДА ДАВЛАТ ВА ФУҚАРОЛИК ЖАМИЯТИ ИНСТИТУТЛАРИНИНГ ХАМКОРЛИГИ
}

\author{
Н.Т.Тургунова \\ ИИВ Академияси ўқитувчиси,
}

\begin{abstract}
Аннотация: Ушбу мақола ёшларга оид давлат сиёсатини амалга оширишда давлат ва фуқаролик жамияти институтларининг ўзаро хамкорлиги хамда унинг йўналишлари масаласи ёритилган.
\end{abstract}

Калит сўзлар: Давлат, фуқаролик жамияти институтлари, жамоатчилик назорати, ижтимоий шерикчилик.

Аннотация: В статье рассматривается взаимодействие государственных институтов и институтов гражданского общества при реализации государственной молодежной политики и ее направлений.

Ключевые слова: государство, институты гражданского общества, общественный контроль, социальное партнерство.

Resume: The article examines the interaction of state institutions and civil society institutions in the implementation of state youth policy and its directions.

Key words: state, civil society institutions, public control, social partnership.

Бугунги кунда Ўзбекистонда амалга оширилаётган туб ўзгаришлар ва ислохотларнинг асосини фуқаролик жамияти институтларини жамиятнинг илғор кучига айлантириш ташкил қилмокда. Ўзбекистон Президенти Ш.Мирзиёев ўзининг 2020 йил 29 декабрдаги Олий Мажлисга Мурожаатномасида бу тўғрида шундай деган эди: хุар құандай жамият тараққиётида унинг келажагини таъминлайдиган ёш авлоднинг совлом ва баркамол бўлиб вояга етиши хал құлувчи уррин тутади. Шу сабабли биз ислохқотларимиз кўлами ва самарасини янада оширишда хқар томонлама етук, замонавий билим ва хунарларни пухта эгаллаган, азму шижоатли, ташаббускор ёшларимизга таянамиз ${ }^{2}$.

Ёшлар ташкилотларининг ривожи куипинча марказлашган ва тармоқ шаклга эга бўлиб, амалда бу уларнинг фаолият самарадорлигини пасайтиради. Айни вақтда, бундай шакл барқұарор хиисобланса-да, ёшлар қ̧атъий чегараланган ва доимий назорат функиияларига эга тузилмаларда узз салохуиятини тулла амалга ошира олмайдилар. Бу шунингдек, ёшларнинг инноваџион салохииятга эга эканлиги ва фикр эркинлигига интилишлари омили билан хуам боглиқ. Айни вақтда, бу мураккаб, лекин мухуим хуодиса бўлиб, жамиятдаги демократлашув жараёнларида ёшлар ролини оширади. Мутахассис М.Қориева фикрича, демократик жамиятнинг асосий хусусиятларини қ̧арор топтиришда ёшлар фаоллик куррсатиши ижобий хзолдир ${ }^{2}$.

Бу борада хориж тажрибасини куирадиган бўлсак, Европа давлатларининг аксариятида 40 фоиздан ошиқ ёшлар турли жамоат ташкилотлари, уюшмалар ва клубларда фаол иштирок этади. Россияда бу куррсаткич 25 фоизни ташкил қулади. Ахуамиятлиси, бунда уларни бирлаштириб турадиган асосий жихат сифатида қ̧изиқиши ва манфаатларнинг уйвунлиги эътироф этилади.

Тахлиллар шуни кўрсатадики, Ўзбекистонда ёшларга оид давлат сиёсатини самарали амалга ошириш масаласи мамлакатни хар томонлама ривожлантириш, жамиятдаги ижтимоий муносабатларни такомиллаштириш хамда барқарорликни таъминлаш вазифалари билан уйғунлашган. Хусусан, бу ёшлар муаммоларини ўрганиш билан узвий боғлиқ бўлиб, куйидаги қатор жихатларни ўз ичига олади: ёшларни ижтимоий реаллик сифатида қабул қилиш, ёш билан боғлиқ психологик хусусиятларни доимий уррганиб бориш, ёшларни ижтимоийлаштириш йўналиши илғор замонавий моделларни қўллаш, ёшларнинг иқтисодиётдаги ўрни ва улушини ошириш, ёшларнинг хаётий қадриятларини макон ва замон тараққиётидан келиб чиқиб

\footnotetext{
1 Ўзбекистон Президенти Ш.Мирзиёевнинг Олий Мажлисга мурожаатномаси. 2020 йил 29 декабрь // president. uz/uz/lists/view/4057

2 Қориева М. Мустақиллик - эркин ва фаровон хаёт. Т.: Шарқ, 2009. 142 б.

3 “Ёшларга оид давлат сиёсатини амалга ошириш стратегияси: мавжуд вазият ва ривожлантириш истиқболлари" мавзусидаги илмий-амалий конференцияси мақолалар тўплами.Т: “Tafakkur-Bo“stoni”. 2019. 459 б.
} 
ривожлантириб бориш ва х.к.

Шунингдек, ёшларнинг давлат ва жамият хаётида фаол иштирок этиши, ўз навбатида, жамиятимизни янада демократлаштириш, эркинлаштириш ва фуқаролик жамияти институтларини шакллантириш хамда изчил ривожлантириш билан чамбарчас боғликдир. Шу маънода, кейинги даврда ижтимоий хаётнинг барча сохаларида демократик ўзгаришларни амалга оширишда фуқаролик жамияти институтлари, хусусан, нодавлат нотижорат ташкилотларининг (ННТ) роли ва ахамияти, ижтимоий фаоллиги, умуман, улар фаолиятининг самарадорлигини кучайтиришга қаратилган мухим чора-тадбирлар қабул қилинди.

Шу ўринда айтиш жоизки, ёшларнинг давлат ва жамият ишларидаги иштироки турли институционал тузилмалар орқали амалга оширилади. Бу борада умумий тарзда, Ўзбекистонда ёшлар масаласи билан шуғулланувчи ташкилотларни умумий тарзда куйидагича ажратиш мумкин: давлат ёшлар ташкилотлари, нодавлат нотижорат ёшлар ташкилотлари, касаба уюшмалари, хотин-қизлар ташкилотлари, ўз-ўзини бошқариш ташкилотлари, болалар ташкилотлари, сиёсий партиялар таркибидаги ёшлар ташкилотлари (“ёшлар қанотлари”). Бизнингча, ёшлар билан шуғулланувчи ташкилотларнинг турлича кўринишга эгалиги жамиятда фикрлар хилма-хиллиги (плюрализм) мухитини шакллантиришга йўналтирилган.

Хулоса ўрнида таъкидлаш лозимки, давлатимиз рахбари томонидан баркамол авлод тарбияси мамлакат тақдирига дахлдор энг устувор вазифа сифатида белгиланди. Уларнинг куч ва салохиятини юрт тинчлиги, ватан тараққиёти ва халқ фаровонлиги сари сафарбар этишда давлат хокимияти ва бошқаруви органлари, нодавлат нотижорат ташкилотлари, фуқаролик жамияти бошқа институтларининг самарали хамкорлиги мухим ахамият касб этади. 


\title{
POSSIBILITIES OF USING TEACHING VIDEO LESSONS IN THE EDUCATIONAL SYSTEM
}

\author{
Sh.A.Abduraxmanova \\ Department of Information Technology at the \\ Tashkent Pedagogical University named after Nizami \\ A.A.Sultonmurodov \\ IV year student of the department «Information Technology»
}

Annotation. This article describes the application of multimedia technologies in the education system, in particular the possibilities of video lessons.

Key words: video and audio resources, instructional video lessons, interactive presentations, online platform.

Ensuring strong integration of modern information and communication technologies and educational technologies in the introduction of digital technologies and modern methods in the educational process, individualization of educational processes on the basis of digital technologies, development of distance learning services, webinars, online, "blended learning" requires the widespread introduction of flipped classroom technology.

These technologies typically consist of the following multimedia components:

- online platform for distance learning and exchange of educational materials;

- video and audio resources, texts;

- interactive presentations;

- automated test programs;

- virtual laboratories;

- online communication between professors and students [1].

PF-5812 of September 6, 2019 "On additional measures to further improve the system of vocational education" and the Concept of development of the higher education system of the Republic of Uzbekistan until 2030 of October 8, 2019 The concept of development of teaching of computer science and information technologies in preschool, general secondary, vocational and higher education systems of the Republic of Uzbekistan has been developed in accordance with the tasks set out in the Decree No. PF-5847 "On approval". The concept identifies the main trends in the development of computer science, especially multimedia education in professional and higher education systems, including:

- the content of computer education, the formation of technological literacy, critical thinking, intellectual skills and creative competencies that can be applied in independent life;

- Development of dual system training modules based on modern forms, methods and tools of informatics, in particular the organization of multimedia education;

- Introduction of digital technologies and modern methods based on multimedia technologies in the process of computer science education;

- application of information and communication technologies, in particular multimedia, in all spheres of human life and activity.

According to these trends, the use of information and communication technologies can be used to implement education through video lessons, to ensure the harmonious development of a person with information and communication skills of modern technologies and information culture, as well as to demonstrate existing experience and its helps determine the effectiveness.

A video lesson is a process of transferring knowledge using multimedia technologies. In this case, the role of the teacher is played not by a living person, but by a virtual or on-screen sound. Unlike the usual form of a lesson, a video lesson is a more fun learning process [2].

There are several programs designed to create instructional video lessons, including SmartCapture, ActivePresenter, SMRecorder, Weeny Free Video Recorder, PremierPro, Camtasia Studio, Movavi Screen Capture Studio, and Bandicam. After exploring the possibilities of these programs, first of all, Camtasia Studio, which has a popular and simple interface, was selected as the most suitable 
program for creating instructional video lessons. Camtasia Studio is designed to create video tutorials, presentations and other similar materials to be shown to observers.

One of the main features of video tutorials created in the education system is determined by certain subtleties of the study of this topic, which in turn requires a large number of visual aids, because without their participation in a variety of living world It is impossible to fully demonstrate the nebula, the need to build it, the mechanism of formation and development of biological, chemical and physical processes. If we do all this through a video lesson, we will have great conveniences.

The pedagogical and psychological features of video tutorials depend on the form and appearance of the description and expression of the teaching materials used to form knowledge and skills. They should focus not only on problem-solving and problem-solving, practical and laboratory work, but also on the formation of students knowledge, skills and abilities throughout the learning process.

One of the main didactic issues in the field of modeling and general methods of influencing the objects of imagination is one of the most important in the creation of video courses for the education system.

Thus, the form of the video lesson repeats almost all the traditional principles of a regular lesson. The only significant difference is the shape. The greatest success in transforming the classic form of video lessons is seen in independent learning. Currently, the Internet world is a "repository" of all types of video lessons.

\section{References:}

1. Hamdamov R., Begimkulov U., Taylokov N. Information technologies in education. For higher education institutions / R. Hamdamov, U. Begimkulov, N. Taylakov. UzME State Scientific Publishing House. -T .: 2010,120 p.

2. Polat E.S. New Pedagogical and Information Technologies in Educational System [Text] / E.S. Polat.-, 2008. - 272 p. 


\title{
ТИКУВ БУЮМЛАРИНИГА ИШЛОВ БЕРИШДА РЕСУРСТЕЖАМКОР ТЕХНОЛОГИЯСИ РИВОЖЛАНИШИНИНГ ЗАМОНАВИЙ ХОЛАТИ
}

Артикбаева Нозима Муминджановна

Тошкент тўқимачилик ва енгил саноат институти nozima.artikbayeva.84@bk.ru+998977194565,

\begin{abstract}
Аннотация. Мақолада ресурстежамкор технологиялар асосида тикув буюмларини ишлаб чиқаришда намлаб иситиб ишлов бериш жараёнларини такомиллаштириш бўйича маълумотлар келтирилган.
\end{abstract}

Аннотация. В статье представлена информация по совершенствованию процесса влажно тепловой обработки при производстве швейных изделий на основе ресурсосберегающих технологий.

Abstract. The article provides information on improving the process of wet heat treatment in the manufacture of garments based on resource-saving technologies.

Калит сўзлар. Материал, полотно, намлабиситиб ишлов бериш, пресс, ресурстежамкор, буғ, узел, қотирма.

Ключевые слова. Материал, полотно, влажно тепловая обработка, пресс, ресурсосберегающий, пар, узел, дублерин.

Keywords. Material, canvas, wet processing, press, resource-saving, steam, knot, hardening.

Республикамизда тикувчилик корхоналарида тайёр буюмларнинг рақобатбардошлигини таъминлаш энг долзарб вазифалардан бўлиб, у таркибий материаллар сифати, конструкцияси ва кийимни тикиш технологиясига боғлиқ. Мазкур технологик занжирда охирги йилларда тикув буюмларига намлаб иситиб ишлов бериш (НИИБ) ва узил кесил ишлов беришнинг роли ортиб, у бевосита ташқи кўриниш, истеъмолчи хусусиятлари ва махсулотнинг сифат кўрсаткичларини шаклланишига кучли таъсир қилади.

Янги режимларда буюмларга намлаб иситиб ишлов беришни бажарилиши ўз навбатида бозорда янги асбоб-ускуна ва технологик воситаларни ишлаб чиқилиши ва пайдо бўлишини талаб қилди.

Бироқ охирги пайтда кийимни лойихалаш ва тайёрлаш билан боғлиқ масаларни ечишга доир умуман янги ёндашувлар ёритилган кўплаб ишлар пайдо бўлмоқда. Мазкур ишларнинг асосида матони ва тикув буюмини тайёрлаш жараёнини узилмас ягона технологик жараёнга айлантиришнинг тамойиллари ётади [1].

Бу каби технология матони тайёрлаш, бичиш ва тикиш жараёнларидан холи бўлган тарзда кийим тайёрлаш жараёнини автоматлаштириш ва ишлаб чиқариш чиқиндиларини сезиларли даражада камайтириш имконини беради. Биринчи галда бу яхлит тўқилган кийим деталларини ишлаб чиқарилиши кенгаяётган тикув-трикотаж саноатига тегишлидир.

Толалар ва полимер материаллардан яхлит шакл хосил қилинган буюмларни, кийимнинг яхлит тўқилган деталларини тайёрлаш буйича алохида натижалар мавжуд.

Саноатда тикув буюмларига узил кесил ишлов бериш методлари буғ хаво манекенларида амалга оширилади. Тикув буюмларини шаклини бир жараёнда хосил қилиш технологияси хамда вибро шакл бериш методларини қўллаш асосида шакл хосил қилиш ва қотирмали материални ёпиштириш операцияларини бирлаштириш сохасида хам тадқиқотлар олиб борилмоқда.

1960-йиллардан бошлабтикувчилик тармоғида матоларнинг харакатчан тўрлитузилмасининг хусусиятларини хисобга олган холда кийимни конструкциялаш ва тайёрлашнинг янги илмий йўналиши шаклланади. Унинг асосчиси буюк рус математик академиги П.Л.Чебышев, илк бор эгри юзаларни тўрли тузилмага эга материаллардан қобиқлар билан кийинтириш мумкинлиги ғояси илгари сурган [1].

Олиб борилган тадқиқотларнинг натижаси сифатида янги иқтисодий тежамкор конструкциялаш ва кийимнинг яхлит бичилган деталларининг технологик конструкцияларини олишнинг методлари яратилган.

Қатор муаллифлар томонидан [1] кийимнинг яхлит бичилган деталлари ва узелларини конструкциялаш методлари, тайёрлаш технологияси ва шакл бериш асбоб-ускуналари ишлаб чиқилган. Бу ресурстежамкор технология бўйича кийим тайёрлашжараёнини такомиллаштириш ва автоматлаштиришга тикув буюмларига ишлов бериш ва йиғиш сермехнатлигини камайтириш 
орқали буюмларнинг материал хажмдорлигини камайтиришга имкон берди.

Кийим тайёрлаш усуллари бўйича олиб борилган тахлил асосида янги технологиялар ва асбоб-ускуналарни ишлаб чиқиш билан бирга тикувчилик тармоғини риожлантиришнинг асосий йўналишлари аниқлаштириб олинди. Истиқболли технология асосига кийимнинг яхлит бичилган деталлари ва буюм узелларини тайёрлашда қўлланиладиган тўқима материалларнинг шакл хосил қилиш хусусиятларидан самарали фойдаланиш қўйилганлиги билан у материал хажмдорлиги ва сермехнатлигини сезиларли тарзда камайтириш орқали мехнат унумдорлиги ва чиқарилаётган махсулот сифатини оширишни таъминлайди [2].

\section{Фойдаланилган адабиётлар рўйхати.}

1. С.Ш.Ташпулатов Разработка высокоэффективной ресурсосберегающей технологии изготовления швейных изделий: Автореф.дис...докт.техн.наук-Тошкент: ТИТЛП. 2008-38б.

2. Артикбаева Н.М., Шин И.Г., Ташпулатов С.Ш., Черунова И.В., Бралина Н. Оценка напряженного состояния при формообразовании объемных участков деталей одежды потоком сжатого воздуха. Журнал Технология текстильной промышленности. №5-2019, Б-181-187. 


\section{КОНСТРУКТОРСКО ТЕХНОЛОГИЧЕСКИ Е МЕТОДЫ ПОВЫШЕНИЯ РАБОТОСПОСОБНОСТИ ДВИГАТЕЛЕЙ}

Кодиров Ф.К. (магистрант), Кенжаев С.Н. (ассистент) Научный руководитель: доц. Убайдуллаев Г.К.

Тема повышения работоспособности машин и механизмов в последнее время приобретает большую актуальность. Практически во всех технически развитых странах на разработку способов и технологий повышающих надежности подвижных соединений и снижение их интенсивности изнашивания уделяется повышенное внимание.

Недостаточная работоспособность деталей машин в первую очередь объясняется ужесточением эксплуатационных режимов машин, отсутствием обоснованных и подтвержденных объективных критериев, и методик выбора материалов (как конструкционных, так и смазочных), защитных покрытий и способов обработки для конкретных деталей трибосоединений работающих в соответствующих условиях. При этом за счёт повышения качества исполнения взаимодействующих поверхностей пар трения деталей и подбора рациональных их материалов и эксплуатационных режимов машин в целом можно значительно повысить их ресурс.

Известно, что работоспособность двигателя в целом зависит от износостойкости отдельных составляющих его элементов. Для решения задачи увеличения работоспособности двигателей необходимо найти способы увеличения ресурса их соединений.

Низкий ресурс двигателей приводит к издержкам от простоя тракторов и машин. Ряд авторов объясняют это недостатками технологий изготовления и применением некачественных материалов [1].

На современной технике различного назначения наиболее часто применяют четырехтактные дизели различных конструкций. Бензиновые двигатели в грузовые машины в качестве силовых установок распространены гораздо реже.

Основными трибосопряжениями, являющиеся определяющими для ресурсных показателей двигателей, работающих в условиях трения скольжения, считаются сопряжения «гильза цилиндра - поршневое кольцо» и «коленчатый вал - вкладыш», которые обеспечивать 70\% ресурса двигателей в целом [1]. При этом назначение поршневых колец является уплотнение камеры сгорания и удаление излишков смазочного материала с зеркала гильзы. При больших значениях износов в паре трения «гильза цилиндра - поршневое кольцо» повышается прорыв газов в картер и расход масла.

Несмотря на плотное прижатие поршневых колец к стенкам гильзы цилиндра вследствие действия сил упругости и давления газов в процессе работы двигателя, между кольцом и гильзой сохраняется масляная пленка толщиной около 10 мкм, препятствующая сухому трение указанных деталей.

Материалами для изготовления гильз цилиндров ДВС как правило служат специальный или серый чугуны. В целях повышения износостойкости поверхностей трения гильз цилиндров и поршневых колец они подвергаются термообработке или покрывают износостойкими покрытиями. Так, например, нанесение хрома на поверхность зеркала цилиндра может в несколько раз повысить его износостойкость. Тем не менее, на практике хромированию, как правило, подвергают только поршневые кольца. Это связано в первую очередь с низкими триботехническими характеристиками пары трения «хром - хром».

Повышение ресурса двигателей возможно путём реализации конструкторских, технологических и эксплуатационных мероприятий

К эксплуатационным мероприятиям относят использование смазочных масел с присадками в начальный период эксплуатации, а также выбор режимов работы двигателя.

К конструкторским мероприятиям можно отнести: выбор материалов пар трения; создание условий для реализации гидродинамического режима смазки; применение геометрической формы деталей, обеспечивающей требуемую механику контакта; поддержание оптимальных температурных режимов в узлах трения и т.д. В настоящее время в данном направлении выполнен ряд важных исследований, приведших к практическим результатам. Так, например, установлено, что при нормальных условиях работы двигателя большинство поршневых колец 
образуют бочкообразный профиль, обеспечивающий условия гидродинамической смазки. Испытания колец с искусственно закруглённой образующей показали, что их износ до 10 раз меньше износа обычных колец [2].

Повышения маслоудерживающей способности и сопротивляемости задиру гильз цилиндров возможно добиться нанесением маслоудерживающего рельефа в виде лунок или канавок вибронакаткой, плосковершинным хонингованием, что обеспечивает увеличение ресурса гильз до 30\%. Широкое распространение для предупреждения задиров получили покрытия колец, наносимые химическим и электрохимическим способами: лужение, кадмирование, меднение, фосфотирование, сульфидирование, железнение, пористое хромирование и т.д. Положительным свойством сульфидных покрытий является их способность при трении и износе выделять серу, которая содействует скольжению и предотвращает задиры в условиях граничного трения. Получили распространение молибденовые покрытия на поршневых кольцах, показавшие хорошие противозадирные и износостойкие качества [2].

К технологическим мероприятиям относят как повышение точности изготовления и сборки деталей трибосопряжений, так и применение более совершенных способов обработки поверхностей трения. Во втором случае для повышения ресурса гильз цилиндров применяют специальные методы хонингования: плосковершинное, антифрикционно - деформационное и без абразивное. Припомощи антифрикционно - деформационного хонингования на поверхности трения получают прочное антифрикционное покрытие из дисульфида молибдена, графита, меди, олова [3]. Подобные методы получили называние «Финишная антифрикционная без абразивная обработка» - ФАБО.

Процесс ФАБО заключается в покрытии поверхности трения деталей тонким (до 7 мкм) слоем твердосмазочного материала, придающего им антифрикционные и противоизносные свойства и повышающего контактную жесткость. Поверхности деталей при фрикционномеханическом способе ФАБО обрабатывают как правило инструментом из твердосмазочных материалов с использованием технологических сред, содержащих ПАВ. Структура покрытия, полученного подобным образом, пористая, что способствует удержанию смазочного материала на контактирующих поверхностях.

ФАБО дает возможность повысить износостойкость зеркала гильзы до 2 раз, сократить время приработки, устранить задиры, увеличить ресурс двигателя. Процесс ФАБО не только придает элементам пар трения антифрикционные свойства, но и защищает обработанные поверхности от проникновения водорода, уменьшая водородное изнашивание.

Методы ФАБО не только эффективны для повышения износостойкости поверхностей деталей, но и не требуют применения дополнительного оборудования, то есть практически не увеличивают трудоемкость и себестоимость изготовления двигателей, что облегчает их внедрение в производство.

\section{Список литературы}

1. Соловьев, А.В. Повышение качества и экономичности обкатки отремонтированных двигателей ЗИЛ-130 с использованием приработочных технологических жидкостей.: дис. ... канд. техн. наук:. - М., 2001. - 244 с.

2. Стрельцов В. В. Трибологические основы повышения ресурса машин: / В. В. Стрельцов, А. М. Приходько, и др. - М.: ФГОУ ВПО МГАУ, 2010. - 168 с.

3. Карпенков В. Ф. Финишная антифрикционная без абразивная обработка (ФАБО) деталей / В. Ф. Карпенков, В. В. Стрельцов, И. Л. Приходько и др. - Пущино: ОНТИ ПНЦ PAH, 1996. - 108 c. 


\title{
АНАЛИЗ ФОРМИРОВАНИЯ ПОГРЕШНОСТИ ФОРМЫ ДЕТАЛИ В ПРОЦЕССЕ ОБРАБОТКИ
}

\author{
Убайдуллаев Ғ., Қодиров Ф. \\ (ТГТУ)
}

В процес $\neg$ се механической обработки происходит приближение геометричческого подобия заготовки к указанным в чертежах формам и размерам детали. Одновременно обработкой вносятся свои искажения, в том числе при установке и закреплении заготовки на стан-

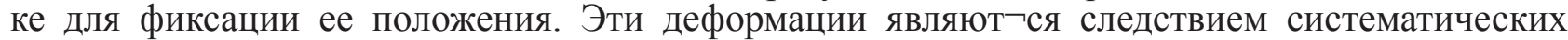
и случайных погрешностей; их величина и характер зависят от вида и материала заготовки, способа приложения зажимных усилий и их величины, а также от жесткости элементов станка и приспособления. На заготовках следует различать поверхности: обрабатываемые; ориентируюᄀщие заготовку относительно инструмента или рабочих элементов станка; воспринимающие усилия зажимных устройств; исполь ᄀзуемые как база для измерений, свобод-

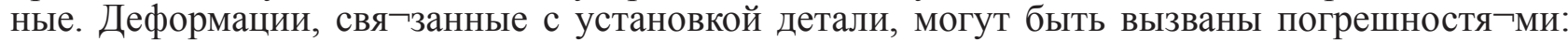
размеров и формы установочных элементов детали; выпол ᄀнения установочных элементов приспособлений; базирования. Следует придерживаться принципа совмещения установочной, измерительной и сборочной баз; соблюдать постоянство баз для всех операций; обеспечивать жесткость установки заготовки, т. е. неизменность ее положения в процессе обработки. Если конфигурация детали не дает возможности выбрать базу, при-бегают к обработке установочных поверхностей, так называемых искусственных баз. Таковыми являются центровые гнезда для обработки деталей класса валов, площадки и отверстия при об-работке моноблоков цилиндров двигателей автомобилей, выточᄀки в юбках поршней и т. д. В связи с отклонениями базирующих поверхностей от правильных геометрических форм, особенно у черных и грубо обработанных заготовок, целесообразно их устанавливать на точечные опоры[1].

В местах касания заготовки с установленными элементами приспособлений на опоры со сферическими и рифлеными голов ᄀками контактные деформации могут достигнуть величи-

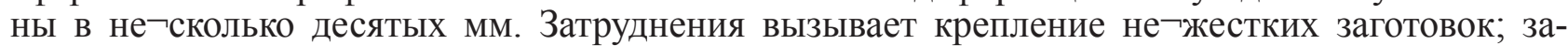
данная форма, взаимное расположение поверхностей и размеры их относительно легко под-

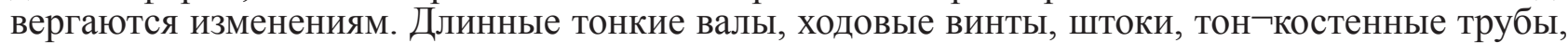
гильзы, цилиндры и многие другие заготовки относятся к группе нежестких деталей. Ввиду значительных деформаций тонкостенных полых заготовок часто приходится отказываться от кулачковых и цанговых патронов и крепить такие заготовки по торцам. Однако и при таком

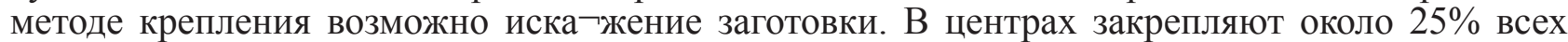
детаᄀлей, обрабатываемых на токарных станках. Несовпадение оси зацентровки с геометрической осью влечет за собой увеличение припуска на обработку, неравномерность глубины и усилия ре ᄀзания. Центровое отверстие обрабатывают разными способами.

Деформация тонкостенных цилин-дров, сжатых двумя равными диаметральными силами, прило ᄀженными близко к торцу, встречается при закреплении круговых полых цилиндров в двухкулачковых патронах по наружной по $\neg$ верхности и в ряде конструкций машин, в частности, при креп-лении гильз цилиндров. Были исследованы тонкостенные гладкие трубы с внешним диаметром $\mathrm{D}=40,150 \mathrm{мм}$, длиной $\mathrm{L}=30,1000$ мм, толщиной стенки $\alpha=0,75,3$ мм. В зависимости от размеров трубы нагрузка составляла от 200 до $2000 \mathrm{H}$.

При изготовлении и ремонта деталей, сборке механизмов, а также в процессе их эксплуатации происходят искажения формы и размеров звеньев, изменяется характер сопряжения, возникает деформация деталей, которые изменяют динамические свойства механизмов и заметно влияют на точность и надежность выполнения механизмами заданных функций.

Качество рабочих поверхностей деталей двигателей и их геометрические и физико-механические параметры, а также зазоры в сопряжениях оказывают непосредственное влияние на надежность узлов и двигателя в целом.

Применение блока с легкосъемными «мокрыми» гильзами способствует не только снижению тепловой напряженности и интенсивности износа деталей цилиндропоршневая группа, но и позволяет решать ряд конструктивно-технологических и эксплуатационных задач. К ним можно отнести повышение технологичности изготовления блока цилиндров, возможность изготовления гильз из более качественных материалов.

Искажение макрогеометрии цилиндров наблюдается во всех двигателях. Специфика конструкции двигателя и схемы передачи в нем усилий существенно влияют на численное значение и характер деформации цилиндров, ориентацию искажений по их высоте и периметру.

Установлено, что одной из основных причин искажения формы цилиндровых гильз с неризистовыми вставками является их относительно низкая жесткость по сравнению с моно 
гильзами. Поэтому можно рекомендовать их замены моно гильзами из износостойких материалов или из чугуна с хромированными рабочими поверхностями. Вместе с этим следует отметить, что в хромированных гильзах на стадии приработки повышается вероятность появления задирав на их поверхностях.

Исследованием влияния затяжки гаек на шпильках и болтах головки блока с минимальными и максимальными усилиями в пределах технических условии установлено, что различий в деформациях нет. Вместе с тем установлено влияние степени затяжки на деформации гильзы, когда она выступает над плоскостью блока цилиндров. На основание полученных результатов рекомендуется ограничить величины этого параметра допуском 0,02-0,05 мм. Исследованиями также установлено, что деформации гильзы возрастают при увеличении биения посадочных плоскостей и посадочного гнезда в блоке и при уменьшении монтажного зазора гильзы в блоке цилиндров.Установлено, что увеличение зазора по верхнему пояску более 0,17 мм приводит к резкому усилению колебаний гильзы, что, в свою очередь, интенсифицирует износ деталей ЦПГ.

На авторемонтных заводах наибольшее применение получили как способы устранения этого дефекта, расточка нижнего посадочного пояска под ремонтный размер и установка ремонтной детали-втулки.

Наиболее эффективным способом восстановления этой поверхности нанесение на нее полимерной композиции и установку калибрующей оправки для формирования правильной геометрической формы посадочного пояска в процессе затвердевания композиции.

Исследование механизма возникновения макрогеометрических отклонений и разработка конструктивно- технологических методов их устранения для блоков со вставными гильзами сложнее, чем для моноблоков.

Несмотря на эти сложности, возникшие с применением блоков со вставными гильзами, такая конструкция блоков в настоящее время нашла широкое применение в мировом двигателестроении.

В двигателях с повышенной долговечностью часто применяются блоки с легкосъемными «мокрыми» гильзами. В нашей стране в основном выпускают двигатели с блоками такой конструкции.

Искажение рабочей поверхности цилиндров при изготовлении деталей может быть также результатом несоблюдения режимов старения и нарушения режимов механической обработки.

Результаты экспериментальных исследований показывают, что на характер и величину деформации цилиндра в процессе монтажа, а в последующей эксплуатации на стуки и задиры цилиндров существенно влияет операция завинчивания шпилек и болтов в блок, затяжка и порядок затяжки крепящих деталей, а также конструкции и материал прокладки, устанавливаемой между блоком и головкой.

Исследуя деформации цилиндров, при сборке установлено, что если деформация в процессе сборки образуется в результате случайного сочетания размеров сопрягаемых деталей, тогда искажение геометрической формы цилиндров нужно устранять технологическими средствами. Эта задача должна решаться на этапе конструирования, если макрогеометрические отклонения цилиндра имеют определенные закономерности.

Результаты исследований показывают, что численные значения искажения формы цилиндров при сборке зависят от комплекса случайных и закономерных факторов, как конструктивных, так и технологических, а характер деформаций определяется конструкцией двигателя.

В практике двигателестроения применяются также блоки с сухими гильзами. По сравнению с мокрыми гильзами, сухие гильзы более склонны к монтажным деформациям. Кроме того, сухие гильзы не обеспечивают равномерного отвода тепла в блок, так как между ними образуются местные тепловые сопротивления, что также способствует местной деформации.

\section{Использованная литература}

1. Проников А.С. Параметрическая надежность машин. - М.: изд. МГТУ им. Баумана, 2002. 548c. 


\title{
СИСТЕМА УРАВНЕНИЙ ДВУХСКОРОСТНОЙ ГИДРОДИНАМИКИ БЕЗ ДАВЛЕНИЯ
}

\author{
Х. Имомназаров ${ }^{1}$, А. Омонов ${ }^{2}$. \\ ${ }^{1}$ Учреждение Российской академии наук Институт \\ вычислительной математики и математической \\ геофизики СО РАН, Новосибирск, \\ ${ }^{2}$ Каршинский государственный университет.
}

Аннотация. Рассмотрена задача Коши для одномерной системы уравнений типа Бюргерса. Получена формула для ее решения в виде системы нелинейных уравнений Вольтрерра второго рода. Показано, что при исчезновении коэффициента межфазного трения, построенные решения для каждой из подсистем переходят к известному решению задачи Коши для уравнения Бюргерса.

Ключевые слова. Систему уравнений типа Бюргерса, коэффициента Дарси, двухскоростной гидродинамики, задача Коши, уравнений НавьеСтокса.

Одномерным аналогом уравнений Навье-Стокса для сжимаемых жидкостей можно считать систему уравнений типа Бюргерса, которая представляет собой систему нелинейных уравнений конвекции-диффузии [101-104]

$$
\begin{aligned}
& u_{t}+u u_{x}=v u_{x x}-\tilde{b}(u-v), \\
& v_{t}+v v_{x}=\tilde{v} v_{x x}+b(u-v),
\end{aligned}
$$

где величины $u$ и $v$ можно рассматривать, как скорости подсистем с размерностью, составляющих двухскоростной континуум с соответствующими парциальными плотностями $\rho_{1}$ и $\rho_{2}, \rho=\rho_{1}+\rho_{2}$ - общая плотность континуума, $\tilde{b}=\frac{\rho_{2}}{\rho_{1}} b, b$-коэффициент межкомпонентного трения, который является аналогом коэффициента Дарси для пористых сред. Положительные константы $v$ и $v$ играют роль кинематических вязкостей подсистем. Система (1), (2) от системы уравнений двухскоростной гидродинамики в диссипативном приближении отсутствием давления и условиями не сжимаемости. Поэтому следуя систему (1), (2) мы иногда будем называть двухскоростной гидродинамикой без давления.

Рассмотрим для системы (1), (2) в полосе $\Gamma_{[0, T]}=\{(t, x): 0 \leq t \leq$ $T,-\infty<x<\infty\}$ задачу Коши со следующими начальными данными

$$
\begin{array}{ll}
\left.u\right|_{t=0}=u_{0}(x), & -\infty<x<\infty \\
\left.v\right|_{t=0}=v_{0}(x), & -\infty<x<\infty
\end{array}
$$

Нас будут интересовать гладкие решения задачи Коши для системы уравнений типа Бюргерса (1), (2). При этом считаем, что начальные данные $u_{0}(x), v_{0}(x)$ считаются бесконечно дифференцируемые с компактными носителями. 
Удобно сделать замену переменных Флорина-Хопфа-Коула

$$
\varphi=\operatorname{Exp}\left[-\frac{1}{2 v} \int u d x\right], \psi=\operatorname{Exp}\left[-\frac{1}{2 \widetilde{v}} \int v d x\right] .
$$

При этом функции $u$ и $v$ выражаются через функции $\varphi$ и $\psi$ по формулам

$$
u=-2 v \frac{\varphi_{x}}{\varphi}, v=-2 \widetilde{v} \frac{\psi_{x}}{\psi} .
$$

В терминах функции $\varphi$ и $\psi$ система динамических уравнений (1) и (2) примет вид

$$
\left(\frac{\varphi_{t}}{\varphi}\right)_{x}=\left(v \frac{\varphi_{x x}}{\varphi}\right)_{x}-\frac{\tilde{b}}{v}\left(\ln \frac{\varphi^{v}}{\psi^{\tilde{v}}}\right)_{x},\left(\frac{\psi_{t}}{\psi}\right)_{x}=\left(\tilde{v} \frac{\psi_{x x}}{\psi}\right)_{x}+\frac{b}{\widetilde{v}}\left(\ln \frac{\varphi^{v}}{\psi^{\tilde{v}}}\right)_{x}
$$

Решения задачи Коши для данной системы с данными

$$
\begin{gathered}
\left.\varphi\right|_{t=0}=\varphi_{0}(x), \quad-\infty<x<\infty \\
\left.\psi\right|_{t=0}=\psi_{0}(x), \quad-\infty<x<\infty
\end{gathered}
$$

имеют вид

$$
\begin{gathered}
\varphi(t, x)=\int_{-\infty}^{\infty} G^{v}(x, \xi, t) \varphi_{0}(\xi) d \xi \\
-\frac{\tilde{b}}{v} \int_{0}^{t} \int_{-\infty}^{\infty} G^{v}(x, \xi, t-\tau) \varphi(\xi, \tau)(v \ln \varphi(\xi, \tau)--\tilde{v} \ln \psi(\xi, \tau)) d \xi d \tau, \\
\psi(t, x)=\int_{-\infty}^{\infty} G^{\widetilde{v}}(x, \xi, t) \psi_{0}(\xi) d \xi \\
+\frac{b}{\tilde{v}} \int_{0}^{t} \int_{-\infty}^{\infty} G^{\widetilde{v}}(x, \xi, t-\tau) \psi(\xi, \tau)(v \ln \varphi(\xi, \tau)-\tilde{v} \ln \psi(\xi, \tau)) d \xi d \tau
\end{gathered}
$$

где $G^{v}(x, \xi, t)$-есть фундаментальное решение одномерного уравнения диффузии с коэффициентом теплопроводностью $v$.

Тогда для решения задачи Коши (1)-(4) справедливы формулы

$$
u(t, x)=\frac{\int_{-\infty}^{\infty} \frac{x-\xi}{t} \operatorname{Exp}\left[-\frac{1}{2 v} F\left(u_{0}(\xi), x, \xi, t\right)\right] d \xi}{\int_{-\infty}^{\infty} \operatorname{Exp}\left[-\frac{1}{2 v} F\left(u_{0}(\xi), x, \xi, t\right)\right] d \xi}-
$$




$$
\begin{gathered}
-\frac{\int_{0}^{t} \int_{-\infty}^{\infty} \sqrt{1+\frac{\tau}{t-\tau}}\left(u(t, x)-\frac{x-\xi}{t-\tau}\right) F_{2}(u, v, x, \xi, t, \tau) d \xi d \tau}{\int_{-\infty}^{\infty} \operatorname{Exp}\left[-\frac{1}{2 v} F\left(u_{0}(\xi), x, \xi, t\right)\right] d \xi}, \\
v(t, x)=\frac{\int_{-\infty}^{\infty} \frac{x-\xi}{t} \operatorname{Exp}\left[-\frac{1}{2 \widetilde{v}} F\left(v_{0}(\xi), x, \xi, t\right)\right] d \xi}{\int_{-\infty}^{\infty} \operatorname{Exp}\left[-\frac{1}{2 \widetilde{v}} F\left(v_{0}(\xi), x, \xi, t\right)\right] d \xi}- \\
-\frac{\int_{0}^{t} \int_{-\infty}^{\infty} \sqrt{1+\frac{\tau}{t-\tau}}\left(v(t, x)-\frac{x-\xi}{t-\tau}\right) G_{2}(u, v, x, \xi, t, \tau) d \xi d \tau}{\int_{-\infty}^{\infty} \operatorname{Exp}\left[-\frac{1}{2 \widetilde{v}} F\left(v_{0}(\xi), x, \xi, t\right)\right] d \xi}
\end{gathered}
$$

где функции $F, F_{2}$ и $G_{2}$ определены по следующими формулами

$$
\begin{gathered}
F_{2}(u, v, x, \xi, t, \tau)= \\
\frac{\tilde{b}}{2 v}\left\{F_{1}(u, x, \xi, t, \tau)-F_{1}(v, x, \xi, t, \tau)\right\} \operatorname{Exp}\left[-\frac{1}{2 v} F_{1}(u, x, \xi, t, \tau)\right], \\
G_{2}(u, v, x, \xi, t, \tau)= \\
\frac{b}{2 \widetilde{v}}\left\{F_{1}(v, x, \xi, t, \tau)-F_{1}(u, x, \xi, t, \tau)\right\} \operatorname{Exp}\left[-\frac{1}{2 \widetilde{v}} F_{1}(u, x, \xi, t, \tau)\right], \\
F_{1}(u, x, y, t, \tau)=\frac{(x-y)^{2}}{2(t-\tau)}+\int_{-\infty}^{y} u(\tau, \eta) d \eta \\
F(u, x, y, t)=\frac{(x-y)^{2}}{2 t}+\int_{-\infty}^{y} u(t, \eta) d \eta .
\end{gathered}
$$

Замечание. При исчезновении коэффициента трения $b$ (в отсутствии диссипации энергии, обусловленной коэффициентом трения формулы (5), (6) переходит к известному решению задачи Коши для уравнения Бюргерса.

\section{Литература}

1. Нигматуллин Р. И. Динамика Многоскоростных Сред: В 2-х т. М.: Наука, 1987. -Т.1, -464c.; Т2. -360с.

2. Blokhin A.M., Dorovsky V.N. Mathematical modelling in the theory of multivelocity continuum. -New York: Nova Science, 1995, 192p.

3. Жабборов Н.M., Имомназаров Х.Х. Некоторые начально-краевые задачи механики двухскоростных сред. Ташкент, 2012. 212 с.

4. Васильев Г.С., Имомназаров Х.Х., Мамасолиев Б.Ж., Султанов М.А. Об одной системе уравнений типа Бюргерса, возникающей в двухскоростной гидродинамики // Доклады АН РУз, 2016, № 5, С.3-7. 
SCIENTIFIC PUBLISHING CENTER VIRTUALCONFERENCES.PRESS

INTERNATIONAL CONFERENCE SCIENCE AND EDUCATION/ULUSLARARASI KONFERANS BILIM VE EĞITIM

APRIL 2021

ANTALYA, TURKEY 